\title{
Peningkatan Peran Mediator Dalam Kepastian Penyelesaian Sengketa Dan Konflik Pertanahan
}

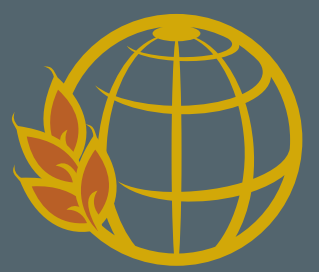

PUSAT PENELITIAN DAN PENGEMBANGAN

BADAN PERTANAHAN NASIONAL REPUBLIK INDONESIA 2013 
Perpustakaan Nasional : Katalog Dalam Terbitan (KDT)

Peningkatan Peran Mediator Dalam Kepastian Penyelesaian

Sengketa Dan Konflik Pertanahan

Trie Sakti, 2013

$\mathrm{viii}+118 \mathrm{hlm} ; 15,5 \times 24 \mathrm{~cm}$

\title{
Copyright (C) 2013 pada penulis
}

Hak cipta dilindungi Undang-Undang. Dilarang memperbanyak atau memindahkan sebagian atau seluruh isi buku ini dalam bentuk apapun, baik secara elektronis maupun mekanis, termasuk memfotocopy, merekam atau dengan sistem penyimpanan lainnya, tanpa izin tertulis dari Penulis dan Penerbit

\section{Trie Sakti}

\author{
Editor : Rahman Yuliardhi, SH., M.Hum \\ Desain Cover dan Layout : Shofiatul Munawaroh, S.Kom \\ Cetakan Pertama : Desember 2013
}

\section{Diterbitkan Oleh:}

Pusat Penelitian dan Pengembangan

Badan Pertanahan Nasional RI

J. H. Agus Salim No.58

Jakarta Pusat

ISBN: 978-979-1069-30-4 


\section{Kata \\ Pengantar}

\author{
Frekwensi sengketa dan \\ konflik pertanahan cenderung \\ meningkat dari tahun ke \\ tahun, yang merupakan \\ akumulasi dari sisa kasus \\ tahun sebelumnya dan kasus \\ yang baru.
}

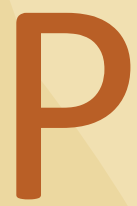

uji dan Syukur dipanjatkan kepada

ALLAH SWT atas tersusunnya Laporan Akhir Penelitian Peran Mediator Dalam Kepastian Penyelesaian Sengketa dan Konflik Pertanahan, yang merupakan penelitian yang dilaksanakan secara swakelola oleh PUSLITBANG BPN RI pada tahun anggaran 2013.

Frekwensi sengketa dan konflik pertanahan cenderung meningkat dari tahun ke tahun, baik merupakan akumulasi dari sisa kasus tahun sebelumnya maupun kasus yang baru. Kondisi ini terjadi karena sistem peradilan di Indonesia yang memungkinkan sengketa di gugat baik secara perdata, TUN dan bahkan pidana sehingga prosesnya memakan waktu lama belasan hingga puluhan tahun. Oleh karenanya, setiap terjadi sengketa dan konflik pertanahan diupayakan untuk diselesaikan melalui mediasi dengan mengedepankan terjadinya perdamaian secara win-win solution.

Hasil penelitian mendeskripsikan pelaksanaan mediasi di beberapa lokasi penelitian, dimana pelaksanaannya menuntut kecakapan aparat BPN sebagai mediator untuk mendamaikan para pihak yang bersengketa sehingga tercapai kesepakatan yang dituangkan dalam suatu Berita Acara Kesepakatan atau Perdamaian. Hanya saja kesepakatan yang sudah ditanda tangani oleh para pihak seringkali diingkari oleh mereka sendiri, walaupun dalam KUHPerdata ada ketentuan bahwa kesepakatan berlaku sebagai undang-undang bagi mereka yang bersepakat. Fenomena terjadinya pelanggaran terhadap perdamaian perlu diatur dalam suatu perundangundangan agar mempunyai kekuatan yang lebih mengikat dan dapat segera dieksekusi.

Diharapkan hasil penelitian ini dapat memberikan manfaat dalam penyusunan kebijakan di bidang pertanahan. Penulis mohon masukan untuk penyempurnaan laporan ini. Terima kasih,

Jakarta, November 2013 


\section{Daftar Isi}

\section{HALAMAN JUDUL \\ KATA PENGANTAR \\ DAFTAR ISI \\ DAFTAR TABEL DAN GAMBAR \\ BAB I PENDAHULUAN \\ 1.1. Latar Belakang \\ 1.2. Permasalahan \\ 1.3. Tujuan \\ 1.4. Hasil penelitian (output) \\ 1.5. Kegunaan Penelitian}

\section{BAB II TINJAUAN PUSTAKA}

2.1. Kerangka Teori

2.1.1. Alternative Dispute Resolution

2.1.2. Dasar Hukum Mediasi

2.1.3. Ciri- ciri Mediasi

2.1.4. Jenis Mediasi

2.1.5. Tipe Mediator

2.2. Tahapan Penanganan

Masalah Pertanahan

2.3. Kekuatan hukum dari perjanjian

2.3.1. Pengertian Perjanjian

Dan Pengaturannya

2.3.2. Syarat Sahnya Perjanjian

2.3.3. Unsur-Unsur Dalam Perjanjian

2.3.4. Pelaksanaan Perjanjian

2.3.5. Asas-asas perjanjian

2.3.6. "Syarat Batal" Perjanjian

2.3.7. Dading

2.3.8. Eksekusi Grosse Akta

2.4. Kerangka Pemikiran

\section{BAB III METODE PENELITIAN}

3.1. Tipe Penelitian

3.2. Lokasi Penelitian

3.3. Responden/Informan Penelitian

3.4. Jenis Data

3.5. Analisa Data

\section{i}

iii

iv

2$$
6
$$$$
7
$$$$
\begin{aligned}
& 7 \\
& 7
\end{aligned}
$$

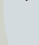

\section{9}

10

12

\section{BAB IV GAMBARAN UMUM} WILAYAH PENELITIAN

4.1. Provinsi Maluku 38

4.1.1. Karakteristik Wilayah 39

4.1.2. Pemilikan/Penguasaan Tanah 44

4.1.3. Profil Kasus Pertanahan 44

4.2. Provinsi Lampung 49

4.2.1. Karakteristik Wilayah 49

4.2.2. Struktur Pemerintahan dan Masyarakat $\quad 49$

4.2.3. Pemilikan/Penguasaan Tanah 55

4.2.4. Profil Kasus Pertanahan 56

4.3. Provinsi Kalimantan Selatan 59

4.3.1. Karakteristik Wilayah 59

4.3.2. Pemilikan/Penguasaan tanah 64

4.3.3. Profil Kasus Pertanahan 65

4.4. Provinsi Jawa Barat 70

4.4.1. Karakteristik Wilayah $\quad 70$

4.4.2. Pemilikan/Penguasaan Tanah 72

4.4.3. Profil Kasus Pertanahan 74

4.5. Provinsi Nusa Tenggara Barat 78

4.5.1. Karakteristik Wilayah 78

4.5.2. Pemilikan/Penguasaan Tanah 80

4.5.3. Profil Kasus Pertanahan 82

4.6. Dokumentasi Penelitian 87

\section{BAB V PEMBAHASAN 91}

5.1. Profil Kasus Pertanahan 92

5.2. Pengaturan penyelesaian masalah pertanahan melalui mediasi $\quad 94$

5.3. Peningkatan peran mediator dalam percepatan penyelesaian sengketa dan konflik pertanahan

5.4. Kepastian hukum terhadap hal hal yang disepakati para pihak dalam proses mediasi

BAB VI KESIMPULAN 115

6.1. Kesimpulan 116

6.2. Rekomendasi 117

DAFTAR PUSTAKA 118 


\section{Daftar Tabel}

\section{A. TABEL}

Tabel 1. Tipologi masalah pertanahan 3

Tabel 4.1. Kabupaten dan Kota di Provinsi Maluku 37

Tabel 4.2. Tipologi Masalah Provinsi Maluku 43

Tabel 4.3. Tipologi Kasus Pertanahan hasil RDP 44

Tabel 4.4. Frekwensi Kasus Pertanahan dan Penyelesaiannya 44

Tabel 4.5. Aspek yang diteliti dalam penelitian mengenai akar masalah 45

Tabel 4.6. Tim Khusus Penyelesaian Kasus Pertanahan 45

Tabel 4.7. Eksekusi Berita acara Tim penyelesaian Kasus 46

Tabel 4.8. Peta/data sebaran sengketa/konflik 46

Tabel 4.9. Kabupaten/Kota di Provinsi Lampung 48

Tabel 4.10. Pembagian Marga di Provinsi Lampung 49

Tabel 4.11. Rekapitulasi Data Sengketa, Konflik, Dan Perkara Pertanahan Tahun 2006 s/d 2012 Pada Kanwil BPN Provinsi Lampung 55

Tabel 4.12. Aspek yang diteliti dalam penelitian mengenai akar masalah

Tabel 4.13. Tim Khusus Penyelesaian Kasus Pertanahan 56

Tabel 4.14. Eksekusi Berita acara Tim penyelesaian Kasus 56

Tabel 4.15. Peta/data sebaran sengketa/konflik 57

Tabel 4.16. Daftar Kota dan kabupaten di Provinsi Kalimantan Selatan 58

Tabel 4.17. Tipologi Masalah Pertanahan Tahun 2010

Tabel 4.18. Aspek yang diteliti dalam penelitian mengenai akar masalah 65

Tabel 4.19. Tim Khusus Penyelesaian Permasalahan Pertanahan 66

Tabel 4.20. Eksekusi Berita acara Tim penyelesaian Kasus 67

Tabel 4.21. Peta/data sebaran sengketa/konflik 67

Tabel 4.22. Kabupaten dan Kota di Provinsi Jawa Barat $\quad 69$

Tabel 4.23. Tipologi Masalah Pertanahan $\quad 73$

Tabel 4.24. Tipologi Kasus Pertanahan hasil RDP 73

Tabel 4.25. Frekwensi kasus Pertanahan dan penyelesaiannya 73

Tabel 4.26. Aspek yang diteliti dalam penelitian mengenai akar masalah 74

Tabel 4.27. Tim Khusus Penyelesaian Kasus Pertanahan 74

Tabel 4.28. Eksekusi Berita acara Tim penyelesaian Kasus 75

Tabel 4.29. Peta/data sebaran sengketa/konflik $\quad 75$

Tabel 4.30. Kabupaten dan Kota di Provinsi NTB 77

Tabel 4.31. Tipologi Masalah Pertanahan 80

Tabel 4.32. Tipologi Kasus Pertanahan hasil RDP 81

Tabel 4.33. Frekwensi kasus Pertanahan dan penyelesaiannya 81

Tabel 4.34. Aspek yang diteliti dalam penelitian mengenai akar masalah 82

Tabel 4.35. Tim Khusus Penyelesaian Kasus Pertanahan 83 
Tabel 4.36. Eksekusi Berita acara Tim penyelesaian Kasus

Tabel 4.37. Peta/data sebaran sengketa/konflik

Tabel 5.1. Tipologi Masalah Pertanahan Lokasi Penelitian Tahun 2012

Tabel 5.2. Tim Khusus Penyelesaian Kasus Pertanahan

Tabel 5.3. Peta Sebaran Masalah Pertanahan

Tabel 5.4. Dasar Pengaduan

Tabel 5.5. Dasar Pelaksanaan Tugas Mediator Memimpin Mediasi

Tabel 5.6. Tahapan Mekanisme Mediasi yang seharusnya dilakukan

Tabel 5.7. Waktu Pelaksanaan Mediasi

Tabel 5.8. Fasilitasi/mediasi

Tabel 5.9. Wewenang yang seharusnya dimiliki, menurut responden

Tabel 5.10. Hak dan Kewajiban Mediator

Tabel 5.11. Lisensi diatur dalam perundangan-undangan

101

Tabel 5.12. Masalah yang dapat dimediasi

102

Tabel 5.13. Yang dapat menjadi mediator

103

Tabel 5.14. Pembuatan Berita Acara Perdamaian (BAP)

104

Tabel 5.15. Pendaftaran Berita Acara Perdamaian (BAP)

Tabel 5.16. Pelanggaran Berita Acara Perdamaian (BAK)

Tabel 5.17. Tindakan

Tabel 5.18. Usulan Titel Eksekutorial di BAK 


\section{Daftar Gambar}

\section{B. GAMBAR}

Gambar 4.1. Provinsi Maluku $\quad 36$

Gambar 4.2. Peta Administrasi Provinsi Lampung 47

Gambar 4.3. Peta Administrasi Provinsi Kalimantan Selatan 57

Gambar 4.4. Provinsi Jawa Barat $\quad 68$

Gambar 4.5. Peta Provinsi Nusa Tenggara Barat $\quad 76$

Gambar 4.6. Pelaksanaan Diskusi Di Kantor Pertanahan Kabupaten Lampung Tengah $\quad 85$

Gambar 4.7. Pelaksanaan Mediasi Di Nusa Tenggara Barat 86

Gambar 4.8. Konsultasi Hukum dari DPRD Kabupaten Tapin Di Kantor Wilayah BPN Provinsi Kalimantan Selatan $\quad 87$

Gambar 4.9. Seminar Laporan Akhir Penelitian 87

Gambar 5.1. Tipologi Masalah Pertanahan Lokasi Penelitian Tahun 2012 


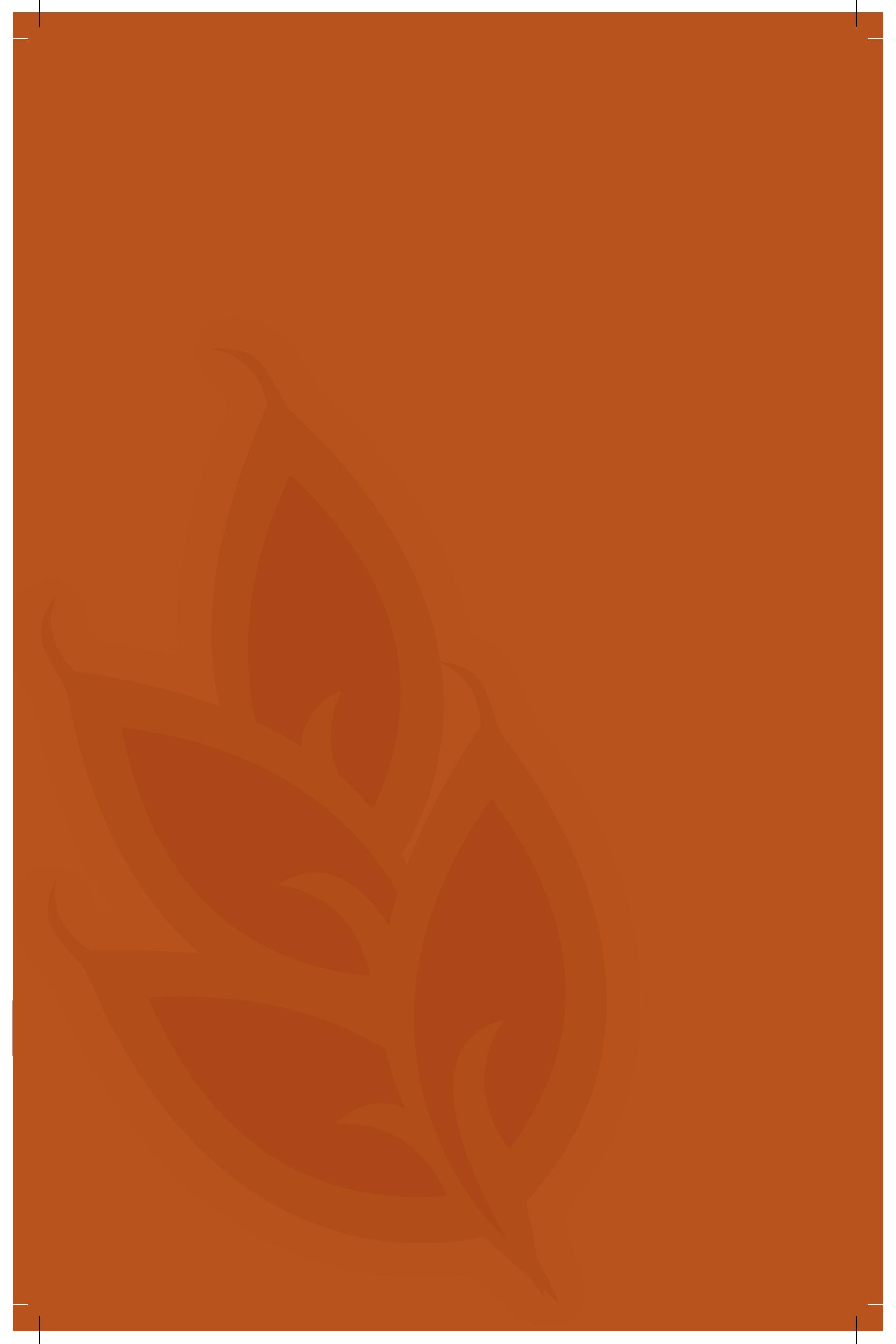


Bab I
Pendahuluan 


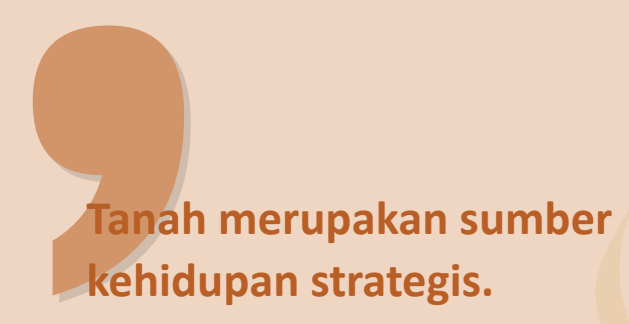

Tanah mempunyai

nilai ekonomis karena

luasnya tidak bertambah

sehingga menimbulkan

keinginan bagi manusia

untuk menguasai tanah

seluas-luasnya. Hal ini

menyebabkan terjadinya

ketimpangan penguasaan

dan pemilikan tanah serta

berpotensi menimbulkan

sengketa dan konflik

pertanahan, terlebih

apabila kurang jaminan

kepastian hukum terhadap

tanah yang dikuasai/

dimiliki.

\section{LATAR BELAKANG}

Beberapa pakar menilai ${ }^{1}$, konflik agraria akan terjadi apabila terdapat benturan intra dan antar subyek agraria ataupun tumpang tindih klaim akses terhadap obyek agraria. Gejala konflik dalam hubungan-hubungan agraria ini berakar dari, pertama, pada pertentangan klaim: a. Siapa yang berhak menguasai sumber-sumber agraria dan kekayaan alam yang menyertainya; b. Siapa yang berhak memanfaatkan sumbersumber agraria dan kekayaan alam itu; c. Siapa yang berhak mengambil keputusan atas penguasaan dan pemanfaatan sumber-sumber agraria dan kekayaan alam tersebut; Kedua. Konflik agraria juga bersumber dari kenyataan ketimpangan atau incompatibilities, yang meliputi: a. Ketimpangan dalam hal struktur pemilikan dan penguasaan tanah;

b. Ketimpangan dalam hal peruntukan tanah; c. Ketimpangan dalam hal persepsi dan konsepsi mengenai agraria.

Dinamika dan akar masalah konflik pertanahan merupakan persoalan struktural yang terindentifikasi dari, Pertama, struktur agraria yang timpang akibat warisan kolonial dan orde baru. Kedua, tanah hanya dinilai dari utilitas ekonominya, sementara itu terjadi reduksionisme nilai tanah dari sisi sosial, budaya, religius dan politik. Ketiga, tanah dijadikan sarana investasi dan spekulasi, terjadinya perubahan fungsi tanah yang asalnya sebagai alat produksi berubah menjadi alat investasi dan spekulasi. Keempat, terjadi konsentrasi kepemilikan

1. Endriatmo Soetarto dan Moh. Shohibudin, Menegaskan Kembali Keharusan Reforma Agraria sebagai Basis Pembangunan Pertanian dan Pedesaan (Agenda untuk Pemerintahan 2004-2009), Jurnal Pembaruan Desa dan Agraria, Volume 01/Tahun I/2004, Progam Studi Sosiologi Pedesaaan IPB-Pusat Kajian Agraria IPB-Lapera Indonesia 
tanah sebagai akibat pengkomodifikasian tanah. Kelima, adanya keharusan struktural berupa resiko yang harus ditanggung oleh Negara karena pemerintah telah menandatangani perjanjian internasional yang menghapus hambatan investasi seperti dengan World Bank, Asian Development Bank, International Monetary Fund dan World Trade Organization. Keenam, kebijakan pertanahan juga terperangkap pada model pembangunan yang berorientasi pertumbuhan ekonomi dengan mengedepankan investasi baik modal dalam negeri maupun model penanaman modal asing (Foreign Direct Investment) ${ }^{2}$.

Dampak dari konflik pertanahan ini, tidak saja kekerasan struktural dan kemiskinan strukural tetapi juga ketidakpastian status tanah, yang berarti juga terhalanginya kepastian hukum dan keadilan sosial bagi seluruh rakyat Indonesia. Akan tetapi sesungguhnya juga konflik pertanahan yang bersifat privat maupun struktural adalah wujud dari lemahnya adminitrasi pertanahan yang memerlukan reformasi birokrasi pertanahan, di mana adminitrasi pertanahan dan birokrasi pertanahan di Indonesia telah banyak diwarnai sebuah periode komersialisasi dan sektoralisasi pertanahan ketika pertanahan dijadikan modal pembangunan yang berorientasi pertumbuhan yang merupakan ciri khas dari pembangunanisme (developmentalism) dan neo liberalisme. Bahwasanya implikasi dari paradigma pembangunan nasional yang menjadikan sumber daya alam sebagai modal pembangunan dengan economic growth development (pembangunan yang diorientasikan untuk mengejar pertumbuhan ekonomi) semata (dimensi target) dengan mengabaikan dimensi proses adalah: Pertama. Use oriented (eksploitasi) bukan resource oriented; Kedua. High Capital, yaitu keperpihakan kepada pelaku usaha dengan dominasi pemodal besar;

Ketiga. Sektoral dalam manajemen pengelolaan sehingga menimbulkan conflict of interest; Keempat. Limitasi terhadap ruang akses informasi, transparansi, partisipasi publik dan akuntabilias publik; Kelima. Pengabaian hak dan aksi masyarakat adat serta kemajemukan hukum; Keenam. Political of Ignorance, yaitu politik pengabaian hak masyarakat hukum adat ${ }^{3}$.

Trend kasus pertanahan mengalami perubahan dari masa ke masa sesuai dengan fenomena permasalahan yang ditemukan. Kondisi ini dapat di lihat dari adanya data kasus sengketa dan konflik pertanahan Direktorat Konflik Pertanahan pada tahun 2011 yang menunjukkan tipologi masalah pertanahan ada 8 jenis yaitu yang pertama dan mayoritas di temukan pada seluruh provinsi di Indonesia adalah masalah penguasaan dan pemilikan Tanah yang mencapai 78, $28 \%$, yang kedua adalah masalah batas/ letak bidang tanah mencapai 9,09\%, yang ketiga adalah masalah prosedur penetapan hak \& pendaftaran tanah sebesar 7,58\%, keempat adalah masalah pelaksanaan

2. dimodifikasi dari Masoed (1997) oleh Achmad Ya’kub, dalam Konflik Agraria, Tinjauan Umum Kasus Agraria di Indonesia, (Jakarta: Federasi Serikat Petani Indonesia 2007), hal 20-22

3. I Nyoman Nurjaya, (2010) Prinsip-Prinsip Pengelolaan Sumber Daya Alam, Keterangan Ahli dalam Persidangan Uji Materi (Judicial Review) Undang-Undang Pengelolaan Wilayah Pesisir dan Pulau-Pulau Kecil di Mahkamah Konstitusi, Jakarta 
putusan pengadilan sebesar 3,28\%, kelima masalah tanah ulayat sebesar 0,51\%, keenam masalah tanah obyek landreform sebesar 0,51\%, ketujuh masalah ganti rugi tanah ex. Partikelir sebesar 0,42\% dan kedelapan masalah pengadaan tanah sebesar 0,34\%. belum habis dan belum diperpanjang

3. Konflik pemegang HGU dengan masyarakat sebagai akibat pelaksanaan dari pola kemitraan

4. Konflik mengenai tanah bekas hak barat (konversi) yang tumpang tindih dengan tanah masyarakat

\section{TABEL 1.1. TIPOLOGI MASALAH PERTANAHAN}

\begin{tabular}{|c|l|c|}
\hline NO. & \multicolumn{1}{|c|}{ TIPOLOGI } & PRESENTASE \\
\hline 1. & Masalah Penguasaan dan Pemilikan Tanah & $78.28 \%$ \\
\hline 2. & Masalah batas/letak bidang tanah & $9.09 \%$ \\
\hline 3. & Masalah prosedur Penetapan Hak \& Pendaftaran Tanah & $7.58 \%$ \\
\hline 4. & Masalah pelaksanaan putusan pengadilan & $3.28 \%$ \\
\hline 5. & Masalah tanah ulayat & $0.51 \%$ \\
\hline 6. & Masalah tanah obyek Landreform & $0.51 \%$ \\
\hline 7. & Masalah ganti rugi tanah ex. Partikelir & $0.42 \%$ \\
\hline 8. & Masalah pengadaan tanah & $0.34 \%$ \\
\hline
\end{tabular}

Sumber: Direktorat Konflik Pertanahan BPN RI, 2011

Selain tipologi di atas, dari hasil penelitian Puslitbang BPN RI pada tahun 2011 di lima provinsi yaitu Papua, Sulawesi Utara, Jambi, Bali dan Banten diperoleh tipologi sengketa dan konflik pertanahan, dimana hampir seluruhnya merupakan masalah penguasaan dan pemilikan tanah, juga ditemukan tipologi masalah batas/letak dan bidang tanah, dan masalah tanah ulayat ditemukan di Papua. Akar masalah terjadinya konflik tersebut meliputi berbagai hal antara lain:

1. Konflik atas tanah masyarakat yang diklaim masuk dalam kawasan hutan

2. Konflik di areal HGU, baik yang sudah habis masa berlakunya maupun yang
5. Konflik atas desa adat dengan masyarakat desa adat, desa adat tidak boleh memiliki hak Milik tetapi tanah laba pura yang berada di bawah desa adat dapat menjadi Hak Milik

6. Konflik di Papua, sebagai akibat adanya New York Agreement tahun 1966 yang dikuatkan oleh PBB dan diratifikasi menjadi UU No. 7 tahun 1966 tentang Persetujuan antara Pemerintah penjajahan Belanda dan pemerintah Kerajaan belanda dengan pemerintah Republik Indonesia tentang soal-soal keuangan, dengan adanya agreement ini maka status tanah peninggalan menjadi tanah yang langsung dikuasai oleh Negara RI. 
Dalam perkembangannya, tipologi kasus pertanahan yang ada pada Kedeputian Penanganan Sengketa, Konflik dan Perkara Pertanahan mengalami perubahan setelah Rapat Dengar Pendapat (RDP) yang dilakukan dengan Dewan Perwakilan Rakyat (DPR) pada Februari $2013^{4}$. Tipologi kasus pertanahan setelah RDP dengan DPR, yaitu:

1. Kasus pertanahan terkait masyarakat dengan swasta

2. Kasus pertanahan terkait BUMN

3. Kasus pertanahan terkait TNI-POLRI

4. Kasus pertanahan terkait Masyarakat adat

5. Kasus pertanahan terkait Kehutanan

6. Kasus pertanahan terkait ESDM/ Pertambangan

7. Kasus pertanahan terkait PU/BMN lainnya

Tipologi kasus pertanahan tersebut di atas memakai acuan yang diajukan dari pihak DPR saat diadakan RDP, tipologi tersebut telah disepakati dan merupakan upaya untuk melakukan sinkronisasi dengan satuan kerja yang ada di DPR maka jumlah tipologi permasalahan yang semula delapan dirubah menjadi tujuh. Upaya sinkronisasi ini merupakan bentuk pelibatan DPR secara nyata sebagai wakil rakyat dalam penanganan dan penyelesaian kasus pertanahan, sementara disepakati juga bahwa leading sector dalam kasus pertanahan diserahkan kepada BPN RI.

Kedeputian Penanganan Sengketa Konflik dan Perkara Pertanahan di BPN RI ternyata tidak bertugas menyelesaikan masalah tetapi menangani masalah, sehingga yang sebenarnya dilakukan BPN terhadap masalah pertanahan adalah fasilitasi bukan mediasi ${ }^{5}$, dimana dalam fasilitasi yang dilakukan oleh fasilitator hanyalah memberikan memberikan fasilitas kepada para pihak untuk saling berdiskusi menyelesaikan masalahnya sendiri tanpa turut campur menjadi pihak penengah guna mempercepat penyelesaian masalah sebagaimana yang terjadi pada proses mediasi. Keberadaan mediator bersertipikat di BPN selain masih minim juga masih tersebar secara sporadik karena proses rotasi-mutasi kelembagaan.

Permasalahan pertanahan yang ada saat ini ternyata sebagian besar merupakan kesalahan yang diperbuat oleh oknum pegawai pada masa lalu, hal ini dapat dilihat dari sebagian besar permasalahan yang ditangani oleh Seksi Sengketa dan Konflik Pertanahan pada Kantor-kantor Pertanahan di daerah adalah permasalahan produk BPN sendiri. Kerumitan tersebut ditambah dengan keharusan melibatkan seksi atau bidang lain dalam penanganan permasalahan tersebut sehingga seringkali terjadi perbedaan persepsi yang memperlarut penanganan masalah tersebut $^{6}$.

Untuk kasus pertanahan yang berkaitan dengan instansi/kementrian lain, maka kementrian/instansi tersebut yang melakukan penanganan, sehingga mediasi dilakukan di antara mereka,

4. Agus Sugiyanto, Kasi Konflik Masyarakat dengan Badan Hukum Privat, disampaikan pada rapat Penyusunan Riset Desain Penelitian, 08 April 2013

5. Agus Sugiyanto, Kasi Konflik Masayarakat dengan Badan Hukum Privat, disampaikan pada rapat pembahasan ToR penelitian, 27 Maret 2013

6. Kepala Seksi Sengketa dan Konflik Pertanahan Kota Tangerang, disampaikan pada rapat pembahasan ToR penelitian, 27 Maret 2013 
kecuali memang diminta oleh instansi tersebut kepada BPN untuk ikut terlibat dalam penanganannya. Contohnya: kehutanan, masalah klasik, tidak pernah mengikutsertakan BPN. Terkait dengan tim sebelas masalah mediasi, beberapa kasus di Jawa Barat yang dicoba selesaikan dengan mediasi, terbentur dengan instansi-instansi lain, sudah bukan menjadi domein BPN lagi (menyangkut aset negara), merupakan kendala mendasar sebelum kita melakukan mediasi.

Penyelesaian konflik dan sengketa pertanahan selama ini diupayakan untuk diselesaikan melalui mediasi dan jika mediasi tidak dapat menyelesaikannya maka ditempuh jalur litigasi yaitu penyelesaian melalui badan peradilan. Penyelesaian melalui mediasi dapat mengurangi resiko hilangnya waktu, biaya, dan sebagainya apabila ditempuh melalui jalur peradilan, hanya saja peran mediator belum efektif dalam percepatan penyelesaian sengketa dan konflik pertanahan. Hasil mediasi selama ini sering tidak di taati oleh para pihak yang telah melakukan mediasi, seperti di Jakarta Timur, ada hasil mediasi yang tidak didaftarkan dan selesai dengan baik, ada hasil mediasi yang sudah didaftarkan ke pengadilan tetapi malah menjadi masalah yang lebih besar lagi, didaftarkan ke pengadilan tidak menjadi jaminan hasil mediasi akan dilaksanakan oleh para pihak ${ }^{7}$

Mediator seharusnya diberikan peran dan wewenang yang lebih besar sehingga penyelesaian sengketa dan konflik dapat dilaksanakan secara optimal artinya prosesnya mudah, waktunya terbatas tidak berlarut-larut dan memberikan jaminan kepastian hukum kepada para pihak yang bersengketa.

Penelitian ini diharapkan dapat merumuskan bagaimana seharusnya peran seorang mediator dan materi muatan dalam Peraturan Kepala Badan No. 3 tahun 2011 dapat mengakomodir hal itu, serta bila terjadi kesepakatan yang kemudian ditanda tangani, sudah didaftarkan ke pengadilan, ternyata salah satu pihak cidera janji, bagaimana kewenangan BPN dalam menangani sampai tahap penyelesaiannya yaitu eksekusi, karena perlunya kepastian hukum dalam pelaksanaan hasil kesepakatan.

\section{PERMASALAHAN}

Dari uraian di atas, maka mediator harus diberikan peran yang lebih optimal dalam rangka penyelesaian sengketa dan konflik pertanahan, oleh karena itu permasalahan penelitian meliputi :

1. Bagaimana pengaturan penyelesaian masalah pertanahan melalui mediasi menurut peraturan per-UU an yang berlaku (produk hukum pertanahan peraturan teknisnya)?

2. Bagaimana peningkatan peran mediator dalam percepatan penyelesaian sengketa dan konflik pertanahan?

3. Bagaimana memberikan kepastian hukum terhadap hal-hal yang disepakati para pihak dalam proses mediasi?

7. Francisco, Kasi Sengketa, Konflik dan Perkara Kantor Pertanahan Jakarta Timur, disampaikan pada rapat penyusunan Riset Desain, 8 April 2013 


\section{TUJUAN}

1. Mendiskripsikan pengaturan penyelesaian masalah pertanahan melalui mediasi menurut peraturan per-UU an yang berlaku (produk hukum pertanahan - peraturan teknisnya)

2. Mendiskripsikan peningkatan peran mediator dalam percepatan penyelesaian sengketa dan konflik pertanahan

3. Mendiskripsikan aspek kepastian hukum terhadap hal-hal yang disepakati para pihak dalam proses mediasi.

\section{HASIL PENELITIAN (OUTPUT)}

Output penelitian berupa laporan mengenai profil proses mediasi dan hasilnya serta usulan penguatan peran mengenai tugas, fungsi dan wewenang mediator serta aspek kepastian hukum hasil mediasi dan implementasinya.

\section{KEGUNAAN PENELITIAN}

Hasil penelitian ini diharapkan akan menjadi:

1. Secara teoritis menjadi bahan pengembangan pengetahuan bagi penguatan peran mediator;

2. Secara praksis sebagai landasan dalam pengambilan kebijakan di BPN RI mengenai perlunya penguatan, peran, tugas, fungsi dan wewenang mediator serta aspek kepastian hukum atas hasil mediasi sehingga hasil mediasi menjadi optimal. 


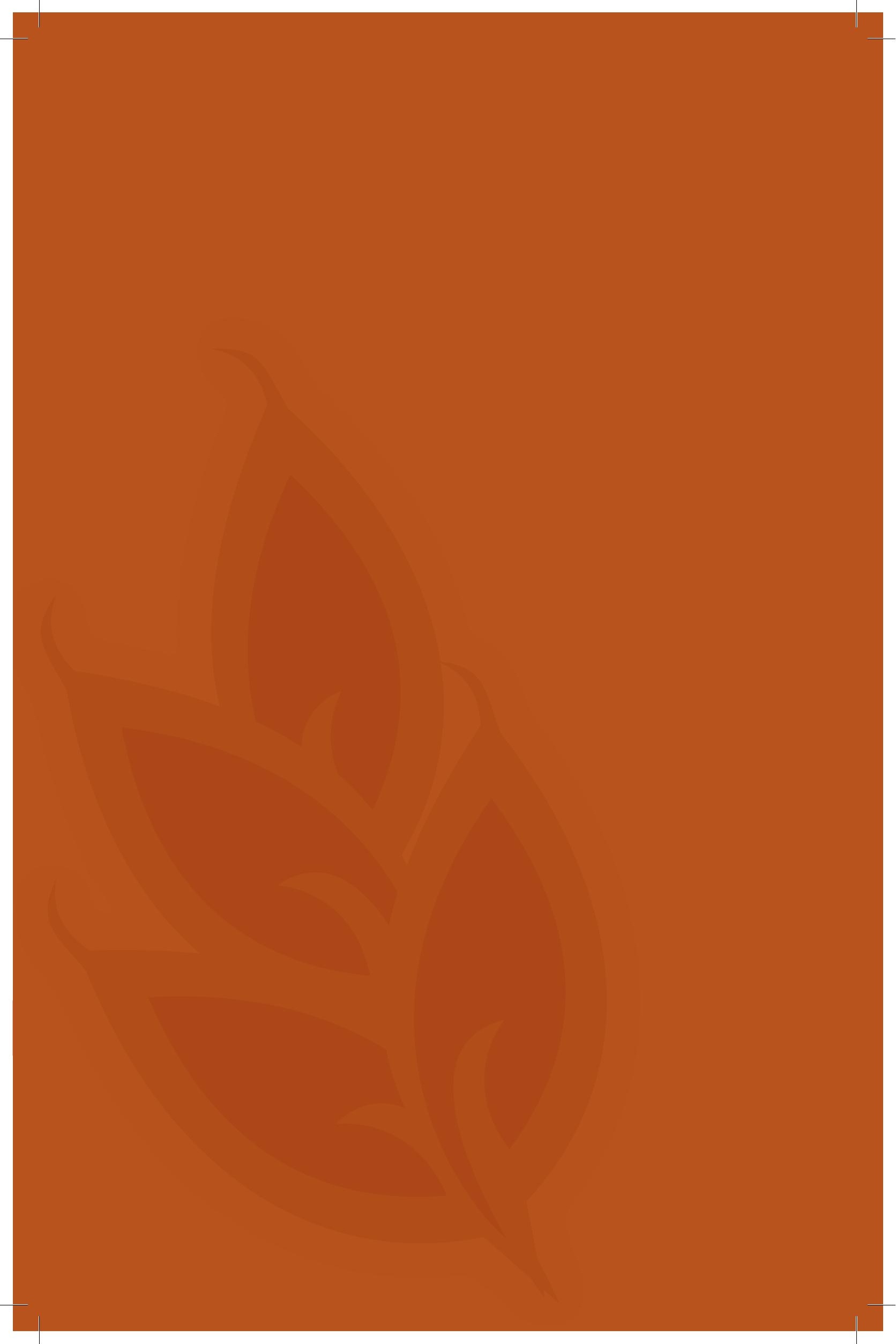





\section{KERANGKA TEORI}

Sebagian besar kasus-kasus tersebut berasal dari lingkungan peradilan Umum. Di samping itu ada juga perkara-perkara tanah yang masuk dalam lingkungan peradilan Agama (misalnya sengketa tanah warisan dan tanah wakaf) dan dalam lingkungan peradilan Tata Usaha Negara (seperti tuntutan pembatalan sertifikat tanah).

\section{sengketa pertanahan}

dalam masyarakat akhir-

akhir ini cenderung

meningkat. Akumulasi

perkara pertanahan yang

masuk ke Mahkamah

Agung diperkirakan

berkisar antara 65\% hingga

$70 \%$ setiap tahun, belum

terhitung yang selesai

ketika diputus pada tingkat

pertama maupun pada

tingkat banding.
Munculnya konflik dan sengketa pertanahan dimaksud antara lain karena tanah terutama di daerah perkotaan sudah kembali menjadi "komoditas" primadona. Dalam kurun waktu sepuluh tahun saja harga tanah di suatu tempat telah naik berlipat ganda sekitar 200\% hingga 500\%. Kegiatan pembangunan yang berlangsung di sekitar tanah-tanah yang bersengketa turut memicu peningkatan nilai tanah sehingga harganya menjadi melangit dan menjadikan tanah sebagai sumber sengketa spekulasi tanah (land speculation) juga merupakan pemicu yang tidak kalah pentingnya bagi terjadinya berbagai sengketa pertanahan di samping alasan pokok semakin tidak seimbangnya pertumbuhan penduduk dengan luas tanah yang tersedia.

Selain di perkotaan, konflik yang berkaitan dengan sumber daya alam atas hutan, perkebunan dan pertambangan menunjukkan peningkatan yang signifikan dari tahun ke tahun, dan berpotensi meningkat menjadi persoalan nasional.

Dalam suatu sengketa tanah tidak selamanya berpangkal dari tuntutan warga masyarakat yang tanahnya diokupasi oleh orang lain yang tidak berhak, tetapi tidak jarang terjadi tuntutan mereka yang merasa berhak dan orang-orang yang berspekulasi menuntut tanah orang lain yang ingin dikuasainya karena mereka mengetahui "si pemilik" tidak 
punya bukti yang kuat terhadap tanahnya. Selain itu juga tidak jarang terjadi sengketa tanah yang justru berpangkal pada tidak adanya jaminan kepastian hukum dari alat bukti yang dipunyai oleh pemilik tanah termasuk sertifikat tanah yang dikeluarkan oleh Badan Pertanahan Nasional (BPN).

Konflik dan sengketa tanah juga banyak terjadi berkenaan dengan berbagai "transaksi tanah" yang dimunculkan dalam berbagai model transaksi bisnis yang dapat memungkinkan beralihnya kepemilikan atau penguasaan tanah dari satu tangan ke tangan yang lain tanpa disadari atau sepengetahuan dari mereka yang sebenarnya berhak atas tanah yang bersangkutan. Pemilikan dan penguasaan tanah masih belum mendapatkan jaminan yang kuat dari perangkat hukum yang berlaku. Selain itu ada pula sengketa pertanahan di mana pemilik tanah atau mereka yang menguasai tanah berhadapan dengan instansi pemerintah atau perusahaan-perusahaan yang berada di bawah naungan pemerintah.

Menurut Takdir Rahmadi, bangsa Indonesia, paling tidak secara normatif dan historis dipandang sebagai bangsa yang amat menjunjung nilai-nilai pendekatan mufakat/ konsensus dalam penyelesaian persoalanpersoalan dalam masyarakat. Dalam beberapa masyarakat adat dapat dijumpai istilah-istilah yang menggambarkan nilai penting pendekatan mufakat/konsensus dalam penyelesaian persoalan. Bahkan para pendiri Negara Indonesia memiliki keyakinan bahwa pendekatan musyawarah mufakat merupakan nilai luhur bangsa yang kemudian diaktualisasikan sebagai cara pengambilan keputusan sebagaimana dituangkan dalam sila ke-4 Pancasila ${ }^{1}$.
Sebagai negara berasaskan Pancasila yang menjunjung tinggi asas musyawarah untuk mufakat, maka pertama-tama jika terjadi sengketa diupayakan penyelesaiannya secara musyawarah. Musyawarah untuk mufakat sudah dikenal dalam hukum adat Indonesia untuk menyelesaikan suatu perselisihan, sebagai contoh Pemuka Adat setempat atau Kepala Desa sering menyelesaikan sengketa yang timbul di masyarakat baik perselisihan di bidang perkawinan, jual beli, hutang piutang, warisan dan sebagainya.

Sengketa dan konflik pertanahan mempunyai dimensi luas menyangkut beberapa aspek, seperti aspek perdata, pidana dan administrasi sehingga sengketa pertanahan dimungkinkan untuk digugat di dua badan peradilan yaitu peradilan umum dan peradilan TUN.

Jika terjadi sengketa karena cacat administrasi, maka koreksi dilakukan oleh BPN, pada umumnya dilakukan dalam bentuk pembatalan Surat Keputusan Pemberian Hak Atas Tanah atau sertipikat hak atas tanah, baik karena dijumpai adanya cacat hukum administrasi dalam penerbitan keputusan pemberian dan/atau sertipikat hak atas tanah atau karena melaksanakan putusan pengadilan.

Jika sengketa pertanahan di proses melalui peradilan maka penyelesaiannya akan membutuhkan waktu bertahun-bertahun bahkan mungkin puluhan tahun, karena sengketa yang sudah diputus di PTUN, dapat digugat kembali melalui Peradilan Umum. Hal ini dimungkinkan dalam pasal 55 UU No. 5 tahun 1986 dimana dinyatakan bahwa suatu keputusan TUN yang ada kaitannya

1. Takdir Rahmadi, Mediasi, Penyelesaian Sengketa melalui Pendekatan Mufakat, Rajawali Pers, 2010 
dengan suatu perbuatan Onrechtmatige Overheidsdaad (OOD) yang menjadi wewenang Peradilan Umum maka dengan mengingat adanya tenggang waktu pengajuan gugatan dalam sengketa TUN, gugatan harus diajukan terlebih dulu ke PTUN dan diperiksa/ diputus sampai tuntas. Setelah itu barulah dapat diajukan gugatan OODnya ke Peradilan Umum yang berwenang. Dengan demikian tidak diperkenankan kedua macam gugatan itu berjalan bersamaan untuk menghindari putusan yang saling bertentangan antara kedua Pengadilan tersebut yang mempunyai kompetensi absolute masing. Kompetensi peradilan ini juga diperkuat oleh SE MA tertanggal 14 Oktober 1993 Nomor 223/ Td.TUN/X/1993.

Dimungkinkannya suatu perkara untuk diperiksa di Peradilan TUN dan Peradilan Umum berakibat diabaikannya prinsipprinsip yang dianut dalam pelaksanaan Badan Peradilan di Indonesia yaitu sederhana, cepat dan murah sebab dengan pemeriksaan suatu perkara (sengketa pertanahan) oleh 2 badan peradilan selain memerlukan waktu yang relative lama, biaya besar juga akan sangat mempengaruhi kinerja pelayanan pertanahan dan kepastian hukum.

Dalam hal kompetensi peradilan Philipus $M$. Hadjon berpendapat dalam KUHP terdapat kemungkinan untuk menggabungkan perkara pidana dan perkara perdata, apakah ada kemungkinan menggabungkan perkara perdata dengan sengketa TUN atau perkara pidana dengan sengketa TUN dalam hokum acara Peradilan Tata Usaha Negara hendaknya menjadi suatu kajian dalam pengembangan hukum administrasi di Indonesia. Mungkin sudah saatnya mulai dipikirkan kemungkinan integrasi badan-badan pengadilan dalam usaha lebih meningkatkan perlindungan hokum bagi rakyat Indonesia².
Dalam banyak perkara yang masuk ke Pengadilan yang sering dirasakan tidak memuaskan adalah karena banyak Pengadilan yang memutus dengan menyatakan gugatan tidak dapat diterima atau "niet van ontvankelijke verklaard" yang lazim dikenal dengan sebutan "NO" oleh karena penggugat mengajukan gugatan tidak sempurna berkenaan dengan letak dan ukuran tanah dan batas-batas tanah yang digugat masih kabur atau tidak jelas. Gugatan juga dinyatakan tidak dapat diterima adalah apabila penggugat hanya menggugat mereka yang menguasai tanah saja sedangkan jelas dan diketahui bahwa tergugat mendapatkan tanah dari orang tertentu sedangkan orang tersebut tidak digugat dalam perkara yang bersangkutan.

Terjadinya konflik dan sengketa pertanahan tidak terlepas dari proses dalam penyelenggaraan pendaftaran tanah dan dikeluarkannya sertipikat sebagai alat bukti hak. Pasal 32 ayat 1 PP No. 24 tahun 1997 disebutkan sertipikat berlaku sebagai alat bukti yang kuat. Artinya sertipikat merupakan alat bukti sempurna. Sepanjang tidak ada bukti sebaliknya, maka data fisik dan data yuridis yang tercantum dalam sertipikat harus diterima sebagai data yang benar.

\subsection{Alternative Dispute Resolution}

Penyelesaian konflik dan sengketa tanah (atau sengketa perdata pada umumnya) dimungkinkan untuk menggunakan dua macam cara penyelesaian yaitu melalui pengadilan dan diluar pengadilan. Penyelesaian yang dilakukan di luar Pengadilan atau disebut Alternative Dispute Resolution. Alternative Dispute Resolution (ADR) adalah merupakan istilah asing yang

2. Hadjon, Philipus M, Pengantar Hukum Administrasi Indonesia, Yogyakarta, Gajah Mada University Press, 1994. 
masih perlu dicarikan padanannya dalam bahasa Indonesia. Beberapa istilah dalam bahasa Indonesia telah diperkenalkan dalam berbagai forum oleh berbagai pihak. Beberapa diantaranya yang telah dapat diindentifikasi adalah: penyelesaian sengketa alternatif ${ }^{3}$, alternatif penyelesaian sengketa $(\mathrm{APS})^{4}$, mekanisme alternatif penyelesaian sengketa (MAPS) ${ }^{5}$ dan pilihan penyelesaian sengketa (PPS) ${ }^{6}$.

Ada dua pemahaman yang berbeda terhadap arti ADR tersebut. Pertama, ADR diartikan sebagai alternative to litigation dan yang kedua ADR diartikan dengan alternative to adjudication. Pemilihan terhadap salah satu dari kedua pengertian tersebut menimbulkan implikasi yang berbeda. Apabila pengertian pertama yang menjadi acuan (alternative to litigation), maka seluruh mekanisme penyelesaian sengketa di luar pengadilan termasuk arbitrase merupakan bagian dari ADR. Tetapi apabila ADR diartikan sebagai alternative to adjudication, maka hanya mekanisme penyelesaian sengketa yang bersifat konsensus atau kooperatif saja yang merupakan ADR. Sedangkan arbitrase yang bersifat ajudikasi tidak termasuk di dalamnya, karena sama halnya dengan pengadilan cenderung menghasilkan putusan dengan solusi menang-kalah (win-lose). Sebelum mencari padanan istilah yang tepat dalam bahasa Indonesia terlebih dahulu diperlukan penyamaan persepsi tentang konsep dan pemahaman terhadap ADR tersebut.

Jika dikaitkan dengan Undang-Undang Nomor 30 Tahun 1999 tentang Arbitrase dan Alternatif Penyelesaian Sengketa, maka Indonesia juga merupakan salah satu penganut dari pandangan yang kedua, karena undang-undang tersebut memisahkan secara tegas istilah arbitrase dengan alternatif penyelesaian sengketa. Alternatif
Penyelesaian Sengketa adalah lembaga penyelesaian sengketa atau beda pendapat melalui prosedur yang disepakati oleh para pihak yakni penyelesaian diluar pengadilan dengan cara konsultasi , negosiasi, mediasi, konsiliasi, atau penilaian ahli (Vide Pasal 1 butir 10 UU No. 30 Tahun 1999).

ADR memiliki potensi untuk menyelesaikan konflik-konflik yang sangat rumit yang disebabkan oleh substansi kasus yang berat dengan persoalan-persaoalan ilmiah. ADR mempunyai daya tarik khusus di Indonesia karena kerahasiaanya dengan sistem budayasosial berdasarkan musyawarah mufakat. Dengan musyawarah dan mufakat yang dilakukan untuk menyelesaikan sengketa tersebut mampu mendatangkan bernagai keuntungan baik itu misalnya keuntungan dari segi waktu, biaya dan tenaga yang dibutuhkan ubtuk menyelesaikan suatu sengketa. Adapun beberapa hal-hal yang merupakan keuntungan yang sering muncul dalam ADR antara lain ${ }^{7}$ :

a) Sifat kesukarelaan dalam proses. Para pihak percaya bahwa ADR memberikan jalan keluar yang potensial untuk

3. Erman Rajagukguk, Arbitrase Dalam Putusan Pengadilan (Jakarta: Chandra Pratama, 2000); Perhatikan juga Ali Budiharjo dkk, Reformasi Hukum di Indonesia (Jakarta: Cyber Consult, 1999); Baca juga Suyud Margono, ADR \& Arbitrase. Proses Pelembagaan dan Aspek-Aspek Hukum (Jakarta: Ghalia Indonesia, 2000)

4. UU No. 30 Tahun 1999 tentang Arbitrase dan Alternatif Penyelesaian Sengketa; Baca juga Joni Emirzon, Alternatif Penyelesaian Sengketa di Luar Pengeadilan (Negoisasi, Mediasi, Konsultasi dan Arbitrase) (Jakarta: PT. Gramedia Pustaka Utama; 2001)

5. Takdir Rahmadi, Mekanisme alternatif Penyelesaian Sengketa Dalam Konteks Masyarakat Indonesia Masa Kini, makalah disajikan dalam Seminar Sehari Alternatif Penyelesaian Sengketa Dalam Kasus-Kasus Tanah, Perburuhan dan Lingkungan, Diselenggarakan Oleh Studi dan Advokasi Masyarakat bekerjasama dengan Dewan Pimpinan Pusat IKADIN, di Jakarta, 11 Agustus 1994

6. UU Nomor 23 Tahun 1997 tentang Pengelolaaan Lingkungan Hidup.

7. Suyud Margono, "Alternatif Dispute Resolution dan Arbitrase," Cet XI; Bogor: Galia Indonesia, 1993. 
menyelesaikan masalah dengan lebih baik dibandingka dengan prosedur litigasi dan prosedur lainya yang melibatkan para pembuat keputusan dari pihak ketiga. Secara umum, tidak seorang pun dipaksa unutk menggunakan prosedur ADR.

b) Prosedur yang cepat. Karena prosedur ADR bersifat Informal, pihak-pihak yang terlibat mampu untuk menegosiasikan syarat-syarat penggunannya. $\mathrm{Hal}$ ini mencegah terjadinya penundaan dan mempercepat proses penyelesaian sengketa.

c) Keputusan non yudisial. Wewenang untuk membuat keputusan tetap berada pada pihak-pihak yang terlibat atau tidak didelegasikan kepada pembuat keputusan dari pihak ketiga. Hal ini berarti bahwa pihak-pihak terlibat mempunyai lebih banyak kontrol terhadap hasil-hasil sengketa dan mampu meramalkan.

d) Kontrol tentang kebutuhan organisasi. Prosedur ADR menempatkan keputusan ditangan orang yang mempunyai posisi tertentu (penting), baik unutk menafsirkan tujuan-tujuan jangka panjang dan jangka pendek dari organisasi yang terlibat maupun menafsirkan dampak-dampak positif dan negative dari setiap pilihan penyelesaian masalah tertentu. Pihak ketiga dalam membuat keputusan yang mengikat suatu isu sering kali meminta bantuan seorang hakim, juri, atau arbiter.

e) Prosedur rahasia. Prosedur ADR memberikan jaminan kerahasiaan bagi para pihak dengan porsi yang sama. Pihakpihak dapat menjajaki pilihan-pilihan sengketa yang potensial dan hak-hak mereka dalam mempresentasikan data untuk menyerang balik tetap dilindungi.

f) Fleksibilitas dalam merancang syaratsyarat penyelesaian masalah. Prosedur
ADR memberikan fleksibilitas yang lebih besar bagi parameter isu yang sedang didiskusikan dan cakupan dari penyelesaian masalah. Disamping itu, memungkinkan pengembangan cara penyelesaian yang lebih komperhensip untuk membahas penyebab persengketaan. Prosedur ini dapat menghindari kendala prosedur yudisial yang sangat terbatas pada pembuatan keputusan pengadilan didasarkan pada titik sempit hukum, seperti apakah prosedur yang resmi sudah diikuti atau belum.

g) Hemat Waktu. Selama ini proses penyelesaian masalah sering mengalami hambatan yang cukup berarti dalam menunggu kepastian tanggal persidangan. Prosedur ADR menawarkan kesempatan yang lebih cepat untuk menyelesaikan sengketa tanpa harus menghabiskan waktu bertahun-tahun untuk melakukan litigasi. Dalam banyak hal waktu adalah uang dan penundaan penyelesaian masalah memerlukan biaya yang sangat mahal. Penyelesaian sengketa yang dikembangkan melalui penggunaan prosedur ADR merupakan alternatif penyelesaian masalah yang tepat.

h) Hemat biaya. Besarnya biaya biasa ditentukan oleh lamanya waktu yang dipergunakan. Pihak ketiga yang netral rata-rata memasang tarif yang lebih rendah untuk mengganti waktu mereka dibandingkan apabila membayar para pengacara hukum.

i) Pemeliharaan Hubungan ADR menghasilhan kesepakatan-kesepakatan yang dinegosiasikan dengan memperhatikan kebutuhan-kebutuhan pihak yang terlibat. Dengan kata lain, ADR mampu mempertahankan hubunganhubungan kerja yang sedang berjalan 
maupun untuk masa depan.

j) Tingginya kemungkinan untuk melaksanakan kesepakatan. Dalam $A D R$, para pihak yang telah mencapai kesepakatan cendrung untuk memenuhi syarat-syarat atau isi kesepakatan yang telah diambil oleh keputusan (pihak ketiga). Faktor ini membantu para pihak yang terlibat untuk meghindari litigasi yang tidak efektif.

k) Kontrol dan lebih mudah memperkirakan hasil. Pihak-pihak yang menegosiasikan sendiri sengketanya mempunyai lebih banyak control terhadap hasilhasil penyelesaian sengketa. Cara penyelesaian melaui negosiasi atau mediasi lebih meudah memperkirakan keuntungan dari kerugian dibandingkan jika kasus tersebut diselesaikan melalui arbitrase atau didepan hakim.

I) Keputusan bertahan sepanjang waktu. Keputusan penyelesaian sengketa dengan prosedur $A D R$ cendrung bertahan sepanjang waktu. Jika di kemudian hari persengketaan itu menimbilkan masalah, pihak-pihak terlibat lebih memanfaatkan bentuk pemecahan masalah yang kooperatif dibandingkan penerapan pendekatan adversial atau pertentangan.

\subsection{Dasar Hukum Mediasi}

1. Undang-undang HAM, Pasal 1 Undangundang HAM Nomor 39 Tahun 1999 tanah, bahwa Komisi Hak Asasi Manusia yang selanjutnya disebut Komnas HAM adalah lembaga yang mandiri yang kedudukannya setingkat dengan lembaga negara lainnya yang berfungsi melaksanakan pengkajian, penelitian, penyuluhan, pemantauan, dan mediasi hak asasi manusia.

Dalam UU HAM dinyatakan bahwa hasil mediasi seharusnya ditindaklanjuti dengan dicatatkan di pengadilan, tetapi selama ini Komnas HAM jarang melakukan hal ini, artinya kepastian hukum saja tidak cukup tetapi bagaimana implementasinya.

2. Pasal 6 Undang - undang Nomor 30 Tahun 1999 Tentang Arbitrase dan Alternatif Penyelesaian Sengketa, bahwa "Sengketa atau beda pendapat perdata dapat diselesaikan oleh para pihak melalui Alternatip Penyelesaian Sengketa yang didasarkan pada itikad baik dengan mengesampingkan penyelesaian secara litigasi di Pengadilan Negeri".

3. Keputusan MK terhadap UU Perkebunan No. 18 tahun 2004; mengenai ketentuan dalam konflik agraria merupakan persoalan perdata yang mengedepankan mediasi.

4. Pasal 130 HIR dan Pasal 154 RBG, Hakim wajib terlebih dahulu mendamaikan para pihak yang berperkara sebelum perkaranya diperiksa.

5. Peraturan Presiden Nomor 10 Tahun 2006 jo Peraturan Presiden No. 63 tahun 2013 tentang Badan Pertanahan Nasional

6. Peraturan Mahkamah Agung No. 1 tahun 2008 tentang Prosedur Mediasi di Pengadilan.

7. Peraturan Kepala Badan Pertanahan Nasional RI Nomor 3 Tahun 2011 Tentang Pengelolaan Pengkajian dan Penanganan Kasus Pertanahan.

\subsection{Ciri- ciri Mediasi ${ }^{8}$}

1. Proses penyelesaian sengketa melalui musyawarah/perundingan berpartisipasi secara langsung dan informal dalam menyelesaikan sengketa para pihak. 
2. Adanya pihak ketiga yang bersifat netral dan diterima oleh para pihak yang bersengketa.

3. Mediator membantu para pihak untuk mencapai penyelesaian atas sengketanya.

4. Mediator tidak mempunyai kewenangan memutus selama proses perundingan berlangsung.

5. Mempunyai tujuan untuk mencapai keputusan yang dapat diterima oleh masing - masing pihak yang bersengketa.

\subsection{Jenis Mediasi}

Ada dua jenis mediasi dalam PERMA No. 1 tahun 2008 yaitu :

a. Mediasi di Pengadilan, ada dua tahap yaitu pertama mediasi awal litigasi yakni mediasi yang dilaksanakan sebelum pokok sengketa diperiksa. Kemudian mediasi yang dilakukan dalam pokok pemeriksaan yang terbagi menjadi dua, yaitu selama dalam pemeriksaan tingkat pertama dan selama dalam tingkat banding dan kasasi.

b. Mediasi di luar Pengadilan yaitu mediasi yang dilakukan di luar Pengadilan kemudian perdamaian terjadi dimohonkan ke Pengadilan untuk dikuatkan dalam akta perdamaian.

Perbedaan utama antara mediasi di Pengadilan dan di luar Pengadilan adalah terletak pada pelaksanaan mediasi hokum jika dicapai kesepakatan dalam menyelesaikan sengketa.

Dalam mediasi di Pengadilan, penyelesaian sengketa itu diratifikasi dan disetujui oleh Hakim. Penyelesaian terhadap sengketa tersebut berupa suatu penetapan dari Hakim dan penetapan tersebut harus dilaksanakan oleh para pihak yang berperkara seolaholah telah diputuskan oleh Hakim, termasuk kekuatan penegakannya oleh Negara. Dalam mediasi diluar Pengadilan, hasilnya dalam bentuk kontrak (perjanjian).

Lawrence Boulle menyebutkan ada empat model mediasi yaitu settlement mediation, facilitative mediation, transformative mediation, dan evaluative mediation ${ }^{9}$.

Settlement mediation yang juga dikenal sebagai mediasi kompromi, merupakan mediasi yang tujuan utamanya adalah untuk mendorong terjadinya kompromi dari tuntutan kedua pihak yang bertikai.

Facilitative mediation disebut juga mediasi berbasis kepentingan (interest-based) dan problem solving. Dalam model ini, mediator harus ahli dalam proses dan harus menguasai teknik mediasi, meskipun penguasaan terhadap materi terhadap hal yang dipersengketakan tidak terlalu penting. Dalam hal ini sang mediator harus dapat memimpin proses mediasi dan mengupayakan dialog yang konstruktif diantara para pihak yang bersengketa, meningkatkan upaya negosiasi dan tercapainya kesepakatan.

Transformative mediation yang juga dikenal sebagai mediasi terapi dan rekonsiliasi merupakan mediasi yang menekankan untuk mencari penyebab yang mendasari munculnya permasalahan diantara para pihak. Dalam model ini mediator harus dapat menggunakan terapi dan teknik professional sebelum dan selama proses mediasi serta mengangkat isu relasi/hubungan melalui pemberdayaan dan pengakuan.

Evaluative mediation dikenal sebagai

9. Laurence Boulle, Mediation: Principle, process, practice (Sydney: Butterworths, 1996) 
mediasi normative merupakan model mediasi yang bertujuan untuk mencari kesepakatan berdasarkan pada hak-hak legal dari para pihak yang bersengketa. Dalam hal ini sang mediator harus seorang yang ahli dan menguasai bidang-bidang yang dipersengketakan meskipun tidak ahli dalam teknik mediasi.

\subsection{Tipe Mediator}

1. Mediator jaringan sosial (Social Network Mediator)

a. Dipilih karena dikenal para pihak.

b. Berasal dari lingkungan para pihak.

c. Tokoh yang dipercaya dapat membantu menyelesaikan sengketa.

2. Mediator Authoritative
a. Berasal dari kalangan yang berpengaruh atau mempunyai kedudukan yang kuat.
b. Karena mandat peraturan perundangan.
c. Memiliki kapasitas untuk mengarahkan hasil perundingan.
* Terkait masalah mediator bersertipikat di BPN, mediator tidak selalu harus satu orang bisa saja sebuah tim.

3. Mediator Mandiri (Independent Mediators) :

a. Dipilih karena potensinya.

b. Tidak mempunyai hubungan dengan para pihak.

\section{TAHAPAN PENANGANAN MASALAH} PERTANAHAN

Mekanisme penanganan masalah pertanahan pada umumnya ditempuh dengan cara :K1 - K5 yaitu:

1. K1: diselesaikan dengan surat pemberitahuan.

2. K2 : diselesaikan dengan surat pembatalan/pemberian hak.

3. K3 : diselesaikan dengan mediasi.
4. K4 : ditempuh jalur pengadilan.

5. K5: bukan wewenang BPN (tetapi instansi lain).

Gelar Kasus Pertanahan yang selanjutnya disingkat Gelar Kasus adalah mekanisme kelembagaan Badan Pertanahan Nasional Republik Indonesia dalam rangka penanganan dan/atau penyelesaian Kasus Pertanahan. Gelar penanganan dan/atau penyelesaian kasus pertanahan yang meliputi:

1. Gelar Kasus Internal adalah gelar yang pesertanya dari Kantor Badan Pertanahan Nasional Republik Indonesia, Kantor Wilayah Badan Pertanahan Nasional dan atau Kantor Pertanahan.

2. Gelar Kasus Eksternal adalah gelar yang pesertanya dari Kantor Badan Pertanahan Nasional Republik Indonesia, Kantor Wilayah Badan Pertanahan Nasional dan/atau Kantor Pertanahan yang diikuti peserta dari unsur/instansi lainnya.

3. Gelar Mediasi adalah gelar yang menghadirkan para pihak yang berselisih untuk memfasilitasi penyelesaian kasus pertanahan melalui musyawarah.

4. Gelar Istimewa adalah gelar yang dilaksanakan oleh Tim Penyelesaian Kasus Pertanahan yang dibentuk oleh Kepala Badan Pertanahan Nasional Republik Indonesia atau Deputi Bidang Pengkajian dan Penanganan Sengketa dan Konflik Pertanahan.

Secara teknis, penanganan sengketa pertanahan oleh BPN dilakukan dengan mekanisme sebagai berikut:

1. Identifikasi

Kegiatan identifikasi dilakukan untuk mengetahui duduk permasalahan, dasar tuntutan serta tuntutan yang diajukan.

Kakan, Kakanwil dan/atau Deputi baik 
bersama-sama atau sendirisendiri melaksanakan pengkajian secara sistematik terhadap akar dan sejarah kasus pertanahan.

Hasil kajian sebagaimana dimaksud dituangkan dalam Peta Kasus Pertanahan yang menjadi dasar untuk merumuskan kebijakan umum dan/atau kebijakan teknis penanganan kasus pertanahan. Kebijakan umum dan/atau kebijakan teknis penanganan kasus pertanahan digunakan sebagai acuan untuk penanganan kasus pertanahan yang bersifat rawan, strategis, atau yang mempunyai dampak luas.

Peta Kasus Pertanahan yang telah menjadi dasar perumusan kebijakan umum dan kebijakan teknis penanganan kasus pertanahan merupakan basis data atau acuan penanganan kasus pertanahan secara sistemik, berkesinambungan dan struktural.

\section{Pengumpulan dan Pengolahan Data}

Dari hasil identifikasi tersebut dilakukan pengumpulan data yang berkaitan dengan permasalahan yang diajukan. Dalam rangka penanganan yang obyektif, dalam kegiatan ini juga diberikan kesempatan kepada pihak lawan untuk menyampaikan pendapatnya. Tidak jarang diperlukan pengumpulan data ke tempat dimana kasus/sengketa tersebut terjadi.

Pencatatan dan penyajian data kasus dilaksanakan sesuai format Daftar Isian Pengelolaan Penanganan Sengketa, Konflik dan Perkara Pertanahan.

Penyajian data kasus pertanahan berupa: a. Basis data elektronik; b. Panel data di ruang pengendalian;

c. Laporan posisi kasus pertanahan; dan

d. Laporan kepada pimpinan pada satuan organisasi.

3. Analisa dan Pembahasan

Analisa data ditempuh untuk :

a. Mengetahui apakah terdapat alasan yang cukup dari tuntutan yang bersangkutan

b. Menetapkan langkah penyelesaiannya

Dalam menganalisa diperlukan pendekatan yuridis normatif dan penerapan peraturan perundangundangan yang berlaku untuk kasus/sengketa yang bersangkutan. Ketajaman analisa dipengaruhi oleh pengetahuan dan profesionalisme aparat menjabarkan penanganan.

Pengkajian akar dan riwayat sengketa dilakukan untuk mengetahui faktor penyebab terjadinya dan potensi penyelesaian sengketa. Hasil penelitian dan analisa data sebagaimana dimaksud menghasilkan pokok permasalahan sengketa dan potensi penyelesaian sengketa. Pokok permasalahan pertanahan tersebut kemudian dilakukan telaahan hukum berdasarkan data yuridis, data fisik dan/atau data pendukung lainnya. Kemudian hasil telaahan dilakukan kajian penerapan hukum yang selanjutnya menghasilkan rekomendasi penanganan sengketa pertanahan.

c. Penyelesaian

Berdasarkan

rekomendasi 
penanganan sengketa pertanahan selanjutnya dilakukan:

1. Penelitian/pengolahan data pengaduan;

2. Penelitian lapangan;

3. Penyelenggaraan Gelar Kasus;

4. Penyusunan Risalah Pengolahan Data;

5. Penyiapan berita acara/surat/ keputusan; dan/atau

6. Monitoring dan evaluasi terhadap hasil penanganan sengketa.

Gelar Kasus sebagaimana dimaksud diselenggarakan atas perintah Deputi, Kakanwil, atau Kakan dapat dilakukan melalui persuasif, fasilitasi, mediasi para pihak dalam rangka penanganan sengketa dan jika diperlukan dapat melibatkan instansi terkait dan/atau unsur masyarakat seperti akademisi, tokoh masyarakat / adat / agama, atau pemerhati / pegiat agraria. Gelar Kasus pertanahan yang meliputi:

1. Gelar Kasus Internal;

2. Gelar Kasus;

3. Gelar Mediasi;

4. Gelar Istimewa.

Dalam hal ini sesuai dengan penelitian ini terutama akan dibahas khususnya mengenai Gelar Mediasi, yang bertujuan: menampung informasi/pendapat dari semua pihak yang berselisih, dan pendapat dari unsur lain yang perlu dipertimbangkan; menjelaskan posisi hukum para pihak baik kelemahan/ kekuatannya; memfasilitasi penyelesaian kasus pertanahan melalui musyawarah; dan pemilihan penyelesaian kasus pertanahan. Penyelenggaraan gelar mediasi merupakan upaya untuk menjamin transparansi dan ketajaman analisis; pengambilan putusan yang bersifat kolektif dan obyektif; dan meminimalisir gugatan atas hasil penyelesaian kasus.

Terdapat ketentuan pada Pasal 39 ayat (4) PerkaBPN 3/2011 bahwa Setiap Pejabat Kantor BPN RI, Kantor Wilayah Badan Pertanahan Nasional dan/atau Kantor Pertanahan yang menangani kasus pertanahan, sebelum mengambil keputusan penyelesaian kasus pertanahan harus melakukan Gelar Mediasi.

Dalam hal Gelar Mediasi tidak dapat dihadiri oleh salah satu pihak yang berselisih, pelaksanaannya dapat ditunda agar semua pihak yang berselisih dapat hadir. Apabila pihak yang berselisih sudah diundang 3 (tiga) kali secara patut tidak hadir dalam Gelar Mediasi maka mediasi tetap diselenggarakan.

\section{Peserta Gelar Mediasi}

1. Tim Pengolah;

2. Pihak pengadu, termohon dan pihak lain yang terkait;

3. Pejabat Kantor BPN RI, Kantor Wilayah Badan Pertanahan Nasional dan/atau Kantor Pertanahan dan instansi/lembaga yang terkait;

4. Pakar dan/atau saksi ahli yang terkait dengan kasus pertanahan;

5. Tim Mediator dari Kantor BPN RI, Kantor Wilayah Badan Pertanahan Nasional dan/atau Kantor Pertanahan atau eksternal BPN RI; dan

6. Unsur-unsur lain yang diperlukan.

Substansi hasil Gelar Mediasi:

1. kronologi kasus pertanahan;

2. analisis dan alternatif penyelesaian kasus pertanahan; 
3. kesimpulan hasil musyawarah kasus pertanahan; dan

4. rekomendasi dan tindak lanjut putusan Gelar Kasus.

Adapun bentuk penyelesaian yang ditempuh apabila gelar mediasi tersebut gagal dapat berupa keputusan yang mengabulkan atau menolak pengaduan tersebut, memberikan ijin, lisensi, konsesi, rekomendasi atau memberikan saran untuk mengajukan sengketa tersebut ke forum pengadilan.

\section{KEKUATAN HUKUM DARI PERJANJIAN}

Perjanjian hanya dapat dilakukan oleh para pihak yang bersama-sama sepakat dan setuju untuk melaksanakan suatu perbuatan atau hal tertentu. Oleh karenanya kedua pihak yang sudah bersepakat wajib mentaati hal yang sudah diperjanjikan, artinya kesepakatan menjadi undang-undang bagi mereka yang telah bersepakat. Jika salah satu pihak melanggar atau wanprestasi maka dianggap telah melakukan perbuatan melawan hukum.

\subsection{Pengertian Perjanjian Dan Pengaturannya}

Hukum perjanjian diatur dalam Buku III KUHPerdata yang berjudul tentang perikatan umumnya. Hubungan antara perikatan dengan perjanjian adalah bahwa perjanjian itu menerbitkan perikatan. Suatu perjanjian juga dinamakan suatu persetujuan karena dua pihak setuju untuk melaksanakan suatu hal atau sama-sama berjanji untuk melaksanakan suatu hal tertentu ${ }^{10}$.

Istilah perjanjian merupakan istilah yang sudah umum dalam dunia hukum. Mengenai pengertian perjanjian diatur dalam pasal 1313 KUHPerdata yang menyatakan bahwa suatu persetujuan adalah: "suatu perbuatan dengan mana satu orang atau lebih mengikatkan dirinya terhadap satu orang lain atau lebih".

Mengenai perbuatan tersebut para sarjana hukum perdata pada umumnya berpendapat bahwa defenisi atau batasan atau juga dapat disebut rumusan perjanjian yang terdapat di dalam ketentuan pasal 1313 KUHPerdata kurang lengkap bahkan dikatakan terlalu luas ${ }^{11}$.

Adapun kelemahan-kelemahan dapatlah dirinci ${ }^{12}$ :

1. Hanya menyangkut perjanjian sepihak saja, disini dapat diketahui dari rumusan "satu orang atau lebih mengikatkan dirinya terhadap satu orang atau lebih", "kata mengikatkan" merupakan kata kerja yang sifatnya hanya datang dari satu pihak saja tidak dari kedua belah pihak.

Adapun maksud dari perjanjian itu mengikatkan diri dari kedua belah pihak, sehingga nampak kekurangannya dimana setidak-tidaknya perlu ada rumusan "saling mengikatkan diri", jadi jelas nampak adanya konsesnsus atau kesepakatan antara kedua belah pihak yang membuat perjanjian.

2. Kata perbuatan mencakup juga perikatan tanpa consensus atau kesepakatan dalam pengertian perbuatan termasuk juga tindakan:

a. Mengurus kepentingan orang lain.

b. Perbuatan melawan hukum.

10 Subekti, R, 1984, Hukum Perjanjian, PT Intermasa, Jakarta

11 Purwahid, Azas Itikad Baik dan Kepatutan Dalam. Perjanjian, Semarang, Penerbit : FH. UNDIP, 1982

12 C.S.T. Kansil, Modul Hukum Perdata Termasuk Asas-Asas Hukum Perdata, PT. Pradnya Paramita, Jakarta, 2006 
Dalam perumusan pasal tersebut tidak disebutkan apa tujuan untuk mengadakan perjanjian sehingga pihak-pihak mengikatkan dirinya itu tidaklah jelas maksudnya. Selanjutnya untuk adanya suatu perjanjian yang dilakukan dengan tertulis dan perjanjian yang dilakukan cukup secara lisan. Untuk kedua bentuk tersebut sama kekuatannya dalam arti sama kedudukannya untuk dapat dilaksanakan oleh para pihak.

Hanya saja bila perjanjian dibuat dengan tertulis dapat dengan mudah dipakai sebagai alat bukti bila sampai terjadi persengketaan. Bila perjanjian dibuat secara lisan dan terjadi perselisihan, maka sebagai alat pembuktian akan lebih sulit, disamping harus dapat menunjukkan saksi-saksi juga itikad baik dari pihak-pihak diharapkan dalam perjanjian itu.

Dalam hal ini perjanjian mempunyai arti luas dan sempit. Dalam arti luas suatu perjanjian berarti setiap perjanjian yang menimbulkan akibat hukum sebagai yang dikehendaki atau dianggap dikehendaki oleh para pihak, termasuk di dalamnya perkawinan, perjanjian kawin dan lain-lain. Dalam arti sempit perjanjian hanya ditujukan kepada hubungan-hubungan hukum dalam lapangan hukum kekayaan saja seperti yang dimaksud oleh Buku B.W. Lebih lanjut dikemukakan bahwa undang-undang dan perjanjian sebagai sumber perikatan: bahwa perikatan, di mana perikatan sendiri dapat dirumuskan sebagai "hubungan hukum antara kedua belah pihak", di mana satu pihak ada hak dan di lain pihak ada kewajiban antara dua pihak, atau dengan perkataan lain perjanjian berisi perikatan ${ }^{13}$.

Mengenai pengertian perjanjian sampai sekarang ini belum ada keseragaman atau kesatuan pendapat diantara para ahli. Hal ini dapat dimengerti karena masing- masing sarjana itu mengemukakan pendapatnya sesuai dengan pandangannya yang dianggapnya paling tepat. Perbedaan pengertian yang diuraikan oleh para sarjana tersebut, pada dasarnya mempunyai arti yang sama, hanya saja kalimat atau susunan bahasanya berbeda. Subekti mengatakan: "bahwa perjanjian adalah suatu peristiwa di mana seorang berjanji kepada orang lain atau di mana dua orang itu saling berjanji untuk melakukan suatu hal". Dari berbagai pendapat sarjana hukum tentang arti dari perjanjian banyak mempunyai kesamaan hanya saja kalimat dan bahasanya berbeda karena hal ini dapat dimengerti masing-masing sarjana itu mengemukakan pendapatnya sesuai dengan pandangannya yang dianggap paling tepat ${ }^{14}$.

\subsection{Syarat Sahnya Perjanjian}

Dalam Kitab Undang-Undang Hukum Perdata pasal 1338 ayat (1) dikatakan Semua perjanjian yang dibuat secara sah berlaku sebagai undang-undang bagi mereka yang membuatnya. Pasal ini mengandung suatu asas kebebasan membuat perjanjian, bahwa suatu perjanjian sudah dapat terjadi dengan adanya kata sepakat para pihak yang mengikat para pihak yang membuatnya. Menurut ketentuan yang terdapat dalam pasal 1320 KUHPerdata bahwa untuk sahnya suatu perjanjian diperlukan 4 (empat) macam syarat, yaitu :

1. Sepakat mereka yang mengikatkan dirinya;

2. Kecakapan untuk membuat suatu perjanjian;

3. Mengenai suatu hal tertentu;

4. Suatu sebab yang halal.

13 Satrio, J. Cessie, Hukum Perikatan. Perikatan Yang Lahir dari Perjanjian, Buku Kedua, (Bandung, Penerbit: Citra Aditya Bakti, 1995)

14 Subekti, Kumpulan Karangan Hukum Perikatan Arbitrase dan pengadilan, (Bandung, Penerbit : Alumni, 1980). 
Syarat pertama dan kedua di atas disebut syarat subyektif, karena melekat pada diri orang yang menjadi subjek perjanjian. Jika syarat ini tidak dipenuhi, perjanjian dapat dibatalkan. Tetapi jika tidak dimintakan pembatalan kepada Hakim, perjanjian itu tetap mengikat para pihak, walaupun diancam pembatalan sebelum lampau waktu 5 (lima) tahun (pasal 1454 KUHPerdata).

Syarat ketiga dan keempat di atas disebut syarat objektif, karena mengenai suatu yang menjadi objek perjanjian. Jika syarat ini tidak dipenuhi, perjanjian batal demi hukum. Apabila sebuah perjanjian batal demi hukum, maka perjanjian itu dianggap tidak berlaku dan tidak pernah ada perikatan yang ditimbulkan dari perjanjian itu.

\subsection{Unsur-Unsur Dalam Perjanjian}

Menurut Satrio (2000:67-68) bahwa perjanjian mempunyai tiga unsur. Pertama ialah unsur essensialia yang selalu harus ada di dalam suatu perjanjian, unssur mutlak, di mana tanpa adanya unsur tersebut perjanjian tak mungkin ada. Dalam hal ini sebab yang halal merupakan unsur essensialia untuk adanya perjanjian. Dalam perjanjian jual beli harga dan barang yang disepakati kedua belah pihak harus ada.

Pada perjanjian riil, syarat penyerahan objek perjanjian merupakan essensialia, sama seperti bentuk tertentu merupakan essensialia dari perjanjian formil.

Kedua ialah unsur naturalia, perjanjian yang oleh undang-undang diatur, tetapi yang oleh para pihak dapat disingkirkan atau diganti. Dalam hal ini unsur tersebut oleh undang-undang diatur dengan hukum yang mengatur atau menambah (regelend/ aanvullend recht), seperti kewajiban penjual untuk menanggung biaya penyerahan dan untuk menjamin dapat disimpangi atas kesepakatan kedua belah pihak.

Ketiga unsur accidentalia, unsur perjanjian yang ditambahkan oleh para pihak. Dalam hal ini undang-undang sendiri tidak mengatur tentang hal tersebut, seperti di dalam suatu perjanjian jual beli, benda-benda tertentu dapat dikecualikan.

\subsection{Pelaksanaan Perjanjian}

Suatu perjanjian, merupakan suatu peristiwa di mana seorang berjanji kepada orang lain, atau di mana dua orang saling berjanji untuk melaksanakan sesuatu. Melihat macamnya hal yang dijanjikan untuk dilaksanakan, perjanjian-perjanjian itu dibagi dalam 3 (tiga) macam, yaitu:

1. Perjanjian untuk memberikan/ menyerahkan suatu barang.

2. Perjanjian untuk berbuat sesuatu.

3. Perjanjian untuk tidak berbuat sesuatu ${ }^{15}$.

Hal yang harus dilaksanakan itu dinamakan prestasi. Perjanjian untuk memberikan/ menyerahkan suatu barang, misalnya: jual beli, tukar menukar, penghibahan (pemberian), sewa menyewa, pinjam pakai. Perjanjian untuk memberikan sesuatu, misalnya: perjanjian untuk membuat suatu lukisan, perjanjian perburuhan, perjanjian untuk membuat sebuah garasi mobil, dan lain sebagainya.

Perjanjian untuk tidak berbuat sesuatu, misalnya: perjanjian untuk tidak mendirikan tembok, perjanjian untuk tidak mendirikan suatu perusahaan yang sejenis dengan kepunyaan seorang lain, dan lain sebagainya. Suatu persoalan dalam Hukum Perjanjian, adalah apakah jika si berutang (si debitur)

15 Bandung 
tidak menepati janjinya, si berpiutang (si kreditur) dapat mewujudkan sendiri prestasi yang dijanjikan itu. Artinya: Apakah si berpiutang (kreditur) dapat dikuasakan oleh hakim untuk mewujudkan atau merealisasikan sendiri apa yang menjadi haknya menurut perjanjian? Jika yang demikian itu mungkin, maka dikatakan perjanjian tadi dapat di-eksekusikan secara riil. Meskipun selalu ada kemungkinan untuk mendapatkan suatu ganti rugi, tetapi bila seseorang mendapat apa yang dijanjikan, itu adalah yang paling memuaskan. Dari itu apa yang dijanjikan dinamakan prestasi primair, sedangkan ganti rugi dinamakan prestasi subsidair.

Kitab Undang-Undang Hukum Perdata (KUHPerdata), memberikan sekedar petunjuk dalam menjawab persoalan tersebut diatas. Mengenai perjanjianperjanjian yang disebutkan diatas tadi, yang tergolong kedalam perjanjian untuk berbuat sesuatu (melakukan suatu perbuatan) dan perjanjian untuk tidak berbuat sesuatu (tidak melakukan suatu perbuatan) terdapat dalam pasal 1240 dan 1241 KUHPerdata. Mengenai perjanjian-perjanjian seperti inilah disebutkan bahwa eksekusi riil itu mungkin dilaksanakan. Pasal 1240 menyebutkan tentang perjanjian untuk tidak berbuat sesuatu (tidak melakukan suatu perbuatan), bahwa si berpiutang (kreditur) berhak menuntut penghapusan segala sesuatu yang telah dibuat berlawanan dengan perjanjian dan bolehlah ia minta supaya dikuasakan oleh hakim untuk menyuruh menghapuskansegala sesuatu yang telah dibuat tadi di atas biaya si berutang(debitur), dengan tidak mengurangi haknya untuk menuntut ganti rugi, jika ada alasan untuk itu. Dan pasal 1241 menerangkan tentang perjanjian untuk berbuat sesuatu (melakukan suatu perbuatan), bahwa apabila perjanjian tidak dilaksanakan (artinya: apabila si berutang tidak menepati janjinya), maka si berpiutang (kreditur) boleh juga dikuasakan supaya dia sendiri yang mengusahakan pelaksanaannya atas biaya si berutang (debitur). Mengenai perjanjian untuk tidak melakukan suatu perbuatan, memang dalam perjanjian semacam itu, bila janji dilanggar maka perjanjian dapat di batalkan. Perusahaan yang dibuka atau didirikan melanggar perjanjian, dapat ditutup. Pihak yang berkepentingan (kreditur) tentunya juga dapat meminta kepada pengadilan, supaya ditetapkan sejumlah uang paksa untuk mendorong si debitur supaya ia meniadakan apa yang sudah diperbuat itu. Dan juga ia dapat meminta supaya orang yang melanggar perjanjian itu dihukum untuk membayar sejumlah uang sebagai ganti rugi, tetapi sudah barang tentu tiada sesuatu yang lebih memuaskan baginya daripada penghukuman si pelanggar perjanjian itu untuk meniadakan segala apa yang telah diperbuat itu.

Perjanjian untuk berbuat sesuatu (melakukan suatu perbuatan) juga secara mudah dapat dijalankan secara riil, asal saja bagi si berpiutang (kreditur) tidak penting oleh siapa perbuatan itu akan dilakukan, misalnya membuat sebuah garasi mobil, yang dengan mudah dapat dilakukan oleh orang lain. Kalau yang harus dibuat itu lukisan, sudah barang tentu perbuatan itu tidak dapat dilakukan oleh orang lain selain pelukis yang menjanjikan akan membuat lukisan tersebut. Karena itu perjanjian untuk melakukan suatu perbuatan yang bersifat sangat pribadi, tidak dapat dilaksanakan secara riil, apabila pihak yang menyanggupi melakukan perbuatan tersebut tidak menepati janjinya.

Mengenai perjanjian untuk memberikan (menyerahkan) suatu barang, tidak terdapat sesuatu petunjuk dalam undang-undang. 
Mengenai barang yang tak tertentu, (artinya barang yang sudah disetujui atau dipilih) dapat dikatakan bahwa para ahli hukum dan yurisprudensi sependapat bahwa eksekusi riil itu dapat dilakukan, misalnya jual beli suatu barang bergerak yang tertentu. Jika mengenai barang yang tak tertentu, eksekusi riil tidak mungkin dilakukan.

Mengenai barang tak bergerak ada 2 (dua) pendapat. Yurisprudensi pada waktu sekarang dapat dikatakan masih menganut pendirian bahwa eksekusi riil tidak mungkin dilakukan. Pendirian itu didasarkan pada 2 (dua) alasan.

Pertama: Untuk menyerahkan hak milik atas suatu benda tak bergerak, diperlukan suatu akta transport yang merupakan suatu akta bilateral, yang harus diselenggarakan oleh dua pihak dan karena itu tidak mungkin diganti dengan suatu vonis atau putusan hakim. Penyerahan hak atau peralihan hak tidak hanya berdasar perjanjian para pihak saja tetapi juga karena putusan pengadilan yang telah mempunyai hukum tetap untuk dijalankan. Hal ini terdapat dalam Peraturan Pemerintah No.24 Tahun 1997 Tentang Pendaftaran Tanah pasal 55 ayat (1):

Panitera Pengadilan wajib memberitahukan kepada Kepala Kantor Pertanahan mengenai isi semua putusan Pengadilan yang telah memperoleh kekuatan hukum tetap dan penetapan Ketua Pengadilan yang mengakibatkan terjadinya perubahan pada data mengenai bidang tanah yang sudah didaftar atau satuan rumah susun untuk dicatat pada buku tanah yang bersangkutan dan sedapat mungkin pada sertipikatnya dan daftar-daftar lainnya.

Kedua: Alasan a contrario, yaitu dalam pasal 1171 ayat (3) KUHPerdata, ditetapkan (mengenai hipotik), bahwa barang siapa yang berdasarkan undang-undang atau perjanjian, diwajibkan memberikan hipotik, dapat dipaksa untuk itu dengan putusan hakim yang mempunyai kekuatan yang sama, seolah-olah ia telah memberikan persetujuannya untuk hipotik itu, dan yang dengan terang akan menunjuk benda-benda atas mana akan dilakukan pembukuan. Dikatakan, bahwa oleh karena untuk hipotik tetapi bercidera janji, sedangkan dalam hal seseorang yang wajib menyerahkan hak milik atas suatu benda tak begerak tidak ada aturannya, bahwa untuk yang terakhir ini tiada suatu emungkinan untuk melaksanakan suatu eksekusi riil ${ }^{16}$.

Seperti sudah dikatakan, ada juga sarjanasarjana yang berpendapat lain, yaitu menganggap bahwa dalam hal perjanjian untuk menyerahkan suatu benda tidak bergerak itu dapat dilakukan eksekusi riil terhadap pihak yang tidak menepati janjinya untuk menyerahkan benda tersebut. Mereka ini menganut pendirian, bahwa bila oleh undang-undang tidak ditetapkan sebaliknya, maka suatu hak yang diperoleh dari sesuatu perjanjian pada asasnya dapat direalisasikan, asal tidak bertentangan dengan sifat perjanjian.

Untuk melaksanakan suatu perjanjian, lebih dahulu harus ditetapkan secara tugas dan cermat apa saja isi perjanjian tersebut, atau dengan kata lain, apa saja hak dan kewajiban masing-masing pihak. Bisasanya orang mengadakan suatu perjanjian dengan tidak mengatur atau menetapkan secara teliti hak dan kewajiban mereka. Mereka itu hanya menetapkan hal-hal yang pokok dan penting saja. Dalam jual beli misalnya, hanya ditetapkan tentang barang mana yang dibeli, jenis, jumlah dan harganya. Tidak ditetapkan tentang tempat penyerahan

16 Jakarta 
barang, biaya pengantaran, tempat dan waktu pembayaran, bagaimana kalau barang musnah di perjalanan dan lain sebagainya.

Menurut pasal 1339 KUHPerdata, "suatu perjanjian tidak hanya mengikat untuk halhal yang dengan tegas dinyatakan dalam perjanjian, tetapi juga untuk segala sesuatu yang menurut sifat perjanjian diharuskan (diwajibkan) oleh kepatutan, kebiasaan dan undang-undang". Dengan demikian, setiap perjanjian diperlengkapi dengan aturanaturan yang terdapat dalam undang-undang, dalam adat kebiasaan (di suatu tempat dan di suatu kalangan tertentu), sedangkan kewajiban-kewajiban yang diharuskan oleh kepatutan (norma-norma kepatutan) harus juga diindahkan.

Kita melihat dalam pasal 1339 tersebut, bahwa adat kebiasaan telah ditunjuk sebagai sumber norma di samping undang-undang ikut menentukan hak-hak dan kewajibankewajiban kedua belah pihak dalam suatu perjanjian. Suatu persoalan disini, bila terdapat suatu adat kebiasaan yang berlainan atau menyimpang dari undang-undang, apakah peraturan perundang-undangan masih berlaku ataukah ia sudah disingkirkan oleh adat istiadat tersebut? Jawabannya adalah bahwa suatu pasal (peraturan) undang-undang, meskipun sudah ada suatu adat kebiasaan yang menyimpang, masih tetap berlaku dan barang siapa pada suatu hari menunjuk pada peraturan perundangundangan tersebut, harus dibenarkan dan tidak boleh dipersalahkan.

Lain halnya, dengan apa yang lazim dinamakan standard clausula. Ini oleh Pasal 1347 KUHPerdata dimasukkan dalam halhal yang selalu diperjanjikan. Menurut pasal tersebut, hal-hal yang selalu diperjanjikan menurut kebiasaan dianggap secara diam- diam dimasukkan dalam perjanjian, meskipun tidak dengan tegas dinyatakan. Oleh karena dianggap sebagai diperjanjikan atau sebagai bagian dari perjanjian sendiri, maka hal yang menurut kebiasaan selalu diperjanjikan itu dapat menyingkirkan suatu pasal undangundang yang merupakan hukum pelengkap. Dalam hubungan ini, terkenal lagi suatu perkara (terjadi di Negeri Belanda) mengenai jual beli sapi. Persoalannya, mengenai risiko atas seekor sapi yang telah dijual, tetapi belum diserahkan kepada pembelinya. Sebagaimana kita ketahui dalam suatu perjanjian jual beli, resiko atas barang yang sudah dibeli tetapi belum diserahkan itu, bila mengenai suatu barang tertentu, dipikulkan atas pundak pihak pembeli. Artinya: kalau barang itu musnah diluar kesalahan seseorang, maka pembeli harus tetap membayar harganya, meskipun ia belum menerima barangnya. Dalam perkara yang bersangkutan ini, sapi yang telah dijual dan belum diserahkan itu mati. Ketika pembeli ditagih tentang pembayarannya, ia mengemukakan bahwa dikalangan para pedagang sapi sudah lazim dalam jual beli sapi bahwa selama sapi masih ditangan si penjual, resiko atas sapi itu masih dipikul oleh si penjual. Benar dalam jual beli sapi yang bersangkutan ini hal itu tidak secara tegas dinyatakan, tetapi harus dianggap secara diam-diam dimasukkan dalam perjanjian. Setelah pihak pembeli berhasil membuktikan tentang adanya janji yang lazim dipakai itu, ia dibenarkan oleh hakim.

Apabila sesuatu hal tidak diatur dalam undang-undang dan belum juga ada dalam kebiasaan, karena mungkin belum atau tidak begitu banyak dihadapi dalam praktek, maka haruslah diciptakan suatu penyelesaian dengan berpedoman pada kepatutan.

Sebagai kesimpulan dari apa yang dibicarakan diatas, dapat ditetapkan bahwa ada 3 (tiga) 
sumber norma yang ikut mengisi suatu perjanjian, yaitu: Undang-undang, kebiasaan dan kepatutan.

Menurut Pasal 1338 ayat (3) KUHPerdata, semua perjanjian itu harus dilaksanakan dengan itikad baik (dalam bahasa Belanda disebut tegoeder trouw ; dalam bahasa Inggris disebut in good faith, dalam bahasa Perancis disebut de bonne foi). Norma yang dituliskan di atas ini merupakan salah satu sendi yang terpenting dari Hukum Perjanjian.

\subsection{Asas-asas perjanjian}

Asas-asas perjanjian diatur dalam KUHPerdata, yang sedikitnya terdapat 5 asas yang perlu mendapat perhatian dalam membuat perjanjian: asas kebebasan berkontrak (freedom of contract), asas konsensualisme (concsensualism), asas kepastian hukum (pacta sunt servanda), asas itikad baik (good faith) dan asas kepribadian (personality).

\section{Asas Kebebasan Berkontrak (freedom of} contract)

Setiap orang dapat secara bebas membuat perjanjian selama memenuhi syarat sahnya perjanjian dan tidak melanggar hukum, kesusilaan, serta ketertiban umum. Menurut Pasal 1338 ayat (1) KUH Perdata, "Semua perjanjian yang dibuat secara sah berlaku sebagai undang-undang bagi mereka yang membuatnya." "Semua perjanjian..." berarti perjanjian apapun, diantara siapapun. Tapi kebebasan itu tetap ada batasnya, yaitu selama kebebasan itu tetap berada di dalam batas-batas persyaratannya, serta tidak melanggar hukum (undang-undang), kesusilaan (pornografi, pornoaksi) dan ketertiban umum (misalnya perjanjian membuat provokasi kerusuhan).
2. Asas Kepastian Hukum (Pacta Sunt Servanda)

Jika terjadi sengketa dalam pelaksanaan perjanjian, misalnya salah satu pihak ingkar janji (wanprestasi), maka hakim dengan keputusannya dapat memaksa agar pihak yang melanggar itu melaksanakan hak dan kewajibannya sesuai perjanjian bahkan hakim dapat memerintahkan pihak yang lain membayar ganti rugi. Putusan pengadilan itu merupakan jaminan bahwa hak dan kewajiban para pihak dalam perjanjian memiliki kepastian hukum secara pasti memiliki perlindungan hukum.

\section{Asas Konsensualisme (concensualism)}

Asas konsensualisme berarti kesepakatan (consensus), yaitu pada dasarnya perjanjian sudah lahir sejak detik tercapainya kata sepakat. Perjanjian telah mengikat begitu kata sepakat dinyatakan dan diucapkan, sehingga sebenarnya tidak perlu lagi formalitas tertentu. Pengecualian terhadap prinsip ini adalah dalam hal undang-undang memberikan syarat formalitas tertentu terhadap suatu perjanjian, misalkan syarat harus tertulis - contoh, jual beli tanah merupakan kesepakatan yang harus dibuat secara tertulis dengan akta otentik Notaris.

4. Asas Itikad Baik (good faith/tegoeder trouw)

Itikad baik berarti keadaan batin para pihak dalam membuat dan melaksanakan perjanjian harus jujur, terbuka, dan saling percaya. Keadaan batin para pihak itu tidak boleh dicemari oleh maksudmaksud untuk melakukan tipu daya atau menutup-nutupi keadaan sebenarnya.

\section{Asas Kepribadian (personality)}

Asas kepribadian berarti isi perjanjian hanya mengikat para pihak secara 
personal - tidak mengikat pihakpihak lain yang tidak memberikan kesepakatannya. Seseorang hanya dapat mewakili dirinya sendiri dan tidak dapat mewakili orang lain dalam membuat perjanjian. Perjanjian yang dibuat oleh para pihak hanya berlaku bagi mereka yang membuatnya.

\section{6. "Syarat Batal" Perjanjian}

Dalam banyak praktek membuat surat perjanjian sering dimajukan klausul sebagai berikut: jika salah satu pihak tidak melaksanakan kewajibannya, maka pihak yang lain dapat membatalkan perjanjian. Sebenarnya klausul semacam ini tidak perlu dimasukan kedalam perjanjian, karena hukum perdata telah menerapkan prinsip umum dalam perjanjian berupa syarat batal. Suatu syarat batal dianggap selalu dicantumkan dalam perjanjian (semua perjanjian) apabila salah satu pihak tidak melaksanakan kewajibannya.

\section{Pasal 1266 KUHPerdata:}

"Syarat batal dianggap selalu dicantumkan dalam persetujuan yang timbal balik, andai kata salah satu pihak tidak memenuhi kewajibannya.

Syarat batal merupakan suatu batasan, dimana jika salah satu pihak tidak melaksanakan kewajibannya dalam perjanjian (wanprestasi), maka pihak yang lain dalam perjanjian itu dapat membatalkan perjanjian secara sepihak (tanpa persetujuan pihak yang wanprestasi). Klausul semacam ini dianggap selalu ada dalam setiap perjanjian, sehingga meskipun suatu perjanjian tidak menentukannya dalam bunyi pasal-pasalnya, prinsip ini tetap berlaku.

Tentu saja keberlakuan prinsip ini tidak serta merta. Meskipun syarat batal dianggap selalu berlaku pada semua perjanjian, namun batalnya perjanjian itu tidak dapat terjadi begitu saja, melainkan harus dimintakan pembatalannya kepada pengadilan. Pihak yang menuduh pihak lainnya wanprestasi, harus mengajukan pembatalan itu kepada pengadilan. Tanpa adanya putusan pengadilan yang menyatakan bahwa salah satu pihak telah wanprestasi dan karenanya perjanjian dibatalkan, maka bisa dikatakan tidak ada perjanjian yang batal.

Dalam banyak perjanjian pula pasal 1266 KUHPerdata tersebut seringkali dikesampingkan. Dalam praktek, banyak perjanjian memasukan klausul sebagai berikut: perjanjian ini mengesampingkan berlakunya pasal 1266 dan 1267 KUHPerdata.

Maksud dari klausul tersebut adalah agar para pihak dapat membatalkan perjanjiannya secara sepihak tanpa perlu mengajukan pembatalan melalui pengadilan. Karena pasal 1266 KUHPerdata berlaku secara mutlak, maka percuma saja memasukan klausul tersebut karena ujung-ujungnya pembatalan itu harus ditempuh juga lewat pengadilan.

\subsection{Dading}

Dading atau perdamaian diatur dalam pasal 1851 - 1864 KUHPerdata.

Perdamaian dirumuskan dalam pasal 1851 sebagai suatu persetujuan dengan mana kedua belah pihak, dengan menyerahkan, menjanjikan atau menahan suatu barang, mengakhiri suatu perkara yang sedang bergantung ataupun mencegah timbulnya suatu perkara.

Berdasarkan hal tersebut, perjanjian perdamaian yang dihasilkan dari suatu proses penyelesaian sengketa harus dituangkan dalam bentuk tertulis, hal tersebut bertujuan 
untuk mencegah munculnya kembali sengketa yang sama di kemudian hari. Untuk memenuhi hal tersebut di atas maka proses perdamaian di luar pengadilan dapat dilaksanakan dengan membuat suatu akta yaitu akta perdamaian. Akta perdamaian ini dapat berupa akta di bawah tangan maupun akta otentik yang dibuat oleh seorang notaris.

Pada dasarnya siapa saja dapat menjadi subyek dari perjanjian perdamaian sebagaimana diatur dalam Pasal 1852 KUHPerdata yang berbunyi :

"Untuk mengadakan suatu perdamaian diperlukan bahwa seorang mempunyai kekuasaan untuk melepaskan haknya atas hal-hal yang termaktub dalam perdamaian itu. Wali-wali dan pengampu-pengampu tidak dapat mengadakan suatu perdamaian selain jika mereka bertindak menurut ketentuan dari bab kelima belas dan ketujuh belas dari buku kesatu Kitab Undang-Undang ini. Kepala-kepala daerah yang bertindak sebagai demikian, begitu pula lembagalembaga umum tidak dapat

mengadakan suatu perdamaian dengan mengindahkan acara-acara yang ditetapkan dalam perundang-undangan yang mengenai mereka.

Dalam akta perdamaian terdapat dua istilah yaitu Acte Van Dading dan Acte Van Vergelijk Retnowulan Sutantio menggunakan istilah Acte Van Dading untuk perdamaian 4 Sedangkan Tresna menggunakan istilah Acte Van Vergelijk untuk menyatakan perdamaian dalam Pasal $130 \mathrm{HIR}^{17}$.

Dari uraian di atas maka dapat dikemukakan bahwa perdamaian dapat dibagi sebagai berikut:

a) Akta perdamaian yang dibuat dengan persetujuan hakim, dimana akta itu dibuat oleh para pihak dihadapan hakim atau dengan mediator maupun fasilitator hakim atau yang sering disebut dengan Acte Van Vergelijk.

b) Akta perdamaian tanpa persetujuan hakim yang dilakukan dengan Alternatif Penyelesaian Sengketa ( APS ) atau yang biasa disebut juga Alternative Dispute Resolution ( ADR ) dapat menggunakan Acta Van Dading maupun akta di bawah tangan.

Mengenai kekuatan hukum perjanjian perdamaian, pasal 1858 ayat 1 KUHPerdata menyebutkan segala perdamaian mempunyai diantara para pihak suatu kekuatan seperti putusan hakim dalam tingkat yang penghabisan. Adapun Putusan Mahkamah Agung Republik Indonesia tanggal 9 januari 1974 menurunkan abstraksi hukum, "berdasarkan pasal 1858 BW suatu perdamaian/dading di muka sidang Pengadilan Negeri mempunyai kekuatan yang sama dengan putusan Pengadilan dalam tingkat akhir dan tidak dapat dibatalkan dengan alasan adanya kerugian"18.

Dalam perdamaian perlu juga diperhatikan asas Judicata Habitur yaitu asas yang menyatakan bahwa tidak boleh terjadi dua kali pemutusan terhadap suatu kasus yang sama antara kedua belah pihak yang sama pula.

\subsection{Eksekusi Grosse Akta}

Sesuai Pasal 224 HIR/Pasal 258 RBg ada dua macam grosse yang mempunyai kekuatan eksekutorial, yaitu grosse akta pengakuan hutang dan grosse sita hipotik. Grosse adalah salinan pertama dan akta otentik. Salinan pertama ini diberikan kepada kreditur. Oleh karena salinan pertama dan alas pengakuan

17 M.R. Tresna, Komentar HIR, ( Jakarta : Pradnya Paramita, 1975), hal. 130

18. Proyek Yurisprudensi Mahkamah Agung, rangkuman Yurisprudensi Mahkamah Agung Indonesia II dan Acara Perdata, Jakarta 1977, hal 150-151. 
hutang yang dibuat oleh Notaris mempunyai kekuatan eksekusi, maka salinan pertama ini harus ada kepala/ irah-irah yang berbunyi "Demi Keadilan Berdasarkan Ketuhanan Yang Maha Esa". Salinan lainnya yang diberikan kepada debitur tidak memakai kepala/ irahirah Demi Keadilan Berdasarkan Ketuhanan Yang Maha Esa. Asli dari akta (minit) disimpan oleh Notaris dalam arsip dan tidak memakai kepala/ irah-irah.

Pasal 224 HIR adalah sebagai berikut:

"Surat asli dari pada surat hipotik dan surat utang, yang dibuat di hadapan notaris di Indonesia dan yang memakai perkataan: "atas nama keadilan" di kepalanya, kekuatannya sama dengan surat putusan hakim. Dalam hal menjalankan surat yang demikian, jika tidak dipenuhi dengan jalan damai, maka dapat diperlakukan peraturan pada bagian ini, akan tetapi dengan pengertian, bahwa paksa badan hanya boleh dilakukan sesudah diizinkan oleh putusan Hakim. Jika hal menjalankan putusan itu harus dijalankan sama sekali atau sebagian di luar daerah hukum pengadilan negeri, yang ketuanya memerintahkan menjalankan itu, maka peraturan-peraturan pada pasal 195 ayat kedua dan yang berikutnya dituruti."

Dalam hal ini, agaknya cukup jelas bahwa grosse akta, apabila tidak dipenuhi secara baik-baik oleh debitur, dapat langsung dieksekusi oleh kreditur, dengan meminta fiat (perintah) eksekusi dari Ketua Pengadilan Negeri. Artinya, jawaban atas kedua pertanyaan tersebut di atas juga tidak begitu sulit dijawab, yaitu bahwa grosse akta dapat langsung dieksekusi sebagaimana layaknya putusan hakim, serta mekanisme eksekusinya mengikuti eksekusi putusan hakim sebagaimana tersebut dalam HIR, yaitu dengan peringatan kepada debitur, penyitaan, dan penjualan.

\section{KERANGKA PEMIKIRAN}

Penelitian ini dilandasi pada fakta sengketa dan konflik pertanahan yang terus meningkat baik di tingkat pengaduan atau pelaporan dari masyarakat sampai kepada sengketa dan konflik pertanahan yang ditangani melalui lembaga peradilan, baik Pengadilan Negeri, Pengadilan Tinggi, PTUN maupun Mahkamah Agung. Meningkatnya sengketa dan konflik pertanahan tersebut antara lain disebabkan faktor internal yang bersumber dari pelayanan pertanahan termasuk administrasi pertanahan dan faktor eksternal yang bersumber dari masyarakat dan instansi terkait seperti Desa/Kelurahan, Camat, PPAT, KP-PBB dsb.

Sengketa dan konflik yang melalui jalur Pengadilan/litigasi tentunya menempuh proses yang cukup panjang karena dalam sistem hukum di Indonesia, satu kasus yang sudah menang di tingkat peradilan umum dapat kemudian digugat di Peradilan Tata Usaha Negara, yang akhir nya menunggu penetapan terakhir yaitu Peninjauan kembali yang merupakan upaya hukum terakhir. Kondisi ini tidak hanya menghabiskan waktu tetapi juga uang dan tenaga sehingga penggunaan jalur non litigasi dalam penyelesaian sengketa dan konflik pertanahan sangat tepat untuk dilakukan. Ada banyak keuntungan yang diperoleh para pihak dari proses penyelesaian melalui mediasi antara lain adalah proses lebih sederhana dibandingkan di pengadilan, hemat biaya dan upaya penyelesaian secara win-win solution.

Secara umum kerangka pemikiran penelitian ini disajikan pada Gambar 2.1. Kerangka Pikir Penelitian 


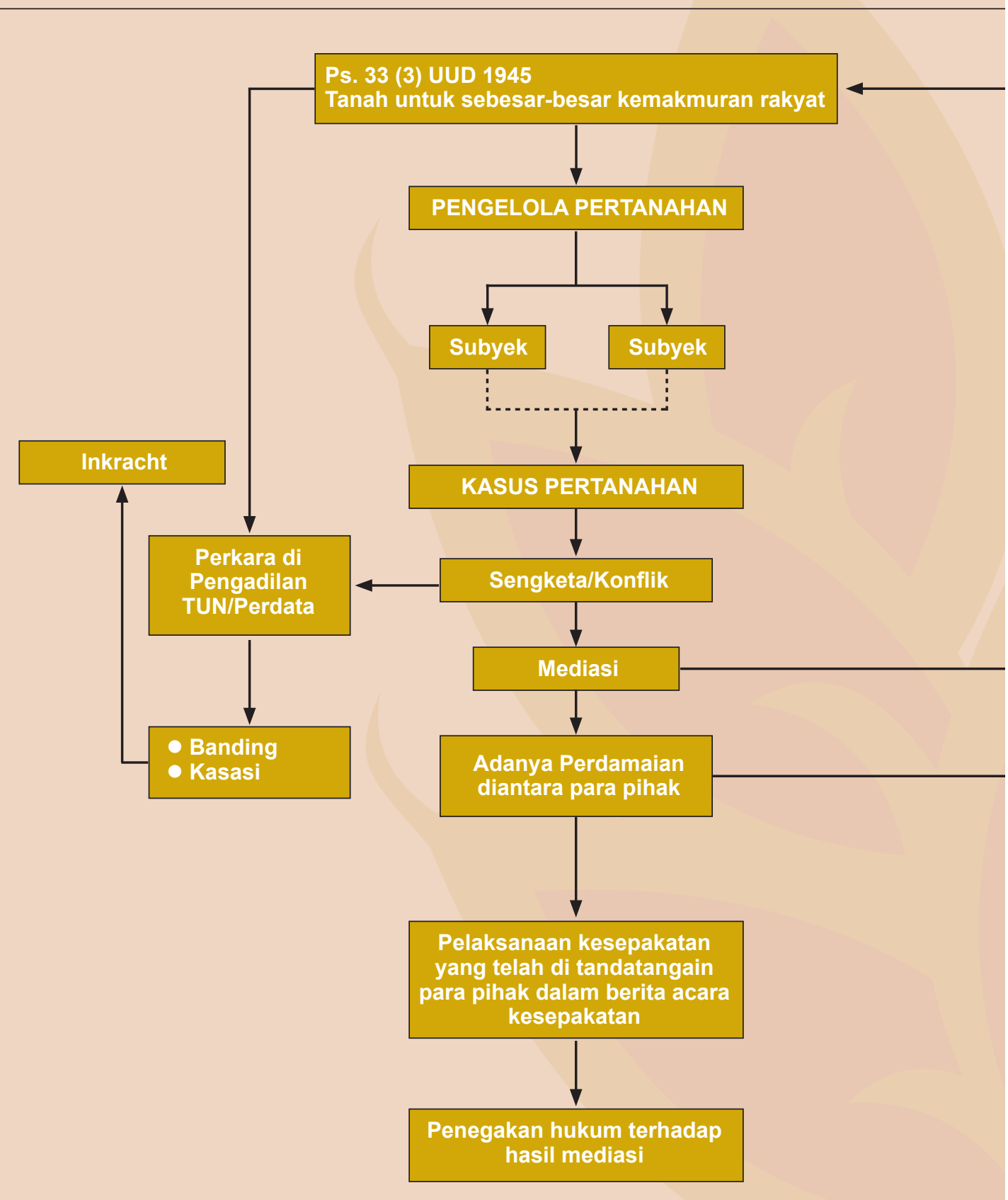

Gambar 2.1. Kerangka Pikir Penelitian 


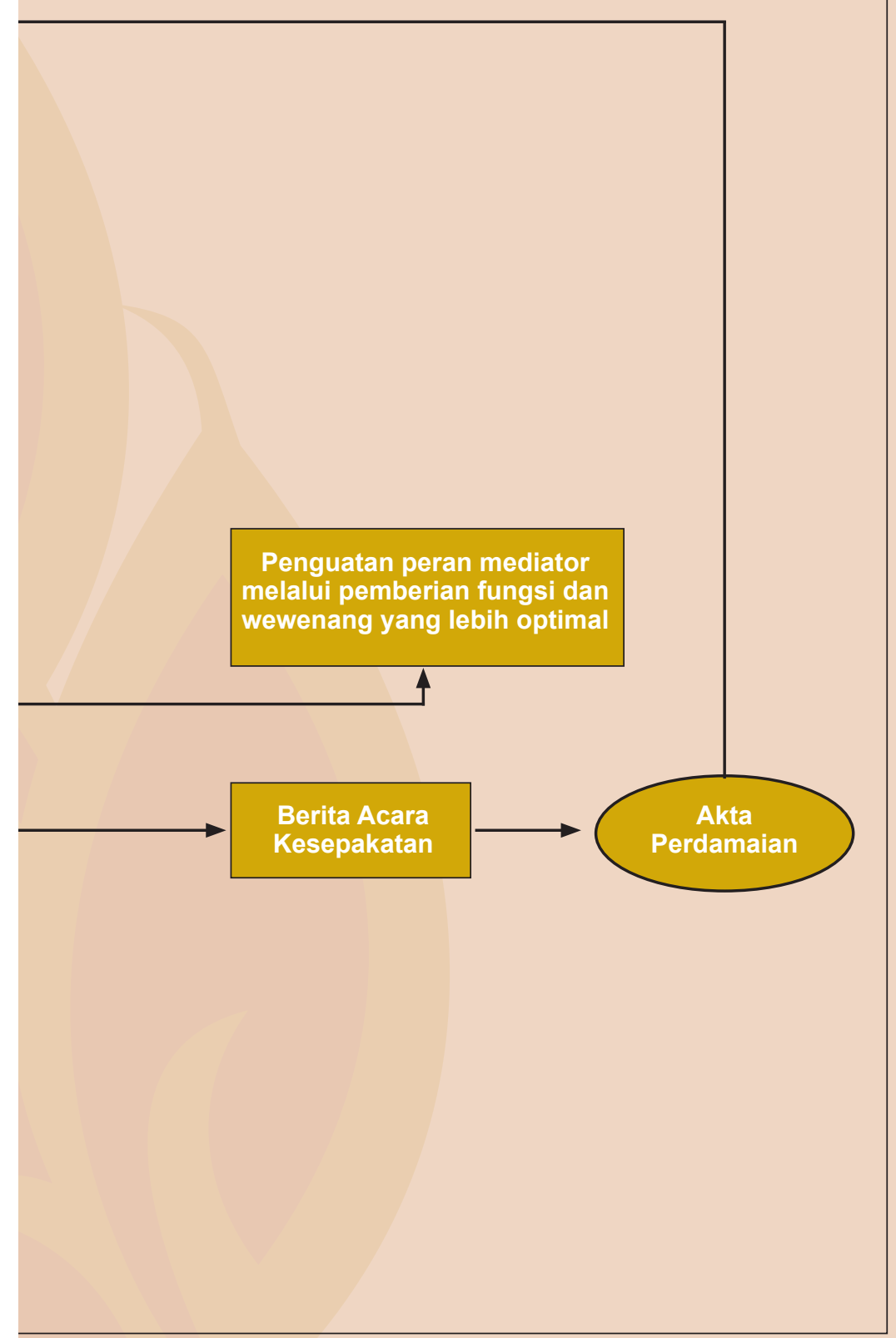




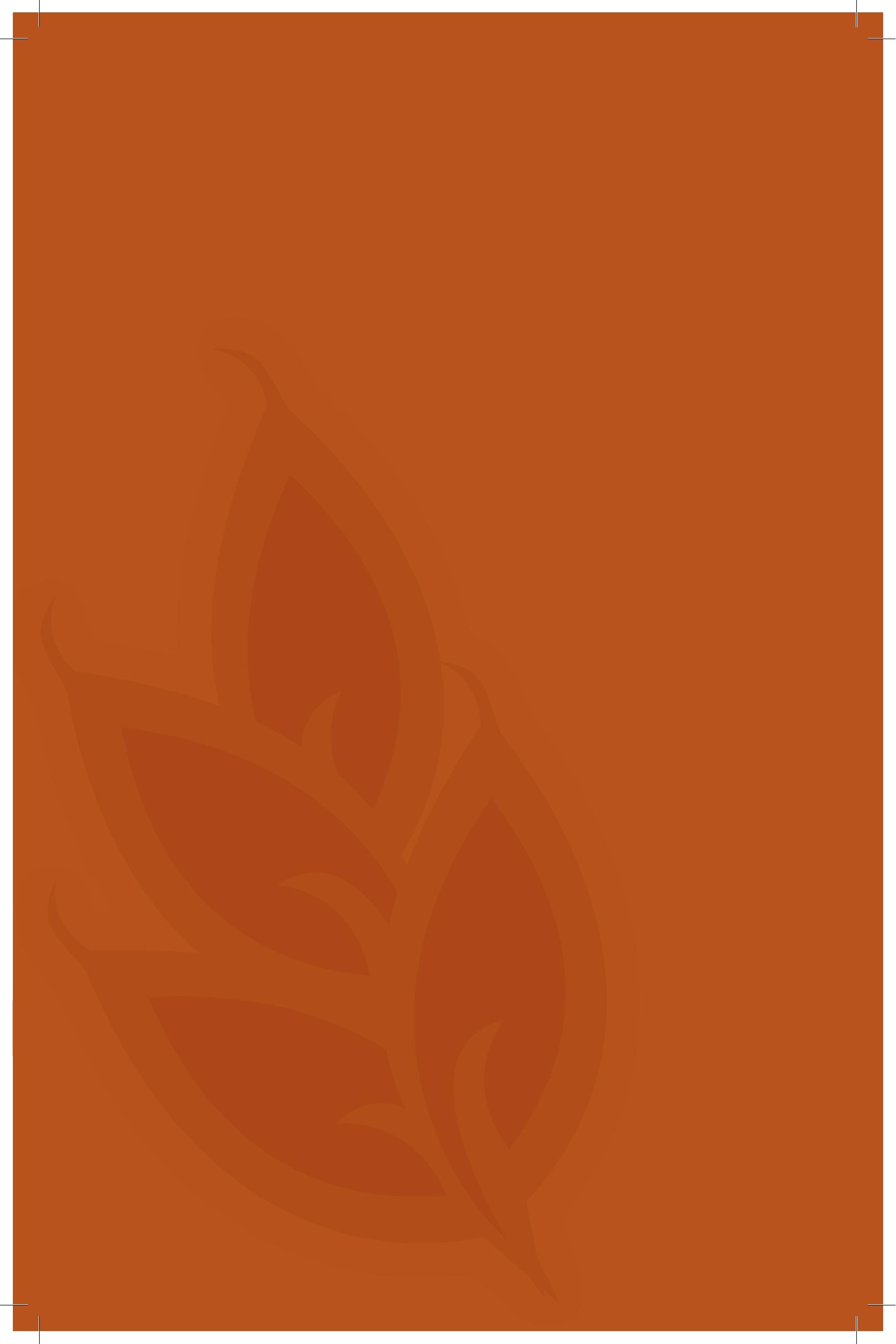





\section{BAB III \\ METODE PENELITIAN}

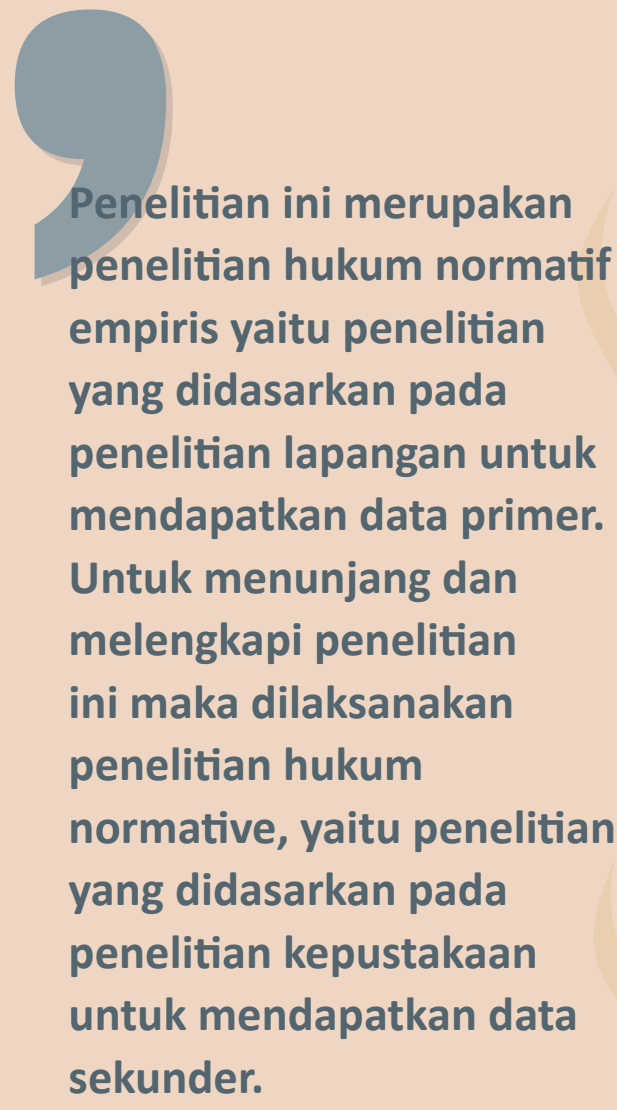

\section{TIPE PENELITIAN}

Penelitian hukum merupakan suatu kegiatan ilmiah, yang didasarkan pada metode, sistematika dan pemikiran tertentu, yang bertujuan untuk mempelajari satu atau beberapa gejala hukum tertentu, dengan jalan menganalisanya ${ }^{1}$. Penelitian hukum yang dilakukan yang dilakukan dengan cara meneliti bahan pustaka atau data sekunder belaka, dapat dinamakan penelitian hukum normatif atau atau penelitian hukum kepustakaan (disamping adanya penelitian hukum sosiologis atau empiris yang terutama meneliti data primer) ${ }^{2}$.

Penelitian kepustakaan dapat berdiri sendiri tanpa disertai atau dilengkapi dengan penelitian lapangan. Penelitian hukum dapat semata-mata hanya mendasarkan pada penelitian kepustakaan saja (penelitian hukum normatif). Akan tetapi penelitian kepustakaan itu dapat dilengkapi dengan penelitian lapangan ${ }^{3}$.

\section{LOKASI PENELITIAN}

Pelaksanaan kegiatan ini dilakukan di 5 Provinsi yaitu Maluku, Lampung, Kalimantan Selatan, NTB dan Jawa Barat.

\section{RESPONDEN/INFORMAN PENELITIAN}

1. Kantor Wilayah : Kepala Kantor Wilayah dan Kepala Bidang V

2. Kantor Pertanahan : Kepala Kantor Pertanahan dan Kepala Seksi V dan Kasubsi

3. Pemerintah Daerah

4. LSM

1. Soerjono Soekanto, Pengantar Penelitian Hukum, Cetakan ketiga, Penerbit Universitas Indonesia, Jakarta, Indonesia, 1986.

2. Soerjono Soekanto dan Sri Mamudji, Penelitian Hukum Normatif, cetakan kelima, Raja Grafindo Perkasa, Jakarta, 2001.

3. Sudikno Mertokusumo, Penemuan Hukum Sebuah Pengantar, cetakan pertama, liberty, Yogyakarta, 2000. 


\section{JENIS DATA}

1. Data yang digunakan adalah data sekunder dan data primer. Data sekunder berupa: (1) daftar konflik yang terjadi di wilayah provinsi, (2) daftar pelaksanaan mediasi di wilayah provinsi dan kota/kabupaten (3) peraturan perundangan atau kebijakan yang telah dikeluarkan untuk penanganan sengketa di wilayah provinsi dan kota/ kabupaten,(4) data pelaksanaan tindak lanjut penanganan oleh Kantor Wilayah BPN Provinsi dan Kantor Pertanahan Kabupaten. Data sekunder diperoleh dari Kantor Wilayah BPN Provinsi, Kantor Pertanahan Kota/Kabupaten, Pemerintah Daerah, dan LSM setempat.

2. Data primer dilakukan dengan cara memperoleh informasi melalui Focus Group Discussion (FGD) dan melalui kuesioner yang diisi oleh Kepala Kantor Wilayah BPN Provinsi, Kabid dan Kasi serta Kepala Kantor Pertanahan Kabupaten/ Kota, Kasi dan Kasubsi.

\section{ANALISA DATA}

Penelitian ini menggunakan metode analisis deskriptif kualitatif dengan langkah-langkah sebagai berikut ;

1. Melakukan observasi ke masing-masing kantor pertanahan yang menjadi lokasi sampel;

2. Mendeskripsikan semua temuan dalam kegiatan observasi (data primer dan sekunder);

3. Melakukan penajaman terhadap hasil deskripsi temuan dengan cara melalui diskusi dengan para pihak yang terkait;

4. Membuat profil kasus pertanahan, mediator dan wewenangnya serta menyusun tahapan pelaksanaan mediasi dari awal sampai terjadi kesepakatan dan tindak lanjutnya serta peningkatan peran mediator agar lebih efektif. 


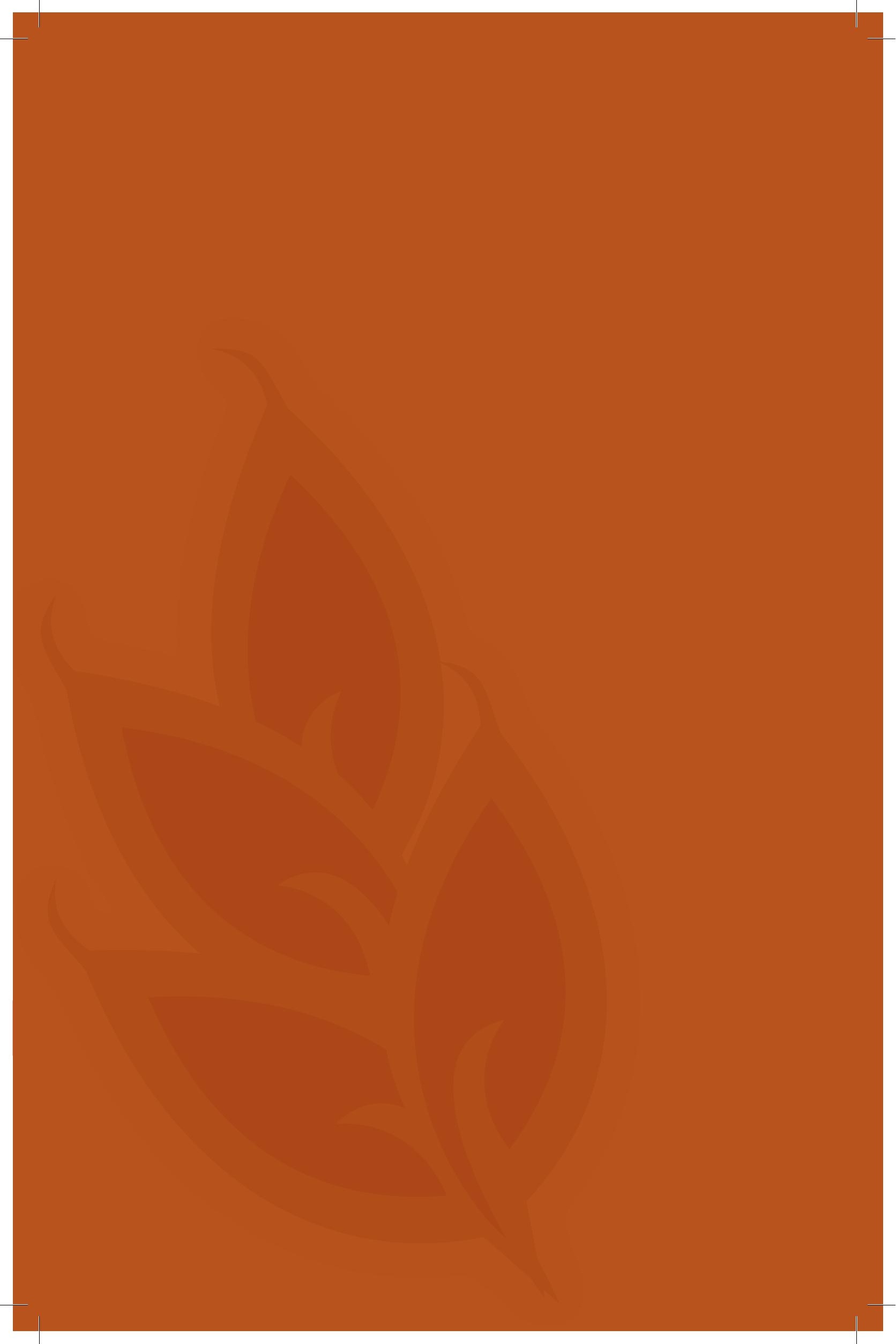




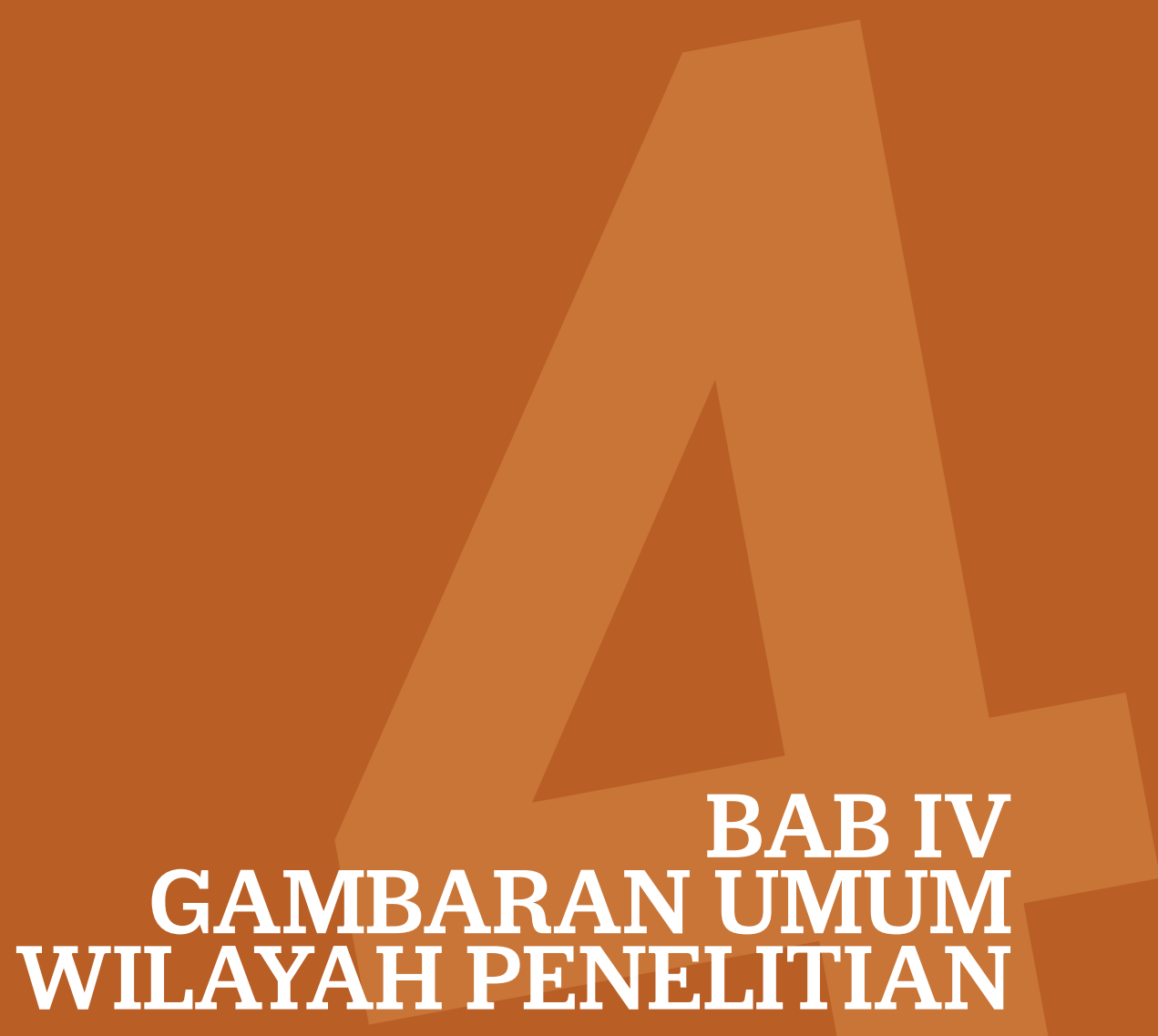




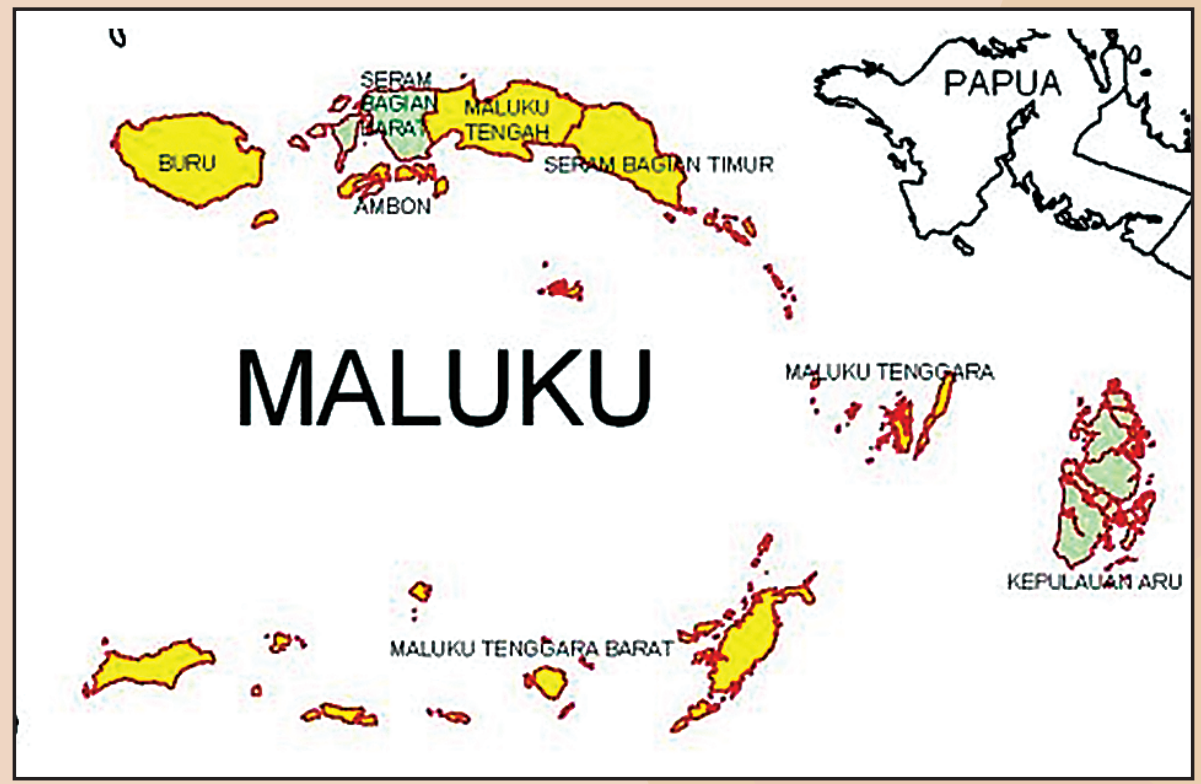

Gambar 4.1. Provinsi Maluku

Maluku merupakan salah satu provinsi di kawasan Timur Negara Republik Indonesia yang memiliki posisi strategis, karena kedudukannya berada antara sebagian wilayah Barat dan Tengah Indonesia dengan Papua di bagian Timur, serta menjadi penghubung wilayah Selatan yakni Negara Australia dan Timor Leste dengan wilayah Utara yaitu Maluku Utara dan Sulawesi. Selain itu, Provinsi Maluku berada pada jalur lintas internasional yaitu dilalui oleh 3 (tiga) Alur Laut Kepulauan Indonesia (ALKI). Posisi ini mempunyai arti yang sangat strategis di bidang ekonomi, perdagangan dan investasi. 


\section{PROVINSI MALUKU}

Secara geografis, Provinsi Maluku berbatasan dengan Provinsi Maluku Utara di bagian Utara, Provinsi Papua Barat di bagian Timur, Negara Timor Leste dan Negara Australia di bagian Selatan, serta Provinsi Sulawesi Tenggara dan Sulawesi Tengah di bagian Barat. Sebagai daerah kepulauan, Provinsi Maluku memiliki luas wilayah $712.480 \mathrm{Km} 2$, terdiri dari sekitar 92,4\% lautan dan 7,6\% daratan dengan jumlah pulau yang mencapai 1.412 buah pulau dan panjang garis pantai 10.662 Km. Sejak tahun 2008, Provinsi Maluku terdiri atas 9 kabupaten dan 2 kota.

\subsection{Karakteristik Wilayah}

Pemerintah Provinsi Maluku telah menetapkan Peraturan Daerah Provinsi Maluku Nomor 14 Tahun 2005 tentang Penetapan Kembali Negeri Sebagai Kesatuan Masyarakat Hukum Adat Dalam Wilayah Pemerintahan Provinsi Maluku. Perda tersebut menyatakan bahwa salah satu syarat agar seseorang bisa mengklaim hak-hak adat adalah memiliki hubungan historis dengan wilayah. Masyarakat yang tidak memenuhi syarat tersebut masuk ke dalam desa administratif.

\section{TABEL 4.1. KABUPATEN DAN KOTA DI PROVINSI MALUKU}

\begin{tabular}{|c|l|l|c|c|c|}
\hline NO. & KABUPATEN/KOTA & IBU KOTA & JLH KEC & JLH DESA & JLH KEL \\
\hline 1 & Kabupaten Buru & Namlea & 5 & 82 & - \\
\hline 2 & Kabupaten Buru Selatan & Namrole & 5 & 55 & - \\
\hline 3 & Kabupaten Kepulauan Aru & Dobo & 7 & 117 & 2 \\
\hline 4 & Kabupaten Maluku Barat Daya & Tiakur & 8 & 117 & - \\
\hline 5 & Kabupaten Maluku Tengah & Masohi & 17 & 162 & 6 \\
\hline 6 & Kabupaten Maluku Tenggara & Langgur & 6 & 86 & 1 \\
\hline 7 & Kabupaten Maluku Tenggara Barat & Saumlaki & 10 & 74 & 1 \\
\hline 8 & Kabupaten Seram Bagian Barat & Piru (de facto) & 11 & 92 & - \\
\hline 9 & Kabupaten Seram Bagian Timur & Bula (de facto) & 12 & 148 & - \\
\hline 10 & Kota Ambon & Ambon & 5 & 30 & 20 \\
\hline 11 & Kota Tual & Tual & 4 & 26 & 3 \\
\hline
\end{tabular}

Sumber : Wikipedia, 2013

Berdasarkan identifikasi citra satelit LAPAN, jumlah keseluruhan pulau-pulau di Provinsi Maluku adalah 1.412 buah pulau. Luas pulaupulau di provinsi ini, bervariasi antara $\leq 761$ km2 sampai 18.625 km2. Pulau dengan luas kurang dari 1 juta ha dikategorikan sebagai pulau kecil, dengan kategori pulau seperti itu, maka hanya pulau Seram yang memiliki luas diatas 186 juta ha dan tidak termasuk pulau kecil sedangkan sisanya sebanyak 1.411 buah pulau termasuk kategori pulau-pulau kecil.
Hal ini mengingat bahwa penyelenggaraan Pemerintahan di Kota Ambon mempunyai karakteristik tersendiri dimana sebagian besar wilayah Kota Ambon terdiri atas Negeri dengan adat-istiadat yang hidup, diakui, dihormati, dipertahankan, dipatuhi dan dilaksanakan oleh masyarakat adat, serta adanya bagian wilayah Negeri-Negeri yang telah dibentuk menjadi Desa dan Kelurahan berdasarkan Peraturan Perundang-undangan yang berlaku. Hal ini merupakan aspirasi masyarakat pada Negeri 
di Kota Ambon menghendaki agar sistem penyelenggaraan pemerintahan dikembalikan menurut adat istiadat dan hukum adat yang berlaku di Kota Ambon.

Oleh karenanya pada tahun 2008 telah diterbitkan Perda Nomor - 3 Tahun 2008 Tentang Negeri Di Kota Ambon.

Dalam Perda ini diatur ketentuan mengenai :

1. Kecamatan adalah daerah kerja Camat sebagai perangkat Pemerintah Kota Ambon;

2. Negeri adalah Kesatuan Masyarakat Hukum Adat yang memiliki batas-batas wilayah, yang berwenang untuk mengatur dan mengurus kepentingan masyarakat setempat berdasarkan asal usul, adat istiadat dan hukum adat setempat, diakui dan dihormati dalam sistem Pemerintahan Negara Kesatuan Republik Indonesia;

3. Peraturan Negeri adalah peraturan perundang-undangan yang dibuat oleh Saniri Negeri Lengkap bersama Raja;

4. Desa adalah kesatuan masyarakat hukum yang memiliki batas-batas wilayah yang berada dalam wilayah petuanan Negeri yang diakui, berwenang untuk mengatur dan mengurus kepentingan masyarakat setempat berdasarkan perundangundangan yang berlaku;

5. Petuanan adalah daerah yang meliputi daratan dan lautan, yang berdasarkan hukum adat Ambon berada di bawah penguasaan Negeri

6. Pemerintahan Negeri adalah Penyelenggaraan urusan Pemerintahan oleh

7. Pemerintah Negeri dan Saniri Negeri Lengkap dalam mengatur dan mengurus kepentingan masyarakat setempat sesuai ketentuan Perundangan-undangan yang berlaku diakui dan dihormati dalam sistem Pemerintahan Negara Kesatuan Republik Indonesia;

8. Pemerintah Negeri adalah Raja,
Saniri Rajapatti, dan Saniri Negeri Lengkap sebagai unsur penyelenggara Pemerintahan Negeri;

9. Saniri Rajapati atau Dewan Negeri adalah penyelenggara Pemerintahan Negeri;

10. Raja adalah Gelar Kepala Pemerintahan Negeri yang merupakan unsur

11. Penyelenggaraan kesatuan masyarakat hukum adat, berfungsi mengurus hukum adat dan adat istiadat serta tugastugas pemerintahan sesuai ketentuan perundang-undangan yang berlaku;

12. Sekretaris Negeri adalah perangkat Saniri Rajapatti yang melaksanakan tugastugas administrasi Pemerintahan Negeri;

13. Kewang adalah polisi hutan sebagai perangkat Saniri Rajapatti yang melaksanakan tugas pengawasan kekayaan sumber daya alam Negeri dalam petuanan Negeri;

14. Saniri Negeri Lengkap adalah Badan legislatif Negeri yang terdiri dari wakilwakil Soa, Kepala Adat, Tua-Tua Negeri, Kepala Tukang, Kewang, serta unsurunsur lain yang bertugas membantu Kepala Pemerintahan Negeri membentuk Peraturan Negeri serta melakukan fungsi pengawasan;

15. Saniri Besar adalah rapat terbuka bersama Saniri Rajapatti dan Saniri Negeri Lengkap dengan seluruh anak Negeri yang sudah dewasa untuk mendengar laporan keterangan mengenai penyelenggaraan pemerintahan, pembangunan dan pelayanan kemasyarakatan serta penyampaian rencana pembangunan Negeri oleh Rajapatti.

16. Soa adalah suatu persekutuan teritorial geneologis yang ada di Negeri, terdiri atas beberapa Matarumah;

17. Soa Parenta adalah Matarumah yang berdasarkan hukum adat dan adat istiadat setempat untuk memimpin penyelenggaraan pemerintahan di Negeri; 
18. Kepala Soa adalah Kepala Persekutuan Territorial Genealogis yang bertugas membantu Raja dalam pelaksanaan Pemerintahan Negeri, mewakili Soa;

19. Marinyo adalah perangkat Saniri Rajapatti yang diserahi tugas menyampaikan berita yang berkaitan dengan tugas-tugas Pemerintahan maupun adat istiadat Negeri;

20. Kampong adalah suatu persekutuan masyarakat yang mendiami wilayah tertentu dalam petuanan Negeri;

21. Kepala Kampong adalah kepala persekutuan masyarakat yang membantu Raja dalam melaksanakan tugas-tugas Pemerintahan pada suatu wilayah tertentu dalam petuanan Negeri;

22. Latupati adalah lembaga musyawarah para Raja untuk membicarakan kepentingan bersama antar Negeri;

23. Kewenangan Negeri adalah Hak dan kekuasaan Pemerintah Negeri untuk mengambil kebijakan dalam penyelenggaraan Pemerintahan Negeri.

Negeri sebagai kesatuan masyarakat hukum adat selain memiliki ciri-ciri petuanan dengan batas-batasnya, juga dicirikan antara lain dengan adanya :

1. nama Teon Negeri;

2. baileo;

3. batu Pamali;

4. matarumah asal/asli;

5. soa;

6. upacara Adat Negeri;

7. unsur adat istiadat yang diakui masyarakat adat setempat yang selanjutnya diatur oleh Peraturan Negeri.

Urusan Pemerintahan yang menjadi kewenangan Negeri mencakup:

1. kewenangan atas petuanan Negeri;

2. urusan pemerintahan yang sudah ada berdasarkan hak asal usul dan hukum adat Negeri;
3. urusan pemerintahan yang menjadi kewenangan daerah yang diserahkan pengaturannya kepada Negeri;

4. tugas Pembantuan dari Pemerintah, Pemerintah Provinsi, dan Pemerintah Kota;

5. urusan pemerintahan lainnya yang oleh Peraturan Perundang-Undangan diserahkan pengaturannya kepada Negeri.

Struktur Pemerintahan Negeri terdiri atas :

1. saniri Rajapatti;

2. saniri Negeri Lengkap.

Saniri Rajapatti terdiri atas :

1. raja;

2. para Kepala Soa;

3. perangkat Negeri.

Saniri Negeri Lengkap terdiri atas :

1. raja sebagai Ketua;

2. wakil dari Soa sebagai anggota;

3. kepala adat sebagai anggota;

4. tua-tua Negeri sebagai anggota;

5. kepala Tukang sebagai anggota;

6. kewang sebagai anggota.

Soa terdiri atas satu atau beberapa Matarumah yang terdapat di Negeri.

Soa dipimpin oleh seorang Kepala Soa.

Raja diutamakan berasal dari anak Negeri atau anak adat dari Matarumah dalam Soa Parenta. Apabila ketentuan dimaksud tidak dapat dipenuhi maka dapat diusulkan anak Negeri dari Soa lain. Pengusulan sebagaimana di maksud dilakukan dalam musyawarah Soa Parenta.

Persetujuan Soa Parenta diwujudkan dalam bentuk mandat tertulis yang ditandatangani oleh Kepala Soa Parenta.

Masa jabatan Raja adalah 6 (enam) tahun dan dapat dipilih kembali. Pengisian jabatan Raja dapat dilakukan melalui pemilihan dan/atau pengangkatan. Tata cara pemilihan dan/atau 
pengangkatan, pelantikan, dan pemberhentian Raja diatur dengan Peraturan Daerah.

Pembentukan keluarga di daerah Maluku berdasarkan pengelompokan baik karena faktor genealogis, maupun teritorial atau gabungan dari keduanya. Yang tertua adalah keturunan atau hubungan darah(genealogis), dan ini dapat dibagi lagi kepada matrilineal (garis ibu) dan pattrillineal (bapak). Susunan masyarakat mulai dari keluarga sebagai unit terkecil. Urutan selanjutnya adalah rumatau, uku atau soa, aman atau negeri.

\section{Rumatau}

Kesatuan kelompok genealogis yang lebih besar sesudah keluarga adalah rumatau atau lumatau. Kata pokoknya adalah "ruma" atau "rumah". Sebutan untuk kata ruma ini berbeda di beberapa tempat, sesuai dengan dialek setempat. Menurut dialek Saparua disebut lumal, dialek Nusalaut rumal, dialek Haruku ruma, dialek Hila dan Asilulu luma. Kalau tau bias diartikan "isi", maka rumatau berarti rumah yang didiami bersama-sama oleh orangorang yang seketurunan dan keanggotaannya tersusun menurut garis bapak. Nama lain yang popular di kalangan rakyat untuk rumatau ini adalahmata-mata.Mata berarti "asal" atau induk., jadi mataruma berarti rumah induk atau rumah asal. Sebuah rumatau biasanya terdiri atas beberapa keluarga dengan kepala keluarganya masing-masing. Dari rumataurumatau inilah berkembangnya susunan masyarakat. Untuk mengatur urusan suatu rumatau, baik dalam hubungan ke dalam rumatau, maupun terhadap pihak ke luar, maka diangkatlah salah seorang drai anggota rumatau yang bersangkutan menjadi pimpinan dengan gelar "Upu".

\section{Uku}

Karena pertambahan isi rumatau dengan lahirnya manusia-manusia baru di dalam rumatau tersebut, maka lama kelamaan rumah besar yang didiami bersama itu ruangannya tidak mencukupi lagi. Ruangan-ruangan seperti menjadi sempit. Dengan semakin padatnya isi rumah, maka timbullah berbagai masalah intern anggota-anggota rumatau itu. Karena itu timbullah keinginan dari sementara penghunipenghuni untuk keluar memisahkan diri dari rumah besar itu dan membangun tempat tinggal sendiri di luar rumah bersama itu dan tentu saja setlah mendapat persetujuan dari upunya. Pada perkembangan yang pertama segala urusan diatur oleh upu dari rumatau tua, tetapi lama kelamaan dengan bertambahnya keturunan dari rumatau yang memencar dan semakin banyak pula rumah tangga baru serta banyaknya masalah yang timbul sehingga "upu" dari rumatau tua tidak mampu lagi mengurus semuanya itu secara terpusat. Oleh karena itu, timbullah pemikiran agar rumahtangga-rumah tangga yang memencar itu, sendiri-sendiri atau bergabung beberapa rumah tangga membentuk rumatau baru yang terlepas dari rumatau tua. Walaupun terjadi pemisahan diri, namun rumatau tua tetap dianggap sebagai induknya dan rumataurumatau yang baru adalah cabangnya. Dengan demikian, rumatau-rumatau yang sudah banyak itu menempati wilayah yang lebih luas yang disebut uku atau huku dengan seorang pemimpin bergelar Tamaela.

\section{Soa}

Soa adalah suatu persekutuan territorial genealogis. Di dalam wilayah administrasi pemerintah,sekarang ini soa merupakan suatu wilayah yang menjadi bagian dari 
suatu petuanan atau negeri. Dibawah soa ini bernaung beberapa rumatau. Di dalam kenyataannya rumatau-rumatau dalam soa-soa tersebut tidak seketurunan. Mereka berasal dari keturunan yang berbeda-beda yang secara kebetulan menempati wilayah yang sama. Seringkali soa disamakan dengan uku oleh masyarakat. Akan tetapi pada kenyataannya ke-2 persekutuan ini berbeda. Jika pada uku unsure genealogislah yang paling dominan, maka pada soa unsure teritoriallah yang paling dominan dan yang menyebabkan rumataurumatau bergabung bersama. Soa biasanya dipimpin oleh seorang "Kepala Soa".

\section{Hena dan Aman}

Hena adalah suatu kesatuan masyarakat yang berunsurkan territorial. Di Ambon Lease hena aslinya adalah sebuah persekutuan yang lebih besar dari uku. Sebuah hena bisa terdiri dari beberapa uku.

Aman adalah suatu kesatuan dari pembagianpembagian yang bersifat territorial serta memiliki kedudukan yang sama dengan hena. Hena atau Aman ini adalah bentuk kuno dari kesatuan atau persekutuan yang bersifat territorial dan sekarang tidak terpakai lagi.

\section{Struktur masyarakat kabupaten Maluku Tenggara}

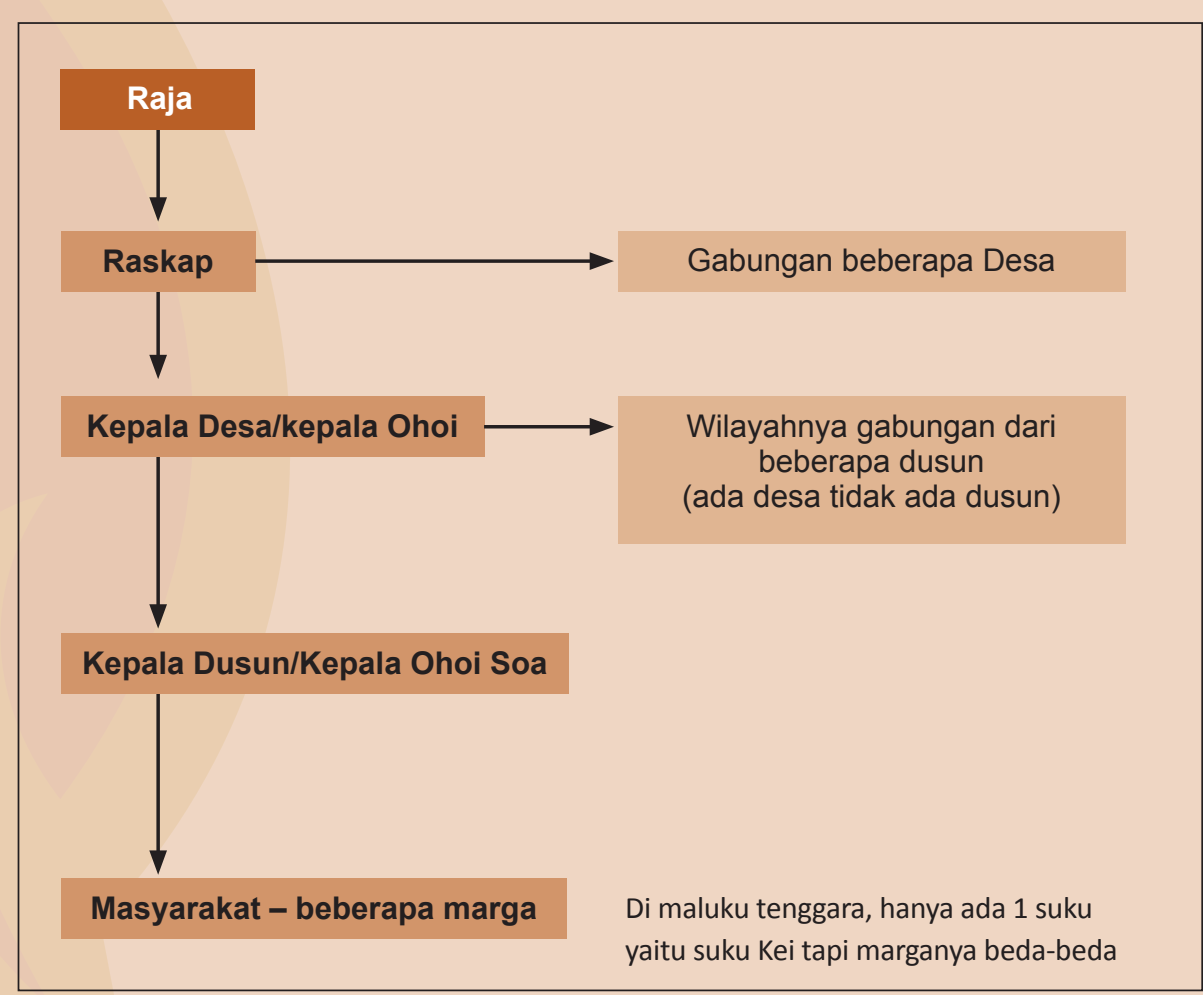




\begin{abstract}
Negeri
Istilah Negeri bukanlah berasal dari bahasa asli daerah ini atau "bahasa tanah". Suatu negeri adalah persekutuan territorial yang terdiri atas beberapa soa yang pada umumnya berjumlah paling sedikit tiga buah. Sebuah negeri dipimpin oleh seorang kepala Negeri yang disebut Pamerentah dan sehari-hari dipanggil "raja".
\end{abstract}

\section{Uli}

Uli adalah suatu persekutuan yang terbentuk atau tersusun atas beberapa hene atau aman. Uli adalah lembaga masyarakat yang khusus terdapat di daerah Ambon Lease.

\subsection{Pemilikan/Penguasaan Tanah}

Tanah-tanah di Kota Ambon terdiri dari tanah eigendom verponding yang tercatat dalam register 1814 dan tanah adat atau dikenal sebagai tanah dati. Register dati ( mirip letter C) berupa peta yang dibuat oleh Belanda tahun 1814 dengan menggunakan batas alam dan tertera nama-nama dati seperti dati Tomalahu. Tanah adat tunduk kepada dan juga dikuasai oleh hak petuanan (beschikkingsrecht) dari desa atau negeri yang bersangkutan. Namun pada umumnya tanah-tanah di daerah Ambon Lease adalah tanah adat yang tunduk kepada dan juga dikuasai oleh hak petuanan dari desa atau negeri yangbersangkutan. Tanah-tanah adat ini dapat disebut juga tanah ulayat dan digolongkan kepada tanah negara yang tidak bias bebas.

Hak petuanan dari suatu negeri bagian daratan tidak hanya mengenai tanahnya saja, tetapi juga meliputi hutan, sungai dan segala hasilnya. Karena daerah Ambon Lease suatu daerah kepulauan, maka wilayah petuanan juga meliputi perairan sepanjang pantai yang di depannya sampaikebatas air putih di mana kita masih bias melihat dasar lautnya. Dalam perkembangan kemudian sebagian dari tanah petuanan itu lepas dari kekuasaan dan pengaturan langsung dari hak petuanan negerinegeri yang bersangkutan, karena pada tanahtanah tersebut telah muncul hak-hak yang bersifat perorangan atau hak-hak lainnya yang lebih kuat dari hak petuanan itu. Penguasaan atas tanah-tanah adat itu oleh hak petuanan bukanlah sekedar untuk dikuasai saja, tetapi juga supaya pemanfaatannya berjalan dengan tertib, karena tanah, hutan, laut dan segala isinya adalah semacam lumbung dan sumber nafkah utama bagi rakyat

Terdapat tiga macam golongan tanah di Kota Ambon :

1. Tanah negeri atau tanah hak petuanan, yang di miliki atau dikuasai oleh persekutuan atau negeri ;

2. Tanah dati parusah, tanah yang dimiliki oleh perorangan, akibat pemberian oleh negeri dan dikelolah secara turun temurun oleh setiap kelompok marga.

3. Tanah dati pusaka, yang merupakan kelanjutan dari tanah dati parusah, dimana tanah negeri yang awalnya diberikan kepada seseorang untuk berusaha atau yang dikenal dengan dati parusah, kemudian dalam perkembanganya diwariskan kepada ahli warisnya untuk dipergunakan atau dan/atau di kelolah serta dimanfaatkan bersama-sama secara turun temurun, sehingga telah menjadi milik banyak orang (para warisnya).

\subsection{Profil Kasus Pertanahan}

Menurut informasi dari responden Kota Ambon, tipologi masalah penguasaan dan pemilikan tanah dan masalah batas/letak bidang tanah merupakan masalah yang paling dominan ditemukan di kota Ambon. Selain 
itu juga ditemukan sengketa mengenai batas wilayah adat, tanah adat ini bukti nya sangat lemah kadang hanya berdasarkan cerita.

Adapun untuk Kabupaten maluku tenggara, banyak dijumpai kasus tanah marga (tanah adat), terhadap kasus yang ada telah diusahakan untuk dilakukan mediasi namun sulit untuk mempertemukan para pihak. Mediasi di daerah ini dilakukan maksimal 2 kali, jika sulit didamaikan maka dikembalikan ke desa untuk diselesaikan melalui lembaga adat desa dimana kepala desa bertindak sebagai ketua persekutuan hukum adat. Frekwensi konflik bertambah ketika terjadi pemekaran, tanah yang tadinya tidak ada harganya menjadi mempunyai nilai ekonomis.
Kasus pertanahan yang sifatnya perorangan lebih mudah dimediasi dibandingkan kasus tanah yang melibatkan marga.

Proses mediasi dilakukan dengan tahapan :

1. Memanggil pihak A tanpa B.

2. Memanggil pihak $B$ tanpa $A$.

3. Setelah itu kedua belah pihak dipertemukan.

4. Jika tidak terselesaikan di sarankan untuk ke Pengadilan atau sidang adat.

Kabupaten Maluku Tenggara terdiri atas 6 kecamatan, yaitu Kei Kecil, Kei Kecil Barat, Kei Kecil Timur, Kei Besar, Kei Besar Utara Timur, Kei Besar Selatan. Ibukota kabupaten ini terletak di Tual, setelah Kota Tual resmi menjadi daerah otonom, maka ibukota kabupaten ini dipindahkan ke Langgur.

\section{TABEL. 4.2. TIPOLOGI MASALAH PROVINSI MALUKU}

\begin{tabular}{|c|c|c|c|c|c|}
\hline NO. & TIPOLOGI & KANWIL & $\begin{array}{c}\text { KOTA } \\
\text { AMBON }\end{array}$ & $\begin{array}{c}\text { KAB. MALUKU } \\
\text { TENGGARA }\end{array}$ & $\begin{array}{c}\text { KAB. MALUKU } \\
\text { TENGAH }\end{array}$ \\
\hline 1. & $\begin{array}{l}\text { Masalah Penguasaan dan } \\
\text { Pemilikan Tanah }\end{array}$ & $90 \%$ & $40 \%$ & $75 \%$ & $10 \%$ \\
\hline 2. & Masalah batas/letak bidang tanah & $80 \%$ & $30 \%$ & $10 \%$ & $4 \%$ \\
\hline 3. & $\begin{array}{l}\text { Masalah prosedur Penetapan } \\
\text { Hak \& Pendaftaran Tanah }\end{array}$ & $40 \%$ & $5 \%$ & - & - \\
\hline 4. & $\begin{array}{l}\text { Masalah pelaksanaan } \\
\text { putusan pengadilan }\end{array}$ & - & $5 \%$ & $5 \%$ & - \\
\hline 5. & Masalah tanah ulayat & $10 \%$ & $10 \%$ & $10 \%$ & $1 \%$ \\
\hline 6. & Masalah tanah obyek Landreform & $5 \%$ & $8 \%$ & - & - \\
\hline 7. & $\begin{array}{l}\text { Masalah ganti rugi tanah } \\
\text { ex. Partikelir }\end{array}$ & $5 \%$ & - & - & - \\
\hline 8. & Masalah pengadaan tanah & $10 \%$ & $2 \%$ & - & - \\
\hline
\end{tabular}

Sumber: Hasil Pengumpulan Data di Lapangan, 2013 
Di daerah ini juga dikenal "sasi", yaitu tindakan penyegelan, seperti yang terjadi pada pembangunan bandara Tual dimana jalan menuju bandara di sasi oleh masyarakat adat dari marga renyaan, renmeua, dan materbong di Desa Kolser, Maluku Tenggara, Maluku, dengan membawa berbagai senjata tajam memasang sasi adat di atas tanah adat seluas 25 hektar. Aksi ini sebagai bentuk protes atas penjualan tanah tersebut oleh sejumlah warga dari marga materbong ke Pemerintah Kabupaten Maluku Tenggara. Warga memasang sasi adat dengan cara menanam daun janur sebagai simbol larangan adat

\section{TABEL. 4.3. TIPOLOGI KASUS PERTANAHAN HASIL RDP}

\begin{tabular}{|c|c|c|c|c|c|}
\hline NO. & TIPOLOGI & KANWIL & $\begin{array}{l}\text { KOTA } \\
\text { AMBON }\end{array}$ & $\begin{array}{c}\text { KAB. MALUKU } \\
\text { TENGGARA }\end{array}$ & $\begin{array}{c}\text { KAB. MALUKU } \\
\text { TENGAH }\end{array}$ \\
\hline 1. & Masyarakat dengan swasta & 4 & - & - & 1 \\
\hline 2. & TNI dengan POLRI & 5 & $\begin{array}{c}3 \\
\text { (lanud } \\
\text { vs masy) }\end{array}$ & - & - \\
\hline 3. & Masyarakat Adat & - & 10 & $\begin{array}{c}49 \\
(99 \%)\end{array}$ & 1 \\
\hline 4. & Kehutanan & 2 & - & - & - \\
\hline 5. & ESDM/Pertambangan & - & - & - & - \\
\hline 6. & BUMN & 4 & - & - & - \\
\hline 7. & PU/Departemen lainnya & - & - & - & - \\
\hline
\end{tabular}

Sumber: Hasil Pengumpulan Data di Lapangan, 2013

TABEL. 4.4. FREKWENSI KASUS PERTANAHAN DAN PENYELESAIANNYA

\begin{tabular}{|c|l|c|c|c|c|c|}
\hline NO & WILAYAH PENELITIAN & SENGKETA & KONFLIK & MEDIASI & LITIGASI & $\begin{array}{c}\text { EXECUTOIR } \\
\text { BESLAAG }\end{array}$ \\
\hline 1. & Kanwil & 69 & 6 & 69 & & - \\
\hline 2. & Kantah Kota & & - & $40 \%$ & $50 \%$ & - \\
\hline 3. & Kantah Kab Mal-teng & 30 & 20 & 20 & - & - \\
\hline 4. & Kantah kab. Mal.Tengah & 12 & 1 & 2 & 4 & - \\
\hline
\end{tabular}

Sumber: Hasil Pengumpulan Data di Lapangan, 2013 


\section{TABEL. 4.5. ASPEK YANG DITELITI DALAM PENELITIAN MENGENAI AKAR MASALAH}

\begin{tabular}{|l|l|l|}
\hline NO & WILAYAH PENELITIAN & ASPEK YANG DITELITI SELAIN ASPEK YURIDIS \\
\hline 1. & Kanwil & Aspek sosiologi kurang diteliti \\
\hline 2. & Kantah Kota & $\begin{array}{l}\text { Disamping aspek yuridis, maka aspek sosiologi dan aspek } \\
\text { lainnya ikut mempengaruhi terjadinya sengketa tanah di ambon, } \\
\text { misalnya kasus sengketa tanah di kawasan gunung malintang } \\
\text { desa hative kecil, kec. Sirimau, ambon. }\end{array}$ \\
\hline 3. & Kantah Kab Mal-teng & Ya, aspek sosiologi dan antropologi menjadi pertimbangan \\
\hline 4. & Kantah kab. Mal.Tengah & sda \\
\hline
\end{tabular}

Sumber: Hasil Pengumpulan Data di Lapangan, 2013

TABEL. 4.6. TIM KHUSUS PENYELESAIAN KASUS PERTANAHAN

\begin{tabular}{|l|l|l|}
\hline NO & WILAYAH PENELITIAN & $\begin{array}{r}\text { APAKAH ADA TIM KHUSUS PENYELESAIAN KASUS } \\
\text { PERTANAHAN DI TINGKAT PROVINSI, DAN KABUPATEN/KOTA }\end{array}$ \\
\hline 1. & Kanwil & Ada tim khusus tingkat Provinsi \\
\hline 2. & Kantah Kota & Tidak ada di tingkat kota \\
\hline 3. & Kantah Kab Mal-teng & Tidak ada di tingkat kab malteng \\
\hline 4. & Kantah kab. Mal. Tengah & Tidak ada di tingkat kabupaten \\
\hline
\end{tabular}

Sumber: Hasil Pengumpulan Data di Lapangan, 2013

untuk melakukan aktivitas di lahan tersebut. Mereka berharap penjual tanah adat tersebut segera mengembalikan uang hasil penjualan sebesar Rp 5,5 miliar kepada Pemkab Maluku Tenggara. Warga juga minta pemda setempat kembali melakukan negosiasi pembelian melalui tiga marga tersebut.

Dari tabel di depan menunjukkan masalah penguasaan dan pemilikan tanah merupakan masalah yang tertinggi di Provinsi Maluku, yang kedua adalah masalah batas/letak bidang tanah, dan ketiga adalah masalah prosedur penetapan hak dan pendaftaran tanah, keempat adalah nasalah tanah ulayat dan masalah pengadaan tanah, kelima adalah masalah tanah obyek landreform dan masalah ganti rugi tanah ex partikulir, sedangkan masalah pelaksanaan putusan pengadilan tidak ditemukan di Kantor Wilayah, hanya ada di Kota Ambon dan kab. Maluku Tenggara.

Tipologi kasus pertanahan ( RDP) sebagaimana dalam table 4.3 menunjukkan kasus pertanahan antara TNI dengan POLRI tertinggi di Kantor Wilayah, kedua kasus pertanahan antara masyarakat dengan swasta dan BUMN, yang ketiga, kasus pertanahan terkait kehutanan. Sedangkan kasus pertanahan di Kota Ambon yang ada mengenai konflik antara Lanud dengan masyarakat, untuk Kab. Maluku Tenggara, kasus yang ada mengenai masyarakat adat, dan untuk kab. Maluku tengah, kasus yang ada mengenai masyarakat adat dan masyarakat dengan swasta. 
Frekwensi kasus pertanahan menunjukkan sengketa lebih banyak dibandingkan konflik, hal ini ditemukan baik di kantor Wilayah, maupun Kab. Maluku Tengah dan Kab. Maluku Tenggara. Sedangkan untuk konflik, frekwensi konflik paling tinggi di Kab. Maluku tengah, kedua ditemukan di kantor Wilayah, dan paling sedikit di kab. Maluku tengah. Upaya penyelesaian melalui litigasi lebih banyak ditempuh dibandingkan upaya penyelesaian dengan mediasi.

Dalam penelitian akar masalah yang dihadapi, maka aspek yang diteliti pada umumnya hanya mengenai aspek fisik dan yuridis, sedangkan aspek sosiologi dan aspek antropologi kurang mendapat perhatian.
Mengenai tim khusus penyelesaian sengketa pertanahan hanya dibentuk untuk tingkat Provinsi.

Eksekusi berita acara tim penyelesaian kasus pertanahan menurut informasi responden belum bisa dilaksanakan baik di tingkat Provinsi maupun di tingkat kabupaten.

Tabel 4.8 di atas menunjukkan bahwa peta/ data sebaran sengketa/konflik hanya ada di Kota Ambon, itupun belum menyeluruh disetiap kelurahan hanya kelurahan tertentu saja yang ada peta masalah dan karakteristik yang menonjol adalah sengketa batas.

\section{TABEL. 4.7. EKSEKUSI BERITA ACARA TIM PENYELESAIAN KASUS}

\begin{tabular}{|l|l|l|}
\hline NO & WILAYAH PENELITIAN & \multicolumn{1}{|c|}{ EKSEKUSI SESUAI DENGAN BERITAACARA HASIL TIM } \\
PENYELESAIAN KASUS
\end{tabular}

Sumber: Hasil Pengumpulan Data di Lapangan, 2013

\section{TABEL. 4.8. PETA/DATA SEBARAN SENGKETA/KONFLIK}

\begin{tabular}{|c|l|l|}
\hline NO & WILAYAH PENELITIAN & \multicolumn{1}{|c|}{ PETA/DATA SEBARAN SENGKETA/KONFLIK } \\
\hline 1. & Kanwil & Tidak ada \\
\hline 2. & Kantah Kota & $\begin{array}{l}\text { Ada, tetapi belum menyeluruh di setiap kelurahan, hanya } \\
\text { kelurahan tertentu saja yang ada peta masalah dan karakteristik } \\
\text { yang menonjol adalah sengketa batas }\end{array}$ \\
\hline 3. & Kantah Kab Mal-teng & Tidak ada \\
\hline 4. & Kantah kab. Mal.Tengah & Belum ada \\
\hline
\end{tabular}

Sumber: Hasil Pengumpulan Data di Lapangan, 2013 


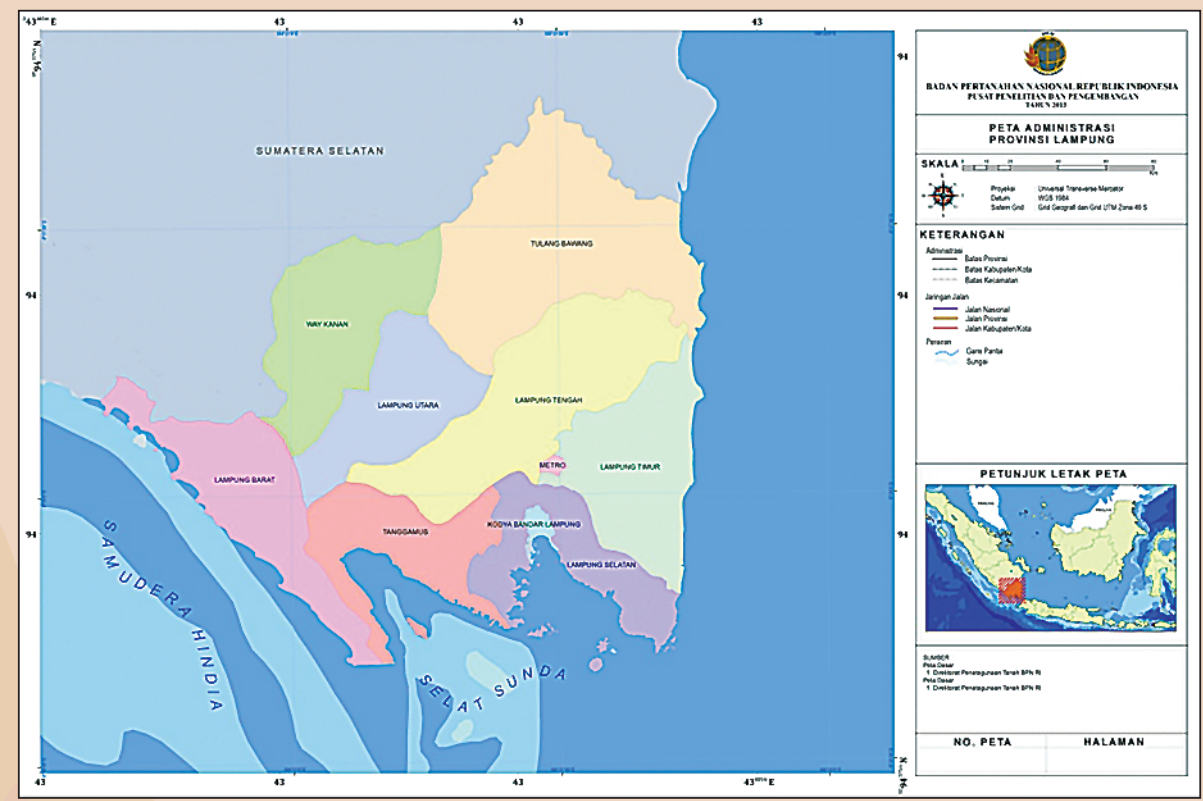

Gambar 4.2. Peta Administrasi Provinsi Lampung

\section{PROVINSI LAMPUNG}

\subsection{Karakteristik Wilayah}

Provinsi Lampung memiliki luas 35.376,50 $\mathrm{km}^{2}$ dan terletak di antara $105^{\circ} 45^{\prime}-103^{\circ} 48^{\prime}$ BT dan $3^{\circ} 45^{\prime}-6^{\circ} 45^{\prime}$ LS. Daerah ini di sebelah barat berbatasan dengan Selat Sunda dan di sebelah timur dengan Laut Jawa. Beberapa pulau termasuk dalam wilayah Provinsi Lampung, yang sebagian besar terletak di Teluk Lampung, di antaranya: Pulau Darot, Pulau Legundi, Pulau Tegal, Pulau Sebuku, Pulau Ketagian, Pulau Sebesi, Pulau Poahawang, Pulau Krakatau, Pulau Putus dan Pulau Tabuan. Ada juga Pulau Tampang dan Pulau Pisang di yang masuk ke wilayah Kabupaten Lampung Barat.

Keadaan alam Lampung, di sebelah barat dan selatan, di sepanjang pantai merupakan daerah yang berbukit-bukit sebagai sambungan dari jalur Bukit Barisan di Pulau Sumatera. Di tengah-tengah merupakan dataran rendah. Sedangkan ke dekat pantai di sebelah timur, di sepanjang tepi Laut Jawa terus ke utara, merupakan perairan yang luas.

\subsection{Struktur Pemerintahan dan Masyarakat}

Masyarakat Lampung dalam bentuknya yang asli memiliki struktur hukum adat tersendiri. Bentuk masyarakat hukum adat tersebut berbeda antara kelompok masyarakat yang satu dengan yang lainnya, kelompokkelompok tersebut menyebar di berbagai tempat di daerah di Lampung. Secara umum dapat dibedakan dalam dua kelompok besar yaitu:

1. masyarakat adat Peminggir yang berkediaman di sepanjang pesisir 
TABEL. 4.9. KABUPATEN/KOTA DI PROVINSI LAMPUNG

\begin{tabular}{|r|l|l|}
\hline NO. & KABUPATEN/KOTA & IBU KOTA \\
\hline 1 & Kabupaten Lampung Barat & Liwa \\
\hline 2 & Kabupaten Lampung Selatan & Kalianda \\
\hline 3 & Kabupaten Lampung Tengah & Gunung Sugih \\
\hline 4 & Kabupaten Lampung Timur & Sukadana \\
\hline 5 & Kabupaten Lampung Utara & Kotabumi \\
\hline 6 & Kabupaten Mesuji & Wiralaga Mulya \\
\hline 7 & Kabupaten Pesawaran & Gedong Tataan \\
\hline 8 & Kabupaten Pringsewu & Pringsewu \\
\hline 9 & Kabupaten Tanggamus & Kota Agung \\
\hline 10 & Kabupaten Tulang Bawang & Menggala \\
\hline 11 & Kabupaten Tulang Bawang Barat & Panaragan Jaya \\
\hline 12 & Kabupaten Way Kanan & Blambangan Umpu \\
\hline 13 & Kabupaten Pesisir Barat & Krui \\
\hline 14 & Kota Bandar Lampung & - \\
\hline 15 & Kota Metro & - \\
\hline Sumber: & Wikipdia, 2013 & \\
\hline
\end{tabular}

termasuk adat Krui, Ranau Komering, sampai Kayu Agung, dan

2. masyarakat adat Pepadun yang berkediaman di daerah pedalaman Lampung terdiri dari masyarakat adat Abung (Abung Siwo Migo), Pubian (Pubian Telu Suku), Menggala / Tulang Bawang (Migo Pak) dan Buai Lima.

Sistem pemerintahan suku lampung bersifat Geneologis Patrilineal Chat artinya kekuasaan diatur berdasarkan garis keturunan patrilineal yaitu anak laki-laki tertua (punyimbang). Apakah sebagai punyimbang marga, punyimbang tijuh atau punyimbang suku.

Pada tahun 1928 Pemerintah Hindia Belanda mengatur kembali struktur Persekutuan hukum adat yang berbentuk marga, melalui Marga Regering Voor de Lampung Districten, sehingga di lampung terdapat 83 marga. sebanyak 78 marga dari 83 marga yang disebutkan diatas merupakan marga mayoritas berpenduduk asli lampung dengan penentuan batas-batas daerah masingmasing.

Setiap marga dipimpin oleh seorang kepala marga atas dasar pemilihan oleh dan dari punyimbang-punyimbang yang bersangkutan. Demikian pula, kepala-kepala kampung ditetapkan berdasarkan hasil pemilihan oleh dan dari para punyimbang. Di seluruh keresidenan Lampung, terdapat marga-marga teritorial sebagai berikut: 
TABEL 4.10. PEMBAGIAN MARGA DI PROVINSI LAMPUNG

\begin{tabular}{|c|c|c|c|c|}
\hline NO. & $\begin{array}{l}\text { NAMA } \\
\text { MARGA }\end{array}$ & $\begin{array}{l}\text { KECAMATAN } \\
\text { SEKARANG }\end{array}$ & BERADAT & $\begin{array}{l}\text { BERBAHASA } \\
\text { (DIALEK) }\end{array}$ \\
\hline 1. & Melinting & Labuhan Maringgai & Peminggir Melinting & A (api) \\
\hline 2. & Jabung & Jabung & idem & idem \\
\hline 3. & Sekampung & idem & idem & idem \\
\hline 4. & Ratu & Dataran Ratu & Peminggir Darah Putih & idem \\
\hline 5. & Dataran & idem & idem & idem \\
\hline 6. & Pesisir & Kalianda & idem & idem \\
\hline 7. & Rajabasa & idem & idem & idem \\
\hline 8. & Ketibung & Way Ketibung & idem & idem \\
\hline 9. & Telukbetung & Telukbetung & Peminggir Teluk & idem \\
\hline 10. & Sabu Mananga & Padangcermin & idem & idem \\
\hline 11. & Ratai & idem & idem & idem \\
\hline 12. & Punduh & idem & idem & idem \\
\hline 13. & Pedada & idem & idem & idem \\
\hline 14. & Badak & Cukuhbalak & Peminggir Pemanggilan (Semaka) & idem \\
\hline 15. & Putih Doh & idem & idem & idem \\
\hline 16. & Limau Doh & idem & idem & idem \\
\hline 17. & Kelumbayan & idem & idem & idem \\
\hline 18. & Pertiwi & idem & idem & idem \\
\hline 19. & Limau & Talangpadang & idem & idem \\
\hline 20. & Gunungalip & idem & idem & idem \\
\hline 21. & Putih & Kedondong & idem & idem \\
\hline 22. & Beluguh & Kotaagung & idem & idem \\
\hline 23. & Benawang & idem & idem & idem \\
\hline 24. & Pematang Sawah & idem & idem & idem \\
\hline 25. & Ngarip Semuong & Wonosobo & idem & idem \\
\hline 26. & Buay Nunyai (Abung) & Kotabumi & Pepadun & $\mathrm{O}$ (nyou) \\
\hline 27. & Buay Unyi & Gunungsugih & idem & idem \\
\hline 28. & Buay Subing & Terbanggi & idem & idem \\
\hline 29. & Buay Nuban & Sukadana & idem & idem \\
\hline 30. & Buay Beliyuk & Terbanggi & idem & idem \\
\hline
\end{tabular}




\begin{tabular}{|c|c|c|c|c|}
\hline NO. & $\begin{array}{l}\text { NAMA } \\
\text { MARGA }\end{array}$ & $\begin{array}{l}\text { KECAMATAN } \\
\text { SEKARANG }\end{array}$ & BERADAT & $\begin{array}{l}\text { BERBAHASA } \\
\text { (DIALEK) }\end{array}$ \\
\hline 31. & BuayNyerupa & Gunungsugih & idem & idem \\
\hline 32. & Selagai & Abung Barat & idem & idem \\
\hline 33. & Anak Tuha & Padangratu & idem & idem \\
\hline 34. & Sukadana & Sukadana & idem & idem \\
\hline 35. & Subing Labuan & Labuan Maringgai & idem & idem \\
\hline 36. & Unyi Way Seputih & Seputihbanyak & idem & idem \\
\hline 37. & Gedongwani & Sukadana & idem & idem \\
\hline 38. & Buay Bolan Udik & Karta (Tulangbawang Udik) & Pepadun (Megou-pak) & idem \\
\hline 39. & Buay Bolan & Menggala & idem & idem \\
\hline 40. & Buay Tegamoan & Tulangbawang Tengah & idem & idem \\
\hline 41. & Buay Aji & Tulangbawang Tengah & idem & idem \\
\hline 42. & Buay Umpu & Tulangbawang Tengah & idem & idem \\
\hline 43. & Buay Pemuka Bangsa Raja & Negeri Besar & Pepadun & A (api) \\
\hline 44. & Buay Pemuka Pangeran llir & Pakuonratu & idem & idem \\
\hline 45. & Buay Pemuka Pangeran Udik & Pakuonratu & idem & idem \\
\hline 46. & Buay Pemuka Pangeran Tuha & Belambangan Umpu & idem & idem \\
\hline 47. & Buay Bahuga & Bahuga (Bumiagung) & idem & idem \\
\hline 48. & Buay Semenguk & Belambangan Umpu & idem & idem \\
\hline 49. & Buay Baradatu & Baradatu & idem & idem \\
\hline 50. & Bungamayang & Negararatu & Pepadun (Sungkai) & idem \\
\hline 51. & Balau & Kedaton & idem & idem \\
\hline 52. & Merak-Batin & Natar & idem & idem \\
\hline 53. & Pugung & Pagelaran & idem & idem \\
\hline 54. & Pubian (Nuat) & Padangratu & idem & idem \\
\hline 55. & Tegineneng & Tegineneng & idem & idem \\
\hline 56. & Way Semah & Gedongtataan & idem & idem \\
\hline 57. & Rebang Pugung & Talangpadang & Semende & Sumatera Selatan \\
\hline 58. & Rebang Kasui & Kasui & idem & idem \\
\hline 59. & Rebang Seputih & Tanjungraya & idem & idem \\
\hline 60. & Way Tube & Bahuga & Ogan & idem \\
\hline
\end{tabular}




\begin{tabular}{|c|c|c|c|c|}
\hline NO. & $\begin{array}{l}\text { NAMA } \\
\text { MARGA }\end{array}$ & $\begin{array}{l}\text { KECAMATAN } \\
\text { SEKARANG }\end{array}$ & BERADAT & $\begin{array}{l}\text { BERBAHASA } \\
\text { (DIALEK) }\end{array}$ \\
\hline 61. & Mesuji & Wiralaga & Pegagan & idem \\
\hline 62. & Buay Belunguh & Belalau & Peminggir (Belalau) & A (api) \\
\hline 63. & Buay Kenyangan & Batubrak & idem & idem \\
\hline 64. & Kembahang & Batubrak & idem & idem \\
\hline 65. & Sukau & Sukau & idem & idem \\
\hline 66. & Liwa & Balik Bukit Liwa & idem & idem \\
\hline 67. & Suoh & Suoh & idem & idem \\
\hline 68. & Way Sindi & Karya Penggawa & idem & idem \\
\hline 69. & La'ai & Karya Penggawa & idem & idem \\
\hline 70. & Bandar & Karya Penggawa & idem & idem \\
\hline 71. & Pedada & Pesisir Tengah & idem & idem \\
\hline 72. & Ulu Krui & Pesisir Tengah & idem & idem \\
\hline 73. & Pasar Krui & Pesisir Tengah & idem & idem \\
\hline 74. & Way Napal & Pesisir Selatan & idem & idem \\
\hline 75. & Tenumbang & Pesisir Selatan & idem & idem \\
\hline 76. & Ngambur & Bengkunat & idem & idem \\
\hline 77. & Ngaras & Bengkunat & idem & idem \\
\hline 78. & Bengkunat & Bengkunat & idem & idem \\
\hline 79. & Belimbing & Bengkunat & idem & idem \\
\hline 80. & Pugung Penengahan & Pesisir Utara & idem & idem \\
\hline 81. & Pugung Melaya & Lemong & idem & idem \\
\hline 82. & Pugung Tampak- & Pesisir Utara & idem & idem \\
\hline 83. & Pulau Pisang & Pesisir Utara & idem & idem \\
\hline 84. & Way Tenong & Way Tenong & Semendo & Sumatera Selatan \\
\hline
\end{tabular}

Sumber: Wikipedia, 2013 
Susunan marga-marga territorial yang berdasarkan keturunan kerabat tersebut, pada masa kekuasaan Jepang sampai masa kemerdekaan pada tahun 1952 dihapus dan dijadikan bentuk pemerintahan negeri. Sejak tahun 1970, nampak susunan negeri sebagai persiapan persiapan pemerintahan daerah tingkat III tidak lagi diaktifkan, sehingga sekarang kecamatan langsung mengurus pekon-pekon/ kampung/desa sebagai bawahannya.

Prinsip-prinsip dalam kehidupan sehari-hari menunjukkan suatu corak keaslian penduduk masyarakat Lampung, yang dapat disimpulkan dalam 5 (lima) prinsip yaitu:

1. Pi'il Pesengiri, diartikan sebagai segala sesuatu yang menyangkut harga diri, prilaku, dan sikap hidup yang dapat menjaga dan menegakkan nama baik dan martabat secara pribadi maupun secara berkelompok yang senantiasa dipertahankan. Dalam halhal tertentu seseorang (Lampung) dapat mempertaruhkan apa saja (termasuk nyawanya) demi untuk mempertahankan Pi'il Persengirinya tersebut. Selain dari itu dengan Pi'il Pesengirinya seseorang dapat berbuat sesuatu atau tidak berbuat sesuatu, kendatipun hal itu merugikan dirinya secara materi.

2. Sakai Sambayan, meliputi beberapa pengertian yang luas termasuk didalamnya gotongroyong,tolong menolong, bahumembahu, dan saling memberi sesuatu yang diperlukan bagi pihak lain dan hal tersebut tidak terbatas pada sesuatu yang sifatnya materi saja, tetapi juga dalam arti moril termasuk sumbangan pikiran dan sebagainya.

3. Nemui Nyimah, berarti bermurah hati dan ramah tamah terhadap semua pihak baik terhadap orang dalam kelompoknya maupun terhadap siapa saja pihak yang berhubungan dengan mereka. Jadi bermurah hati dengan memberikan sesuatu yang ada padanya kepada pihak lain, juga bermurah hati dalam bertutur kata serta sopan santun dan ramah tamah terhadap tamu mereka.

4. Nengah Nyappur, adalah sebagai tata pergaulan masyarakat Lampung dengan kesediaan membuka diri dalam pergaulan masyarakat umum dan berpengetahuan luas. Ikut serta dalamberpartisipasi terhadap hal yang bersifat baik, yang dapat membawa kemajuan masyarakat sesuai dengan perkembangan zaman.

\section{Bejuluk Beadek}

Masyarakat adat Lampung khususnya masyarakat adat Tulang Bawang berda dalam bentuk federasi lembaga adat yang disebut dengan MEGOU PAK, terdiri dari 4 (empat) Klan besar yaitu ;

a. Marga Tegamo'an

b. Marga Buai Bolan

c. Marga Sway Umpu

d. Marga Aji

Marga memiliki pengertian yaitu:

1. Masyarakat adat yang terdiri dari beberapa kebudayaan yang telah menyatakan diri dalam kesatuan hukum adat tertentu.

2. Wilayah hukum adat yang telah dinyatakan berada dalam suatu wilayah tertentu.

3. Berdasarkan pengertian huruf (1) Marga terdiri dari klein kebuain dan kebuaian terbagi dari beberapa pepadun (Kepepaduan). Penyimbang dalam Kepaduan disebut dengan Penyimbang Pepaduan sedangkan penyimbang dalam kebuayaan disebut Penyimbang asal. Menurut pengertian huruf (2) marga memiliki wilayah adat yang terbagi menjadi beberapa Kampung (Tiuh), umbul dan huma.

Tentang penggunaan tanah adat dan hasil hutan, hokum adat MEGOU PAK pada mulanya diatur atas perizinan Kepala Marga dan hanya 
mengenal hak pakai, hak pakai mengambil hasil hutannya saja (tidak memiliki) sedangkan hak penggunaan air dan rawa merupakan hak bersama seluruh masyarakat adat MEGOU PAK. Dan hak kepemilikan harta benda turun temurun dikenal dengan Jeneng (hibah). (Hak mengatur dan perizinan telah diambil alih oleh Pemerintah) Maka didalam hukum adat Megou Pak penggunaan bumi,air dan ruang angkasa meliputi :

a. Hak pakai

b. Hak mengambil hasil hutan

c. Jeneng (hak kepemilikan)

d. Hak penggunaan air dan yang ada di dalamnya merupakan hak masyarakat adat Megou Pak tanpa batas klein.

Tradisi yang berlaku dalam masyarakat adat Megou Pak apabila berkenaan dengan permasalahan adat maka segala sesuatu diputuskan berdasarkan PEPUNG MARGA yang dihadiri oleh perwakilan dari ke EMPAT MARGA tersebut diatas yaitu ;

1) Segala sesuatu yang berkenaan dengan hubungan seseorang yang berada dalam kepepaduannya dengan orang lain yang diluar kepepaduannya berdasarkan Pepung adat. Contoh; dalam perkawinan adat maka perwakilan dari ke empat marga merupakan keharusan untuk mengetahui perkawiinan tersebut.

2) Kemudian segala sesuatu yang berhubungan dengan satu kesatuan wilayah Marga (Kampung, Umbul dan Huma) karena mnyangkut kepentingan orang banyak juga diputuskan melalui PEPUNG MARGA.

Permasalahan:

a. Umbul bolak, maharou dan sebagainya hanya dibuktikan oleh keterangan kepala kampung, sedangkan umbul maharou atau bolak merupakan bagian dari kesatuan wilayah adat yang seharusnya di putuskan melalui pepung adat lebih dahulu.

b. Salah pengertian tentang kewenangan penyimbang Pepadun terhadap kepeilikan tanah marga. Karena kewenangan Penyimbang Pepadun hanya memilki kewenangan dalam kepepadunnya saja. Sedangkan apabila menyangkut orang banyak harus melalui keputusan Pepung Adat.

c. Adanya pemahaman yang salah tentang kepemilikan tanah marga yang diartikan bahwa semua MARGA tertentu berhak terhadap tanah tersebut. Misalnya tanah marga Tegamo'an yang memiliki kesatuan wilayah Kampung atau Tiuh, umbul dan maharou serta bolak. Maka yang berhak atas tanah ulayat tersebut adalah masyarakat Kampung (tiuh), umbul yang berada dalam wilayah tanah itu (tidak semua marga Tegamo'an berhak atasnya). Namun pembuktian dan penyelesaiianya berdasarkan keputusan PEPUNG ADAT (MARGA).

d. Tidak ada satupun lembaga adat yang kompeten untuk mengatur perselisihan dan persengketaan yang terjadi. Adapun lembaga adat seperti LEMBAGA ADAT MEGOU PAK TULANG BAWANG dapat menjadi motorisasi, namun perlu legalitas semua pihak yang sah sebagai mitra kerja yang di butuhkan dan perlu sumber daya manusia yang memenuhi standar kapabilitas, kredibelitas yang memadai.

\subsection{Pemilikan/Penguasaan Tanah}

1. Tanah ulayat di lampung hampir tidak diakui oleh pemerintah masa lalu. Pengelolaan tanah diatur oleh para pemuka adat lampung. Sebelum masyarakat adat lampung membuka tanah baru, pimpinan adat kampung bermusyawarah menentukan lokasi 
global. Kemudian pimpinan suku bersama sejumlah anak buahnya membuka tanah dengan pembagian yang merata sesuai dengan kemampuan. Secara teoritis batas tanah ulayat kampung ditetapkan pada pertemuan pembukaan hutan dengan kampung lain atau berdasarkan kesepakatan antara kebuayan yang batas antaranya ditandai dengan batas sungai, gunung, pohon keras (tahunan) dsb.

2. Pada tahun 1952, Pemda mengeluarkan kebijakan yang dianggap sangat merugikan masyarakat hukum adat yaitu dengan dikeluarkannya Ketetapan Residen Lampung No. 153/D/1952 tanggal 3 September 1952 yang diperbaiki dengan Surat Ketetapan tanggal 20 Juli 1956 dimana sistem pemerintahan marga yang dikepalai oleh Pasirah dihapus, dengan demikian secara eksplisit bahwa termasuk semua tanah-tanah marga yang kewenangannya dilakukan oleh kepala marga juga dihapus dan tanah-tanah marga itu menjadi tanah negara. Berdasarkan Keputusan Menteri kehutanan maka kawasan hutan di provinsi Lampung terbagi atas hutan suaka, hutan lindung, hutan produksi tetap, hutan produksi terbatas, dan hutan produksi yang dapat dikonversi (HPK). Menurut catatan telah diselesaikan 51 register ketika Lampung masih merupakan wilayah karesidenan yang secara administratif masuk ke dalam Provinsi Sumatera Selatan ${ }^{1}$.

\subsection{Profil Kasus Pertanahan}

Lampung terkenal sebagai wilayah yang memiliki tingkat konflik agraria / pertanahan tertinggi di Indonesia. Telah banyak terjadi sengketa, konflik antara pihak berkuasa maupun pengusaha dengan para rakyat kecil, tak sedikit pula kerugian ditimbulkan oleh situasi ini baik. Hal ini hendaknya menjadi perhatian lebih bagi Pemerintah Indonesia untuk segera menuntaskan Program Reforma Agraria mengingat Indonesia sendiri menyimbolkan diri sebagai Negara Agraris.

Selain itu juga, terjadi konflik/sengketa pertanahan dimana banyak warga yang menduduki suatu wilayah dan mengakui wilayah tersebut merupakan tanah adat mereka, sedangkan ketika ditelusuri riwayat dari tanah tersebut dan warga/masyarakat tersebut tidak terdapat hubungan yang menyatakan bahwa wilayah tersebut merupakan milik tanah adat mereka.

Salah satu contoh permasalahan pertanahan yang banyak diketahui oleh umum adalah masalah pertanahan di Wilayah Mesuji. Dimana permasalahan pertanahan tersebut sekarang sudah bertaraf nasional dan untuk penyelesaiannya diambil alih oleh Menkopolhukam. Disini peran serta BPN sebagai anggota dari Tim yang dibentuk oleh Menkopolhukam.

Di dalam penelitian ini ditemukan juga, Permasalahan Tanah berskala nasional tetapi dapat diselesaikan dengan cara mediasi yang dilakukan oleh Kanwil BPN Provinsi Lampung. Permasalahan tanah PT. Sahang Bandar Lampung (PT. SBL) - Kabupaten Lampung Tengah, dengan masyarakat Sendang Ayu, Surabaya, dan Padang Ratu seluas 238 Ha di kecamatan Padang ratu, Kabupaten Lampung Tengah sejak 1970. Permasalahan tanah ini dapat diselesaikan oleh Kanwil BPN Prov. Lampung dapat tercapai kesepakatan secara win - win solution yang selesai melalui proses mediasi dengan mengadakan 3 (tiga) pertemuan.

1. Riza Yudha Patria, Thesis "Kebijakan Penerapan Hukum Pertanahan Nasional dan Pengaruhnya Terhadap Eksistensi hak Ulayat Di Kabupaten Lampung Barat Provinsi Lampung, 2002. 
TABEL 4.11. REKAPITULASI DATA SENGKETA, KONFLIK, DAN PERKARA PERTANAHAN TAHUN 2006 S/D 2012 PADA KANWIL BPN PROVINSI LAMPUNG

\begin{tabular}{|c|c|c|c|c|c|c|}
\hline No. & TAHUN & JENIS KASUS & $\begin{array}{l}\text { JUMLAH } \\
\text { AWAL }\end{array}$ & $\begin{array}{l}\text { KASUS } \\
\text { SELESAI }\end{array}$ & $\begin{array}{l}\text { KASUS } \\
\text { BARU }\end{array}$ & $\begin{array}{c}\text { SISA } \\
\text { KASUS }\end{array}$ \\
\hline 1 & 2 & 3 & 4 & 5 & 6 & 7 \\
\hline \multirow[t]{4}{*}{1} & \multirow[t]{4}{*}{2010} & 1. Sengketa & 24 & 3 & 10 & 31 \\
\hline & & 2. Konflik & 35 & 7 & 4 & 32 \\
\hline & & 3. Perkara & 47 & 9 & 15 & 53 \\
\hline & & Jumlah & 106 & 19 & 29 & 116 \\
\hline \multirow[t]{4}{*}{2} & \multirow[t]{4}{*}{2011} & 1. Sengketa & 31 & 14 & 21 & 38 \\
\hline & & 2. Konflik & 32 & - & 4 & 36 \\
\hline & & 3. Perkara & 53 & 4 & 11 & 60 \\
\hline & & Jumlah & 116 & 18 & 36 & 134 \\
\hline \multirow[t]{4}{*}{3} & \multirow[t]{4}{*}{2012} & 1. Sengketa & 38 & 8 & 20 & 50 \\
\hline & & 2. Konflik & 36 & 3 & 2 & 35 \\
\hline & & 3. Perkara & 60 & 10 & 3 & 53 \\
\hline & & Jumlah & 134 & 21 & 25 & 138 \\
\hline
\end{tabular}

Sumber: Laporan SKP BPN Provinsi Lampung, 2012

Berikut ini merupakan rekapitulasi masalah pertanahan wilayah provinsi Lampung yang tiap tahunnya terdapat peningkatan kasus/ pengaduan yang dapat dilihat pada tabel 4.11. Dari table 4.11 menunjukkan jumlah kasus pertanahan selama tiga tahun terakhir menunjukkan kenaikan dari tahun ke tahun, yang paling tinggi mengalami peningkatan adalah perkara, sedangkan konflik lebih besar dari sengketa pada tahun 2010 dan 2011 , konflik lebih kecil dari sengketa pada tahun 2012.

Dari table 4.12 menunjukkan bahwa selain aspek yuridis juga diteliti mengenai aspek sosiologi dan aspek lain, latar belakang terjadi permasalahan tersebut, hal ini berdasarkan informasi dari Kantor Wilayah dan kab. Tanggamus.

\section{TABEL 4.12. ASPEK YANG DITELITI DALAM PENELITIAN MENGENAI AKAR} MASALAH

\begin{tabular}{|c|c|c|}
\hline NO & WILAYAH & $\begin{array}{l}\text { APAKAH SELAIN ASPEK YURIDIS JUGA DITELITI } \\
\text { MENGENAI ASPEK SOSIOLOGI DAN ASPEK LAIN } \\
\text { SEHINGGA TERJADI MASALAH TERSEBUT }\end{array}$ \\
\hline 1. & Kanwil Provinsi Lampung & $\begin{array}{l}\text { Ya, Sebab Aspek Sosiologi dan Aspek Pendukungnya } \\
\text { perlu ditelaah atau dikaji dengan cermat apakah } \\
\text { sengketa itu timbul terkait. }\end{array}$ \\
\hline 2. & Kantah Kota Bandar Lampung & - \\
\hline 3. & Kantah Kab. Tulang Bawang & Tidak \\
\hline 4. & Kantah kab. Lampung Tengah & - \\
\hline 5. & Kantah Tanggamus & $\mathrm{Ya}$ \\
\hline
\end{tabular}


TABEL 4.13. TIM KHUSUS PENYELESAIAN KASUS PERTANAHAN

\begin{tabular}{|c|c|c|}
\hline NO & WILAYAH & $\begin{array}{l}\text { APAKAH ADA TIM KHUSUS PENYELESAIAN } \\
\text { KASUS PERTANAHAN DI TINGKAT PROVINSI, DAN } \\
\text { KABUPATEN/KOTA }\end{array}$ \\
\hline 1. & Kanwil Provinsi Lampung & Ada tim khusus tingkat Provinsi \\
\hline 2. & Kantah Kota Bandar Lampung & - \\
\hline 3. & Kantah Kab. Tulang Bawang & Belum ada \\
\hline 4. & Kantah kab. Lampung Tengah & $\begin{array}{l}\text { Terdapat tim penyelesaian kasus pertanahan } \\
\text { tingkat kabupaten/kota }\end{array}$ \\
\hline 5. & Kantah Tanggamus & Ada \\
\hline
\end{tabular}

Sumber: Hasil Pengumpulan Data di Lapangan, 2013

Berdasarkan tabel 4.13, dapat dijelaskan bahwa disejumlah wilayah provinsi lampung telah dilakukan pembentukan tim khusus untuk penyelesaian kasus pertanahan. Selain itu juga pernah terbentuk tim 13 yang dibentuk dengan Surat Keputusan Gubernur untuk melakukan proses penyelesaian permasalahan pertanahan yang terdiri dari instansi, LSM dan pihak akademisi. Pada awalnya terbentuknya tim 13 tersebut dapat membantu dalam meminimalisir jumlah permasalahan pertanahan yang ada dan unjuk rasa. Setelah 2 tahun berjalan, LSM yang awalnya merupakan bagian dari tim 13 tersebut sudah tidak dapat berkoordinasi dengan baik dalam penyelesaian permasalahan pertanahan yang terjadi dan berakhir dengan pembubaran tim tersebut.
Saat ini, Berdasarkan Surat Tugas Keputusan Gubernur telah dibentuk kembali tim penanganan permasalahan pertanahan yang diperbaharui setiap tahunnya terdiri dari instansi yang terkait dimana BPN merupakan anggota dari tim penanganan tersebut. Selain itu juga, terdapat beberapa daerah kota/kabupaten di provinsi lampung yang telah membentuk tim penyelesaian permasalahan pertanahan sebagaimana terdapat pelimpahan kewenangan yang diberikan dari pemerintah daerah tingkat provinsi ke pemerintah daerah kabupaten/ kota berdasarkan peraturan otonomi daerah.

Tabel 4.14 menunjukkan bahwa Kanwil, Kantah Kab. Tanggamus dan Kab. Lampung Tengah sudah melaksanakan eksekusi sesuai dengan

TABEL 4.14. EKSEKUSI BERITA ACARA TIM PENYELESAIAN KASUS

\begin{tabular}{|c|c|c|}
\hline NO & WILAYAH & $\begin{array}{l}\text { APAKAH ADA TIM KHUSUS PENYELESAIAN } \\
\text { KASUS PERTANAHAN DI TINGKAT PROVINSI, DAN } \\
\text { KABUPATEN/KOTA }\end{array}$ \\
\hline 1. & Kanwil Provinsi Lampung & Ya, dapat di eksekusi \\
\hline 2. & Kantah Kota Bandar Lampung & - \\
\hline 3. & Kantah Kab. Tulang Bawang & Belum ada \\
\hline 4. & Kantah kab. Lampung Tengah & $\begin{array}{l}\text { Dapat dieksekusi berdasarkan berita acara setelah } \\
\text { dilakukan cek lapangan }\end{array}$ \\
\hline 5. & Kantah Tanggamus & Sudah \\
\hline
\end{tabular}

Sumber: Hasil Pengumpulan Data di Lapangan, 2013 
TABEL 4.15. PETA/DATA SEBARAN SENGKETA/KONFLIK

\begin{tabular}{|c|l|l|}
\hline NO & \multicolumn{1}{|c|}{ WILAYAH } & \multicolumn{1}{|c|}{ PETA/DATA SEBARAN SENGKETA/KONFLIK } \\
\hline 1. & Kanwil Provinsi Lampung & Ya, Ada \\
\hline 2. & Kantah Kota Bandar Lampung & Tidak ada \\
\hline 3. & Kantah Kab. Tulang Bawang & Ya, Ada \\
\hline 4. & Kantah kab. Lampung Tengah & Tidak Ada \\
\hline 5. & Kantah Tanggamus & Tidak Ada \\
\hline
\end{tabular}

Sumber: Hasil Pengumpulan Data di Lapangan, 2013

berita acara kesepakatan.

Berdasarkan dari tabel 4.15. dapat dijelaskan bahwa, saat ini sebagian besar kantor pertanahan di wilayah provinsi lampung beserta kantor wilayah provinsi lampung telah memiliki data sebaran permasalahan pertanahan. Akan tetapi data sebaran tersebut hanya menunjukkan data dalam angka saja, dan belum dapat menunjukkan sebaran identifikasi permasalahan tersebut secara spasial. Sehingga untuk tahun 2013, direncanakan pembuatan peta sebaran permasalahan pertanahan untuk wilayah provinsi Lampung, dimana bidang sengketa konflik dan pertanahan dengan bekerja sama dengan bidang survey pengukuran dan pemetaan yang ada di kantor wilayah tersebut.

\section{PROVINSI KALIMANTAN SELATAN}

\subsection{Karakteristik Wilayah}

Secara geografis, Kalimantan Selatan berada di bagian tenggara pulau Kalimantan, memiliki kawasan dataran rendah di bagian barat dan pantai timur, serta dataran tinggi yang dibentuk oleh Pegunungan Meratus

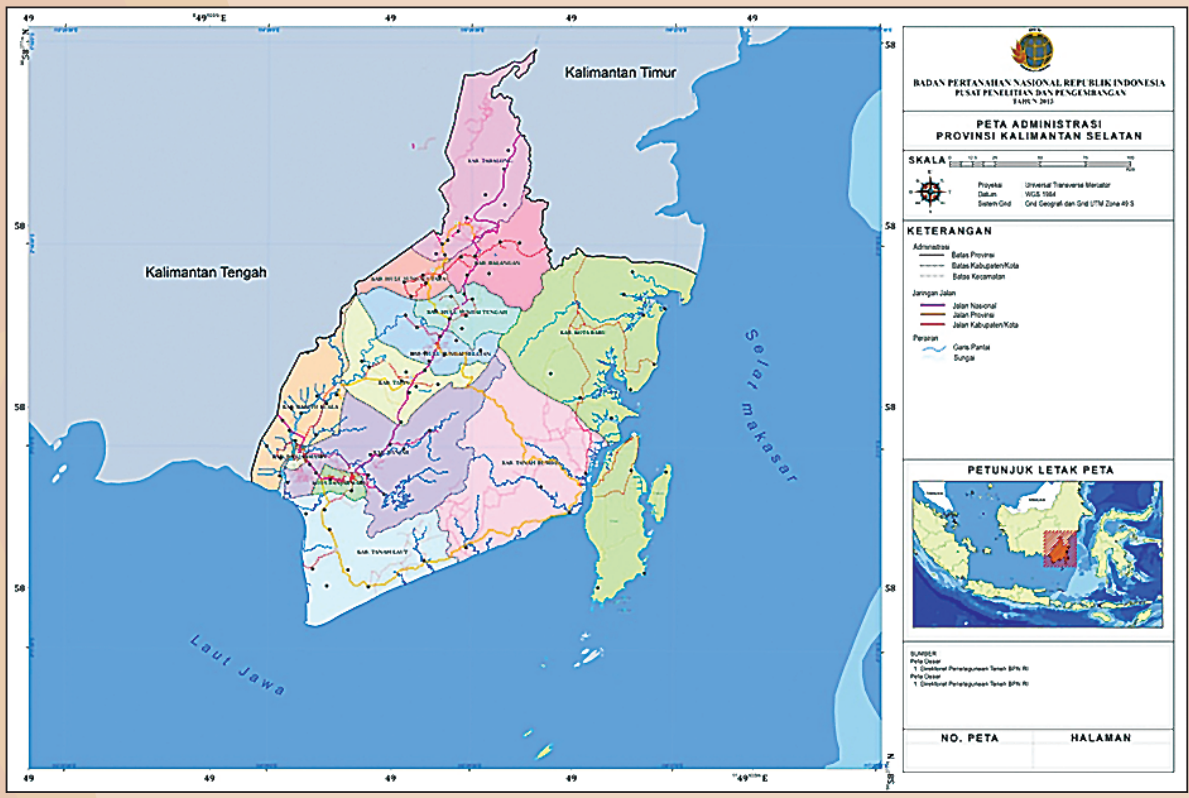

Gambar 4.3. Peta Administrasi Kalimantan Selatan 
di tengah. Dua ciri geografi utama, yakni dataran rendah dan dataran tinggi. Kawasan dataran rendah kebanyakan berupa lahan gambut hingga rawa-rawa sehingga kaya akan sumber keanekaragaman hayati satwa air tawar. Kawasan dataran tinggi sebagian masih merupakan hutan tropis alami dan dilindungi oleh pemerintah.

Luas wilayah Provinsi Kalimantan Selatan hanya 6,98\% dari luas Pulau Kalimantan secara keseluruhan. Secara administratif wilayah Provinsi Kalimantan Selatan dengan Kota sebagian besar berupa hutan. Wilayah Kalimantan Selatan juga banyak dialiri sungai. Sungai tersebut antara lain Sungai Barito, Sungai Riam Kanan, Sungai Riam Kiwa, Sungai Balangan, Sungai Batang Alai, Sungai Amandit, Sungai Tapin, Sungai Kintap, Sungai Batulicin, Sungai Sampanahan dan sebagainya. Umumnya sungai-sungai tersebut berpangkal pada pegunungan Meratus dan bermuara di Laut Jawa dan Selat Makasar.

Penduduk asli Kalimantan Selatan umumnya suku bangsa Banjar yang intinya terdiri dari sub suku, yaitu Maayan, Lawangan dan Bukiat yang

\section{TABEL 4.16. DAFTAR KOTA DAN KABUPATEN DI PROVINSI KALIMANTAN}

\section{SELATAN}

\begin{tabular}{|c|l|c|c|c|}
\hline NO. & \multicolumn{1}{|c|}{ KABUPATEN/KOTA } & IBU KOTA & $\begin{array}{c}\text { JUMLAH } \\
\text { KECAMATAN }\end{array}$ & $\begin{array}{c}\text { JUMLAH } \\
\text { DESA }\end{array}$ \\
\hline 1 & Kabupaten Balangan & Paringin & 8 & 152 \\
\hline 2 & Kabupaten Banjar & Martapura & 19 & 288 \\
\hline 3 & Kabupaten Barito Kuala & Marabahan & 17 & 200 \\
\hline 4 & Kabupaten Hulusungai Selatan & Kandangan & 11 & 148 \\
\hline 5 & Kabupaten Hulusungai Tengah & Barabai & 11 & 169 \\
\hline 6 & Kabupaten Hulu Sungai Utara & Amuntai & 10 & 219 \\
\hline 7 & Kabupaten Kotabaru & Kotabaru & 20 & 197 \\
\hline 8 & Kabupaten Tabalong & Tanjung & 12 & 131 \\
\hline 9 & Kabupaten Tanah Bumbu & Batulicin & 10 & 135 \\
\hline 10 & Kabupaten Tanah Laut & Pelaihari & 11 & 135 \\
\hline 11 & Kabupaten Tapin & Rantau & 12 & 131 \\
\hline 12 & Kota Banjarbaru & - & 5 & 50 \\
\hline 13 & Kota Banjarmasin & - & 5 & 20 \\
\hline
\end{tabular}

Sumber : Wikipedia, 2013

Banjarmasin sebagai ibukotanya meliputi 11 Kabupaten dan 2 Kota. Persentase luas terbesar adalah Kabupaten Kotabaru (25,11\%), Kabupaten Tanah Bumbu (13,50\%) dan terkecil adalah Kota Banjarmasin (0,19\%) dan Kota Banjarbaru $(0,88 \%)$, dan terdapat 5 unit pemukiman transmigrasi. Unit pemukiman transmigrasi terdapat di Kabupaten Batola, Balangan, Tanah Bumbu, Banjar dan Kotabaru. Tanah di wilayah Provinsi Kalimantan Selatan mengalami percampuran dengan suku bangsa Melayu, Jawa dan Bugis. Identitas utama yang terlihat adalah bahasa Banjar sebagai media umum. Penduduk pendatang seperti Jawa, Melayu, Madura, dan Bugis sudah lama datang ke Kalimantan Selatan. Suku bangsa Melayu datang sejak zaman Sriwijaya atau sebagai pedagang yang menetap, suku bangsa Jawa datang pada periode Majapahit bahkan sebelumnya, kemudian orang Bugis datang 
mendirikan kerajaan Pegatan di masa lalu.

Kelompok etnik di Kalimantan Selatan menurut Museum Lambung Mangkurat, antara lain:

1. Orang Banjar Kuala, di daerah Banjarmasin sampaiMartapura;

2. Orang Banjar Batang Banyu, di daerah Margasari sampai Kelua;

3. Orang Banjar Pahuluan, di daerah Tanjung sampai Pelaihari(luar Martapura);

4. Suku Bukit, di daerah Dayak Pitap, Haruyan Dayak, Loksado, Harakit, Paramasan, Bajuin, Riam Adungan, Sampanahan, Hampang, Bangkalan Dayak;

5. Suku Berangas, di daerah Berangas, Ujung Panti, Lupak,Aluh Aluh;

6. Suku Bakumpai, di aerah Bakumpai, Marabahan, Kuripan,Tabukan;

7. Suku Maanyan, di daerah Maanyan Warukin, MaanyanPasar Panas, Maanyan Juai (Dayak Balangan), Dayak Samihim;

8. Suku Abal, di daerah Kampung Agung sampai Haruai;

9. Suku Dusun Deyah, di kecamatan Muara Uya, Upau danGunung Riut;

10. Suku Lawangan, di desa Binjai, Dambung Raya;

11. Orang Madura Madurejo, di desa Madurejo, Mangkauk;

12. Orang Jawa Tamban, di daerah Tamban, Barito Kuala;

13. Orang Cina Parit, di daerah Pelaihari;

14. Suku Bajau, di daerah Semayap, Tanjung Batu;

15. Orang Bugis Pagatan, di daerah Pagatan;

16. Suku Mandar, di daerah pesisir pulau Laut dan pulau Sebuku.

Selain ke-16 suku tersebut, terdapat juga Suku Bali (di desa Barambai, Sari Utama), Suku Sunda di desa Hegar Manah, dan suku Flores di Kembang Kuning.

Dalam masyarakat Banjar sistem kekerabatannya mengenal berbagai istilah dalam melihat hubungan kekerabatan tersebut, yaitu 4

1. Untuk hubungan garis ke atas dikenal istilah "Kuwitan", yaitu sebutan untuk orang tua, baik itu ayah maupun ibu. Dalam hal-hal tersebut ada yang disebut "Kuwitan diujud" yang digunakan untuk menyebut orang tua yang sebenar-benarnya, penyebutan ini terjadi karena dalam masyarakat Banjar mengenal pula orang tua angkat yang disebut "Kuwitan angkat". Oleh karena itu penyebutan "Kuwitan diujud" adalah untuk membedakan dengan "Kuwitan angkat". Dalam bahasa seharihari untuk memanggil orang tua lakilaki (kuwitan laki) dipakai istilah " abah", sedangkan untuk orang tua perempuan (Kuwitan bini) dipakai istilah "uma"atau" mama". Garis ke-atas kuwitan ini adalah disebut dengan istilah "pakai'an" atau "Paninian". Istilah Pakai'an ini digunakan untuk menyebut orang tua laki-laki dari ayah atau ibu (kakek), sedangkan istilah paninian dipakai untuk bahasa sehari-hari penyebutan untuk kakek dipakai istilah "kai", sedangkan untuk nenek dipakai istilah " nini". Garis ke-atas setelah kakek atau nenek ini dikenal istilah " padatuan" atau " datu" atau" datuk", sebutan ini dipergunakan tanpa membedakan lagi antara yang laki-laki dengan yang perempuan. Garis ke-atas setelah "padatuan" dikenal berbagai istilah seperti "anggah", "waring", dan "moyang". Garis ini tidak hanya ada dalam penyebutan, dimana orangnya sudah lama meninggal dunia.

2. Untuk hubungan garis ke-bawah dikenal istilah "anak" untuk menyebutkan keturunan yang pertama, setelah itu generasi berikunya dikenal dengan

1. Daud, Alfani, 1997, Islam dan Masyarakat Banjar: Deskripsi dan Analisa Kebudayaan Banjar, Jakarta: RajaGrafindo Persada. 
istilah "cucu", sedangkan untuk generasi ketiga dibawah cucu tersebut dikenal istilah "buyut". Garis keturunan setelah "buyut" tersebut ditemukan istilah "cicit" dan "piut", yang istilah ini juga dalam kenyataannya sekarang hanya ada dalam penyebutan.

3. Untuk hubungan garis kesamping dikenal istilah " dangsanak" untuk menyebutkan istilah saudara. Istilah "dangsanak" ini dapat terbagi dalam beberapa katagori, yaitu:

a. "Dangsanak sauma-sabapa" untuk menyebutkan istilah saudara kandung;

b. "Dangsanak sauma" untuk menyebutkan istilah saudara ibu;

b. "Dangsanak sabapa" untuk menyebutkan istilah saudara seayah;

c. "Dangsanak tiri" untuk menyebutkan istilah sehari-hari hubungan antara saudara seayah atau se-ibu saja.

Dalam pergaulan sehari-hari antara saudara ini dikenal sebutan panggilan, yaitu "ading" untuk menyebut saudara yang lebih muda dan "kaka" untuk menyebutkan yang lebih tua. Disamping itu juga sering disebutkan istilah "dangsanak anum" untuk saudara yang muda, dan "dangsanak tuha" untuk saudara yang tua. Istilah "ading" dan "kaka" ini juga sering dipergunakan dalam panggilan antara suami isteri, dimana "ading" adalah isteri, sedangkan "kaka" adalah suami.

4. Untuk garis hubungan kesamping sesudah saudara, adalah anak dari saudara bapak, cucu saudara kakek. Untuk ini dikenal beberapa istilah, yaitu:
a. " sapupu sekali" untuk penyebutan anak dari saudara ayah/ibu;
b. " sapupu dua kali" untuk penyebutan cucu dari saudara kakek atau nenek;
c. " sapupu tiga kali" untuk penyebutan buyut dari saudara datuk;

5. Untuk garis keturunan kesamping ke atas yang meliputi saudara-saudara dari ayah atau ibu yang dalam istilah sehari-hari dikenal dengan sebutan "mamarina". "Mamarina" ini terdiri dalam beberapa katagori istilah, yaitu:

a. "Julak" untuk menyebutkan saudara ayah/ ibu yang tertua;

b. "Gulu" untuk menyebutkan adik dari "Julak"”;

c. "Tangah" untuk menyebutkan adik dari "Gulu";

Disamping itu untuk katagori mamarina ini dikenal pula istilah " makacil" untuk sebutan saudara ayah/ ibu yang perempuan, dan "pacilan" untuk sebutan saudara ayah/ibu yang laki-laki.

Dalam katagori keseluruhan sistem keluarga yang ada dalam masyarakat Banjar penyebutannya dikenal istilah "bubuhan". Bubuhan ini menggambarkan keterikatan dari suatu keluarga besar masyarakat Banjar

Dari hubungan kekerabatan tersebut di atas menunjukan bahwa dalam masyarakat Banjar menarik garis keturunan dari dua sisi, yaitu sisi ayah dan sisi ibu. Hal ini berarti sistem kekerabatan yang ada dalam masyarakat Banjar adalah menganut sistem Parental atau Bilateral.

Sebagaimana diketahui secara teoritas dikenal ada tiga sistem kekerabatan, yaitu sistem Partrilinial, sistem Materilinial dan sistem Parental/ Bilateral. Berbeda dengan sistem Parental, maka sistem Patrilinial menarik garis keturunan menurut garis Bapak, sedangkan dalam sistem Matrilinal menarik garis keturunan dari garis Ibu.

Akan tetapi perlu juga dicatat bahwa dalam hal-hal tertentu masyarakat Banjar terkesan 
menarik sistem kekeluargaannya berdasarkan sistem Patrilinial, seperti dalam menentukan gelar dalam garis keturunan. Seperti gelar "Gusti" ditarik berdasarkan garis keturunan ayah.

Dilihat dari sistem pewarisan individual, maka masyarakat Banjar dapat dikatagorikan menggunakan sistem pewarisan individual. Sebagaimana diketahui dalam sistem pewarisan individual setiap ahli waris mendapatkan pembagian, dimana ia dapat menguasai atau memiliki harta warisa menurut bagiannya masing-masing. Praktek yang terjadi dalam. Pembagian warisan menunjukan setiap waris dapat menguasai harta warisan yang merupakan bagiannya.

Namun demikian dalam prakteknya disamping sistem pewarisan individual ini juga ditemukan sistem pewarisan mayorat, dimana dalam sistem pewarisan mayorat harta tidak dibagi melainkan dikuasai oleh salah seorang ahli waris. Penguasaan harta warisan oleh salah seorang ahli waris ini biasanya dilakukan oleh orang tua laki-laki atau orang tua perempuan kalau salah satunya meninggal dunia, atau dikuasai oleh saudara tertua kalau kedua orang tuanya meninggal dunia.

Ada beberapa alasan terjadinya sistem pewarisan mayorat ini, seperti:

1. Pewaris berwasiat (berpesan) sebelum meninggal agar jangan sampai terjadi pertengkaran mengenai harta warisan, dimana harta warisan dinikmati secara bersama-sama saja. Dalam hal ini biasanya harta warisan berupa rumah dan perahu, sehingga dengan demikian setiap ahli waris dapat menikmati hasilnya atau menggunakannya;

2. Ahli waris mempunyai kesepakatan untuk tidak membagi sebagian atau seluruh harta warisan, dengan tujuan agar harta tersebut dapat digunakan untuk melaksanakan upacara keagamaan yang terjadi sehubungan dengan meninggalnya pewaris, seperti upacara haulan setiap tahun;

3. Ahli waris bersepakat harta warisan tidak dibagi dalam rangka membiayai ahli waris yang belum mandiri atau ahli waris lain dianggap belum dewasa atau cakap mengurus sendiri bagian harta warisan yang merupakan haknya;

4. Ahli waris sepakat untuk tidak membagi harta warisan karena menghormati salah satu ahli waris lain yaitu ibunya atau baoaknya, sehingga jarang sekali adanya tuntutan membagi harta warisan dari anakanaknya walaupun anak-anak tersebut sudah dewasa.

Dari hasil apa yang dikemukakan tersebut di atas tergambar sistem pewarisan dalam masyarakat Banjar dapat dikatakan suatu sistem yang bersifat campuran atau gabungan (mixed), yaitu antara sistem pewarisan individual dengan sistem pewarisan mayorat. Dalam hal sistem pewarisan kolektif secara tegas kolektif dan serta mereta tidak dilakukan pembagian waris, melainkan harta dikuasai secara bersama-sama. Walaupun demikian sistem mayorat sebenarnya adalah kelanjutan dari sistem kolektif ini, akan tetapi dalam sistem mayorat ditemukan adanya pertimbanganpertimbangan tertentu untuk tidak membagi warisan yang didasarkan kepada wasiat atau kesepakatan ahli waris dalam rangka menjaga kemaslahatan bersama. Oleh karena itu model sistem pewarisan mayorat yang dijumpai dalam masyarakat Banjar dapat dikatakan sebagai suatu pengecualian atau penyimpangan khusus dari sistem warisan yang individual.

Sistem pewarisan dalam masyarakat Banjar dapat pula dilihat dari aspek sistem pewarisan Islam. Adanya sistem pewarisan Islam ini 
terlihat pada peranan tokoh agama ("tuan guru") yang selalu diminati pendapat untuk membagi harta warisan, dimana tokoh agama ini dalam memberikan petuahnya selalu berpegang kepada sistem pembagian yang dianut oleh hukum Islam. Dalam hal ini biasanya para ahli waris menuruti cara pembagian yang dipetuahkan oleh tokoh agama tersebut, walaupun nantinya ditemukan pula dalam pelaksanaannya para ahli waris tidak menuruti pembagian yang sudah dipetuahkan tersebut. Namun demikian yang pasti penggunaan sistem hukum waris Islam ini ada kalau terjadi persengketaa terhadap besarnya pembagian harta warisan tersebut. Dengan adanya pesengketaan waris, maka mereka sepenuhnya tunduk kepada apa yang dipetuahkan oleh tokoh agama.

Dilihat dari sisi sistem pewarisan Barat yang menegaskan harus ada pembagian waris pada saat pewaris meninggal dunia, dan setiap ahli waris dapat menuntut agar segera warisan dibagikan, maka dalam masyarakat Banjar tidak ditemukan pola yang demikian itu, walaupun sebenarnya sistem hukum waris Barat ini juga menganut sistem waris individual. Dalam hal ini tidak ditemukan adanya suatu keharusan yang menetapkan harus segera di adakan pembagian waris akan tetapi pembagian waris dilakukan dilihat dari situasi atau keadaan tertentu yang menhendaki segera atau tidaknya harta warisan itu dibagi. Suatu hal yang sangat kontras berbeda sari sistem pewarisan Barat ini terletak pada ketentuan yang ahli waris untuk menolak warisan, sedangkan andangan. Masyarakat Banjar dalam hal ini tidak boleh menolak warisan, karena menerima hukumnya wajib.Kewajiban ini tidak hanya terbatas kepada mewaris harta Pewaris saja,akan tetapi juga mencakup kewajiban membayar utangutang atau "urusan" pewaris dengan pihak lain.
Salah satu bentuk penyelesaian sengketa yang lazim dilakukan oleh masyarakat Banjar. Adat badamai bermakna pula sebagai hasil proses perembukan atau musyawarah dalam pembahasan bersama dengan maksud mencapai suatu keputusan sebagai penyelesaian dari suatu masalah. Adat badamai dilakukan dalam rangka menghindarkan persengketaan yang dapat membahayakan tatanan sosial. Putusan Badamai yang dihasilkan melalui mekanisme musyawarah merupakan upaya alternatif dalam mencari jalan keluar guna memecahkan persoalan yang terjadi dalam masyarakat. Pada masyarakat Banjar jika terjadi persengketaan diantara warga atau terjadi tindak penganiayaan atau pelanggaran norma (adat) atau terjadi perkelahian ataupun pelanggaran lalu lintas, maka warga masyarakat berkecenderungan menyelesaikan secara badamai. Warga masyarakat enggan menyelesaikan sengketa itu melalui lembaga ligitasi (jalur lembaga peradilan). Adat badamai ini diakui efektif dalam menyelesaikan pertikaian atau persengketaan. Sekaligus mampu menghilangkan perasaan dendam dan berperan menciptakan keamanan ketertiban dan perdamaian. Adat badamai ini lazim pula disebut dengan, babaikan, baparbaik, bapatut atau mamatut, baakuran dan penyelesaian dengan cara suluh.

\subsection{Pemilikan/Penguasaan tanah}

Di wilayah Kalimantan Selatan, penguasaan tanah sebagian besar ditunjukkan dengan selembar kertas bermaterai yang biasa disebut "segel tanah". Proses pembuatan segel tanah ini pun kebanyakan dilakukan dengan cara melalui para aparat pemerintahan Desa, dengan membayar tarif tertentu. Padahal surat tanah ini, yang nama sebenarnya adalah Surat Keterangan Penguasaan Fisik Bidang Tanah, menerangkan penguasaan tanah atau lahan oleh yang bersangkutan, bukan diterangkan oleh pihak Pemerintahan Desa. Di surat Tanah 
ini posisi Kepala Desa dan Ketua RT hanya selaku mengetahui, yang lebih dititik beratkan adalah pihak yang menguasai tanah tersebut, dimana bilamana ia memuat data palsu atau rekayasa bersedia dituntut secara hukum yang berlaku. Ironisnya seseorang yang sudah memegang "segel tanah" kebanyakan tak mengurusi tanah dimaksud, bahkan dibiarkan tanpa digarap sebagaimana mestinya, seperti semak belukar.

Terdapat indikasi sebagian besar pembuatan segel tanah dilakukan diatas meja, berdasarkan dan berpedoman pada sehelai kertas peta desa, diplot untuk kemudian dibagi-bagikan kepada mereka yang mau dan mampu membayar harga yang ditawarkan. Dan tak rahasia pula pekerjaan pembuatan segel tanah tersebut dilakukan oleh para oknum Aparat pemerintahan Desa sehingga banyak terjadi sengketa tanah/lahan dikarenakan pengeluaran segel tanah yang terlalu sering, serta terjadi tumpang tindih satu sama lain.

Akibatnya, banyak pihak yang akhirnya dirugikan, antara lain pihak perusahaan perkebunan yang mendapatkan ijin Hak Guna Usaha (HGU), ataupun pihak perusahaan pemegang ljin Usaha pertambangan (IUP). Ketika mereka akan melakukan aktivitas menggarap usaha, terjadilah klaim dari banyak pihak yang mengaku menguasai tanah/lahan itu lebih duluan daripada perusahaan yang sudah menanamkan investasi, padahal tanah/ lahan yang diklaim tersebut bentuknya semak belukar bahkan hutan rimba.

\subsection{Profil Kasus Pertanahan}

Seiring dengan pertumbuhan ekonomi dan penduduk semakin tidak seimbang dengan ketersediaan lahan, dimasa mendatang diperkirakan sengketa tanah akan terus meningkat dan semakin kompleks'. Selain itu kondisi lahan yang tersedia semakin lama semakin kritis dan diperuncing lagi oleh maraknya spekulan dan calo tanah gara gara informasi pasar yang tidak transparan akan menambah semakin rumitnya kualitas sengketa tanah yang terjadi.

Disadari bahwa terdapat beberapa faktor penting yang dapat menyulut terjadi persoalan pertanahan di Provinsi Kalimantan Selatan dengan munculnya berbagai sebab dan motif pertanahan. Diantaranya terdapat disharmoni kebijakan dan multisektor yang dikeluarkan dari instansi - instansi pemerintah tentang pertanahan, aturan hukum yang kurang mendukung penyelesaian, mekanisme penyelesaian yang kurang memadai, kelembagaan yang lemah, administrasi registrasi tanah tidak optimal, perlindungan terhadap rakyat akan tanah belum memadai dan pengetahuan masyarakat atas hukum pertanahan.

Dalam upaya menangani sengketa pertanahan yang cenderung makin hari makin meningkat baik kuantitas maupun kualitas, BPN-RI dengan kewenangan yang ada telah mengambil langkah langkah penanganan dan penyelesaian sengketa, konflik dan perkara pertanahan secara konsisten dan berkelanjutan yaitu dengan melaksanakan Penanganan dan Penyelesaian Sengketa, Konflik dan Perkara yang mendapat prioritas. Sampai saat ini, BPN Provinsi Kalimantan Selatan lebih banyak menangani tunggakan permasalahan tahun - tahun sebelumnya dan beberapa kasus permasalahan pertanahan yang baru.

Berikut ini merupakan rekapitulasi masalah pertanahan wilayah provinsi Kalimantan Selatan yang tiap tahunnya terdapat peningkatan kasus/pengaduan yang dapat dilihat pada tabel 4.17 . 
Tabel 4.18 menunjukkan bahwa dalam penelitian mengenai akar masalah yang terjadi, selain aspek yuridis juga diteliti mengenai aspek sosiologi yang berkaitan dengan keadaan dan situasi yang terjadi atau berkembang dalam masyarakat dimana sengketa tersebut terjadi. Juga diperhatikan aspek hankam, terutama aspek sengketa tanah yang berindikasi besar terhadap situasi keamanan di masyarakat dimaksud. Berdasarkan tabel 4.19, dapat dijelaskan bahwa disejumlah wilayah provinsi Kalimantan Selatan telah terdapat pembentukan tim khusus untuk penyelesaian permasalahan pertanahan. Dalam penyelesaian permasalahan pertanahan ini, Kantor Wilayah BPN Provinsi Kalimantan Selatan telah membentuk tim khusus

TABEL 4.17. TIPOLOGI MASALAH PERTANAHAN TAHUN 2010

\begin{tabular}{|c|l|c|c|c|c|c|c|c|c|}
\hline \multirow{7}{*}{ NO. } & \multirow{7}{*}{ KABUPATEN/KOTA } & \multicolumn{7}{c|}{ TIPOLOGI } \\
\cline { 2 - 10 } & KA & B & C & D & E & F & G & H \\
\hline 1 & Kanwil & - & - & 2 & - & - & - & - & - \\
\hline 2 & Banjarmasin & - & - & 2 & - & - & - & - & - \\
\hline 3 & Banjar & 2 & - & 1 & - & - & - & - & - \\
\hline 4 & Banjarbaru & 2 & - & 2 & - & - & - & - & - \\
\hline 5 & Tapin & - & - & - & - & - & - & - & - \\
6 & Hulu Sungai Selatan & - & - & - & - & - & - & - & - \\
\hline 7 & Hulu Sungai Tengah & - & - & - & - & - & - & - & - \\
\hline 8 & Hulu Sungai Utara & 2 & - & 1 & - & - & - & - & - \\
\hline 9 & Tabalong & 2 & - & 1 & - & - & - & - & - \\
\hline 10 & Barito Kuala & - & - & - & - & - & - & - & - \\
\hline 11 & Tanah Laut & 3 & - & - & - & - & - & - & - \\
\hline 12 & Kotabaru & - & - & - & - & - & - & - & - \\
\hline 13 & Tanah Bumbu & - & - & - & - & - & - & - & - \\
\hline 14 & Balangan & - & - & - & - & - & - & - & - \\
\hline & Jumlah & 11 & - & 9 & - & - & - & - & - \\
\hline
\end{tabular}

Sumber: Laporan SKP BPN Provinsi Kalimantan Selatan, 2010

Keterangan:

A. Masalah Penguasaan dan Pemilikan Tanah

B. Masalah prosedur Penetapan Hak \&

Pendaftaran Tanah

C. Masalah batas/letak bidang tanah

D. Masalah pelaksanaan putusan pengadilan

E. Masalah tanah ulayat

F. Masalah tanah obyek Landreform

G. Masalah ganti rugi tanah ex. Partikelir

H. Masalah pengadaan tanah 
TABEL 4.18. ASPEK YANG DITELITI DALAM PENELITIAN MENGENAI AKAR MASALAH

\begin{tabular}{|c|c|c|}
\hline No & WILAYAH PENELITIAN & $\begin{array}{l}\text { APAKAH SELAIN ASPEK YURIDIS JUGA DITELITI } \\
\text { MENGENAI ASPEK SOSIOLOGI DAN ASPEK LAIN } \\
\text { SEHINGGA TERJADI MASALAH TERSEBUT }\end{array}$ \\
\hline 1. & $\begin{array}{l}\text { Kanwil Provinsi } \\
\text { Kalimantan Selatan }\end{array}$ & $\begin{array}{l}\text { Dalam penelitian mengenai akar masalah yang terjadi, } \\
\text { selain aspek yuridis juga diteliti mengenai aspek sosiologi } \\
\text { yang berkaitan dengan keadaan dan situasi yang terjadi } \\
\text { atau berkembang dalam masyarakat dimana sengketa } \\
\text { tersebut terjadi. Juga diperhatikan aspek hankam, } \\
\text { terutama aspek sengketa tanah yang berindikasi besar } \\
\text { terhadap situasi keamanan di masyarakat dimaksud. } \\
\text { Ya Perlu, aspek social dan aspek lainnya karena mereka } \\
\text { saling berkaitan satu sama lainnya, terutama unsure } \\
\text { pemerintahan dan unsure masyarakat dalam hal ini tokoh } \\
\text { agama, adat, tokoh masyarakat, dll. }\end{array}$ \\
\hline 2. & Kantah Kota Banjarmasin & $\begin{array}{l}\text { Dalam penelitian mengenai akar masalah yang terjadi, } \\
\text { selain aspek yuridis juga diteliti mengenai aspek sosiologi } \\
\text { yang berkaitan dengan keadaan dan situasi yang terjadi } \\
\text { atau berkembang dalam masyarakat dimana sengketa } \\
\text { tersebut terjadi. Juga diperhatikan aspek hankam, } \\
\text { terutama aspek sengketa tanah yang berindikasi besar } \\
\text { terhadap situasi keamanan di masyarakat dimaksud. }\end{array}$ \\
\hline 3. & Kantah Kota BanjarBaru & Tidak \\
\hline 4. & Kantah kab. Tanah Laut & Ya \\
\hline 5. & Kantah Kab. Barito Kuala & \\
\hline 6. & Kantah Kab. Banjar & \\
\hline
\end{tabular}

Sumber: Hasil Pengumpulan Data, 2013

menangani penyelesaian permasalahan pertanahan yang ada di wilayahnya, sedangkan untuk kantor pertanahan yang berada di wilayah provinsi ini melakukan pembentukan tim disesuaikan dengan kebutuhan dan urgensi dari permasalahan pertanahan yang dihadapi.

Hal ini berbeda dengan Pemerintah Daerah provinsi Kalimantan Selatan yang melakukan pelimpahan kewenangan atas penyelesaian permasalahan pertanahan yang terjadi di wilayahnya ke pemerintah kabupaten/kota, dan memonitoring atas permasalahan yang terjadi.

Seperti halnya pelimpahan kewenangan yang diberikan dari pemerintah daerah tingkat provinsi ke pemerintah daerah kabupaten/ 
TABEL 4.19. TIM KHUSUS PENYELESAIAN PERMASALAHAN PERTANAHAN

\begin{tabular}{|c|c|c|}
\hline NO & WILAYAH PENELITIAN & $\begin{array}{l}\text { APAKAH ADA TIM KHUSUS PENYELESAIAN } \\
\text { PERMASALAHAN PERTANAHAN DI TINGKAT } \\
\text { PROVINSI, DAN KABUPATEN/KOTA }\end{array}$ \\
\hline 1. & $\begin{array}{l}\text { Kanwil Provinsi } \\
\text { Kalimantan Selatan }\end{array}$ & $\begin{array}{l}\text { Dibentuk tim khusus berdasarkan SK Ka. Kanwil } \\
\text { Prov Kalimantan Selatan terhadap permasalahan - } \\
\text { permasalahan pertanahan } \\
\text { Ada,1. Untuk tingkat Provinsi dipegang oleh kepala } \\
\text { bidang pengkajian dan penanganan sengketa dan konflik. } \\
\text { 1.Di lingkup kab/kota dipegang oleh kepa seksi sengketa, } \\
\text { konflik dan perkara. }\end{array}$ \\
\hline 2. & Kantah Kota Banjarmasin & $\begin{array}{l}\text { Dibentuk tim khusus berdasarkan SK Ka. Kantah } \\
\text { terhadap permasalahan - permasalahan pertanahan }\end{array}$ \\
\hline 3. & Kantah Kota BanjarBaru & Tidak \\
\hline 4. & Kantah kab. Tanah Laut & $\begin{array}{l}\text { Belum Terdapat Tim Khusus Penyelesaian Permasalahan } \\
\text { Pertanahan }\end{array}$ \\
\hline 5. & Kantah Kab. Barito Kuala & \\
\hline 6. & Kantah Kab. Banjar & \\
\hline
\end{tabular}

Sumber: Hasil Pengumpulan Data, 2013

kota berdasarkan peraturan otonomi daerah, tim penyelesaian permasalahan pertanahan yang terdapat di kab. Tanah laut dibentuk berdasarkan SK Bupati, dimana terdiri dari beberapa instansi terkait dan kantor pertanahan kab. Tanah laut merupakan salah anggota dari tim penyelesaian tersebut. Pembentukan tim ini dibentuk disesuaikan dengan urgensi permasalahan pertanahan yang di hadapi.

Berdasarkan tabel 4.20, dapat dijelaskan bahwa hasil dari berita acara penyelesaian kasus pertanahan di provinsi Kalimantan Selatan yang telah disepakati oleh para pihak, berakhir dengan eksekusi dapat dilaksanakan dan tidak dapat dilaksanakannya keputusan tersebut.

Berdasarkan dari tabel 4.21. dapat dijelaskan bahwa, saat ini sebagian besar kantor pertanahan di wilayah provinsi Kalimantan Selatan beserta kantor wilayah provinsi Kalimantan Selatan telah memiliki data sebaran permasalahan pertanahan. Akan tetapi data sebaran tersebut hanya menunjukkan data dalam angka saja, dan belum dapat menunjukkan sebaran identifikasi permasalahan tersebut secara spasial. 
TABEL 4.20. EKSEKUSI BERITA ACARA TIM PENYELESAIAN KASUS

\begin{tabular}{|c|c|c|}
\hline NO & WILAYAH PENELITIAN & $\begin{array}{l}\text { EKSEKUSI SESUAI DENGAN BERITA ACARA HASIL } \\
\text { TIM PENYELESAIAN KASUS }\end{array}$ \\
\hline 1. & $\begin{array}{l}\text { Kanwil Provinsi } \\
\text { Kalimantan Selatan }\end{array}$ & $\begin{array}{l}\text { Hasil dari Tim Khusus bisa berupa berita acara } \\
\text { kesepakatan para pihak, maupun rekomendasi terhadap } \\
\text { permasalahan pertanahan. Dan terhadap hasilnya ada } \\
\text { yang bisa dilaksanakan eksekusinya dan ada pula yang } \\
\text { tidak dapat dilaksanakan. }\end{array}$ \\
\hline 2. & Kantah Kota Banjarmasin & $\begin{array}{l}\text { Hasil dari Tim Khusus bisa berupa berita acara } \\
\text { kesepakatan para pihak, maupun rekomendasi terhadap } \\
\text { permasalahan pertanahan. Dari hasil dapat dilaksanakan } \\
\text { eksekusinya dan ada pula yang tidak dapat dilaksanakan. }\end{array}$ \\
\hline 3. & Kantah Kota BanjarBaru & Tidak \\
\hline 4. & Kantah kab. Tanah Laut & - \\
\hline 5. & Kantah Kab. Barito Kuala & \\
\hline 6. & Kantah Kab. Banjar & \\
\hline
\end{tabular}

Sumber: Hasil Pengumpulan Data, 2013

\section{TABEL 4.21. PETA/DATA SEBARAN SENGKETA/KONFLIK}

\begin{tabular}{|l|l|l|}
\hline NO & \multicolumn{1}{|c|}{ WILAYAH PENELITIAN } & $\begin{array}{l}\text { EKSEKUSI SESUAI DENGAN BERITA ACARA HASIL } \\
\text { TIM PENYELESAIAN KASUS }\end{array}$ \\
\hline 1. & $\begin{array}{l}\text { Kanwil Provinsi } \\
\text { Kalimantan Selatan }\end{array}$ & $\begin{array}{l}\text { Ya, terdapat peta/data sebaran sengketa/konflik dan } \\
\text { data karakteristik mayoritas dengan tipologi sengketa } \\
\text { penguasaan pemilikan. }\end{array}$ \\
\hline 2. & Kantah Kota Banjarmasin & Tidak \\
\hline 3. & Kantah Kota BanjarBaru & Tidak ada \\
\hline 4. & Kantah kab. Tanah Laut & \\
\hline 5. & Kantah Kab. Barito Kuala & \\
\hline 6. & Kantah Kab. Banjar & \\
\hline
\end{tabular}

Sumber: Hasil Pengumpulan Data, 2013 


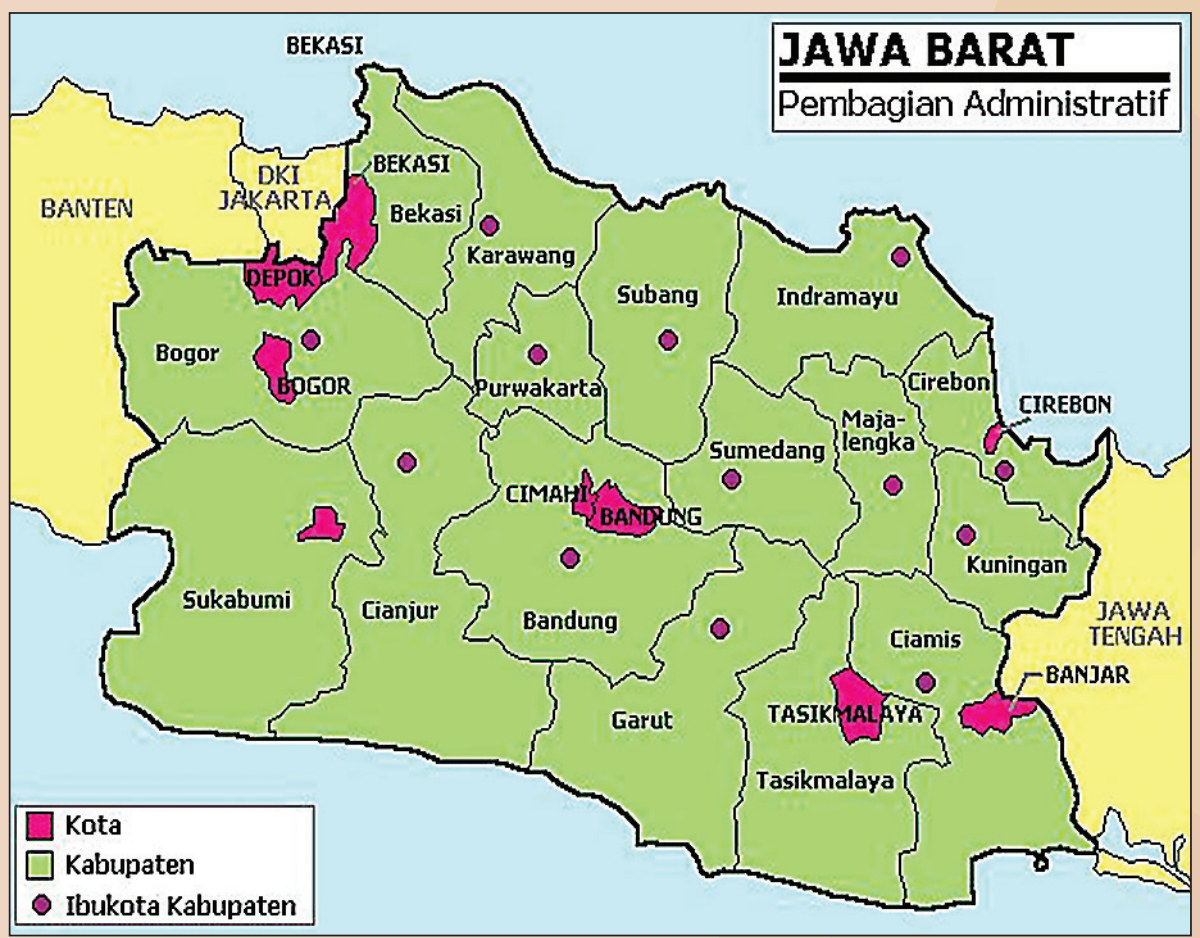

Gambar 4.4. Provinsi Jawa Barat

\section{PROVINSI JAWA BARAT}

\subsection{Karakteristik Wilayah}

Jawa Barat adalah salah satu provinsi di sebelah barat Pulau Jawa dengan ibu kotanya berada di Kota Bandung yang dulu dikenal sebagai Paris van java. Perkembangan Sejarah menunjukkan bahwa Provinsi Jawa Barat merupakan Provinsi yang pertama dibentuk di wilayah Indonesia (Staatblad Nomor: 378). Provinsi Jawa Barat dibentuk berdasarkan UU No.11 Tahun 1950, tentang Pembentukan Provinsi Jawa Barat.

Secara geografis, Provinsi Jawa Barat berbatasan dengan Laut Jawa di bagian Utara, Provinsi Jawa Tengah di bagian Timur, Samudera Hindia di bagian Selatan, serta Provinsi Banten di bagian Barat Laut. Provinsi Jawa Barat memiliki luas wilayah $35.222 .18 \mathrm{~km} 2$.
Provinsi Jawa Barat, sejak berdirinya sampai sekarang telah dipimpin oleh 11 orang Gubernur, yaitu: M Sutardjo Kartohadi (19451946), Mr.Datuk Djamin (1946), M.Sewaka (1946-1952), R.Muhamad sanusi Hardjadinata (1952-1956), R.Ipik Gandamana (1956-1960), H. Mashidu (1960-1970), Solihin GP (19701975), H.Aang Kunaefi (1975-11985), HR.Yogie SM (1985-1993), R.Nuriana (1993-2003) dan H.Danny Setiawan (2003 - 2008), Ahmad Heryawan dan Yusuf Macan Effendi (20082013)

Pemerintah Provinsi Jawa Barat, terdiri dari unsur Sekertariat Daerah (Setda) yang meliputi: Sekretaris daerah dan AssistenAssisten: Pemerintahan, Perekonomian, Adminsitrasi dan Kesejahteraan Sosial serta biro-biro yang seluruhnya 13 biro; 20 Dinas; 
16 Badan; 1 Kas Daerah, 1Kantor Perwakilan pemerintah Provinsi Jawa Barat, yang berkedudukan di Jakarta.

Organisasi Perangkat Daerah terdiri dari Dinas Kesehatan, Dinas Pendidikan, Dinas Sosial, Dinas Pertanian Tanaman Pangan, Dinas Peternakan, Dinas Periklanan, Dinas Kehutanan, Dinas Perkebunan,
Dinas Perhubungan, Dinas Tata Ruang dan Pemukiman, Dinas Bina Marga, Dinas Pengelolaan Sumber Daya Air, Dinas Pertambangan dan Energi, Dinas Koperasi dan Usaha Kecil Menengah, Dinas Kebudayaan dan Pariwisata Jawa barat, Dinas Pendapatan Daerah, Dinas Perindustrian dan Perdagangan, Dinas Nakertrans, Polisi Pamong Praja, Dinas Perindagro.

\section{TABEL 4.22. KABUPATEN DAN KOTA DI PROVINSI JAWA BARAT}

\begin{tabular}{|c|c|c|c|c|}
\hline NO. & KABUPATEN/KOTA & IBUKOTA & KECAMATAN & DESA/KEL \\
\hline 1 & Kabupaten Bandung & Soreang & 31 & 278 \\
\hline 2 & Kab. Bandung Barat & Ngamprah & 16 & 165 \\
\hline 3 & Kabupaten Bekasi & Cikarang & 23 & 187 \\
\hline 4 & Kabupaten Bogor & Cibinong & 40 & 426 \\
\hline 5 & Kabupaten Ciamis & Ciamis & 27 & 266 \\
\hline 6 & Kabupaten Cianjur & Cianjur & 32 & 348 \\
\hline 7 & Kabupaten Cirebon & Sumber & 40 & 412 \\
\hline 8 & Kabupaten Garut & Tarogong Kidul & 42 & 439 \\
\hline 9 & Kabupaten Indramayu & Indramayu & 31 & 317 \\
\hline 10 & Kabupaten Karawang & Karawang & 30 & 309 \\
\hline 11 & Kabupaten Kuningan & Kuningan & 32 & 376 \\
\hline 12 & Kabupaten Majalengka & Majalengka & 26 & 332 \\
\hline 13 & Kabupaten Pangandaran & Parigi & 10 & 92 \\
\hline 14 & Kabupaten Purwakarta & Purwakarta & 17 & 192 \\
\hline 15 & Kabupaten Subang & Subang & 30 & 253 \\
\hline 16 & Kabupaten Sukabumi & Pelabuhan Ratu & 47 & 367 \\
\hline 17 & Kabupaten Sumedang & Sumedang & 26 & 277 \\
\hline 18 & Kabupaten Tasikmalaya & Singaparna & 39 & 348 \\
\hline 19 & Kota Bandung & - & 30 & 151 \\
\hline 20 & Kota Banjar & - & 4 & 25 \\
\hline 21 & Kota Bekasi & - & 12 & 56 \\
\hline 22 & Kota Bogor & - & 6 & 68 \\
\hline 23 & Kota Cimahi & - & 3 & 15 \\
\hline 24 & Kota Cirebon & - & 5 & 21 \\
\hline 25 & Kota Depok & - & 11 & 63 \\
\hline 26 & Kota Sukabumi & - & 7 & 33 \\
\hline 27 & Kota Tasikmalaya & - & 10 & 60 \\
\hline
\end{tabular}




\subsection{Pemilikan/Penguasaan Tanah}

Berdasarkan data sejarah (Staatsblad Nomor 378 tanggal 14 Agustus 1925), Provinsi Jawa Barat Tingkat I merupakan Provinsi yang pertama dibentuk di wilayah Hindia Belanda. Pembentukan Provinsi Jawa Barat tersebut, nama resminya West Java Provinsi bagi kalangan Belanda atau formal pemerintah kolonial Hindia Belanda dan Pasundan bagi kalangan orang bumi putera, dimaksudkan untuk melaksanakan janji pemerintah kerajaan Belanda tahun 1901 yang memberikan hak otonomi kepada pemerintah Indonesia. Tahun-tahun berikutnya baru dibentuk Provinsi Jawa Timur (Oost Java Provinci).

Meskipun demikian, hal itu bukan berarti bahwa pemerintahan di daerah Jawa Barat baru di mulai sejak tahun 1925 dan sebelumnya belum pernah ada pemerintahan. Kenyataan lain menunjukan, jauh sebelum tahun tersebut di daerah Jawa Barat telah tumbuh dan berkembang suatu pemerintahan tertentu walaupun bentuk, sistem, dan strukturnya berlainan dengan tingkat Provinsi. Paling tidak sejak abad ke-5 di Jawa Barat telah tumbuh suatu pemerintahan yang teratur, yaitu berbentuk kerajaan. Kerajaan dimaksud bernama Tarumanagara dan salah seorang rajanya adalah Purnawarman. sudah barang tentu bentuk pemerintahan demikian tidak terwujud sekali jadi, melainkan melalui proses yang tidak sebentar.

Menurut sumber, pemerintahan berbentuk kerajaan muncul pada abad ke-2 Masehi, yaitu pemerintahan Kerajaan Salakanagara dengan ibukotanya Rajatapura dan pendirinya Dawawarman. Dari data sejarah tersebut maka pemerintah menerbitkan Undang-undang Tahun 1950 Nomor 11 meliputi: Karesidenan Banten, Jakarta, Bogor, Priangan dan Cirebon. Meskipun demikian, hal itu bukan berarti bahwa pemerintahan di daerah Jawa Barat baru dimulai sejak tahun 1925 dan sebelumnya belum pernah ada pemerintahan.

Sejak masa kerajaan Tarumanagara hingga lahirnya Provinsi Jawa Barat, di daerah Jawa Barat tiada henti-hentinya berlangsung suatu pemerintahan yang teratur namun bentuk, struktur dan sistem pemerintahan serta pusat pemerintahan dan pemegang kekuasaan mengalami perubahan dan pergantian juga perkembangan.

Adapun sistem dan struktur pemerintahan kabupaten-kabupaten di priangan (sejak abad ke-17) serta di banten dan cirebon (sejak abad ke-19) dipengaruhi pula oleh konsep pemerintahan Jawa dari zaman Mataram dan konsep pemerintahan Barat yang dibawa oleh orang Belanda dan orang Inggris.

Jika bentuk pemerintahan di Jawa Barat sejak zaman Kerajaan Tarumanagara hingga Kerajaan Sunda umumnya cenderung berpusat pada satu pemerintahan pusat, tetapi pada masa Kesultanan Cirebon, Kesultanan Banten, hingga masa kompeni terbagi atas lebih dari satu pusat pemerintahan.

Pada masa pemerintahan kolonial Hindia Belanda terdapat dualisme sistem pemerintahan di daerah Jawa Barat, yaitu antara sistem pemerintahan kolonial yang berdasarkan konsep Barat yang berlaku untuk orang-orang Eropa dan hubungan mereka dengan penguasa-penguasa pribumi (bupati) dengan sistem pemerintahan tradisional yang berdasarkan konsep yang 
tumbuh dalam masyarakat pribumi sendiri serta berlaku dari Kabupaten ke bawah.

Lokasi pusat pemerintahan mengalami beberapa kali perpindahan, sesuai dengan berbagai aspek kehidupan masyarakat yang mempengaruhinya dan terjadinya peristiwa dan timbulnya suasana pemerintahan. Sedangkan pemegang kekuasaan bergantiganti secara individual dan dinasti seiring dengan masalah usia manusia (pergantian generasi) dan perubahan politik, ekonomi, sosial, agama, dan sebagainya.

Gubernur Jendral H. W. Deandels merupakan penguasa kolonial pertama yang mengeluarkan peraturan tertulis mengenai Pemerintahan di Jawa Barat (1809), sedangkan sebelumnya pemerintahan kolonial diatur hanya berdasarkan kebijakankebijakan para pejabat kolonial setempat. Baru pada tahun 1854 dikeluarkan oleh pemerintah kolonial Hindia Belanda sebuah undang-udang yang berlaku umum yang dinamai Regeringsregrelement (RR).

Pada tahun 1906 dibentuk Gementee (sekarang kotamadya) di enam buah kota di daerah Jawa Barat (Batavia, Meester Cornelis, Buitenzorg, Sukabumi, Bandung, dan Cherebon) yang merupakan pemerintah daerah otonom pertama di Indonesia, walaupun fungsinya baru kepentingan orangorang Eropa setempat.

Sekitar 19 tahun kemudian barulah dibentuk daerah otonom yang lebih luas yang meliputi seluruh daerah Jawa Barat (dulu Jakarta dan Jatinegara masuk dalam wilayah pemerintahan Jawa Barat) dalam bentuk Provinsi. Pada masa itu pusat pemerintahan Provinsi Jawa Barat berada di Jakarta dan kepala daerahnya disebut gubernur yang selalu dipegang oleh orang Belanda.
Pada masa itu pula lahir Lembaga Legeslatif secara formal dalam struktur pemerintah daerah yang sekarang dikenal dengan nama Dewan Perwakilan Rakyat Daerah (DPRD). Lembaga Legeslatif daerah dimaksud adalah Gemeenteraad bagi tingkat Gemeente, Regentschapsraad bagi tingkat Kabupaten, dan Provincieraad bagi tingkat Provinsi.

Anggota legestalif daerah Jawa Barat (seperti juga di daerah-daerah lainnya dan di pusat atau Volksraad) di domonasi oleh orang Belanda, baru kemudian dalam jumlah kecil terapat anggota dari kalangan orang pribumi (Indonesia) dan orang Timur Asing (Cina, India, dan Arab).

Ketua Lembaga Legislatif tersebut ditempati oleh kepala daerah yakni Burgemeester (Walikota) pada tingkat Gemeente, Bupati pada tingkat Kabupaten, Gubernur pada tingkat Provinsi. sebagian anggota Lembaga Legeslatif daerah itu dipilih oleh rakyat tertentu (tidak semua rakyat dewasa mempunyai hak pilih), sebagian lagi diangkat oleh pemerintah daerah setempat.

Pada masa pendudukan militer Jepang (1942-1945) pemerintah daerah tingkat Provinsi ditiadakan. Yang ada hanyalah pemerintah daerah tingkat karesidenan (Shu) kebawah, yaitu Kotamadya (Si), Kabupaten (Ken), Kewadanan (Gun), Kecamatan (Son), dan Desa $(K u)$. Kiranya hal itu dimungkinkan, karena terlebih dahulu wilayah Indonesia dibagi atas tiga daerah pemerintahan yang masing-masing dipimpin oleh suatu kesatuan militer.

Sesudah Indonesia merdeka (1945) pemerintah daerah tingkat provinsi diadakan lagi. Keputusan ini ditetapkan dalam sidang Panitia Persiapan Kemerdekaan Indonesia 
(PPKI) pada tanggal 19 Agustus 1945. Menurut keputusan tersebut wilayah Republik Indonesia dibagi atas 8 daerah admnistrasi peemrintahan berupa provinsi yang salah satu diantaranya ialah Provinsi Jawa Barat.

Ibukota Provinsi Jawa Barat pada mulanya tetap di Jakarta, namun karena kemudian di Jakarta terjadi kekacauan sesudah kedatangan tentara Belanda di bawah NICA (Netherland Indie Civil Administration), pimpinan dan pemerintahan Republik Indonesia meninggalkan kota tersebut, maka ibukota provinsi Jawa Barat pun di pindahkan ke Kota Bandung (awal tahun 1946). Sejak waktu itu hingga sekarang ibukota Provinsi Jawa Barat tetap berkedudukan di Kota Bandung.

Selama masa Republik Indonesia yang telah berjalan lebih dari 47 tahun telah banyak terjadi peristiwa dan perubahan suasana di dalam pemerintahan daerah, termasuk pemerintahan di daerah Jawa Barat. Pada tahun 1956 daerah ibukota RI Jakarta dipisahkan dari daerah administrasi pemerintahan Provinsi Jawa Barat, karena dibentuk Daerah Istimewa Jakarta dan kemudian menjadi Daerah Khusus Ibukota Jakarta Raya yang kedudukannya setingkat provinsi.

Beberapa undang-undang yang mengatur pemerintahan daerah, termasuk pemerintahan desa, telah dilahirkan untuk mengembangkan dan meningkatkan pemerintahan daerah itu. Beberapa ujian berat telah dialami pula oleh pemerintah Daerah Jawa Barat beserta warganya. Dewasa ini, sejak lahirnya Orde Baru (1966), Pemerintahan Daerah Jawa Barat beserta seluruh warganya tengah berupaya keras melaksanakan pembangunan dalam segala bidang kehidupan rakyat, dengan titik berat pada bidang ekonomi guna meningkatkan kesejahteraan dan keadilan sosial bagi seluruh rakyat Jawa Barat dan seluruh rakyat Indonesia pada umumnya.

Kasus yang mencuat di daerah Jawa barat pada tahun 1991-2000 adalah kasus Cimacan yang merupakan sengketa antara warga dengan PT Bandung Asri Mulya dan Pemerintah Daerah Cianjur. Petani melakukan pencangkulan lapangan golf sebagai bentuk protes petani atas pemberian ganti rugi yang tidak memuaskan. Kasus rumpin juga menjadi perhatian berkaitan aksi protes masyarakat kampung Cibitung desa Sukamulya kecamatan Rumpin Kabupaten Bogor yang menimbulkan korban, konflik terjadi antara TNI-AU dengan masyarakat yang menolak pembangunan Water Training karena tanah tersebut dianggap masih milik mereka.

\subsection{Profil Kasus Pertanahan}

Tabel 4.23 menunjukkan bahwa frekwensi masalah penguasaan dan pemilikan tanah yang tertinggi di Provinsi dan kota/ kabupaten sampel. Yang kedua berbedabeda di tiap daerah, untuk Kanwil dan Kota Cimahi, masalah yang kedua adalah masalah prosedur penetapan hak dan pendaftaran tanah, untuk Kota Bandung, kab. Bandung Barat dan Kota Depok masalah batas/letak bidang tanah.

Tabel 4,24 menunjukkan bahwa pembagian tipologi berdasarkan hasil RDP di atas belum dilakukan oleh Kanwil dan Kantah Kota Bandung, serta Kab. Bandung Barat.

Frekwensi kasus pertanahan sebagaimana tabel 4.25 menunjukkan hanya ada kasus sengketa di Kota Depok dan Bandung Barat dan hampir semuanya dilakukan upaya mediasi. 
TABEL 4.23. TIPOLOGI MASALAH PERTANAHAN

\begin{tabular}{|c|c|c|c|c|c|c|}
\hline NO. & KABUPATEN/KOTA & KANWIL & $\begin{array}{c}\text { KOTA } \\
\text { BANDUNG }\end{array}$ & $\begin{array}{l}\text { KOTA } \\
\text { CIMAHI }\end{array}$ & $\begin{array}{l}\text { KOTA } \\
\text { DEPOK }\end{array}$ & $\begin{array}{c}\text { KAB. } \\
\text { BANDUNG } \\
\text { BARAT }\end{array}$ \\
\hline 1. & $\begin{array}{l}\text { Masalah Penguasaan dan } \\
\text { Pemilikan Tanah }\end{array}$ & $82,43 \%$ & $67 \%$ & $55 \%$ & $80 \%$ & $61,6 \%$ \\
\hline 2. & Masalah batas/letak bid. tanah & $1,58 \%$ & $31 \%$ & $10 \%$ & $20 \%$ & $23 \%$ \\
\hline 3. & $\begin{array}{l}\text { Masalah prosedur Penetapan } \\
\text { Hak \& Pendaftaran Tanah }\end{array}$ & $11,37 \%$ & - & $20 \%$ & - & $15,4 \%$ \\
\hline 4. & Masalah pelaksanaan & $1,91 \%$ & - & $20 \%$ & - & - \\
\hline 5. & $\begin{array}{l}\text { putusan pengadilan } \\
\text { Masalah tanah ulayat }\end{array}$ & $0,23 \%$ & - & - & - & - \\
\hline 6. & $\begin{array}{l}\text { Masalah tanah obyek } \\
\text { Landreform }\end{array}$ & $1,35 \%$ & - & - & - & - \\
\hline 7. & $\begin{array}{l}\text { Masalah ganti rugi tanah } \\
\text { ex. Partikelir }\end{array}$ & $0,25 \%$ & - & - & - & - \\
\hline 8. & Masalah pengadaan tanah & $0,56 \%$ & - & $15 \%$ & - & - \\
\hline
\end{tabular}

Sumber: Hasil Pengumpulan Data, 2013

\section{TABEL 4.24. TIPOLOGI KASUS PERTANAHAN HASIL RDP}

\begin{tabular}{|c|l|c|c|c|c|c|}
\hline NO. & \multicolumn{1}{|c|}{ KABUPATEN/KOTA } & KANWIL & $\begin{array}{c}\text { KOTA } \\
\text { BANDUNG }\end{array}$ & $\begin{array}{c}\text { KOTA } \\
\text { CIMAHI }\end{array}$ & $\begin{array}{c}\text { KOTA } \\
\text { DEPOK }\end{array}$ & $\begin{array}{c}\text { KAB. } \\
\text { BANUNG } \\
\text { BARAT }\end{array}$ \\
\hline 1. & Masyarakat dengan swasta & - & - & $20 \%$ & $100 \%$ & - \\
\hline 2. & TNI dengan POLRI & - & - & $15 \%$ & - & - \\
\hline 3. & Masyarakat Adat & - & - & $40 \%$ & - & - \\
\hline 4. & kehutanan & - & - & - & - & - \\
\hline 5. & ESDM/Pertambangan & - & - & - & - & - \\
\hline 6. & BUMN & - & - & - & - & - \\
\hline 7. & PU/Departemen lainnya & - & - & $25 \%$ & - & - \\
\hline
\end{tabular}

Sumber: Hasil Pengumpulan Data, 2013

\section{TABEL 4.25. FREKWENSI KASUS PERTANAHAN DAN PENYELESAIANNYA}

\begin{tabular}{|c|l|c|c|c|c|c|}
\hline NO. & WILAYAH PENELITIAN & SENGKETA & KONFLIK & MEDIASI & LITIGASI & $\begin{array}{c}\text { EXECUTOIR } \\
\text { BESLAAG }\end{array}$ \\
\hline 1. & Kanwil & - & - & - & - & - \\
\hline 2. & Kota Bandung & - & - & - & - & - \\
\hline 3. & Kota Cimahi & - & - & - & - & - \\
\hline 4. & Kota Depok & 8 & - & 8 & 32 & - \\
\hline 5. & Kab Bandung Barat & 13 & - & 12 & 1 & 1 \\
\hline
\end{tabular}

Sumber: Hasil Pengumpulan Data, 2013 


\section{TABEL 4.26. ASPEK YANG DITELITI DALAM PENELITIAN MENGENAI AKAR MASALAH}

\begin{tabular}{|c|c|c|}
\hline NO & WILAYAH PENELITIAN & ASPEK YANG DITELITI \\
\hline 1. & Kanwil & $\begin{array}{l}\text { Diteliti juga aspek sosiologis dan lainnya tidak hanya } \\
\text { aspek yuridisnya }\end{array}$ \\
\hline 2. & Kota Bandung & $\begin{array}{l}\text { Diteliti juga aspek sosiologis dan lainnya tidak hanya } \\
\text { aspek yuridisnya }\end{array}$ \\
\hline 3. & Kota Cimahi & Tidak menjawab \\
\hline 4. & Kota Depok & $\begin{array}{l}\text { Ya, kami berupaya menangani/menyelesaikan setiap } \\
\text { kasus dengan memahami semua sepek sosiologi, karena } \\
\text { kondisi masyarakat yang kami perhatikan merupakan } \\
\text { daya juang selesainya kasus di kota Depok dengan cara } \\
\text { mufakat }\end{array}$ \\
\hline 5. & Kab Bandung Barat & $\begin{array}{l}\text { Diteliti karena pada hakikatnya masalah pertanahan terkait } \\
\text { dengan perlakuan manusia sehingga pada kasus yang } \\
\text { rumit dapat mengandung berbagai macam aspek, maka } \\
\text { penanganannya tidak cukup hanya secara hukum saja }\end{array}$ \\
\hline
\end{tabular}

Sumber: Hasil Pengumpulan Data, 2013

\section{TABEL 4.27. TIM KHUSUS PENYELESAIAN KASUS PERTANAHAN}

\begin{tabular}{|c|c|c|}
\hline NO & WILAYAH PENELITIAN & $\begin{array}{l}\text { APAKAH ADA TIM KHUSUS PENYELESAIAN } \\
\text { KASUS PERTANAHAN DI TINGKAT PROVINSI, DAN } \\
\text { KABUPATEN/KOTA }\end{array}$ \\
\hline 1. & Kanwil & $\begin{array}{l}\text { Tidak ada tim khusus (ada tim ad hoc seperti kasus HGU } \\
\text { PT Rajawali, PT Indonesia Power dll) }\end{array}$ \\
\hline 2. & Kota Bandung & Tidak ada \\
\hline 3. & Kota Cimahi & $\begin{array}{l}\text { Tidak ada tim khusus (ada Tim Fasilitasi dan Mediasi } \\
\text { Penyelesaian Permasalahan dibuat berdasarkan SK } \\
\text { Walikota Cimahi No. 593.05/Kep.54-Pem/2013) }\end{array}$ \\
\hline 4. & Kota Depok & $\begin{array}{l}\text { Khusus di kota Depok penanganan skasus ditangani } \\
\text { di seksi sengketa konflik dan perkara yang selanjutnya } \\
\text { dalam tiap penanganan kasus memberikan surat tugas } \\
\text { kepada tim }\end{array}$ \\
\hline 5. & Kab Bandung Barat & Ada \\
\hline
\end{tabular}

Sumber: Hasil Pengumpulan Data, 2013 
Berdasarkan table 4.26 diperoleh gambaran bahwa dalam penelitian akar masalah tidak hanya aspek yuridis saja yang diteliti tetapi juga aspek sosiologi terkait dengan kondisi masyarakat dan perilaku manusia.

Table 4.27 menunjukkan bahwa baik di kanwil Provinsi jawa Barat maupun di Kota Bandung, Cimahi dan Depok tidak ada tim khusus penyelesaian kasus pertanahan, yang ada hanya di Kab. Bandung Barat.
Dari tabel 4.28 di bawah menunjukkan bahwa beberapa responden belum dapat melakukan eksekusi berita acara kesepakatan karena beberapa hal, antara lain obyeknya dikuasai pihak lain, para pihak ingkar janji terhadap kesepakatan dan kurangnya alat bukti yang valid.

Berdasarkan tabel 4.29, menunjukkan tidak tersedianya peta konflik di daerah sampel kecuali Kota Depok ada peta sebaran tapi bersifat kasuistis dan kab. Bandung Barat ada peta konflik namun tidak up to date.

\section{TABEL 4.28. EKSEKUSI BERITAACARA TIM PENYELESAIAN KASUS}

\begin{tabular}{|c|c|c|}
\hline NO & WILAYAH PENELITIAN & $\begin{array}{c}\text { EKSEKUSI SESUAI DENGAN BERITA ACARA HASIL } \\
\text { TIM PENYELESAIAN KASUS }\end{array}$ \\
\hline 1. & Kanwil & Belum bisa (masih dalam proses penelitian) \\
\hline 2. & Kota Bandung & Tidak menjawab \\
\hline 3. & Kota Cimahi & Tidak menjawab \\
\hline 4. & Kota Depok & $\begin{array}{l}\text { Output dari mediasi yang kami laksanakan adalah berupa } \\
\text { berita acara, yang selanjutnya diteruskan dengan nota } \\
\text { dinas seksi SKP terhadap kepala kantor/seksi, hal ini } \\
\text { sudah merupakan ketentuan adapun untuk para pihak } \\
\text { dikeluarkan surat hasil tindak lanjut mediasi }\end{array}$ \\
\hline 5. & Kab Bandung Barat & $\begin{array}{l}\text { Sampai saat ini belum dapat dieksekusi, karena beberapa } \\
\text { hal, antara lain: obyeknya dikuasai pihak lain, belum ada } \\
\text { kesepakatan para pihak yang bersangkutan, kurangnya } \\
\text { alat bukti yang valid }\end{array}$ \\
\hline
\end{tabular}

Sumber: Hasil Pengumpulan Data, 2013

\section{TABEL 4.29. PETA/DATA SEBARAN SENGKETA/KONFLIK}

\begin{tabular}{|l|l|l|}
\hline NO & \multicolumn{1}{|c|}{ WILAYAH PENELITIAN } & \multicolumn{1}{|c|}{ PETA/DATA SEBARAN SENGKETA/KONFLIK } \\
\hline 1. & Kanwil & Tidak ada \\
\hline 2. & Kota Bandung & Ada \\
\hline 3. & Kota Cimahi & Tidak menjawab \\
\hline 4. & Kota Depok & $\begin{array}{l}\text { Kami mempunyai peta sebaran masalah khusus terhadap } \\
\text { kasus tertentu }\end{array}$ \\
\hline 5. & Kab Bandung Barat & $\begin{array}{l}\text { Ada, namun tidak sesuai dengan kondisi saat ini (tidak up } \\
\text { to date) }\end{array}$ \\
\hline
\end{tabular}

Sumber: Hasil Pengumpulan Data, 2013 


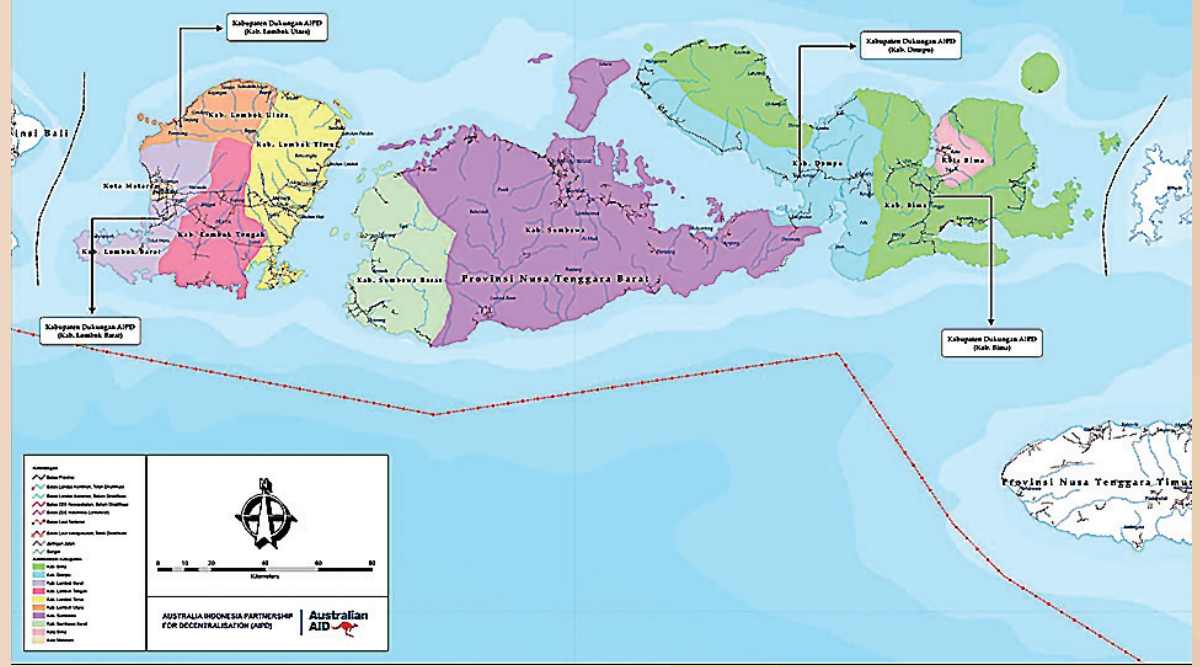

Gambar 4.5. Peta Provinsi Nusa Tenggara Barat

\section{PROVINSI NUSA TENGGARA BARAT}

\subsection{Karakteristik Wilayah}

Nusa Tenggara Barat adalah sebuah provinsi di Indonesia yang sesuai dengan namanya, provinsi ini meliputi bagian barat Kepulauan Nusa Tenggara. Dua pulau terbesar di provinsi ini adalah Pulau Lombok yang terletak di bagian barat dan Pulau Sumbawa yang terletak di bagian timur. Ibu kota Provinsi Nusa Tenggara Barat adalah Kota Mataram yang berada di Pulau Lombok.

Letak dan Keadaan Alam Nusa Tenggara Barat yang terdiri dari Pulau Lombok dan Pulau Sumbawa, memiliki luas wilayah 20.153,15 km2.Terletak antara $115^{\circ} 46^{\prime}-119^{\circ} 5^{\prime}$ Bujur Timur dan $8^{\circ} 10^{\prime}-9^{\circ} \mathrm{g} 5^{\prime}$ Lintang Selatan. Selong merupakan kota yang mempunyai ketinggian paling tinggi, yaitu $148 \mathrm{~m}$ dari permukaan laut sementara Raba terendah dengan $13 \mathrm{~m}$ dari permukaan laut. Dari tujuh gunung yang ada di Pulau Lombok, Gunung Rinjani merupakan tertinggi dengan ketinggian $3.775 \mathrm{~m}$, sedangkan Gunung Tambora merupakan gunung tertinggi di Sumbawa dengan ketinggian $2.851 \mathrm{~m}$.

Iklim berdasarkan data statistik lembaga meteorologi, temperatur maksimum pada tahun 2001 berkisar antara 30,9 $-32,1^{\circ} \mathrm{C}$, dan temperatur minimum berkisar antara $20,6^{\circ}-24,5^{\circ} \mathrm{C}$. Temperatur tertinggi terjadi pada bulan September dan terendah ada bulan Nopember. Sebagai daerah tropis, NTB mempunyai rata-rata kelembaban yang relatif tinggi, yaitu antara 48 - 95\%

Mayoritas penduduk Pulau Lombok berasal dari suku Sasak, sementara suku Bima dan Sumbawa merupakan kelompok etnis terbesar yang mendiami Pulau Sumbawa. Mayoritas penduduk Nusa Tenggara Barat beragama Islam (96\%). 
TABEL 4.30. KABUPATEN DAN KOTA DI PROVINSI NTB

\begin{tabular}{|c|l|l|c|c|}
\hline NO. & \multicolumn{1}{|c|}{ KABUPATEN/KOTA } & \multicolumn{1}{|c|}{ IBUKOTA } & KECAMATAN & DESAKEL \\
\hline 1 & Kabupaten Bima & Raba & 19 & 150 \\
\hline 2 & Kabupaten Dompu & Dompu & 8 & 71 \\
\hline 3 & Kabupaten Lombok Barat & Gerung & 10 & 88 \\
\hline 4 & Kabupaten Lombok Tengah & Praya & 12 & 107 \\
\hline 5 & Kabupaten Lombok Timur & Selong & 20 & 109 \\
\hline 6 & Kabupaten Lombok Utara & Tanjung & 5 & 33 \\
\hline 7 & Kabupaten Sumbawa & Sumbawa Besar & 24 & 152 \\
\hline 8 & Kabupaten Sumbawa Barat & Taliwang & 8 & 54 \\
\hline 9 & Kota Bima & - & 5 & 38 \\
\hline 10 & Kota Mataram & - & 3 & 50 \\
\hline
\end{tabular}

Sumber : Wikipedia, 2013

Keberadaan status provinsi, bagi NTB tidak datang dengan sendirinya. Perjuangan menuntut terbentuknya Provinsi NTB berlangsung dalam rentang waktu yang cukup lama. Provinsi NTB, sebelumnya sempat menjadi bagian dari Negara Indonesia Timur dalam konsepsi Negara Republik Indonesia Serikat, dan menjadi bagian dari Provinsi Sunda kecil setelah pengakuan kedaulatan Republik Indonesia.

Seiring dinamika zaman dan setelah mengalami beberapa kali proses perubahan sistem ketatanegaraan pasca diproklamasikannya Kemerdekaan Republik Indonesia, barulah terbentuk Provinsi NTB. NTB, secara resmi mendapatkan status sebagai provinsi sebagaimana adanya sekarang, sejaktahun 1958 , berawal dari ditetapkannya Undang-undang Nomor 64 Tahun 1958 Tanggal 14 Agustus 1958 tentang Pembentukan Daerah-daerah Swatantra Tingkat I Bali, NTB dan NTT, dan yang dipercayakan menja di Gubernur pertamanya adalah AR. Moh. Ruslan Djakraningrat.

Walaupun secara yuridis formal Daerah Tingkat I NTB yang meliputi 6 Daerah Tingkat II dibentuk pada tanggal 14 Agustus 1958, namun penyelenggaraan pemerintahan berjalan berdasarkan Undang- undang Negara Indonesia Timur Nomor 44 Tahun 1950, dan Undang-undang Nomor 1 Tahun 1957 tentang Pokok-pokok Pemerintahan Daerah. Keadaan yang tumpang tindih ini berlangsung hingga tanggal 17 Desember 1958, ketika Pemerintah Daerah Lombok dan Sumbawa di likuidasi. Hari likuidasi inilah yang menandai resmi terbentuknya Provinsi NTB. Zaman terus berganti, konsolidasi kekuasaan dan pemerintahanpun terus terjadi.

Pada tahun 1968 dalam situasi yang masih belum menggembirakan sebagai akibat berbagai krisis nasional yang membias ke daerah, gubernur pertama AR. Moh. Ruslan Tjakraningrat digantikan oleh HR.Wasita Kusuma. Dengan mulai bergulirnya program pembangunan lima tahun tahap pertama (pelita I) langkah perbaikan ekonomi, sosial, politik mulai terjadi. Pada tahun 1978 H.R.Wasita Kusuma digantikan H.Gatot Soeherman sebagai Gubernur Provinsi NTB yang ketiga. Dalam masa kepemimpinannya, usaha-usaha pembangunan kian dimantapkan dan Provinsi NTB yang dikenal sebagai daerah minus, berubah menjadi daerah swasembada. 
Pada tahun 1988 Drs. H. Warsito, SH terpilih memimpin NTB menggantikan H. Gatot Soeherman. Drs.H.Warsito, SH mengendalikan tampuk pemerintahan di Provinsi NTB untuk masa dua periode, sebelum digantikan Drs. $\mathrm{H}$. Harun Al Rasyid, M.Si pada tanggal 31 Agustus 1998.

Drs. H. Harun Al Rasyid M.Si berjuang membangun NTB dengan berupaya meningkatkan kualitas sumber daya manusia melalui Program Gema Prima. Tahun 2003 hingga 1 september 2008 Drs. H. Lalu Serinatadan wakil Gubernur Drs.H.B. Thamrin Rayes memimpin NTB. Pada masa ini berbagai macam upaya dilakukan dalam membangun NTB dan mengejar ketertinggalan diberbagai bidang dan sektor. Di zaman ini,sejumlah program diluncurkan, seperti Gerbang E-Mas dengan Program Emas Bangun Desa. Selain itu, pada masa ini pembangunan Bandara Internasional Lombok di Lombok Tengah mulai terealisasi dan ditargetkan rampung pertengahan 2009.

Dalam usianya yang ke-52 Provinsi NTB kini dipimpin oleh salah satu putra terbaiknya yaitu Gubernur Dr. KH. M. Zainul Majdi dan Wakil Gubernur Ir. H. Badrul Munir, MM. Pada tahun 2010 ini, kedua pasangan pemimpin menggenapkan dua tahun pemerintahannya di ProvinsiNTB untuk mengemban amanah dan harapan masyarakat Nusa Tenggara Barat dalam mencapai kesejahteraan dan pembangunan daerah menuju NTB yang Beriman dan Berdaya Saing.

\subsection{Pemilikan/Penguasaan Tanah Tanah untuk Pariwisata}

Pada saat pembangunan kepariwisataan NTB digalakkan, investor mulai berduyunduyun masuk ke provinsi ini, bersamaan dengan itu pengalihan tanah dari rakyat ke tangan pemilik modal terjadi secara besarbesaran.

Untuk melancarkan pembangunan kepariwisataan, seperangkat peraturan pun dikeluarkan, seperti SK Gub no. 113/1984 tentang penunjukan lokasi dan pengaturan penggunaan tanah untuk pengembangan pariwisata di propinsi NTB; SK Gub no. 20/1989 tentang pedoman pembangunan kawasan wisata di daerah NTB serta perda NTB No.91/1989 tentang pembangunan kawasan pariwisata di daerah NTB.

Dari peraturan-peraturan tersebut hampir semua daerah pinggiran pantai sebelah Barat, Selatan dan Timur Pulau Lombok merupakan kawasan wisata. Padahal, tanah-tanah di daerah pinggiran pantai sebagian besar dimiliki oleh masyarakat (petani dan nelayan) tanpa surat (sertipikat). Hal ini membuat ramainya kiprah spekulan tanah.

Dari segi pengembangannya kepariwisataan NTB memiliki beberapa ciri yang dapat dikenal seperti bersifat bertumpu pada kekuatan modal, sehingga investor bermodal kecil tidak mendapat tempat karena dianggap tidak mampu memacu pertumbuhan yang diharapkan.

Pembangunan kepariwisataan merupakan kesempatan besar untuk menggaet investasi masuk ke NTB, pemda bahkan mengeluarkan Perda No. 7/1990 tentang Usaha kawasan Pariwisata yang member peluang kepada para pengusaha untuk mengelola lahan sekurang-kurangnya 50ha untuk membangun usaha pariwisata meliputi pembangunan hotel, resort, restaurant, tempat rekreasi, hiburan umum dan usaha pariwisata lainnya. Berdasarkan perda ini, LTDC (Lombok Tourism Development Corporation) mendapat ijin 
menguasai kawasan pariwisata atas lahan seluas 1.250 ha. sebagai konsekuensinya LTDC memiliki hak untuk mengatur pengelolaan pariwisata di kawasan tersebut sehingga rakyat yang memiliki tanah di daerah tersebut (daerah Kuta) dan memiliki penginapan harus minggir.

Perda No 7/1990 membuat pengelolaan kepariwisataan oleh rakyat/modal kecil tidak memiliki peluan karena memberikan hak yang besar kepada pemerintah daerah untuk melakukan pengaturan penggunaan kepariwisataan, sehingga mau tidak mau tanah yang dimiliki rakyat pada daerah yang telah ditetapkan menjadi daerah pariwisata harus dijual/dibebaskan. Dalam kondisi demikian ada kecenderungan informasi mengenai pembangunan kepariwisataan tertutup. Akibatnya rakyat yang tidak tahu menahu mengenai tanah yang dimilikinya merupakan daerah/calon kawasan wisata sering dibodohi oleh calo untuk melepaskan tanahnya dengan harga murah.

Kasus-kasus pertanahan di NTB sebagaimana dijelaskan di atas mengurangi fungsi sosial tanah karena pemerintah daerah melalui peraturan daerahnya tampaknya lebih mengutamakan fungsi ekonomi tanah. Dari berbagai kasus yang berlangsung, permasalahan tanah di NTB diwarnai oleh beberapa hal yakni: praktek jual-beli, sewa gadai tanah, pembebasan tanah, ketidak jelasan peruntukan dan tata ruang, sengketa pemilikan lahan serta sengketa pemanfaatan sumber daya alam.

\section{Tanah Pecatu Perangkat Desa}

Di Lombok terdapat tanah-tanah milik persekutuan yang dalam perkembangannya didelegasikan kepada perorangan, dengan maksud dan kepentingan tertentu, misalnya dberikan kepada pemangku adat. Jabatan pemangku adat dahulu memang diberikan kepada suatu keluarga yang dipercaya merupakan orang-orang terpilih yang memiliki karakter seperti pahlawan dan dianggap bijaksana/sakti, ini berkaitan dengan kepentingan masyarakat untuk mendapatkan perlindungan dan pengayoman dari sang pemangku adat.

Pada masa sekarang, dengan adanya struktur pemerintahan Negara Republik Indonesia sampai pada struktur terbawah, memunculkan jabatan kepala desa yang dipilih dan bekerja untuk kepentingan masyarakat didaerahnya yang bisa disamakan dengan pemangku adat.

Kesamaan persepsi ini melahirkan pemandatan terhadap penguasaan tanah adat untuk dimiliki dan dikelola, namun dengan pembatasan masa kerja seseorang sebagai kepala desa.

Tanah dengan hak demikian dikenal dengan nama Tanah Pecatu di Lombok. Terdapat dua macam tanah pecatu, tanah pecatu milik masyarakat adat dan tanah pecatu milik pemerintah daerah. Tanah pecatu yang merupakan milik pemerintah pengelolaannya dilakukan oleh pemerintah daerah, tanah tersebut merupakan milik tuan-tuan tanah yang disumbangkan untuk kepentingan masyarakat desa sekitar, namun sumbangan ini diberikan kepada pemerintah daerah untuk dikoordinasikan. Dalam kamus sasak Indonesia, tanah pecatu atau meder adalah sawah yang diberikan oleh pemerintah daerah kepada kepala desa selama menjabat sebagai pengganti gaji. Tanah seperti ini di dalam masyarakat Jawa dikenal dengan nama tanah bengkok. Tanah pecatu di Lombok mirip namun tidak sama dengan tanah bengkok di Jawa. Hak yang ada disini adalah hak menikmati, artinya perangkat desa tersebut 
hanya berhak menikmati hasil dari tanah pecatu tersebut selama menjadi perangkat desa, apabila sudah selesai tugasnya maka kembali kepada Negara dan akan dinikmati oleh penggantinya, jadi tidak boleh dijual oleh perangkat desa.

Kepala desa mendapatkan hak pengelolaan atas tanah pecatu berdasarkan jabatan yang dimiliki, dalam melaksanakan haknya untuk mengelola tanah pecatu biasanya kepala desa menyewakan kepada pihak lain. Permasalahan yang timbul dengan praktik demikian misalnya ketika kepala desa yang bersangkutan meninggal dunia saat tanah masih disewakan, maka tanah tersebut tidak bisa langsung diambil/dikelola oleh kepala desa sementara, hak-haknya akan diberikan tidak dalam tanah pecatu, tanah tersebut baru diberikan setelah terpilih kepala desa baru.
Pemerintah daerah untuk kepentingan umum dapat mengambil alih suatu tanah pecatu namun harus mengganti dengan tanah lain yang jenis dan potensi peruntukannya sama dengan tanah yang diambil tersebut. Apabila terjadi permasalah peralihan tanah pecata dari kepala desa lama ke kepala desa baru, camat dipanggil untuk berlaku sebagai mediator sementara keputusan ditentukan oleh masyarakat melalui tokoh adat.

\subsection{Profil Kasus Pertanahan}

Dari table 4.31 di atas menunjukkan masalah penguasaan dan pemilikan tanah merupakan masalah yang tertinggi di Provinsi Nusa Tenggara Barat, yang kedua adalah masalah pelaksanaan putusan pengadilan, dan ketiga adalah masalah prosedur penetapan hak dan pendaftaran tanah dan batas/ letak bidang tanah, adapun untuk Kota

TABEL 4.31. TIPOLOGI MASALAH PERTANAHAN

\begin{tabular}{|c|c|c|c|c|c|c|c|}
\hline NO. & TIPOLOGI & KANWIL & $\begin{array}{c}\text { KOTA } \\
\text { MATARAM }\end{array}$ & $\begin{array}{c}\text { KAB } \\
\text { LOMBOK } \\
\text { BARAT }\end{array}$ & $\begin{array}{c}\text { KAB } \\
\text { LOMBOK } \\
\text { UTARA }\end{array}$ & $\begin{array}{c}\text { KAB } \\
\text { LOMBOK } \\
\text { TENGAH }\end{array}$ & $\begin{array}{l}\text { KAB } \\
\text { LOMBOK } \\
\text { TIMUR }\end{array}$ \\
\hline 1. & $\begin{array}{l}\text { Masalah Penguasaan } \\
\text { dan Pemilikan Tanah }\end{array}$ & $50 \%$ & $100 \%$ & $26 \%$ & $20 \%$ & $95 \%$ & - \\
\hline 2. & $\begin{array}{l}\text { Masalah batas/ } \\
\text { letak bidang tanah }\end{array}$ & $10 \%$ & - & $23 \%$ & $55 \%$ & $5 \%$ & - \\
\hline 3. & $\begin{array}{l}\text { Masalah prosedur } \\
\text { Penetapan Hak \& } \\
\text { Pendaftaran Tanah }\end{array}$ & $10 \%$ & - & $10 \%$ & $15 \%$ & - & - \\
\hline 4. & $\begin{array}{l}\text { Masalah pelaksanaan } \\
\text { putusan pengadilan }\end{array}$ & $30 \%$ & - & $20 \%$ & $10 \%$ & - & - \\
\hline 5. & Masalah tanah ulayat & - & - & $13 \%$ & - & - & - \\
\hline 6. & $\begin{array}{l}\text { Masalah tanah obyek } \\
\text { Landreform }\end{array}$ & - & - & - & - & - & - \\
\hline 7. & $\begin{array}{l}\text { Masalah ganti rugi } \\
\text { tanah ex. Partikelir }\end{array}$ & - & - & - & - & - & - \\
\hline 8. & $\begin{array}{l}\text { Masalah pengadaan } \\
\text { tanah }\end{array}$ & - & - & $6 \%$ & - & - & - \\
\hline
\end{tabular}

Sumber : Hasil Pengumpulan Data, 2013 
TABEL 4.32. TIPOLOGI KASUS PERTANAHAN HASIL RDP

\begin{tabular}{|l|l|c|c|c|c|c|c|}
\hline NO. & \multicolumn{1}{|c|}{ TIPOLOGI } & KANWIL & $\begin{array}{c}\text { KOTA } \\
\text { MATARAM }\end{array}$ & $\begin{array}{c}\text { KAB } \\
\text { LOMBOK } \\
\text { BARAT }\end{array}$ & $\begin{array}{c}\text { KAB } \\
\text { LOMBOK } \\
\text { UTARA }\end{array}$ & $\begin{array}{c}\text { KAB } \\
\text { LOMBOK } \\
\text { TENGAH }\end{array}$ & $\begin{array}{c}\text { KAB } \\
\text { LOMBOK } \\
\text { TIMUR }\end{array}$ \\
\hline 1. & $\begin{array}{l}\text { Masyarakat } \\
\text { dengan swasta }\end{array}$ & $100 \%$ & - & $100 \%$ & - & $40 \%$ & - \\
\hline 2. & TNI dengan POLRI & - & - & - & - & - & - \\
\hline 3. & Masyarakat Adat & - & - & - & - & $15 \%$ & - \\
\hline 4. & Kehutanan & - & - & - & $100 \%$ & $20 \%$ & - \\
\hline 5. & ESDM/Pertambangan & - & - & - & - & - & - \\
\hline 6. & BUMN & - & $100 \%$ & - & - & $10 \%$ & - \\
\hline 7. & PU/Departemen & - & - & - & - & $15 \%$ & - \\
\hline
\end{tabular}

Sumber : Hasil Pengumpulan Data, 2013

TABEL 4.33. FREKWENSI KASUS PERTANAHAN DAN PENYELESAIANNYA

\begin{tabular}{|c|l|c|c|c|c|c|}
\hline NO. & WILAYAH PENELITIAN & SENGKETA & KONFLIK & MEDIASI & LITIGASI & $\begin{array}{c}\text { EXECUTOIR } \\
\text { BESLAAG }\end{array}$ \\
\hline 1. & Kanwil & 124 & 6 & 1 & 7 & - \\
\hline 2. & Kota Mataram & 6 & - & 5 & 1 & - \\
\hline 3. & Kab Lombok Barat & 5 & - & 3 & 3 & - \\
\hline 4. & Kab Lombok Utara & 1 & - & 1 & 2 & - \\
\hline 5. & Kab Lombok Tengah & 10 & - & 10 & 4 & 2 \\
\hline 6. & Kab Lombok Timur & - & - & - & 20 & - \\
\hline
\end{tabular}

Sumber : Hasil Pengumpulan Data, 2013

Mataram permasalahan yang ada seluruhnya mengenai penguasaan dan Pemilikan tanah, untuk Kab. Lombok Barat dan Kab. Lombok tengah permasalahan tertinggi mengenai penguasaan dan pemilikan tanah, sedangkan untuk kab. Lombok Utara permasalahan tertinggi mengenai batas/letak bidang tanah.

Untuk Tipologi berdasarkan RDP, baik Kanwil, kab. Lombok Barat maupun Kab. Lombok tengah permasalahan yang dominan adalah antara masyarakat dengan swasta, untuk Kota Mataram seluruhnya permasalahan BUMN, Kab. Lombok Utara seluruhnya permasalahan dengan kehutanan.
Tabel 4.33 menunjukkan frekwensi kasus pertanahan tertinggi di Kanwil adalah sengketa, sedangkan konflik hanya lima persen dari sengketa, untuk Kab/Kota hanya ada sengketa tidak ditemukan konflik.

Dari tabel 4.34 menunjukkan bahwa selain aspek yuridis dalam penanganan kasus pertanahan dilakukan penelitian fisik dan sosiologis agar diperoleh informasi mengenai sikap masyarakat dalam upaya penyelesaian kasus pertanahan dengan observasi ke lokasi untuk mendapatkan data dan informasi penyebab masalah dari aspek lainnya yang bersifat internal. 
TABEL 4.34. ASPEK YANG DITELITI DALAM PENELITIAN MENGENAI AKAR MASALAH

\begin{tabular}{|l|l|l|}
\hline NO & \multicolumn{1}{|c|}{ WILAYAH PENELITIAN } & $\begin{array}{l}\text { APAKAH SELAIN ASPEK YURIDIS JUGA DITELITI } \\
\text { MENGENAI ASPEK SOSIOLOGI DAN ASPEK LAIN } \\
\text { SEHINGGA TERJADI MASALAH TERSEBUT }\end{array}$ \\
\hline 1. & Kanwil & $\begin{array}{l}\text { Ya, dalam penanganan kasus pertanahan harus dilakukan } \\
\text { pengkajian dan penelitian secara utuh dan menyeluruh, } \\
\text { sehingga dilakukan penelitian fisik dan sosiologis agar } \\
\text { diperoleh informasi mengenai sikap masyarakat dalam } \\
\text { upaya penyelesaian kasus pertanahan }\end{array}$ \\
\hline 2. & Kota Mataram & $\begin{array}{l}\text { Tidak, karena setiap permasalahan mempunyai } \\
\text { karakteristik dan penyebab yang berbeda-beda dan } \\
\text { tidak semua masalah pertanahan berdampak social bagi } \\
\text { masyarakat }\end{array}$ \\
\hline 3. & Kab Lombok Barat & $\begin{array}{l}\text { Ya, setelah observasi ke lokasi kami juga mendapatkan } \\
\text { data dan informasi penyebab masalah dari aspek lainnya } \\
\text { yang bersifat internal }\end{array}$ \\
\hline 4. & Kab Lombok Utara & $\begin{array}{l}\text { Ya, setelah observasi ke lokasi, mendapatkan data dan } \\
\text { informasi penyebab masalah dari aspek lain yang bersifat } \\
\text { internal }\end{array}$ \\
\hline 5. & Kab Lombok Tengah & Ya \\
\hline 6. & Kab Lombok Timur & Ya, semua aspek menjadi dasar kajian \\
\hline
\end{tabular}

Sumber: Hasil Pengumpulan Data, 2013

Sedangkan untuk responden Kota Mataram menyatakan setiap permasalahan mempunyai karakteristik dan penyebab yang berbedabeda dan tidak semua masalah pertanahan berdampak social bagi masyarakat.

Mengenai Tim Khusus Penyelesaian Kasus Pertanahan sebagaimana disajikan dalam tabel 4.35 baik di kanwil, Kab. Lombok Barat, Kab. Lombok Utara. Kab. Lombok Tengah, dan Kab. Lombok Timur sudah dibentuk, kecuali di Kota Mataram.
Pada tabel 4.36 menunjukkan bahwa beberapa responden belum dapat melakukan eksekusi berita acara kesepakatan karena beberapa hal, antara lain karena masih dalam tahap penanganan belum sampai ke tahap akhir, sedangkan yang sudah dilaksanakan di Kab. Lombok Timur dan Kanwil, contohnya Penyelesaian Konflik Pertanahan antara PT WAH dengan masyarakat yang dapat diselesaikan secara win-win solution. 
TABEL 4.35. TIM KHUSUS PENYELESAIAN KASUS PERTANAHAN

\begin{tabular}{|l|l|l|}
\hline NO & \multicolumn{1}{|c|}{ WILAYAH PENELITIAN } & $\begin{array}{l}\text { APAKAH SELAIN ASPEK YURIDIS JUGA DITELITI } \\
\text { MENGENAI ASPEK SOSIOLOGI DAN ASPEK LAIN } \\
\text { SEHINGGA TERJADI MASALAH TERSEBUT }\end{array}$ \\
\hline 1. & Kanwil & $\begin{array}{l}\text { Ada, Sesuai Dengan SK Kakanwil BPN Prov NTB } \\
\text { Tanggal } 13 \text { Maret2013 Nomor : 32/KEP-54/III/2013 } \\
\text { Tentang Pembentukan Tim Penanganan dan } \\
\text { Penyelesaian Permasalahan yang Berpotensi Konflik } \\
\text { Strategis di Prov. NTB }\end{array}$ \\
\hline 2. & Kota Mataram & \begin{tabular}{l} 
Tidak ada \\
\hline 3.
\end{tabular} \\
\hline 4. & Kab Lombok Barat & Kab Lombok Utara \\
\hline 5. & Kab Lombok Tengah & Ada \\
\hline 6. & Kab Lombok Timur & Ada, sesuai dengan kasus yang ditangani \\
\hline
\end{tabular}

Sumber : Hasil Pengumpulan Data, 2013

Berdasarkan dari tabel 4.37. dapat dijelaskan bahwa, saat ini beberapa sampel kantor pertanahan di wilayah provinsi NTB yaitu Kota Mataram, kab. Lombok Barat, Kab. Lombok Utara, tidak memiliki peta/data sebaran permasalahan pertanahan. Kecuali di kab. Lombok Tengah dan kab. Lombok Timur sudah ada peta/data sebaran walaupun sifatnya masih sporadic sesuai dengan masalah yang timbul. 


\section{TABEL 4.36. EKSEKUSI BERITAACARA TIM PENYELESAIAN KASUS}

\begin{tabular}{|l|l|l|}
\hline NO & \multicolumn{1}{|c|}{ WILAYAH PENELITIAN } & $\begin{array}{r}\text { EKSEKUSI SESUAI DENGAN BERITA ACARA HASIL } \\
\text { TIM PENYELESAIAN KASUS }\end{array}$ \\
\hline 1. & Kanwil & $\begin{array}{l}\text { Ada, contohnya Penyelesaian Konflik Pertanahan antara } \\
\text { PT WAH dengan masyarakat secara win-win solution }\end{array}$ \\
\hline 2. & Kota Mataram & Masih dalam tahap penanganan belum hasil \\
\hline 3. & Kab Lombok Barat & Masih dalam tahap penanganan, belum tahap akhir \\
\hline 4. & Kab Lombok Utara & Belum ada \\
\hline 5. & Kab Lombok Tengah & Langsung di eksekusi \\
\hline 6. & Kab Lombok Timur & \\
\hline
\end{tabular}

Sumber: Hasil Pengumpulan Data, 2013

TABEL 4.37. PETADATA SEBARAN SENGKETA/KONFLIK

\begin{tabular}{|l|l|l|}
\hline NO & \multicolumn{1}{|c|}{ WILAYAH PENELITIAN } & \multicolumn{1}{|c|}{ PETA/DATA SEBARAN SENGKETA/KONFLIK } \\
\hline 1. & Kanwil & $\begin{array}{l}\text { Sedang dalam tahap pembuatan database sengketa } \\
\text { konflik dan perkara pertanahan disertai peta sebarannya }\end{array}$ \\
\hline 2. & Kota Mataram & Tidak ada \\
\hline 3. & Kab Lombok Barat & Tidak ada \\
\hline 4. & Kab Lombok Utara & Tidak ada \\
\hline 5. & Kab Lombok Tengah & Sebagian ada \\
\hline 6. & Kab Lombok Timur & $\begin{array}{l}\text { Sudah ada, tetapi sebarannya masih sporadic sesuai } \\
\text { dengan masalah yang timbul }\end{array}$ \\
\hline
\end{tabular}




\section{DOKUMENTASI PENELITIAN}

Dalam pelaksanaan penelitian peningkatan peran mediator dalam kepastian penyelesaian sengketa dan konflik pertanahan terdapat beberapa pengambilan gambar berupa foto yang secara nyata menggambarkan dan menjelaskan proses pelaksanaan penelitian. Dengan dokumentasi tersebut dimaksudkan akan diperoleh suatu bukti otentik terhadap penelitian yang dilakukan. Selain itu, fotofoto yang diperoleh dapat menjadi pelengkap data guna menyempurnakan penelitian yang dilakukan. Dokumentasi penelitian yang diperoleh adalah sebagai berikut :
Pada gambar 4.6. menggambarkan tentang diskusi yang sedang berlangsung tentang penelitian peran mediator dalam kepastian penyelesaian sengketa dan konflik pertanahan pada saat tim penelitian melakukan pengumpulan data di Provinsi Lampung yang dilakukan dengan komponen dari kantor pertanahan tersebut.

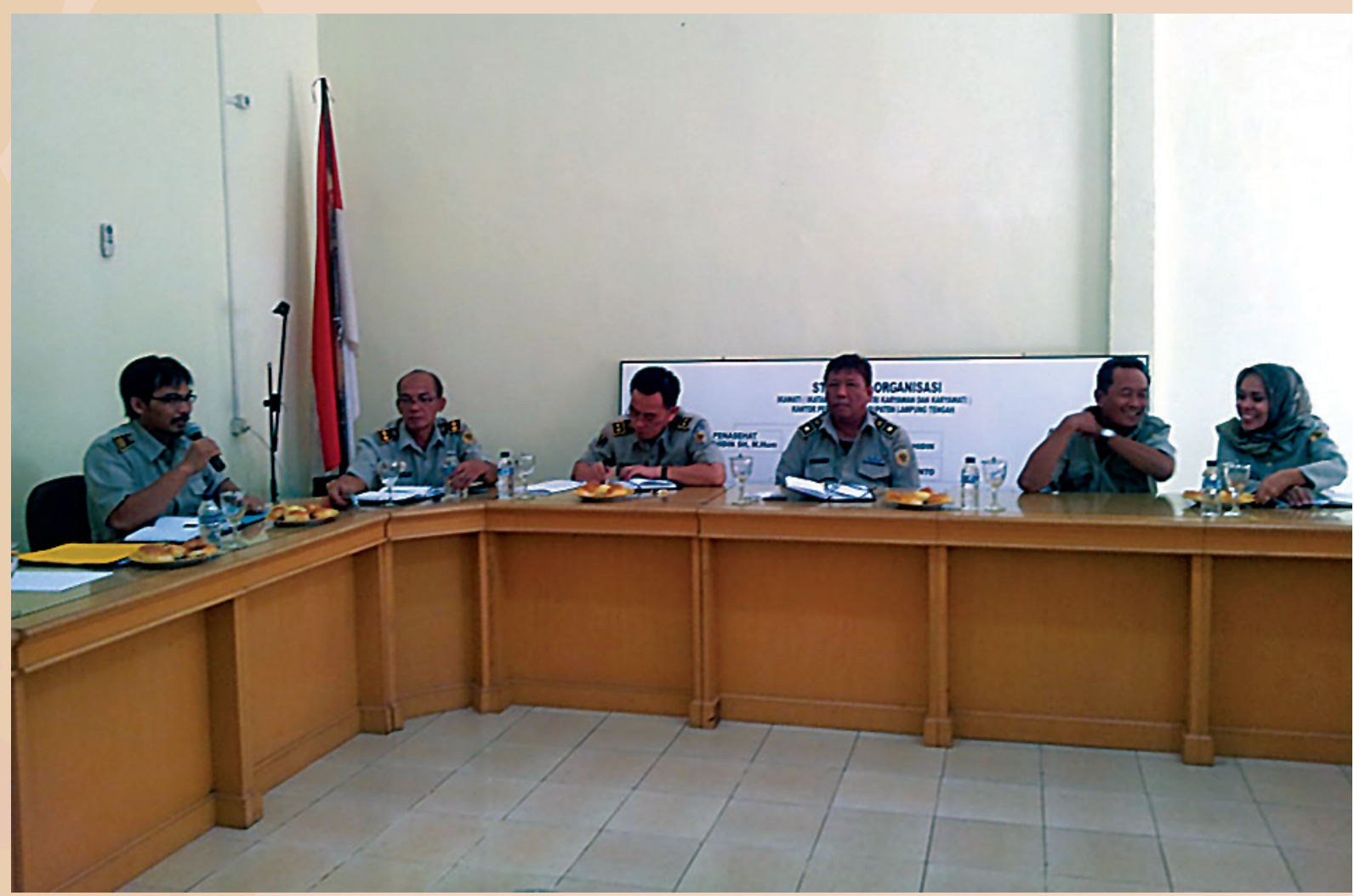

Gambar 4.6. Pelaksanaan Diskusi Di Kantor Pertanahan Kabupaten Lampung Tengah 


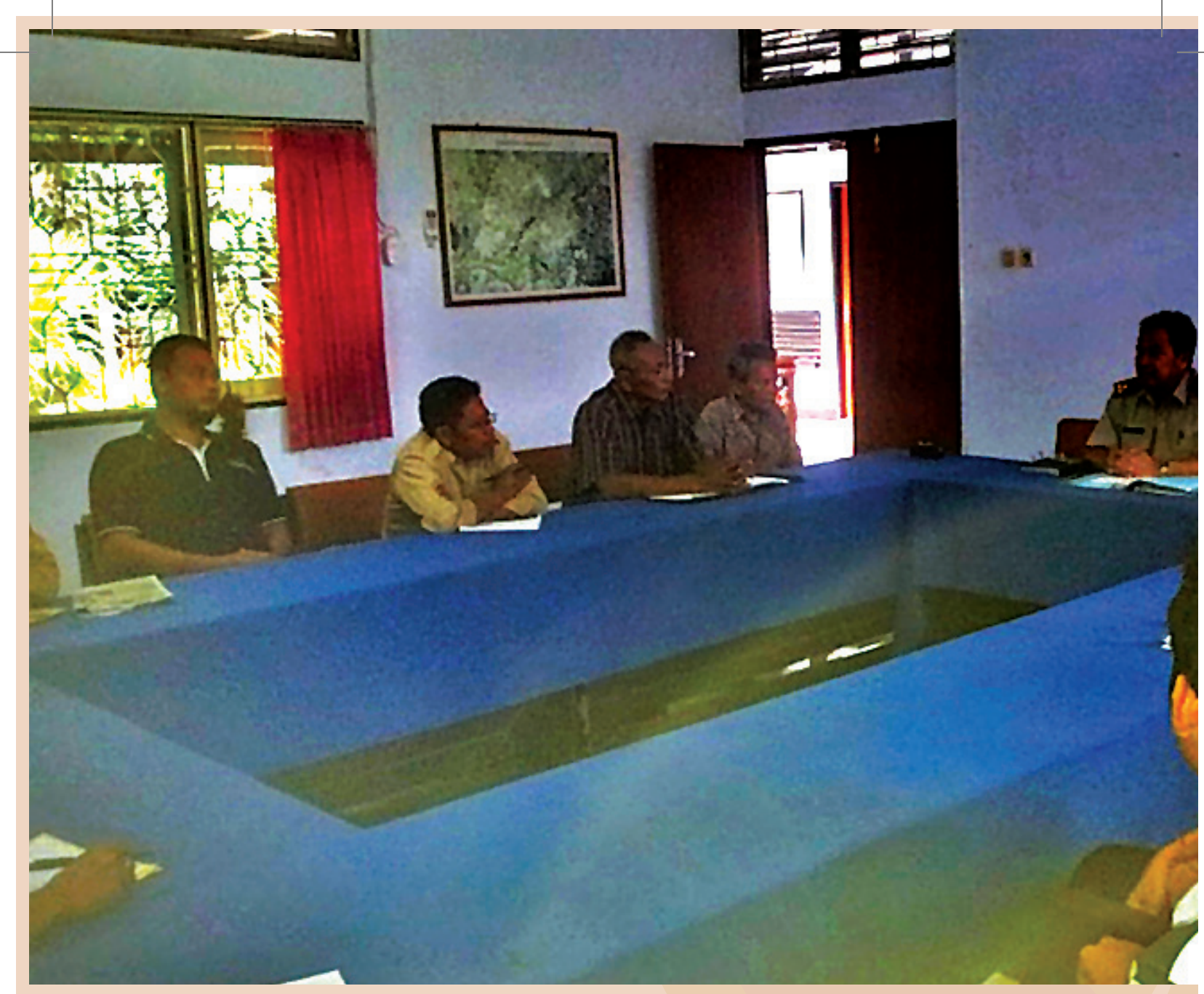

Gambar 4.7. Pelaksanaan Mediasi Di Nusa Tenggara Barat

Pada gambar 4.7. menggambarkan tentang mediasi yang sedang berlangsung antara masyarakat di Provinsi Nusa Tenggara Barat dengan Kantor Pertanahan Kabupaten Lombok Barat.

Pada gambar 4.8. menggambarkan tentang Konsultasi yang dilakukan oleh DPRD Kabupaten Tapin di Kantor Wilayah Kalimantan Selatan mengenai permasalahan pertanahan yang terdapat di wilayahnya.
Pada gambar 4.9. menggambarkan kegiatan seminar laporan akhir penelitian yang pelaksanaanya dilaksanakan di kota Jakarta. Dalam kegiatan ini terdapat beberapan narasumber dan moderator yang secara khusus diundang untuk memberikan masukan lebih dalam lagi dalam penyempurnaan laporan penelitian yang disusun. 

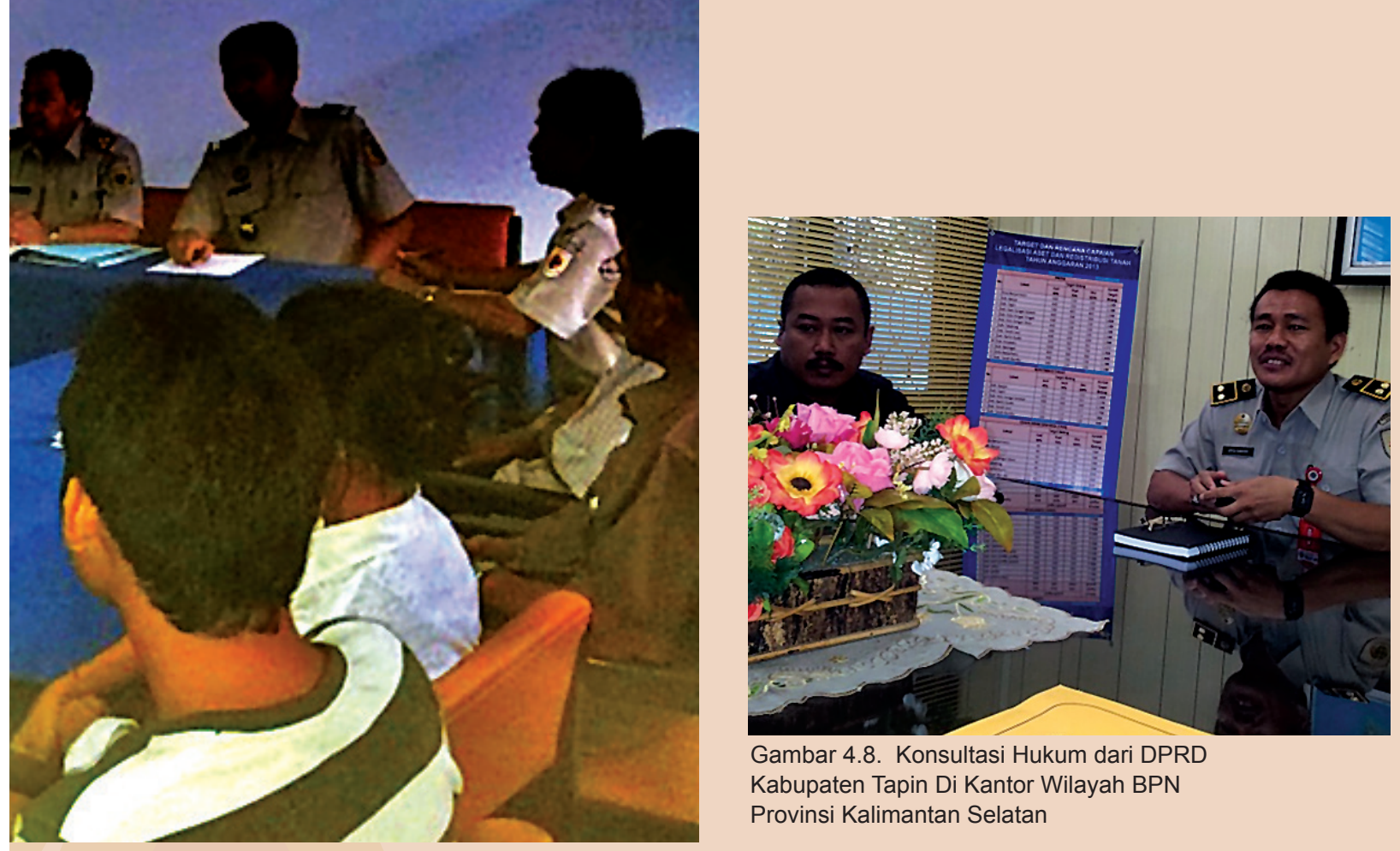

Gambar 4.8. Konsultasi Hukum dari DPRD

Kabupaten Tapin Di Kantor Wilayah BPN

Provinsi Kalimantan Selatan

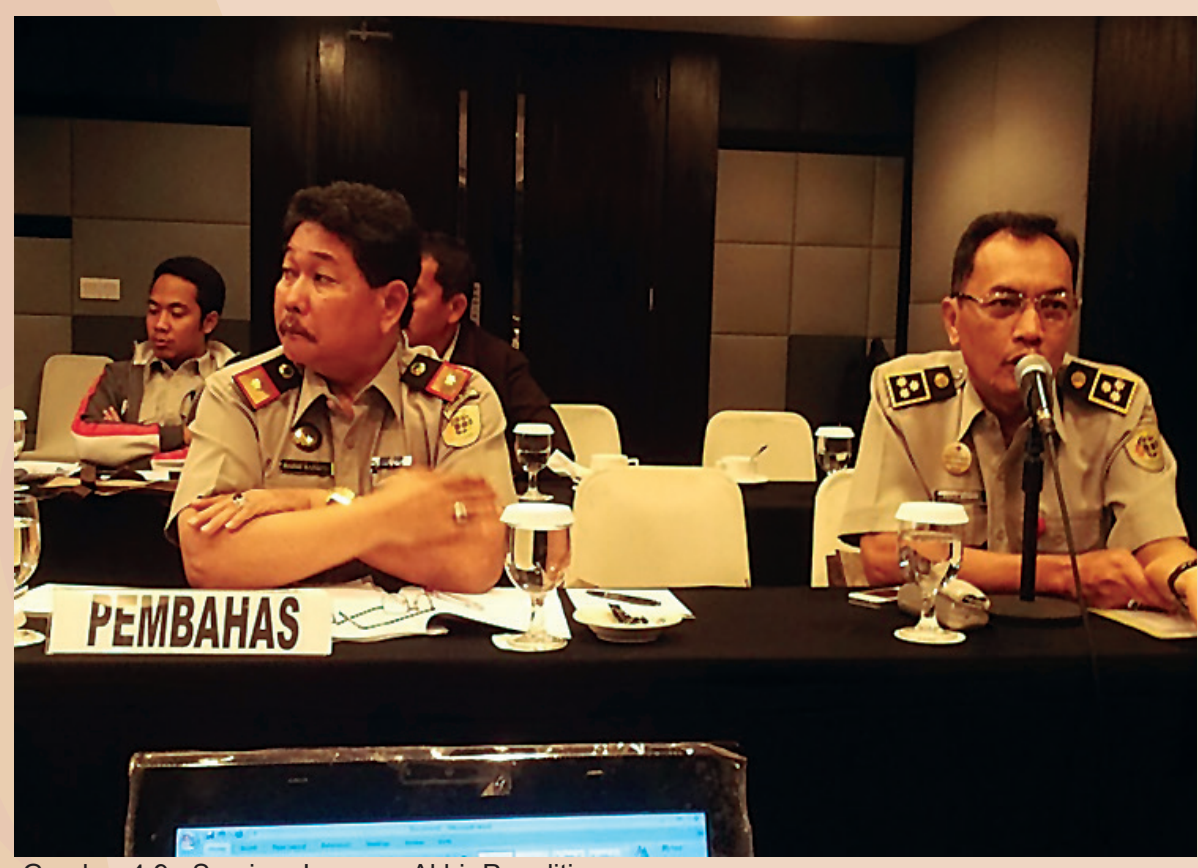




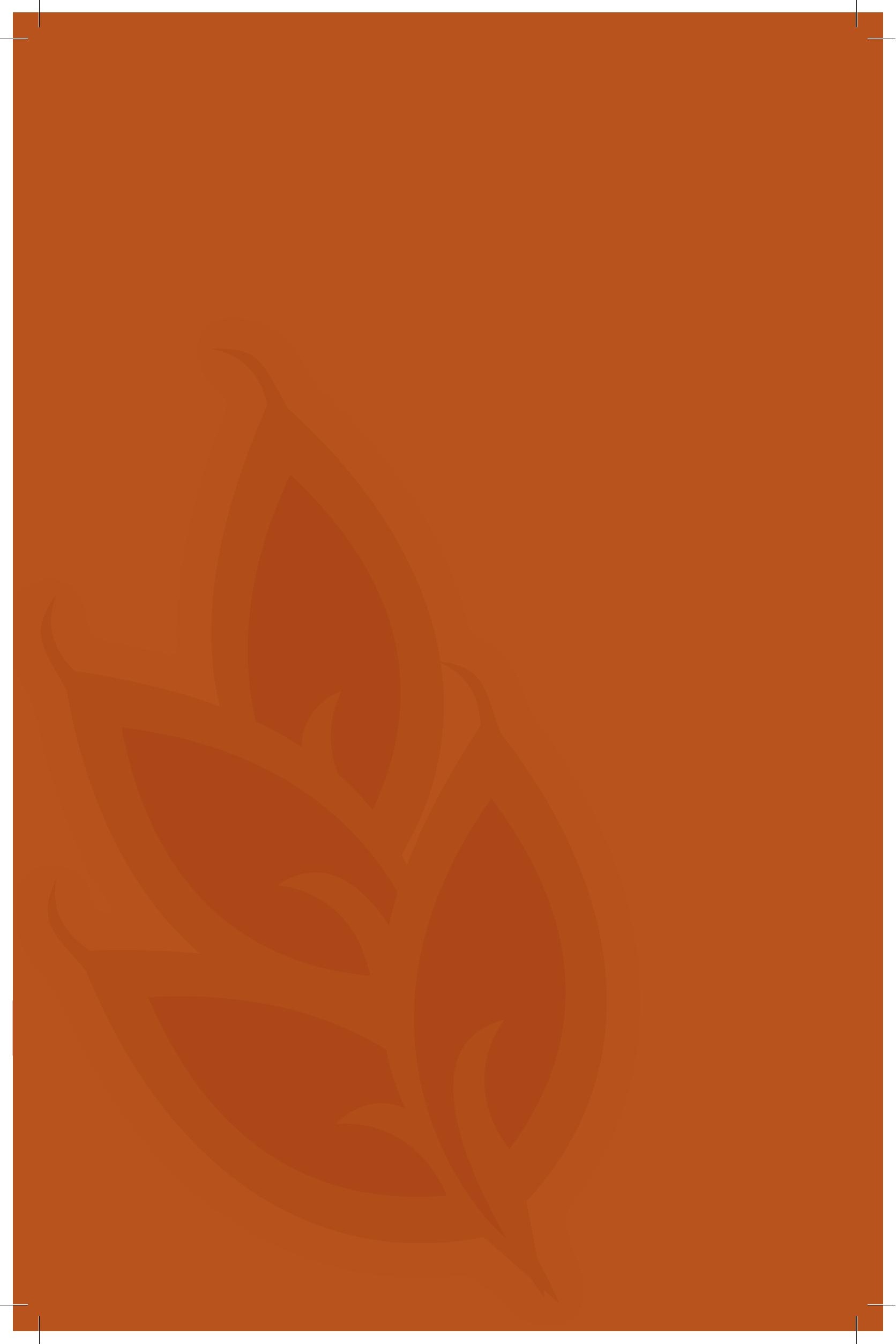




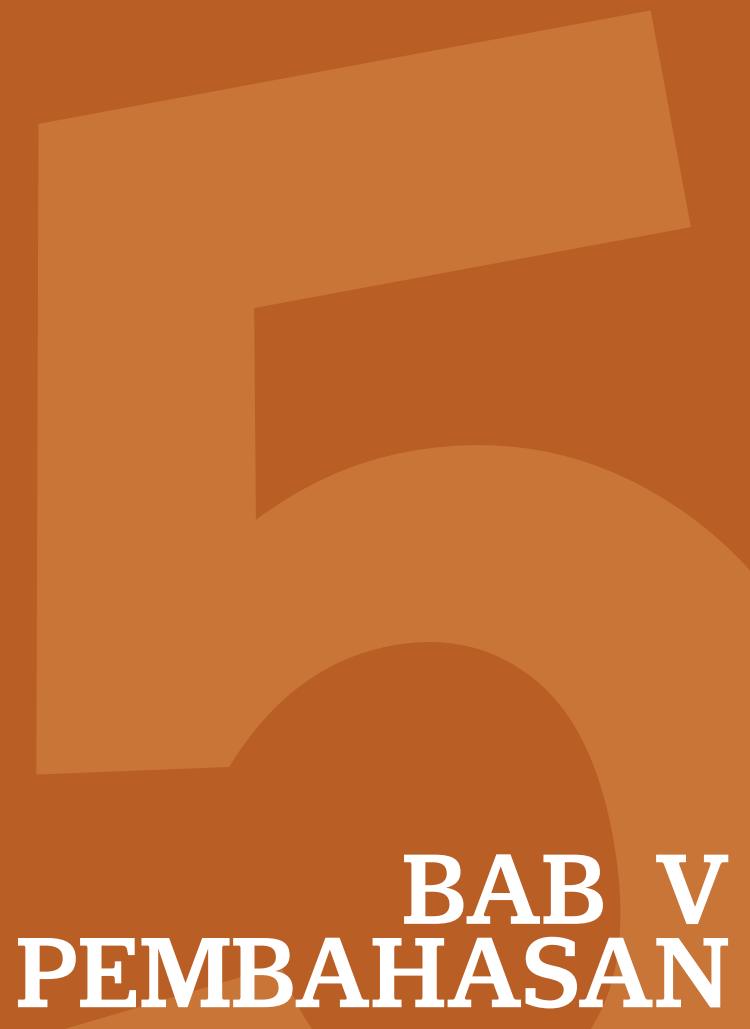


Berdasarkan pengumpulan

data yang telah di

laksanakan di lima lokasi

penelitian yaitu Provinsi

Maluku, Lampung,

Kalimantan Selatan, Jawa

Barat, Nusa Tenggara

Barat didapatkan tipologi

masalah pertanahan tahun

2012 yang menggambarkan

tingkat volume masalah

pertanahan yang terjadi di

masing - masing sampel

lokasi penelitian.

\section{PROFIL KASUS PERTANAHAN}

Banyak faktor yang mempengaruhi tingkat volume permasalahan tersebut, seperti karakterisitik dari masyarakat yang berbeda - beda untuk setiap daerah, kurangnya tingkat pengetahuan masyarakat tentang hukum pertanahan yang berlaku di Indonesia, pemeliharaan dan updating data yang dilakukan secara internal tidak berjalan dengan baik.

Tingkat volume masalah pertanahan pada tabel 5.1. Tipologi Masalah Pertanahan Lokasi Penelitian Tahun 2012 dan gambar 5.1. Tipologi Masalah Pertanahan Lokasi Penelitian Tahun 2012 dapat digunakan sebagai indikator masalah pertanahan yang banyak dialami di seluruh wilayah Indonesia dan dapat diperuntukkan dalam membuat formula penyelesaian permasalahan pertanahan tersebut secara efektif dan efisien.

\section{TABEL 5.1. TIPOLOGI MASALAH PERTANAHAN LOKASI PENELITIAN TAHUN 2012}

\begin{tabular}{|c|c|c|c|c|c|c|}
\hline NO. & $\begin{array}{l}\text { TIPOLOGI MASALAH } \\
\text { PERTANAHAN }\end{array}$ & MALUKU & LAMPUNG & $\begin{array}{l}\text { KALIMANTAN } \\
\text { SELATAN }\end{array}$ & $\begin{array}{l}\text { JAWA } \\
\text { BARAT }\end{array}$ & \begin{tabular}{|c|} 
NUSA \\
TENGGARA \\
BARAT
\end{tabular} \\
\hline 1 & $\begin{array}{l}\text { Masalah Penguasaan } \\
\text { dan Pemilikan }\end{array}$ & 50 & 92 & 18 & 146 & 30 \\
\hline 2 & $\begin{array}{l}\text { Masalah Prosedur Penetapan } \\
\text { Hak dan Pendaftaran Tanah }\end{array}$ & 3 & 23 & 0 & 27 & 4 \\
\hline 3 & $\begin{array}{l}\text { Masalah Batas Dan/Atau } \\
\text { Letak Bidang Tanah }\end{array}$ & 21 & 16 & 20 & 3 & 15 \\
\hline 4 & Masalah ganti rugi Ex-Partikelir & 2 & 1 & 0 & 1 & 0 \\
\hline 5 & Masalah Tanah Ulayat & 12 & 4 & 0 & 1 & 1 \\
\hline 6 & $\begin{array}{l}\text { Masalah Tanah Obyek } \\
\text { Landreform }\end{array}$ & 4 & 2 & 0 & 1 & 0 \\
\hline 7 & Masalah Pengadaan Tanah & 5 & 0 & 0 & 1 & 6 \\
\hline 8 & $\begin{array}{l}\text { Masalah Pelaksanaan } \\
\text { Putusan Pengadilan }\end{array}$ & 3 & 1 & 1 & 3 & 6 \\
\hline 9 & $\begin{array}{l}\text { Masalah Peruntukan dan } \\
\text { Penggunaan Tanah }\end{array}$ & 0 & 1 & 0 & 0 & 0 \\
\hline
\end{tabular}

Sumber: Hasil Pengumpulan Data, 2013 


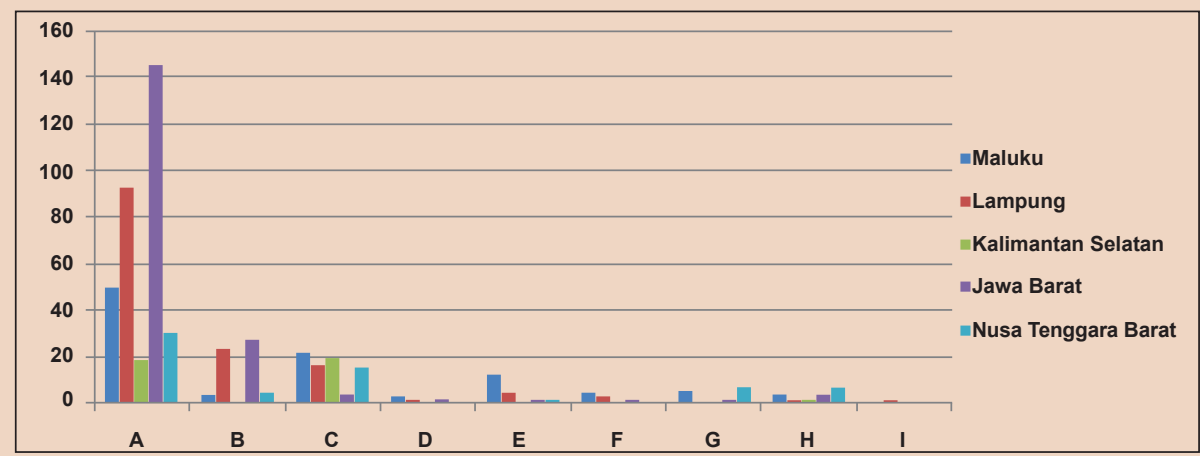

Gambar 5.1. Tipologi Masalah Pertanahan Lokasi Penelitian Tahun 2012

\section{Keterangan :}

A : Masalah Penguasaan dan Pemilikan

B : Masalah Prosedur Penetapan Hak dan Pendaftaran Tanah

C : Masalah Batas Dan/ Atau Letak Bidang Tanah

D : Masalah ganti rugi Ex-Partikelir

E : Masalah Tanah Ulayat

F : Masalah Tanah Obyek Landreform

G : Masalah Pengadaan Tanah

$\mathrm{H}$ : Masalah Pelaksanaan Putusan Pengadilan

I : Masalah Peruntukan dan Penggunaan Tanah

Berdasarkan Perkaban No. 3 Tahun 2011 tentang tentang Pengelolaan Pengkajian dan Penanganan Kasus Pertanahan, BPN RI berperan aktif dalam penyelesaian kasus pertanahan, hal ini dibuktikan dengan terbentuknya tim khusus penyelesaian pertanahan yang terdapat di beberapa lokasi sampel penelitian. Pada penelitian ini didapatkan bahwa tim khusus penyelesaian pertanahan yang terbentuk tidak hanya beranggotakan internal BPN saja, melainkan banyak juga yang melibatkan pihak lain seperti instansi pemerintah lainnya, perguruan tinggi, dan LSM. Terdapat beberapa daerah yang melakukan pembentukan tim ini yang ditetapkan dalam Surat Keputusan (SK) untuk satu tahun waktu pelaksanaan dan/ atau pembentukan tim berdasarkan urgensi masalah pertanahan yang dihadapi saja. Keberadaan dari tim khusus penyelesaian pertanahan ini di lokasi sampel penelitian dapat dilihat pada tabel 5.2. Tim Khusus Penyelesaian Kasus Pertanahan.

Tidak semua daerah penelitian mempunyai tim khusus penyelesaian kasus pertahanan, hanya daerah yang sering terjadi konflik dan sifatnya strategis mempunyai tim khusus tingkat Provinsi seperti Lampung dan Maluku. Sedangkan untuk Kalimantan Selatan, Jawa Barat dan Nusa Tenggara Barat tim penyelesaian kasus pertanahan bersifat temporer dan kasuistis. 
TABEL 5.2. TIM KHUSUS PENYELESAIAN KASUS PERTANAHAN

\begin{tabular}{|c|l|l|}
\hline NO & \multicolumn{1}{|c|}{ PROVINSI } & TIM KHUSUS PENYELESAIAN KASUS PERTANAHAN \\
\hline 1 & Maluku & Ada tim khusus tingkat Provinsi \\
\hline 2 & Lampung & Ada tim khusus tingkat Provinsi \\
\hline 3 & Kalimantan Selatan & $\begin{array}{l}\text { Dibentuk tim khusus berdasarkan SK Ka. Kanwil } \\
\text { Prov Kalimantan Selatan terhadap permasalahan - } \\
\text { permasalahan pertanahan }\end{array}$ \\
\hline 4 & Jawa Barat & $\begin{array}{l}\text { Tidak ada tim khusus (ada tim ad hoc seperti kasus HGU } \\
\text { PT Rajawali, PT Indonesia Power dII) }\end{array}$ \\
\hline 5 & Nusa Tenggara Barat & $\begin{array}{l}\text { Ada, Sesuai Dengan SK Kakanwil BPN Prov NTB Tanggal } \\
13 \text { Maret2013 Nomor : 32/KEP-54/III/2013 Tentang } \\
\text { Pembentukan Tim Penanganan dan Penyelesaian }\end{array}$ \\
& & $\begin{array}{l}\text { Permasalahan yang Berpotensi Konflik Strategis di Prov. } \\
\text { NTB }\end{array}$ \\
\hline
\end{tabular}

Sumber: Hasil Pengumpulan Data, 2013

\section{TABEL 5.3. PETA SEBARAN MASALAH PERTANAHAN}

\begin{tabular}{|c|c|c|c|c|}
\hline \multirow{2}{*}{ NO } & \multirow{2}{*}{ PROVINSI } & \multicolumn{2}{|c|}{ PETA SEBARAN MASALAH PERTANAHAN } & \multirow{2}{*}{ KETERANGAN } \\
\hline & & MEMILIKI & TIDAK MEMILIKI & \\
\hline 1 & Maluku & & V & \\
\hline 2 & Lampung & V & & \\
\hline 3 & Kalimantan Selatan & V & & \\
\hline 4 & Jawa Barat & & V & \\
\hline 5 & Nusa Tenggara Barat & & V & \\
\hline
\end{tabular}

Sumber: Hasil Pengumpulan Data, 2013

Sebagaimana tabel 5.3. Peta Sebaran Masalah Pertanahan dapat dijelaskan bahwa tidak semua lokasi sampel penelitian telah memiliki peta sebaran masalah pertanahan yang terjadi di wilayahnya. Peta sebaran masalah pertanahan yang dimaksud merupakan data secara atribut (belum ada di seluruh lokasi sampel penelitian data secara spesial).

\section{PENGATURAN PENYELESAIAN MASALAH PERTANAHAN MELALUI MEDIASI}

Sebagaimana diuraikan pada tabel 5.4. di atas, hasil penelitian lapangan menunjukkan fakta bahwa yang dijadikan dasar pengaduan dan diterima oleh Kantor Wilayah maupun Kantor Pertanahan selain bukti yuridis berupa bukti surat, sertipikat, surat ukur dan penguasaan secara turun-temurun, juga dapat berupa pengaduan lisan yang dilakukan oleh masyarakat. Pada pengaduan secara lisan diharuskan adanya hubungan hukum antara si pengadu dengan obyek tanah yang terkait.

Tabel 5.5 menguraikan fakta yang diperoleh melalui penelitian lapangan bahwa ternyata penunjukan mediator oleh Kepala Kantor tidak selalu disertai dengan Surat Tugas khusus sebagaimana yang ditentukan dalam Perkaban No. 3 tahun 2011, karena sebagian besar responden beranggapan bahwa pelaksanaan tugas sebagai mediator oleh jajaran pejabat di bidang/seksi Penanganan Sengketa Konflik dan Perkara Pertanahan merupakan pelaksanaan daripada tugas pokok yang melekat padanya (ex officio). 
TABEL 5.4. DASAR PENGADUAN

\begin{tabular}{|l|l|l|}
\hline NO & WILAYAH PENELITIAN & \multicolumn{1}{|c|}{ DASAR PENGADUAN } \\
\hline 1. & Maluku & $\begin{array}{l}\text { Data yuridis kadang ada kadang tidak ada, data yuridis } \\
\text { dapat berupa bukti surat, sertipikat dan surat ukur, yang } \\
\text { menjadi dasar adalah penguasaan secara turun temurun }\end{array}$ \\
\hline 2. & Lampung & $\begin{array}{l}\text { Bukti tertulis sebagai data awal biasa selain pengaduan } \\
\text { dari masyarakat }\end{array}$ \\
\hline 3. & Kalimantan Selatan & $\begin{array}{l}\text { Tertulis, harus disampaikan berdasarkan surat } \\
\text { pengaduan, obyek harus jelas, legal standing dan maksud } \\
\text { pengaduan, serta pencocokan data - data yuridis dan } \\
\text { data fisik dan data pendukung lainnya. }\end{array}$ \\
\hline 4. & Jawa Barat & $\begin{array}{l}\text { Surat pengaduan yang disertai bukti yuridis, namun tidak } \\
\text { sedikit pengaduan yang diajukan tanpa bukti yang jelas } \\
\text { karena banyak masyarakat yang belum mengerti data/ } \\
\text { alas hak yang dibutuhkan sebagai dasar pengaduan }\end{array}$ \\
\hline 5. & Nusa Tenggara Barat & $\begin{array}{l}\text { Adanya bukti hubungan hukum antara pengadu dengan } \\
\text { obyek tanah dengan melampirkan identitas/surat kuasa, } \\
\text { ada bukti atas tanah/yuridis, selain data yuridis tersebut } \\
\text { dilakukan penelitian lapangan untuk menguatkan apakah } \\
\text { pengaduan tersebut mengandung unsure kebenaran atau } \\
\text { tidak }\end{array}$ \\
\hline
\end{tabular}

Sumber: Hasil Pengumpulan Data, 2013

\section{TABEL 5.5. DASAR PELAKSANAAN TUGAS MEDIATOR MEMIMPIN MEDIASI}

\begin{tabular}{|l|l|l|}
\hline NO & WILAYAH PENELITIAN & DASAR PELAKSANAAN TUGAS MEDIATOR MEMIMPIN MEDIASI \\
\hline 1. & Maluku & $\begin{array}{l}\text { Langsung ditangani berdasarkan tupoksi melalui disposisi, } \\
\text { namun tergantung bobot masalahnya, jika bersifat } \\
\text { strategis dan berdampak sosial maka dibekali dengan } \\
\text { surat tugas }\end{array}$ \\
\hline 2. & Lampung & $\begin{array}{l}\text { Untuk melakukan mediasi tidak ada penunjukkan } \\
\text { secara khusus, hanya berdasarkan tupoksi, surat tugas } \\
\text { digunakan untuk penelitian lapangan }\end{array}$ \\
\hline 3. & Kalimantan Selatan & $\begin{array}{l}\text { Dalam pelaksanaan mediasi, tidak selalu dilakukan } \\
\text { dengan surat penunjukkan dari Kepala Kantor, sebab } \\
\text { dilaksanakan di ruang mediasi Kanwil/Kantah dan ex } \\
\text { officio dilaksanakan oleh Kepala Bidang/Kepala Seksi } \\
\text { SKP }\end{array}$ \\
\hline 4. & Jawa Barat & $\begin{array}{l}\text { Surat Tugas untuk mediasi tidak selalu diberikan secara } \\
\text { khusus, kecuali pada Kantor Pertanahan Kota Depok } \\
\text { Kepala Kantor selalu mengeluarkan Surat Tugas untuk } \\
\text { melakukan mediasi }\end{array}$ \\
\hline 5. & Nusa Tenggara Barat & $\begin{array}{l}\text { Pada umumnya tidak diberikan surat tugas untuk mediasi, } \\
\text { karena pelaksanaan mediasi oleh jajaran pejabat di } \\
\text { bidang SKP merupakan pelaksanaan daripada tugas } \\
\text { pokok yang melekat padanya }\end{array}$ \\
\hline
\end{tabular}

Sumber: Hasil Pengumpulan Data, 2013 
TABEL 5.6. TAHAPAN MEKANISME MEDIASI YANG SEHARUSNYA DILAKUKAN

\begin{tabular}{|c|l|c|c|c|c|c|}
\hline NO. & \multicolumn{1}{|c|}{$\begin{array}{c}\text { TIPOLOGI MASALAH } \\
\text { PERTANAHAN }\end{array}$} & MALUKU & LAMPUNG & $\begin{array}{c}\text { KALIMANTAN } \\
\text { SELATAN }\end{array}$ & $\begin{array}{c}\text { JAWA } \\
\text { BARAT }\end{array}$ & $\begin{array}{c}\text { NUSA } \\
\text { TENGGARA } \\
\text { BARAT }\end{array}$ \\
\hline 1. & $\begin{array}{l}\text { Menerima permohonan } \\
\text { mediasi }\end{array}$ & $\mathrm{D}$ & $\mathrm{D}$ & $\mathrm{D}$ & $\mathrm{D}$ & $\mathrm{D}$ \\
\hline 2. & Mengumpulkan informasi & $\mathrm{D}$ & $\mathrm{D}$ & $\mathrm{D}$ & $\mathrm{D}$ & $\mathrm{D}$ \\
\hline 3. & Mengundang para pihak & $\mathrm{D}$ & $\mathrm{D}$ & $\mathrm{D}$ & $\mathrm{D}$ & $\mathrm{D}$ \\
\hline 4. & Menyiapkan tempat & $\mathrm{D}$ & $\mathrm{D}$ & $\mathrm{D}$ & $\mathrm{D}$ & $\mathrm{D}$ \\
\hline 5. & Memimpin diskusi & $\mathrm{D}$ & $\mathrm{D}$ & $\mathrm{D}$ & $\mathrm{D}$ & $\mathrm{D}$ \\
\hline 6. & $\begin{array}{l}\text { Memelihara atau menjaga } \\
\text { aturan aturan perundingan }\end{array}$ & $\mathrm{D}$ & $\mathrm{D}$ & $\mathrm{D}$ & $\mathrm{D}$ & $\mathrm{D}$ \\
\hline 7. & $\begin{array}{l}\text { Mendorong para pihak } \\
\text { untuk menyampaikan } \\
\text { masalah dan kepentingan- } \\
\text { nya secara terbuka }\end{array}$ & $\mathrm{D}$ & $\mathrm{D}$ & $\mathrm{D}$ & $\mathrm{D}$ & $\mathrm{D}$ \\
\hline 8. & $\begin{array}{l}\text { Mendorong para pihak } \\
\text { agar menyadari bahwa } \\
\text { Sengketa bukan pertarung- } \\
\text { an yang harus dimenang- } \\
\text { kan tetapi diselesaikan }\end{array}$ & $\mathrm{D}$ & $\mathrm{D}$ & $\mathrm{D}$ & $\mathrm{D}$ & $\mathrm{D}$ \\
\hline 9. & $\begin{array}{l}\text { Mendengar, mencatat, dan } \\
\text { mengajukan pertanyaan }\end{array}$ & $\mathrm{D}$ & $\mathrm{D}$ & $\mathrm{D}$ & $\mathrm{D}$ & $\mathrm{D}$ \\
\hline 10. & $\begin{array}{l}\text { Membantu para pihak } \\
\text { mencapai titik temu }\end{array}$ & $\mathrm{D}$ & $\mathrm{D}$ & $\mathrm{D}$ & $\mathrm{D}$ & $\mathrm{D}$ \\
\hline
\end{tabular}

Sumber: Hasil Pengumpulan Data, 2013

Tahapan mekanisme mediasi sebagaimana dimuat dalam table 5.6 diatas, hampir semuanya dilaksanakan oleh Kantor Wilayah maupun Kantor Pertanahan. Tahapan mediasi diatas jika dibandingkan dengan tahapan mediasi yang diatur pada Keputusan KaBPN No. 34 tahun 2007 menunjukkan bahwa yang diatur dalam Keputusan KaBPN No. 34 tahun 2007 lebih detail, sebagaimana dibawah ini:

1. Persiapan untuk mempertemukan kedua belah pihak

2. Undangan

3. Pelaksanaan kegiatan mediasi (Mengatasi hambatan hubungan antar pihak (hubungan personal antar pihak), Mencairkan suasana diantara kedua belah pihak yang bersengketa, suasana akrab, tidak kaku, Menjelaskan peran mediator)

4. Klarifikasi para pihak

5. Menyamakan pemahaman dan menetapkan agenda musyawarah

6. Identifikasi kepentingan

7. Penentuan opsi yang dipilih

8. Negosiasi akhir

9. Formalisasi kesepakatan.

Adapun Lampiran III Keputusan Kepala BPN RI No 57/KEP-3.43/1/2013 yang mengatur rincian tugas jabatan fungsional mediator yaitu:

1. Menerima hasil analisis masalah pertanahan.

2. Mempelajari hasil analisis masalah per- 
tanahan sebagai bahan persiapan mediasi.

3. Mengumpulkan data pendukung fisik, administrasi dan yuridis sebagai bahan pendukung hasil analisis.

4. Mempersiapkan konsep undangan mediasi untuk para pihak.

5. Mempersiapkan dan melaksanakan gelar mediasi atas SKP pertanahan.

6. Membuat notulen, berita acara dan laporan hasil mediasi.

7. Melaksanakan tugas kedinasan yang diperintahkan atasan baik yang tertulis maupun lisan.

Dari ketiga pola pelaksanaan mediasi diatas, pada dasarnya ketiga pola tersebut dapat saling melengkapi sehingga dapat diperoleh rumusan pola yang lebih lengkap dan menunjang peran mediator dalam melaksanakan mediasi. sebenarnya sangat tergantung pada berapa lama para pihak dapat mencapai titik temu/ kesepakatan untuk mencapai masalahnya, keahlian mediator dalam memainkan perannya tentu akan berpengaruh terhadap berapa cepat kesepakatan dapat dicapai. Pelaksanaan mediasi sebagaimana dalam Perkaban 3/2011 yang memberi tenggat waktu enam bulan, namun terkadang pelaksanaannya dapat melebihi enam bulan sehingga membuat Kantor Wilayah/Kantor Pertanahan akhirnya menyarankan para pihak untuk menempuh jalur litigasi.

\section{PENINGKATAN PERAN MEDIATOR DALAM PERCEPATAN PENYELESAIAN SENGKETA DAN KONFLIK PERTANAHAN}

Kegiatan mediasi yang dilaksanakan selama ini menurut pendapat sebagian besar para responden hanyalah memfasilitasi para

\section{TABEL 5.7. WAKTU PELAKSANAAN MEDIASI}

\begin{tabular}{|c|c|c|}
\hline NO & WILAYAH PENELITIAN & WAKTU PELAKSANAAN MEDIASI \\
\hline 1. & Maluku & $\begin{array}{l}\text { Tergantung kesepakatan para pihak, bisa kurang/lebih } \\
\text { dari enam bulan, terkadang faktor lokasi geografis juga } \\
\text { menjadi masalah }\end{array}$ \\
\hline 2. & Lampung & $\begin{array}{l}\text { Tergantung kesepakatan para pihak bagaimana mencapa } \\
\text { titik temu, bisa kurang/lebih dari enam bulan }\end{array}$ \\
\hline 3. & Kalimantan Selatan & $\begin{array}{l}\text { Pelaksanaan mediasi pada umumnya berjalan dalam } \\
\text { waktu } 6 \text { (enam) bulan sesuai perkaban No.3 Tahun } 2011 \text {, } \\
\text { terhadap yang tidak ada kesepakatan selama tenggang } \\
\text { waktu dimaksud, direkomendasikan untuk jalur litigasi. }\end{array}$ \\
\hline 4. & Jawa Barat & $\begin{array}{l}\text { Pelaksanaan mediasi umumnya dilaksanakan sampai } 3 \\
\text { kali, namun apabila tidak terdapat kesepakatan antara } \\
\text { para pihak maka disarankan untuk menempuh jalur } \\
\text { hukum }\end{array}$ \\
\hline $\begin{array}{l}5 . \\
\text { Sumbe }\end{array}$ & $\begin{array}{l}\text { Nusa Tenggara Barat } \\
\text { r: Hasil Pengumpulan Data, } 2013\end{array}$ & $\begin{array}{l}\text { Ada yang enam bulan selesai, ada yang tidak selesai } \\
\text { dan ada juga yang belum enam bulan sudah selesai, } \\
\text { tergantung titik temu dan kesepakatan para pihak }\end{array}$ \\
\hline
\end{tabular}

Sebagaimana fakta yang terungkap melalui penelitian lapangan yang diuraikan dalam tabel 5.7 di atas, waktu pelaksanaan mediasi pihak yang bersengketa walaupun dikemas sebagai tugas dari mediator, sebagaimana tabel 5.8 berikut: 
TABEL 5.8. FASILITASI/MEDIASI

\begin{tabular}{|l|l|l|}
\hline NO & WILAYAH PENELITIAN & \multicolumn{1}{c|}{ FASILITASI/MEDIASI } \\
\hline 1. & Maluku & $\begin{array}{l}\text { Dari empat lokasi penelitian yang diambil, dua berpendapat fasilitasi } \\
\text { dan dua berpendapat mediasi }(50 \% \mathrm{~F} ; 50 \% \mathrm{M})\end{array}$ \\
\hline 2. Lampung & $\begin{array}{l}\text { Dari lima lokasi penelitian yang diambil, fasilitasi dua, mediasi satu } \\
\text { dan yang berpendapat dilakukan adalah mediasi dan fasilitasi } \\
\text { (keduanya) dua (40\% } \mathrm{F} ; 20 \% \mathrm{M} ; 40 \% \text { keduanya) }\end{array}$ \\
\hline 3. Kalimantan Selatan & $\begin{array}{l}\text { Dari enam lokasi penelitian yang diambil, tiga berpendapat yang } \\
\text { dilakukan adalah fasilitasi, satu mediasi dan dua tidak menjawab } \\
\text { (50\% } \mathrm{F} ; 33,3 \% \text { tidak menjawab) }\end{array}$ \\
\hline 4. Jawa Barat & $\begin{array}{l}\text { Dari lima lokasi penelitian yang diambil semuanya berpendapat yang } \\
\text { dilakukan adalah fasilitasi (100\% M) }\end{array}$ \\
\hline 5. Nusa Tenggara Barat & $\begin{array}{l}\text { Dari enam lokasi penelitian yang diambil empat berpendapat yang } \\
\text { dilakukan fasilitasi dan dua berpendapat mediasi (33,3\% F ; 66,6\% M) }\end{array}$ \\
\hline Sumber: Hasil Pengumpulan Data, 2013
\end{tabular}

Dari tabel 5.8 di atas menunjukkan bahwa sebagian besar responden berpendapat bahwa aparat BPN dalam melaksanakan tugas memediasi para pihak yang bersengketa adalah sebagai fasilitator.

Sebagai seorang fasilitator maka aparat BPN sifatnya hanya mengarahkan para pihak untuk menyelesaikan masalahnya secara musyawarah.

Dalam Perma No. 1 tahun 2008 , menyatakan bahwa mediasi adalah cara penyelesaian sengketa melalui proses perundingan untuk memperoleh kesepakatan para pihak dengan dibantu oleh mediator, sedangkan dalam Perkaban No 3 tahun 2011 disebutkan bahwa gelar mediasi bertujuan antara lain adalah memfasilitasi penyelesaian kasus pertanahan melalui musyawarah dan pemilihan penyelesaian kasus pertanahan. Dari kedua pengertian di atas, sebagian besar responden berpendapat bahwa yang sesuai dengan yang selama ini dilakukan oleh BPN adalah sebagaimana dalam Perkaban No. 3 Tahun 2011.

Menurut John W. Head, mediasi adalah suatu prosedur penengahan dimana seseorang bertindak sebagai kendaraan untuk berkomunikasi antar para pihak , sehingga pandangan mereka yang berbeda atas sengketa tersebut dapat dipahami dan mungkin didamaikan, tetapi tanggung jawab utama tercapainya suatu perdamaian tetap berada di tangan para pihak sendiri. ${ }^{1}$

Pasal 1 butir 5 Peraturan MA No. 1 tahun 2008 menyatakan bahwa, mediator adalah pihak yang bersifat netral dan tidak memihak, yang berfungsi membantu para pihak dalam mencari berbagai kemungkinan penyelesaian sengketa. Para pihak akan mengambil keputusan sendiri atas dasar negosiasi dengan pihak lawannya.

Menurut Fuller salah seorang pakar hukum menyebutkan bahwa fungsi dari seorang mediator ada 7, yakni: ${ }^{2}$

a) Sebagai "katalisator", mengandung pengertian bahwa kehadiran mediator dalam proses perundingan mampu mendorong lahirnya suasana yang konstruktif bagi diskusi.

1. John W. Head, Pengantar Umum Hukum Ekonomi, ELIPS, Jakarta, 2002

2. Suyud Margono, "Alternative Dispute Resolution (ADR) dan Arbitrase". Ghalia Indonesia, Jakarta 2004. 
b) Sebagai "pendidik", berarti seorang harus berusaha memahami aspirasi, prosedur kerja, keterbatasan politis, dan kendala usaha dari para pihak.

c) Sebagai "penerjemah", berarti mediator harus berusaha menyampaikan dan merumuskan usulan pihak yang satu kepada pihak yang lainnya melalui bahasa atau ungkapan yang baik dengan tanpa mengurangi sasaran yang dicapai oleh pengusul.

d) Sebagai "nara sumber" berarti seorang mediator harus mendayagunakan sumber-sumber informasi yang tersedia.

e) Sebagai "penyandang berita jelek", berarti seorang mediator harus menyadari bahwa para pihak dalam proses perundingan dapat bersikap emosional. Untuk itu, mediator harus mengadakan pertemuan terpisah dengan pihak-pihak terkait untuk menampung berbagai usulan.

f) Sebagai "agen realitas", berarti mediator harus berusaha memberikan pengertian secara jelas kepada salah satu pihak bahwa sasarannya tidak mungkin/ tidak masuk akal tercapai melalui perundingan.

g) Sebagai "kambing hitam", berarti seorang mediator harus siap disalahkan, misalnya dalam membuat kesepakatan hasil perundingan.

Dalam pengertian mediasi secara umum, mediator haruslah seorang yang bebas dan tidak berpihak, faktanya pada pelaksanaan mediasi di BPN juga menangani kasus dimana BPN ikut menjadi pihak. Tentunya mekanisme ini perlu diatur apakah untuk kasus dimana BPN menjadi pihak boleh dilakukan mediasi oleh BPN.

Untuk menambah wawasan dan meningkatkan SDM maka pelatihan sebagai mediator terus ditingkatkan melalui diklat mediator kepada aparat BPN baik di Kantor Wilayah maupun Kantor Pertanahan namun demikian dari hasil penelitian lapangan yang dilakukan menunjukkan masih sedikit sekali jajaran staf dan pejabat di Bidang/Seksi Penanganan Sengketa Konflik dan Perkara Pertanahan yang telah mengikuti diklat mediator. Pada lingkup Kantor Wilayah yang menjadi lokasi penelitian yaitu di Maluku, Lampung, Kalimantan Selatan, Jawa Barat dan Nusa Tenggara Barat hanya terdapat tidak lebih dari sepuluh pejabat yang telah mengikuti diklat mediator.

Minimnya pejabat yang telah mengikuti diklat mediator berakibat pada kurangnya pengetahuan tentang bagaimana sebenarnya tata cara mediasi yang baik, karena minimnya sumber daya manusia yang memiliki kemampuan mediasi yang diperoleh melalui diklat mediasi tentu akan menurunkan percepatan pelaksanaan transfer ilmu mediasi ketika kepada jajarannya. Hal ini penting mengingat tahapan mediasi yang memerlukan ketrampilan, sebagai contoh dalam mediasi dikenal istilah kaukus, pengertian kaukus disebutkan dalam pasal 1 butir 4 Peraturan MA di atas, yaitu pertemuan antara mediator dengan salah satu pihak tanpa dihadiri oleh pihak lainnya. Dalam praktek pelaksanaan mediasi di Kantor Wilayah/kantor Pertanahan, sebelum melakukan mediasi, biasanya dilakukan kaukus dengan para pihak yang bersengketa, cara ini diperlukan untuk menghindari gesekan pada saat mediasi antara para pihak.

Kondisi ini semakin dipersulit dengan fakta adanya rotasi-mutasi yang menuntut pejabat di lingkungan BPN RI untuk melakukan tour of duty ditempatkan di bidang/seksi apapun. Hal ini berakibat hasil diklat mediasi yang sudah dilaksanakan tidak dapat mencapai 
sasaran yang diharapkan, contohnya: Pejabat di jajaran Bidang/Seksi SKP yang sudah mengikuti diklat, karena tugas dipindahkan ke seksi lain yang tidak berkaitan dengan bidang penanganan masalah.

Selanjutnya dalam Perma No. 1 tahun 2008 disebutkan bahwa mediasi dilakukan pada pengadilan tingkat pertama, banding, kasasi, dan peninjauan kembali sepanjang perkara tersebut belum diputus. Pada prakteknya berkaitan dengan hal tersebut hasil penelitian di lingkungan Kanwil Jawa Barat di Kota Cimahi, Kota Depok dan Kabupaten Bandung Barat ternyata terdapat putusan pengadilan yang sudah inkracht (PK) tapi tidak/belum dapat dieksekusi kemudian para pihaknya mengajukan permohonan untuk dilakukan mediasi ke BPN. Keadaan yang sama ditemukan pula di lingkungan Kanwil Nusa Tenggara Barat yakni pada Kantor Pertanahan Kabupaten Lombok Timur, dilakukan permohonan mediasi karena pihak yang memegang sertipikat tidak mau menyerahkan sertipikat kepada pihak yang dinyatakan menang.

Wewenang yang dimiliki oleh seorang mediator dalam pelaksanaan mediasi menurut para responden, mediator harus diberikan kewenangan dengan payung hukum yang dapat mengikat para pihak apabila ada putusan mediasi yang sepakat untuk saling bermusyawarah. Dengan adanya payung hukum demikian para responden berharap nantinya hasil mediasi yang sudah disepakati para pihak dapat dijalankan dan persentase hasil kesepakatan yang dilanggar oleh para pihak (wanprestasi) dapat berkurang. Secara lebih terperinci, masukan responden tentang wewenang mediator dapat dilihat dalam tabel 5.9. Wewenang yang seharusnya dimiliki, menurut responden.
Selain kewenangan yang dimiliki, untuk menjalankan perannya dengan baik mediator perlu memahami mengenai hak dan kewajibannya. Responden menyatakan usulannya mengenai hak dan kewajiban mediator sebagaimana tabel 5.10. Hak dan Kewajiban Mediator.

Dengan memahami hak dan kewajiban yang dimiliki olehnya, tentunya mediator dapat bekerja dengan lebih optimal terlebih lagi jika hak dan kewajiban tersebut tertuang dalam sebuah peraturan karena dengan demikian selain lebih mengikat juga dapat memberikan motivasi bagi mediator.

Mengenai kewajiban mediator, Ketua MA RI telah mengeluarkan Pedoman Perilaku Mediator, yang ditetapkan pada tanggal 11 Pebruari 2010, dalam bab II pasal 4 bahwa 1) mediator wajib menyelenggarakan proses mediasi sesuai dengan prinsip penentuan diri sendiri oleh para pihak, 2) mediator wajib memberitahu para pihak pada pertemuan lengkap pertama bahwa semua bentuk keputusan atau penyelesaian yang diambil dalam proses mediasi memerlukan persetujuan para pihak, 3) mediator wajib menjelaskan kepada para pihak pada pertemuan lengkap pertama tentang pengertian dan prosedur mediasi, pengertian kaukus dalam proses mediasi serta peran mediator, 4) mediator wajib menghormati para pihak, antara lain hak untuk konsultasi dengan penasehat hukumnya atau para ahli atau hak untuk keluar dari proses mediasi, 5) mediator wajib menghindari penggunaan ancaman, tekanan atau intimidasi dan paksaan terhadap salah satu atau kedua belah pihak untuk membuat keputusan, 6) mediator wajib menjaga kerahasiaan informasi yang terungkap di dalam proses mediasi, 7) mediator wajib memusnahkan 
catatan-catatan dalam proses mediasi setelah berakhirnya proses mediasi.

Berkaitan dengan point kewajiban mediator di atas, tentunya agak berbeda dengan kewajiban mediator atau dalam hal ini fasilitator di BPN karena untuk point 7 justru catatan itu dapat menjadi alat bukti penting dari proses mediasi yang akan dituangkan dalam suatu berita acara mediasi atau berita acara kesepakatan/perdamaian, demikian juga untuk point 4 justru diharapkan yang terlibat dalam proses mediasi hanya para pihak yang bersengketa saja.

Penelitian lapangan memperoleh masukan dari responden mengenai perlunya diberikan lisensi terhadap mediator yang diatur dalam

\section{TABEL 5.9. WEWENANG YANG SEHARUSNYA DIMILIKI SEORANG MEDIATOR}

\begin{tabular}{|c|c|c|}
\hline No & $\begin{array}{l}\text { WILAYAH } \\
\text { PENELITIAN }\end{array}$ & $\begin{array}{l}\text { WEWENANG YANG SEHARUSNYA DIMILIKI, } \\
\text { MENURUT RESPONDEN }\end{array}$ \\
\hline 1. & Maluku & $\begin{array}{l}\text { Sebagai pengarah dan pengambil keputusan; Mendamaikan para } \\
\text { pihak yang didasari opsi opsi damai yang diterima oleh para pihak } \\
\text { yang bersengketa; Megarahkan dan meminta bahkan menangguhkan } \\
\text { mediasi apabila dipandang perlu jika dapat menimbulkan konflik fisik; } \\
\text { memfasilitasi para pihak yang bersengketa untuk mencapai suatu } \\
\text { penyelesaian terhadap kasus yang sementara dihadapi }\end{array}$ \\
\hline 2. & Lampung & $\begin{array}{l}\text { Mendorong para pihak untuk menyampaikan masalah dan kepentingan } \\
\text { secara terbuka; mendorong para pihak agar menyadari bahwa sengketa } \\
\text { bukan pertarungan yang harus dimenangkan tetapi diselesaikan; } \\
\text { membantu para pihak mencapai titik temu; memfasilitasi dan penghubung } \\
\text { para pihak yang bersengketa; memberikan rekomendasi kepada } \\
\text { para pihak untuk menyelesaikan masalah tanah tersebut, mengambil } \\
\text { keputusan atas sengketa yang dibahas. }\end{array}$ \\
\hline 3. & $\begin{array}{l}\text { Kalimantan } \\
\text { Selatan }\end{array}$ & $\begin{array}{l}\text { Mempersiapkan usulan jadwal pertemuan mediasi yang disepakati para } \\
\text { pihak; Mendorong para pihak secara langsung berperan dalam proses } \\
\text { mediasi; Melakukan kaukus, apabila dipandang perlu; Mengarahan para } \\
\text { pihak menggali kepentingannya dan mencari alternative penyelesaian } \\
\text { yang terbaik bagi para pihak; Menyatakan mediasi gagal bila salah satu } \\
\text { pihak atau para pihak dua kali berturut - turut tidak hadir tanpa alas an } \\
\text { yang sah; Memfasilitasi keinginan para pihak yang bersengketa dan } \\
\text { menawarkan solusi untuk mencapai kata mufakat }\end{array}$ \\
\hline 4. & Jawa Barat & $\begin{array}{l}\text { Wewenang untuk mengeksekusi atau memonitoring, serta menentukan } \\
\text { honorarium mediator; Diberikan kewenangan dengan payung hukum } \\
\text { yang dapat mengikat para pihak apabila ada putusan mediasi yang } \\
\text { sepakat untuk saling bermusyawarah; Wewenang mempimpin mediasi, } \\
\text { mendorong para pihak untuk menyampaikan permasalahan secara } \\
\text { terbuka dan membantu para pihak mencapai titik temu; Melakukan } \\
\text { diagnosis/analisa: sengketa/konflik, masalah dan kepentingan para pihak; } \\
\text { Menyusun agenda; Memperlancar dan mengendalikan komunikasi pihak } \\
\text { yang bersengketa; Melatih para pihak dalam proses tawar-menawar; } \\
\text { Membantu para pihak menyampaikan opsi-opsinya; dan Menyampaikan } \\
\text { opsi-opsi/alternative penyelesaian masalah }\end{array}$ \\
\hline 5. & $\begin{array}{l}\text { Nusa Tenggara } \\
\text { Barat }\end{array}$ & $\begin{array}{l}\text { Memaparkan permasalahan, mengurai benang permasalahan, } \\
\text { melaksanakan kaukus, menawarkan alternatif penyelesaian } \\
\text { permasalahan, menawarkan perdamaian; mendengar, mencatat dan } \\
\text { mengajukan pertanyaan serta menjadi penengah/penetral kemudian } \\
\text { memberikan solusi/saran kepada para pihak; memimpin jalannya mediasi } \\
\text { dan memberikan kesempatan kepada pra pihak untuk menyampaikan } \\
\text { bukti-bukti yang terkait dengan obyek sengketa }\end{array}$ \\
\hline
\end{tabular}


peraturan perundang-undangan, lisensi ini dianggap oleh sebagian besar responden dapat menunjang pelaksanaan tugas dari seorang mediator yang dapat dilihat pada tabel 5.11. Lisensi diatur dalam perundanganundangan.
Dengan memahami hak dan kewajiban yang dimiliki olehnya, tentunya mediator dapat bekerja dengan lebih optimal terlebih lagi jika hak dan kewajiban tersebut tertuang dalam sebuah peraturan karena dengan demikian selain lebih mengikat juga dapat memberikan motivasi bagi mediator.

\section{TABEL 5.10. HAK DAN KEWAJIBAN MEDIATOR}

\section{WILAYAH \\ NO PENELITIAN}

1. Maluku

2. Lampung

3. Kalimantan Selatan

4. Jawa Barat

5. Nusa Tenggara Barat

\section{HAK DAN KEWAJIBAN MEDIATOR}

Haknya adalah meminta, mengundang dan menangguhkan mediasi apabila dianggap perlu; Sebagai penentu terhadap suatu kasus untuk dapat dilaksanakan secara berkelanjutan atau tidak

Kewajibannya adalah mengarahkan kegiatan mediasi; menjadi fasilitator Haknya untuk memutuskan hasil dari sengketa

Kewajiban penengah, memediasi/memfasilitasi para pihak yang bersengketa Menjamin seluruh pihak memahami proses yang akan ditempuh, prosedur, peranan mediator dan hubungan para pihak dan mediator.

Mediator wajib menyelenggarakan proses mediasi sesuai dengan prinsip penentuan diri sendiri atau para pihak; Mediator wajib memberitahu para pihak bahwa semua bentuk penyelesaian keputusan yang diambil dalam proses mediasi memerlukan persetujuan para pihak; Mediator wajib menjelaskan pengertian dan prosedur mediasi, pengertian kaukus dalam proses mediasi serta peran mediator; Mediator wajib menghormati hak para pihak, seperti hak konsultasi dengan penasehat hukum atau para ahli dan hak keluar dari proses mediasi; Mediator wajib menghormati hak para pihak seperti hak konsultasi dengan penasehat hukum atau para ahli dan hak keluar dari proses mediasi; Mediator wajib menghindari penggunaan ancaman, tekanan, atau intimidasi dan paksaan terhadap salah satu atau kedua belah pihak untuk membuat suatu keputusan; Mediator wajib menjaga kerahasiaan informasi yang terungkap di dalam proses mediasi; Mediator wajib memusnahkan catatan - catatan dalam proses mediasi, setelah berakhirnya proses mediasi

Hak menetapkan jadwal mediasi antara para pihak sampai ditemukan/ ditetapkan kesimpulan hasil dari mediasi tersebut; meneliti hubungan hukum/kepentingan para pihak serta kewajiban untuk tetap netral; menyampaikan ide-ide untuk membujuk para pihak untuk saling berdamai; menyampaikan opsi/alternatif penyelesaian masalah pertanahan dan (idealnya) mendapat honorarium Kewajibannya tidak memihak kepada salah satu pihak; mengendalikan proses mediasi agar dapat dicapai kesepakatan dan agar tidak terjadi pihak yang lebih kuat menekan pihak yang lemah

Hak mediator: melakukan kaukus, melakukan pendekatan, melakukan pengkajian kasus; menggali informasi terkait permasalahan yang terjadi dari para pihak; Menjadi pimpinan mediasi; meminta keterangan; mengundang ahli

Kewajiban mediator: membuat berita acara kesepakatan; memberikan saran atau alternatif dalam menyelesaikan masalah; mencari informasi dan melihat/memeriksa alat bukti para pihak; mendorong, menelusuri dan menggali kepentingan para pihak, mencari berbagai pilihan penyelesaian, merumuskan kesepakatan, memeriksa 
Mengenai kewajiban mediator, Ketua MA RI telah mengeluarkan Pedoman Perilaku Mediator, yang ditetapkan pada tanggal 11 Pebruari 2010, dalam bab II pasal 4 bahwa 1) mediator wajib menyelenggarakan proses mediasi sesuai dengan prinsip penentuan diri sendiri oleh para pihak, 2) mediator wajib memberitahu para pihak pada pertemuan lengkap pertama bahwa semua bentuk keputusan atau penyelesaian yang diambil dalam proses mediasi memerlukan persetujuan para pihak, 3) mediator wajib menjelaskan kepada para pihak pada pertemuan lengkap pertama tentang pengertian dan prosedur mediasi, pengertian kaukus dalam proses mediasi serta peran mediator, 4) mediator wajib menghormati para pihak, antara lain hak untuk konsultasi dengan penasehat hukumnya atau para ahli atau hak untuk keluar dari proses mediasi, 5) mediator wajib menghindari penggunaan ancaman, tekanan atau intimidasi dan paksaan terhadap salah satu atau kedua belah pihak untuk membuat keputusan, 6) mediator wajib menjaga kerahasiaan informasi yang terungkap di dalam proses mediasi, 7) mediator wajib memusnahkan catatan-catatan dalam proses mediasi setelah berakhirnya proses mediasi.
Berkaitan dengan point kewajiban mediator di atas, tentunya agak berbeda dengan kewajiban mediator atau dalam hal ini fasilitator di BPN karena untuk point 7 justru catatan itu dapat menjadi alat bukti penting dari proses mediasi yang akan dituangkan dalam suatu berita acara mediasi atau berita acara kesepakatan/perdamaian, demikian juga untuk point 4 justru diharapkan yang terlibat dalam proses mediasi hanya para pihak yang bersengketa saja.

Penelitian lapangan memperoleh masukan dari responden mengenai perlunya diberikan lisensi terhadap mediator yang diatur dalam peraturan perundang-undangan, lisensi ini dianggap oleh sebagian besar responden dapat menunjang pelaksanaan tugas dari seorang mediator yang dapat dilihat pada tabel 5.11. Lisensi diatur dalam perundangan-undangan.

Hasil penelitian menunjukkan terjadi perbedaan persepsi mengenai permasalahan apa saja yang dapat dimediasi, sebagaimana tampak pada tabel 5.12 Masalah yang dapat dimediasi.

\section{TABEL 5.11. LISENSI DIATUR DALAM PERUNDANGAN-UNDANGAN}

\begin{tabular}{|c|c|c|c|c|}
\hline NO & $\begin{array}{l}\text { WILAYAH } \\
\text { PENELITIAN }\end{array}$ & $\begin{array}{l}\text { JUMLAH } \\
\text { SAMPEL }\end{array}$ & $\begin{array}{l}\text { LISENSI DIATUR DALAM } \\
\text { PERUNDANGAN-UNDANGAN }\end{array}$ & PERSENTASE \\
\hline 1. & Maluku & 4 (1 kanwil, 3 kantah) & Semua berpendapat perlu & $100 \%$ \\
\hline 2. & Lampung & 5 (1 kanwil, 4 kantah) & Semua berpendapat perlu & $100 \%$ \\
\hline 3. & $\begin{array}{l}\text { Kalimantan } \\
\text { Selatan }\end{array}$ & 6 (1 kanwil, 5 kantah) & $\begin{array}{l}4 \text { berpendapat perlu: } \\
2 \text { tidak menjawab }\end{array}$ & $67 \%: 33 \%$ \\
\hline 4. & Jawa Barat & 5 (1 kanwil, 4 kantah) & $\begin{array}{l}4 \text { berpendapat perlu : } \\
1 \text { tidak menjawab }\end{array}$ & $80 \%: 20 \%$ \\
\hline 5. & $\begin{array}{l}\text { Nusa Tenggara } \\
\text { Barat }\end{array}$ & 6 (1 kanwil, 5 kantah) & $\begin{array}{l}5 \text { berpendapat perlu: } \\
1 \text { berpendapat tidak perlu }\end{array}$ & $83 \%: 17 \%$ \\
\hline
\end{tabular}




\section{TABEL 5.12. MASALAH YANG DAPAT DIMEDIASI}

\begin{tabular}{|c|c|c|c|c|}
\hline NO & $\begin{array}{l}\text { WILAYAH } \\
\text { PENELITIAN }\end{array}$ & $\begin{array}{l}\text { JUMLAH } \\
\text { SAMPEL }\end{array}$ & $\begin{array}{l}\text { MASALAH YANG } \\
\text { DAPAT DIMEDIASI }\end{array}$ & PERSENTASE \\
\hline 1. & Maluku & 4 (1 kanwil, 3 kantah) & $\begin{array}{l}\text { Semua berpendapat tidak } \\
\text { semua permasalahan dapat } \\
\text { dimediasi }\end{array}$ & $100 \%$ \\
\hline 2. & Lampung & 5 (1 kanwil, 4 kantah) & $\begin{array}{l}2 \text { berpendapat semua bisa } \\
\text { dimediasi : } 3 \text { berpendapat tidak } \\
\text { semua bisa dimediasi }\end{array}$ & $40 \%: 60 \%$ \\
\hline 3. & $\begin{array}{l}\text { Kalimantan } \\
\text { Selatan }\end{array}$ & 6 (1 kanwil, 5 kantah) & $\begin{array}{l}1 \text { berpendapat semua bisa } \\
\text { dimediasi : } 1 \text { berpendapat tidak } \\
\text { semua bisa : } 4 \text { tidak menjawab }\end{array}$ & $\begin{array}{c}17 \%: 17 \%: \\
66 \%\end{array}$ \\
\hline 4. & Jawa Barat & 5 (1 kanwil, 4 kantah) & $\begin{array}{l}1 \text { berpendapat semua bisa } \\
\text { dimediasi : } 4 \text { berpendapat tidak } \\
\text { semua bisa }\end{array}$ & $20 \%: 80 \%$ \\
\hline 5. & $\begin{array}{l}\text { Nusa Tenggara } \\
\text { Barat }\end{array}$ & 6 (1 kanwil, 5 kantah) & $\begin{array}{l}1 \text { berpendapat semua bisa : } 5 \\
\text { berpendapat tidak semua bisa }\end{array}$ & $17 \%: 84 \%$ \\
\hline
\end{tabular}

Sumber: Hasil Pengumpulan Data, 2013

Adanya perbedaan persepsi dari responden ini menunjukkan belum ada kesamaan dalam memandang permasalahan yang dapat dimediasi, beberapa responden yang berpendapat bahwa tidak semua permasalahan dapat dimediasikan menyatakan bahwa permasalahan yang sedang berlangsung di pengadilan atau persoalan pidana tentu tidak dapat dimediasikan.

Dari beberapa ketentuan peraturan perundang-undangan antara lain pasal 30 (ayat2) UU No. 23 tahun 1997 tentang Pengelolaan Lingkungan Hidup menyebutkan bahwa sengketa penyelesaian di luar Pengadilan tidak berlaku terhadap tindak pidana di luar Pengadilan. Kemudian pasal 75 (ayat 1) UU No. 41 tahun 1999 tentang Kehutanan sebagaimana dirubah dengan Undang-Undang No. 19 tahun 2004 menyatakan penyelesaian sengketa kehutanan di luar Pengadilan tidak berlaku terhadap tindak pidana sebagaimana diatur dalam UU Kehutanan tersebut.

Meski demikian secara teoritis, terbuka kemungkinan untuk menyelesaikan tindak pidana tertentu melalui proses penyelesaian di luar Pengadilan. Kemungkinan hal ini dikarenakan sifat sanksi pidana sebagai ultimum remedium. Konsekuensi dari sifat atau ciri ini, bilamana sarana hukum lainnya seperti perdata atau administrasi bisa atau lebih baik digunakan, maka hukum atau sanksi pidana tidak perlu digunakan. Atau dengan kata lain, bila tidak perlu sekali jangan menggunakan pidana sebagai sarana ${ }^{3}$.

Garry Goodpaster berpendapat mediasi tidak selalu dapat diterapkan terhadap suatu sengketa, atau tidak selalu diperlukan untuk menyelesaikan semua persoalan dalam sengketa tertentu. Mediasi akan berhasil dan berfungsi dengan baik bilamana sesuai dengan syarat-syarat, antara lain para pihak mempunyai kekuatan tawar menawar yang sebanding, terdapat persoalan yang memungkinkan terjadinya pertukaran (trades off), terdapat urgensi atau batas waktu untuk menyelesaikan. ${ }^{4}$

3. Soedarto, Hukum dan Hukum Pidana, Alumni, Bandung, 1977.

4. Garry Goodpaster, Tinjauan Terhadap Penyelesaian Sengketa, Ghalia Indonesia, Jakarta, 1995 
Mediator dalam pelaksanaan mediasi di BPN tentunya dilaksanakan oleh pejabat BPN, responden penelitian berpendapat bahwa sebaiknya seorang mediator adalah pihak yang ditunjuk/telah disertipikat, secara terperinci tampak sebagaimana tabel 5.13. Yang dapat menjadi mediator. mediasi sesuai dengan tugas dan fungsinya, sehingga sertipikat bukanlah keharusan. Hal yang sama juga berlaku di Pengadilan, jika dalam wilayah pengadilan yang bersangkutan tidak ada mediator yang bersertifikat, semua hakim pada pengadilan yang bersangkutan dapat ditempatkan dalam daftar mediator.

\section{TABEL 5.13. YANG DAPAT MENJADI MEDIATOR}

\begin{tabular}{|l|l|l|}
\hline NO & $\begin{array}{c}\text { WILAYAH } \\
\text { PENELITIAN }\end{array}$ & \multicolumn{1}{c|}{ YANG DAPAT JADI MEDIATOR } \\
\hline 1. & Maluku & $\begin{array}{l}\text { Orang yang memiliki pengetahuan di bidang pertanahan terutama dari } \\
\text { bidang/seksi SKP, namun melihat kompleksitasnya semua pejabat dari } \\
\text { seksi lain dapat pula ditunjuk }\end{array}$ \\
\hline 2. & Lampung & $\begin{array}{l}\text { Dapat dilakukan oleh siapa saja asalkan orang yang memiliki } \\
\text { pengetahuan di bidang pertanahan terutama dari bidang/seksi SKP }\end{array}$ \\
\hline 3. & $\begin{array}{l}\text { Kalimantan } \\
\text { Selatan }\end{array}$ & $\begin{array}{l}\text { Semuanya dapat menjadi mediator, namun terutama dari bidang/seksi } \\
\text { SKP }\end{array}$ \\
\hline 4. & Jawa Barat & $\begin{array}{l}\text { Untuk menjadi mediator haruslah orang yang independen artinya secara } \\
\text { khusus ditunjuk karena penyelesaiannya dan tidak ada keberpihakan, } \\
\text { maka yang penting adalah kemauan dan kemampuannya untuk menjadi } \\
\text { mediator }\end{array}$ \\
\hline 5. & $\begin{array}{l}\text { Nusa Tenggara } \\
\text { Barat }\end{array}$ & $\begin{array}{l}\text { Pihak yang ditunjuk/telah bersertifikat secara khusus memiliki keahlian } \\
\text { terutamaa dari bidang/seksi SKP berdasarkan tupoksi yang melekat } \\
\text { padanya }\end{array}$ \\
\hline
\end{tabular}

Sumber: Hasil Pengumpulan Data, 2013

Dari tabel diatas dapat disimpulkan bahwa para responden berpendapat utamanya yang dijadikan mediator adalah orang yang mempunyai kemampuan di bidang hukum dan teknis pertanahan namun tentu sesuai dengan tupoksi yang melekat maka harusnya diutamakan dari bidang/seksi Penanganan Sengketa Konflik Dan Perkara Pertanahan.

Terkait dengan peraturan yang menyebutkan bahwa setiap mediator harus mendapatkan sertifikasi dari lembaga yang telah ditunjuk dan diakreditasi oleh Mahkamah Agung (MA) setelah mengikuti pelatihan oleh lembaga tersebut, maka mediator yang menangani kasus pertanahan di BPN melakukan fungsi
4. KEPASTIAN HUKUM TERHADAP HALHAL YANG DISEPAKATI PARA PIHAK DALAM PROSES MEDIASI

Responden dalam penelitian berpendapat bahwa BAK yang dicapai para pihak sebaiknya didaftarkan di pengadilan atau dibuat dihadapan notaris, bahkan ada yang berpendapat agar keduanya dilaksanakan baik dibuat dihadapan notaris maupun didaftarkan di pengadilan supaya lebih mengikat, sebagaimana tampak pada tabel 5.14 Pembuatan Berita Acara Perdamaian (BAP).

Tabel 5.14 menunjukkan bahwa Berita Acara Perdamaian yang dibuat di hadapan Notaris 
TABEL 5.14. PEMBUATAN BERITA ACARA PERDAMAIAN (BAP)

\begin{tabular}{|c|c|c|c|c|c|c|}
\hline NO. & $\begin{array}{l}\text { WILAYAH } \\
\text { PENELITIAN }\end{array}$ & $\begin{array}{l}\text { JUMLAH } \\
\text { SAMPEL }\end{array}$ & $\begin{array}{l}\text { DIBUAT DI } \\
\text { HADAPAN } \\
\text { NOTARIS }\end{array}$ & $\begin{array}{l}\text { DIDAFTARKAN } \\
\text { DI PENGADILAN }\end{array}$ & $\begin{array}{c}\text { DILAKUKAN } \\
\text { KEDUANYA } \\
\text { (NOTARIS + } \\
\text { DIDAFTARKAN) }\end{array}$ & $\begin{array}{c}\text { TIDAK } \\
\text { MENJAWAB/ } \\
\text { OPSI } \\
\text { LAINNYA } \\
\end{array}$ \\
\hline 1. & Maluku & $\begin{array}{l}4 \text { (1 kanwil, } \\
3 \text { kantah) }\end{array}$ & - & 1 & 1 & 2 \\
\hline 2. & Lampung & $\begin{array}{l}5 \text { (1 kanwil, } \\
4 \text { kantah) }\end{array}$ & - & 1 & 1 & 3 \\
\hline 3. & $\begin{array}{l}\text { Kalimantan } \\
\text { Selatan }\end{array}$ & $\begin{array}{c}6 \text { (1 kanwil, } \\
5 \text { kantah) }\end{array}$ & 3 & - & - & 3 \\
\hline 4. & Jawa Barat & $\begin{array}{l}5 \text { (1 kanwil, } \\
4 \text { kantah) }\end{array}$ & 3 & 1 & 1 & - \\
\hline 5. & $\begin{array}{l}\text { Nusa Tenggara } \\
\text { Barat }\end{array}$ & 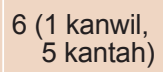 & - & 1 & - & 5 \\
\hline
\end{tabular}

Sumber: Hasil Pengumpulan Data, 2013

ditemukan di Provinsi Kalimantan Selatan dan Jawa Barat, yang di daftarkan di pengadilan ditemukan di Provinsi Maluku, lampung, Jawa Barat dan Nusa Tenggara Barat.

Usulan selain dibuatkan secara notaril/ didaftarkan di pengadilan yang didapat dari penelitian adalah cukup dibuat di kantor BPN dan ditandatangani oleh para pihak, saksisaksi dan diketahui oleh pejabat BPN.

Responden lebih banyak yang menyatakan bahwa BAK yang sudah disetujui para pihak lebih tepat dibuatkan akta notariil di hadapan notaris, sebagaimana tampak pada tabel

\section{TABEL 5.15. PENDAFTARAN BERITA ACARA PERDAMAIAN (BAP)}

\begin{tabular}{|c|c|c|c|c|c|c|}
\hline NO. & $\begin{array}{l}\text { WILAYAH } \\
\text { PENELITIAN }\end{array}$ & $\begin{array}{l}\text { JUMLAH } \\
\text { SAMPEL }\end{array}$ & NOTARIS & $\begin{array}{l}\text { DIDAFTARKAN } \\
\text { DI PENGADILAN }\end{array}$ & KEDUANYA & $\begin{array}{c}\text { TIDAK } \\
\text { MENJAWAE }\end{array}$ \\
\hline 1. & Maluku & $\begin{array}{l}4 \text { (1 kanwil, } \\
3 \text { kantah) }\end{array}$ & 1 & 1 & 2 & - \\
\hline 2. & Lampung & $\begin{array}{l}5 \text { (1 kanwil, } \\
4 \text { kantah) }\end{array}$ & 2 & 1 & - & 2 \\
\hline 3. & $\begin{array}{l}\text { Kalimantan } \\
\text { Selatan }\end{array}$ & $\begin{array}{r}6 \text { (1 kanwil, } \\
5 \text { kantah) }\end{array}$ & 3 & 1 & - & 2 \\
\hline 4. & Jawa Barat & $\begin{array}{l}5 \text { (1 kanwil, } \\
4 \text { kantah) }\end{array}$ & 2 & 1 & 2 & - \\
\hline 5. & $\begin{array}{l}\text { Nusa Tenggara } \\
\text { Barat }\end{array}$ & $\begin{array}{l}6 \text { (1 kanwil, } \\
5 \text { kantah) }\end{array}$ & 4 & 1 & 1 & - \\
\hline
\end{tabular}

Sumber: Hasil Pengumpulan Data, 2013 
5.15 Pendaftaran Berita Acara Perdamaian (BAP).

Responden yang berpendapat lebih tepat dibuatkan akta notariil di hadapan notaris beralasan karena permasalahan tersebut selama sebelum beracara di pengadilan masih merupakan ranah privat (belum pada ranah beracara), sehingga lebih baik dilakukan dihadapan notaries, dengan demikian merupakan akte otentik.

Pada dasarnya surat perjanjian perdamaian atau yang biasa disebut berita acara perdamaian/BAK tidak harus dibuat dengan akta notariil, dapat dengan akta bawah tangan, hanya saja akta bawah tangan masih dapat disangkal dan baru mempunyai kekuatan pembuktian yang sempurna apabila diakui oleh kedua belah pihak atau dikuatkan lagi dengan alat-alat bukti lainnya karena akta bawah tangan merupakan permulaan bukti tertulis (begin van schriftelijk).

Hasil akhir dari mediasi adalah Berita Acara Kesepakatan (BAK) yang dapat berupa perdamaian merupakan kesepakatan dari para pihak, karena berupa kesepakatan seharusnya tidak ada lagi wanprestasi terhadap BAK, karena kesepakatan dilakukan bersama-sama oleh para pihak, secara sadar dan tanpa tekanan dalam musyawarah untuk mufakat bahkan dalam hal ini mediasi dilakukan dengan mediator.

Namun yang terjadi dalam praktik seringkali berbeda dengan teori yang ada, dalam penelitian lapangan yang dilakukan data lapangan menunjukkan di beberapa tempat terjadi pelanggaran terhadap Berita Acara Kesepakatan yang telah dicapai, dapat dilihat pada tabel 5.16. Pelanggaran Berita Acara Perdamaian (BAK).

TABEL 5.16. PELANGGARAN BERITA ACARA PERDAMAIAN (BAK)

\begin{tabular}{|c|c|c|c|c|c|}
\hline No. & $\begin{array}{l}\text { WILAYAH } \\
\text { PENELITIAN }\end{array}$ & $\begin{array}{l}\text { JUMLAH } \\
\text { SAMPEL }\end{array}$ & $\begin{array}{c}\text { BELUM ADA } \\
\text { PELANGGARAN BAK }\end{array}$ & $\begin{array}{l}\text { ADA PELANGGARAN } \\
\text { TERHADAP BAK }\end{array}$ & $\begin{array}{c}\text { TIDAK } \\
\text { MENJAWAB }\end{array}$ \\
\hline 1. & Maluku & $\begin{array}{l}4 \text { (1 kanwil, } \\
3 \text { kantah) }\end{array}$ & - & 4 & - \\
\hline 2. & Lampung & $\begin{array}{l}5 \text { (1 kanwil, } \\
4 \text { kantah) }\end{array}$ & 4 & - & 1 \\
\hline 3. & $\begin{array}{l}\text { Kalimantan } \\
\text { Selatan }\end{array}$ & $\begin{array}{l}6 \text { (1 kanwil, } \\
5 \text { kantah) }\end{array}$ & 3 & - & 3 \\
\hline 4. & Jawa Barat & $\begin{array}{l}5 \text { (1 kanwil, } \\
4 \text { kantah) }\end{array}$ & 3 & 2 & - \\
\hline 5. & $\begin{array}{l}\text { Nusa Tenggara } \\
\text { Barat }\end{array}$ & $\begin{array}{c}6 \text { (1 kanwil, } \\
5 \text { kantah) }\end{array}$ & 3 & 2 & 1 \\
\hline
\end{tabular}

Sumber: Hasil Pengumpulan Data, 2013 
Sebagaimana tampak dalam tabel 5.16, ternyata walaupun telah terjadi kesepakatan yang dituangkan dalam Berita Acara Perdamaian dan seharusnya di taati oleh para pihak yang bersepakat namun pada prakteknya masih terjadi pelanggaran pada Berita Acara Perdamaian yang merupakan hasil mediasi.

Yang menarik kasus di Kota Cimahi, dimana Berita Acara perdamaian digugat di Pengadilan TUN setempat. Obyek gugatan dalam sengketa TUN adalah berupa Keputusan TUN (beschikking). Sehingga sangat tidak tepat Berita Acara Perdamaian di gugat di PTUN.

Berita Acara Perdamaian/BAK tersebut merupakan kesepakatan bersama yang dilakukan oleh para pihak dengan tujuan dan itikad baik untuk membuat suatu perjanjian. Perdamaian pada hakikatnya dapat saja dibuat para pihak dihadapan atau oleh hakim yang memeriksa perkara, juga perdamaian dapat dibuat oleh para pihak diluar pengadilan dan selanjutnya di bawa ke pengadilan yang bersangkutan untuk dikukuhkan.

Perdamaian dapat dilakukan secara bebas oleh para pihak namun undang-undang telah mengatur berbagai jenis perdamaian yang tidak boleh dilakukan oleh para pihak.

Perdamaian yang tidak diperbolehkan adalah:

a. Perdamaian tentang telah terjadinya kekhilafan mengenai orang yang bersangkutan atau pokok perkara ;

b. Perdamaian yang telah dilakukan dengan cara penipuan atau paksaan ;

c. Perdamaian mengenai kekeliruan mengenai duduk perkara tentang suatu alas hak yang batal, kecuali bila para pihak telah mengadakan perdamaian tentang kebatalan itu dengan pernyataan tegas ;

d. Perdamaian yang diadakan atas dasar surat-surat yang kemudian dinyatakan palsu ;

e. Perdamaian mengenai sengketa yang sudah diakhiri dengan suatu keputusan hakim yang telah memperoleh kekuatan hukum yang pasti, namun tidak diketahui oleh para pihak atau salah satu pihak. Akan tetapi jika keputusan yang tidak diketahui itu masih dimintakan banding maka perdamaian mengenai sengketa yang bersangkutan adalah sah ;

f. Perdamaian hanya mengenai suatu urusan, sedangkan dari surat-surat yang ditemukan kemudian ternyata salah satu pihak tidak berhak atas hal itu.

Apabila keenam hal itu dilakukan maka perdamaian itu dapat dimintakan pembatalan kepada pengadilan. ${ }^{5}$

Pelanggaran BAK terjadi pada dua propinsi dari lima propinsi yang menjadi sampel penelitian lapangan, yakni pada Propinsi Jawa Barat dan Propinsi Nusa Tenggara Barat. Pelanggaran BAK di Propinsi Jawa Barat terjadi di Kota Cimahi, sebagaimana disebutkan dalam kuesioner yang diisi oleh Kepala Kantor/Kepala Seksi Penanganan Sengketa, Konflik dan Perkara Pertanahan menyatakan ada walaupun kecil sekali. Di Propinsi Nusa Tenggara Barat pelanggaran terhadap BAK malah terjadi di dua lokasi yakni di Kabupaten Lombok Tengah dan Kabupaten Lombok Timur. Menurut kuesioner yang diisi oleh Kepala Kantor/Kepala Seksi Penanganan Sengketa, Konflik dan Perkara Pertanahan Kabupaten Lombok Tengah, pelanggaran BAK seringkali terjadi pada tanah-tanah yang memiliki

5. Salim, Hukum Kontrak, Teori dan Teknis Penyusunan Kontrak, (Jakarta : Sinar Grafika, 2006), hal. 94 
nilai jual tinggi. Kepala Seksi Penanganan Sengketa, Konflik dan Perkara Pertanahan Kabupaten Lombok Timur menyatakan bahwa pelanggaran terhadap BAK di Lombok Timur bahkan mencapai angka 30\%.

Penelitian menunjukkan pihak Kantor Pertanahan masih berupaya untuk melakukan sesuatu ketika salah satu pihak melakukan pelanggaran terhadap kesepakatan yang dicapai, sebagaimana tampak pada tabel 5.17. Tindakan.
Upaya yang masih dilakukan oleh Kantor Pertanahan ternyata tidak seragam dan bermacam-macam tergantung kebijakan dari pejabat yang menangani. Kanwil Provinsi Maluku dan Kantor Pertanahan Kota Ambon, membuat rekomendasi agar para pihak melakukan jalur hukum melalui lembaga pengadilan jika terjadi pelanggaran terhadap BAK yang dilakukan oleh para pihak.

\section{TABEL 5.17. TINDAKAN}

\begin{tabular}{|c|c|c|c|c|c|}
\hline NO. & $\begin{array}{c}\text { WILAYAH } \\
\text { PENELITIAN }\end{array}$ & $\begin{array}{l}\text { JUMLAH } \\
\text { SAMPEL }\end{array}$ & $\begin{array}{c}\text { MELAKUKAN UPAYA } \\
\text { TERTENTU }\end{array}$ & $\begin{array}{l}\text { TIDAK MELAKUKAN } \\
\text { UPAYA APAPUN }\end{array}$ & $\begin{array}{c}\text { TIDAK } \\
\text { MENJAWAB }\end{array}$ \\
\hline 1. & Maluku & $\begin{array}{l}4 \text { (1 kanwil, } \\
3 \text { kantah) }\end{array}$ & 2 & - & 3 \\
\hline 2. & Lampung & $\begin{array}{l}5 \text { (1 kanwil, } \\
4 \text { kantah) }\end{array}$ & 4 & - & 1 \\
\hline 3. & $\begin{array}{l}\text { Kalimantan } \\
\text { Selatan }\end{array}$ & $\begin{array}{r}6 \text { (1 kanwil, } \\
5 \text { kantah) }\end{array}$ & - & 2 & 4 \\
\hline 4. & Jawa Barat & $\begin{array}{l}5 \text { (1 kanwil, } \\
4 \text { kantah) }\end{array}$ & 5 & - & - \\
\hline 5. & $\begin{array}{l}\text { Nusa Tenggara } \\
\text { Barat }\end{array}$ & $\begin{array}{l}6 \text { (1 kanwil, } \\
5 \text { kantah) }\end{array}$ & 2 & 1 & 3 \\
\hline
\end{tabular}

Sumber: Hasil Pengumpulan Data, 2013 
Di Kanwil Provinsi Lampung, Kantor Pertanahan Tulang Bawang dan Kantor Pertanahan Tanggamus jika terjadi pelanggaran terhadap BAK yang dilakukan adalah memberikan pengertian mengenai mediasi yang sudah dilakukan dan jika tetap tidak dilanggar maka akan menyarankan agar para pihak menempuh jalur hukum melalui lembaga pengadilan.

Di Provinsi Jawa Barat, Kanwil berpendapat sebagaimana disebutkan dalam kuesioner bahwa tidak ada yang dilakukan karena tidak berdaya melakukan apapun. Kantor Pertanahan Kota Bandung akan mengundang kembali para pihak, apabila setelah diundang para pihak tidak tercapai kesepakatan Kantor Pertanahan Kota Bandung akan menyarankan agar menempuh jalur hukum. Lain halnya yang dilakukan oleh Kantor Pertanahan Kota Cimahi, yaitu memberikan pemahaman kepada pihak yang ingkar/melanggar BAK tersebut dengan menjelaskan konsekwensi dari sikap yang tidak konsisten. Kantor Pertanahan Kota Depok, menyerahkan kembali sepenuhnya kepada para pihak karena. Kantor Pertanahan Bandung Barat melakukan pencatatan terlebih dahulu pelanggaran-pelanggaran yang ada kemudian melaporkan kepada pimpinan (Kanwil/ BPN RI) dan mempersilahkan kepada para pihak yang bersengketa untuk melanjutkan permasalahannya di pengadilan.

Di Provinsi Nusa Tenggara Barat, Kanwil tidak menjawab mengenai upaya apa yang seharusnya dilakukan. Kantor Pertanahan Kota Mataram berpendapat apabila terjadi pelanggaran terhadap BAK maka tidak ada kewenangan BPN terhadap hal tersebut.
Kantor Pertanahan Lombok Tengah dan Lombok Timur menyarankan para pihak agar melanjutkan permasalahannya ke pengadilan. Tidak dilaksanakannya BAK oleh para pihak tentu menjadi permasalahan tersendiri, dalam penelitian lapangan yang dilakukan juga menampung usulan dari kanwil/kantah mengenai upaya apa yang seharusnya dilakukan agar BAK tersebut lebih dipatuhi.

Penelitian di Provinsi Maluku, Kantor Pertanahan Kota Ambon menyarankan agar dalam mediasi diatur mengenai sanksi yang diberlakukan apabila ada salah satu pihak yang melanggar BAK. Kantor Pertanahan Maluku Tenggara menyarankan agar dimintakan penetapan pengadilan.

Penelitian di Provinsi Lampung, kanwil menyarankan agar membuat point-point dalam kesepakatan supaya tidak terjadi interpretasi lain, juga mencantumkan sanksi yang disepakati para pihak bila kesepakatan BAK tidak ditaati, demikian pula Kantor Pertanahan Lampung Tengah, menyarankan agar ada sanksi terhadap pelanggar BAK. Kantor Pertanahan Kabupaten Tulang Bawang menyarankan agar penandatanganan BAK dilakukan di hadapan Notaris, serupa dengan usulan tersebut Kantor Pertanahan Kabupaten Tanggamus menyarankan agar penandatanganan BAK dilakukan di hadapan aparat desa setempat.

Penelitian di Provinsi Kalimantan Selatan, Kanwil memberikan usulan BAK harus didaftarkan di pengadilan untuk memperoleh putusan hukum, sehingga bila ada salah satu pihak ingkar janji, langsung dapat dilaksanakan eksekusi. Usulan yang sama diberikan oleh Kantor Pertanahan 
Kota Banjarmasin. Berbeda dengan usulan tersebut, Kantor Pertanahan Banjar Baru menyarankan agar BAK tersebut dibuatkan akta otentik di hadapan notaris.

Penelitian di Provinsi Jawa Barat, Kanwil menyarankan supaya BAK tersebut selain dibuat dihadapan notaris juga didaftarkan di pengadilan agar lebih mengikat dan ditaati para pihak. Kantor Pertanahan Kota Cimahi menyarankan agar dibuatkan payung hukum yang mengatur mengenai hal tersebut, Kantor Pertanahan Kota Depok memberikan usulan agar BAK tersebut dibuat dihadapan notaris. Kantor Pertanahan Kabupaten bandung Barat memberikan usulan agar BAK mengikat para pihak yang bersengketa atau pihak ketiga, maka BAK perlu didaftarkan di pengadilan agar mempunyai title eksekutorial: "DEMI KEADILAN BERDASARKAN KETUHANAN YANG MAHA ESA". Yang mempunyai kekuatan sama dengan putusan pengadilan yang inkracht.

Penelitian di Provinsi Nusa Tenggara Barat, usulan dari Kanwil, Kantor Pertanahan Kabupaten Lombok Barat, Lombok Timur dan Lombok Utara adalah agar BAK tersebut didaftarkan di pengadilan. Kantor Pertanahan Kota Mataram mengusulkan perlu adanya sanksi apabila Berita Acara Perdamaian dilanggar oleh para pihak.

Dalam rapat pembahasan TOR penelitian, diperoleh informasi bahwa kantor Pertanahan jakarta Selatan membuat akta perdamaian di hadapan Notaris. Cara ini diyakini dapat lebih mengikat para pihak untuk mentaati akta perdamaian.
Berdasarkan ketemtuan pasal 1868 KUHPerdata, yang disebut dengan akta otentik adalah suatu akta yang dibuat dalam bentuk yang ditentukan oleh undang-undang, dibuat oleh atau di hadapan pegawaipegawai umum yang berkuasa untuk itu dan di tempat dimana akta itu di buat. Ada dua golongan akta notaries, pertama, akta perjabat atau acte relass (ambtelijk akten), merupakan akta yang menguraikan secara otentik mengenai suatu tindakan yang dilakukan atau sutau keadaan yang dilihat atau disaksikan oleh pembuat akta itu yakni notaris sendiri dalam menjalankan tugasnya sebagai notaris. Akta yang dibuat sedemikian dan memuat uraian dari apa yang dilihat dan disaksikan, dinamakan akta yang dibuat "oleh" sebagai pejabat umum. Yang termasuk dalam akta ini antara lain adalah berita acara rapat pemegang saham dalam perseroan terbatas dan akta pencatatan harta peninggalan. Kedua, akta yang dibuat " dihadapan " (ten overstan) notaries atau yang dinamakan "akta partij" (partij acten) yaitu akta yang berisikan suatu cerita dari apa yang terjadi karena perbuatan yang dilakukan oleh pihak lain dihadapan notaris, artinya segala sesuatu yang diterangkan atau diceritakan oleh pihak lain yang sengaja datang kepada notaries dituangkan dalam suatu otentik, yang termasuk golongan ini adalah akta jual beli, akta perdamaian di luar pengadilan, akta sewa menyewa dan akta wasiat.

Sebagai suatu akta yang otentik, maka akta notaries memiliki kekuatan pembuktian yang lengkap, apabila gugatan diajukan ke pengadilan hakim dapt mengajukan tuntutan 
serta merta (uit voerbaar bij vooraad) karena akta tersebut mempunyai kekuatan bukti sempurna atau tidak dapat disangkal lagi, isi akta tersebut dianggap benar dan hakim harus mempercayai apa yang ditulis didalamnya. Akta tersebut hanya dapat dilemahkan apabila ada bukti perlawanan yang kuat. ${ }^{6}$

Di dalam Pasal 1858 ayat ( 1 ) Kitab UndangUndang Hukum Perdata, perdamaian yang diadakan para pihak harus dibuatkan dalam bentuk tertulis. Sehingga dapat disimpulkan bahwa bentuk tertulis dari perjanjian perdamaian yang dimaksudkan undangundang adalah bentuk tertulis yang otentik, yaitu yang dibuat di hadapan pejabat yang berwenang dalam hal ini adalah notaris. Perjanjian perdamaian secara tertulis yang dibuat di hadapan notaris ini dapat dijadikan sebagai alat bukti bagi para pihak untuk diajukan kehadapan hakim (pengadilan) karena isi perdamaian itu disamakan dengan putusan hakim yang telah mempunyai kekuatan hukum yang tetap.

Berita Acara Kesepakatan merupakan suatu "perjanjian". Karena merupakan perjanjian maka berlaku sebagai undang-undang bagi para pihak yang telah bersepakat. KUHperdata membedakan perikatan yang lahir dari perjanjian dan perikatan yang lahir dari undang-undang. Apabila atas perjanjian yang disepakati terjadi pelanggaran, maka dapat diajukan gugatan wanprestasi karena ada hubungan kontraktual antara pihak yang menimbulkan kerugian dan pihak yang menderita kerugian. Tujuan gugatan wanprestasi adalah untuk menempatkan penggugat pada posisi seandainya perjanjian tersebut dipenuhi. Wanprestasi dapat berbentuk, a) debitur tidak memenuhi prestasi pada waktunya (terlambat); b) debitur tidak memenuhi prestasi sama sekali; c) debitur memenuhi prestasi dengan tidak baik (tidak sesuai dengan yang diperjanjikan.

Untuk lebih memberikan kekuatan mengikat pada Berita Acara Kesepakatan atau Berita Acara Perdamaian sehingga bisa langsung dilaksanakan eksekusi maka pencantuman Titel Eksekutorial di dalam BAK dirasa perlu oleh sebagian besar responden penelitian, hal tersebut dapat dilihat sebagaimana pada tabel 5.18 Usulan Titel Eksekutorial di BAK.

\section{TABEL 5.18. USULAN TITEL EKSEKUTORIAL DI BAK}

\begin{tabular}{|c|c|c|c|c|c|}
\hline NO. & $\begin{array}{l}\text { WILAYAH } \\
\text { PENELITIAN }\end{array}$ & $\begin{array}{l}\text { JUMLAH } \\
\text { SAMPEL }\end{array}$ & $\begin{array}{l}\text { PERLU TITEL } \\
\text { EKSEKUTORIAL }\end{array}$ & $\begin{array}{l}\text { TIDAK PERLU TITEL } \\
\text { EKSEKUTORIAL }\end{array}$ & $\begin{array}{c}\text { TIDAK } \\
\text { MENJAWAB }\end{array}$ \\
\hline 1. & Maluku & $\begin{array}{l}4 \text { (1 kanwil, } \\
3 \text { kantah) }\end{array}$ & 4 & - & - \\
\hline 2. & Lampung & $\begin{array}{l}5 \text { (1 kanwil, } \\
4 \text { kantah) }\end{array}$ & 3 & 1 & 1 \\
\hline 3. & $\begin{array}{l}\text { Kalimantan } \\
\text { Selatan }\end{array}$ & $\begin{array}{l}6 \text { (1 kanwil, } \\
5 \text { kantah) }\end{array}$ & - & 3 & 3 \\
\hline 4. & Jawa Barat & $\begin{array}{l}5 \text { (1 kanwil, } \\
4 \text { kantah) }\end{array}$ & 4 & - & 1 \\
\hline 5. & $\begin{array}{l}\text { Nusa Tenggara } \\
\text { Barat }\end{array}$ & $\begin{array}{l}6 \text { (1 kanwil, } \\
5 \text { kantah) }\end{array}$ & 4 & 2 & - \\
\hline
\end{tabular}

Sumber: Hasil Pengumpulan Data, 2013 
Tabel diatas menunjukkan banyaknya usulan dari responden mengutarakan perlu diberikan title eksekutorial supaya dapat lebih ditaati sehingga memiliki kekuatan eksekusi sebagaimana hak tanggungan.

Titel eksekutorial dimaksud seperti titel eksekutorial yang terdapat dalam sertipikat hak tanggungan yaitu adanya irah-irah tersebut untuk memberikan kekuatan eksekutorial yang sama dengan putusan pengadilan yang sudah mempunyai kekuatan hukum tetap. Untuk pencantuman titel eksekutorial tersebut maka pengaturannya haruslah setingkat Undang-Undang. Dengan pencantuman titel eksekutorial pada berita acara perdamaian atau berita acara kesepakatan maka diharapkan tidak terjadi lagi wanprestasi terhadap kesepakatan/ perdamaian yang telah dilakukan para pihak, sehingga menjamin kepastian hukum bagi pelaksanaan kesepakatan tersebut. 


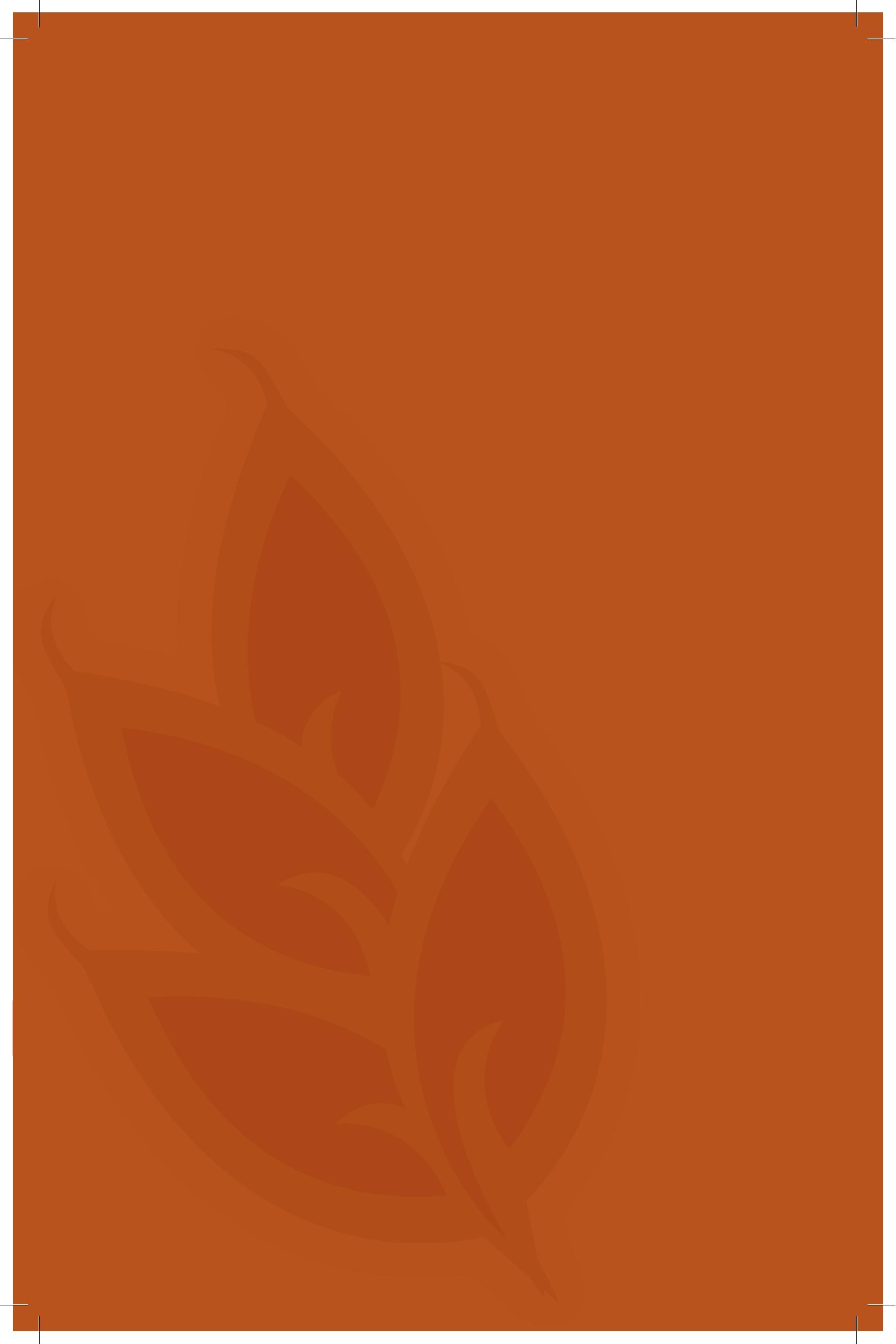




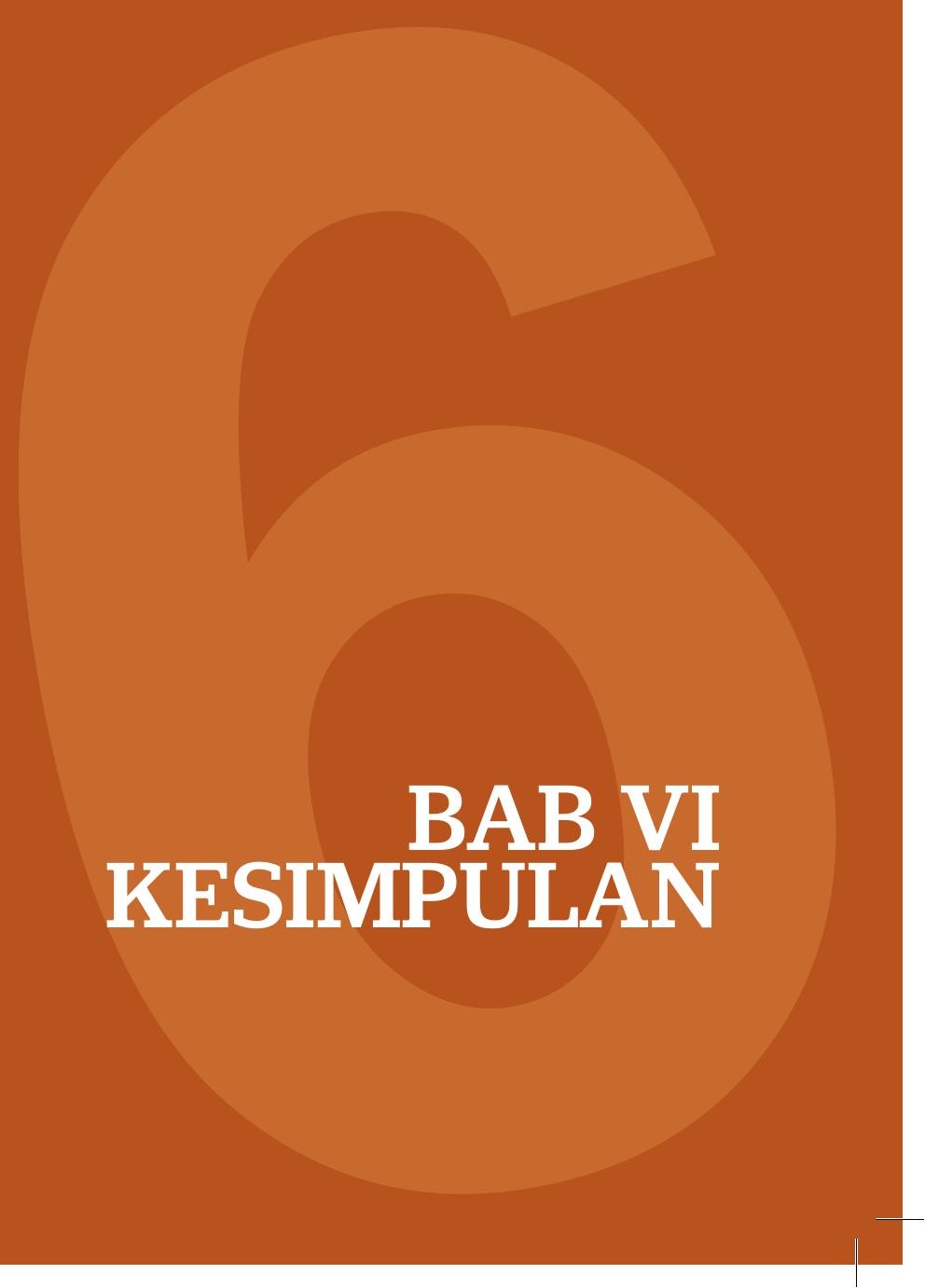




\section{BAB VI KESIMPULAN}

\section{KESIMPULAN}

a. Pelaksanaan mediasi sebagaimana yang diatur dalam Peraturan KBPN No. 3 tahun 2011 Tentang Pengelolaan Pengkajian Dan Penanganan Kasus Pertanahan belum mengatur secara khusus mengenai tahapan kegiatan mediasi, apa saja yang harus dilakukan dan dilarang dilakukan sehingga tidak ada pedoman dalam melakukan kegiatan mediasi sebagaimana yang diatur dalam peraturan sebelumnya dan sudah dinyatakan tidak berlaku dengan Perkaban yang baru. Pengaturan ini penting mengingat ada kemungkinan aparat yang menangani kegiatan mediasi tidak senantiasa paham dengan mediasi, dengan adanya pengaturan mengenai tata cara kerja mediasi maka optimalisasi kegiatan dapat lebih ditingkatkan.

b. Dalam peraturan MA seorang mediator harus mempunyai sertipikat mediator, namun tidak demikian dengan aparat BPN yang melakukan mediasi karena menjalankan tugas dan fungsinya sehingga legitimasinya adalah peraturan organisasi, maka untuk meningkatkan peran mediator atau fasilitator perlu ada lisensi sebagai fasilitator yang intinya memberikan wewenang untuk melakukan tindakan yang diperlukan dalam mediasi, termasuk hak dan kewajiban yang dimiliki.

c. Untuk memberikan kepastian hukum terhadap hal-hal yang disepakati para pihak dalam Berita Acara Kesepakatan/BAK maka dilakukan beberapa cara oleh Kantor Pertanahan, ada yang mendaftarkan BAK tersebut ke Pengadilan sesuai dengan peraturan MA, ada pula yang membuat BAK di hadapan notaris sehingga berlaku sebagai akta notariil, atau bahkan tidak di daftar ke Pengadilan dan tidak dibuat notariil tetapi cukup menggunakan format Berita Acara Perdamaian sebagaimana yang diatur dalam Perkaban, namun cara yang terakhir ini sering diingkari dan tidak ditaati oleh para pihak yang bersengketa sehingga apa yang sudah disepakati dalam Berita Acara Perdamaian/BAK menjadi sia-sia. Penegakan hukum terhadap pelanggaran BAK sulit dilakukan walaupun secara teoritis BAK merupakan perjanjian yang berlaku sebagai undang-undang bagi mereka yang telah bersepakat.

\section{REKOMENDASI}

a. Peraturan KBPN No. 3 tahun 2011 Tentang Pengelolaan Pengkajian Dan Penanganan Kasus Pertanahan perlu ditindak lanjuti dengan petunjuk pelaksanaan yang mengatur secara khusus mengenai kegiatan mediasi.

b. Nomenklatur mediator bagi aparat BPN yang melakukan mediasi sebaiknya dirubah menjadi fasilitator karena BPN sering ikut menjadi pihak dalam sengketa yang sedang di mediasi, sedangkan seorang mediator tidak boleh ikut menjadi pihak dalam sengketa yang di mediasikan.

c. Untuk menjamin kepastian hukum dari berita acara perdamaian/BAK maka dalam BAK perlu dicantumkan titel eksekutorial sehingga mempunyai kekuatan eksekusi terhadap apa yang telah disepakati, adanya pencantuman titel eksekutorial BAK perlu dimasukkan dalam RUU Pertanahan, sehingga BAK yang dilakukan BPN dapat berlaku efektif . 


\section{Daftar Pustaka}

Achmad Ya'kub, dalam Konflik Agraria, Tinjauan Umum Kasus Agraria di Indonesia, Federasi Serikat Petani Indonesia, Jakarta, 2007, hal 20-22

C.S.T. Kansil, Modul Hukum Perdata Termasuk Asas-Asas Hukum Perdata, PT. Pradnya Paramita, Jakarta, 2006

Daud, Alfani, Islam dan Masyarakat Banjar: Deskripsi dan Analisa Kebudayaan Banjar, RajaGrafindo Persada, Jakarta, 1997.

Djubaedah, Neng, 1998, "Pelaksanaan Hukum Kewarisan Islam dalam Masyarakat Muslim di Indonesia Suatu Harapan”, Artikel dalam Mimbar Hukum, No. 40, Tahun IX.

Endriatmo Soetarto dan Moh. Shohibudin, Menegaskan Kembali Keharusan Reforma Agraria sebagai Basis Pembangunan Pertanian dan Pedesaan (Agenda untuk Pemerintahan 20042009), Jurnal Pembaruan Desa dan Agraria, Volume 01/Tahun I/2004, Progam Studi Sosiologi Pedesaaan IPB-Pusat Kajian Agraria IPB-Lapera Indonesia.

Erman Rajagukguk, Arbitrase Dalam Putusan Pengadilan, Chandra Pratama, Jakarta, 2000.

Garry Goodpaster, Tinjauan Terhadap Penyelesaian Sengketa, Ghalia Indonesia, Jakarta, 1995

Gusti Muzainah, Pembagian Harta Warisan Menurut Hukum waris Adat Masyarakat Banjar, Tesis,: UNAIR, Surabaya , 1999, hlm. 59-68.

Hadjon, Philipus M, Pengantar Hukum Administrasi Indonesia, Yogyakarta, Gajah Mada University Press, 1994.

I Nyoman Nurjaya, (2010) Prinsip-Prinsip Pengelolaan Sumber Daya Alam, Keterangan Ahli dalam Persidangan Uji Materi (Judicial Review) Undang-Undang Pengelolaan Wilayah Pesisir dan Pulau-Pulau Kecil di Mahkamah Konstitusi, Jakarta.

John W. Head, Pengantar Umum Hukum Ekonomi, ELIPS, Jakarta, 2002

Joni Emirzon, Alternatif Penyelesaian Sengketa di Luar Pengeadilan (Negoisasi, Mediasi, Konsultasi dan Arbitrase) , PT. Gramedia Pustaka Utama, Jakarta, 2001

Laurence Boulle, Mediation: Principle, process, practice, Butterworths, Sydney, 1996.

Muslih MZ, Mediasi : Pengantar, Teori Dan Praktek, Walisongo Mediation Center, Semarang, 2007

Purwahid, Azas Itikad Baik dan Kepatutan Dalam. Perjanjian, Penerbit : FH. UNDIP, Semarang, 1982. 
Retnowulan Sutantio dan Iskandar Oeripkartawinat, Hukum Acara Perdata dalam Teori dan Praktek, Bandung, CV Mandar Maju, 1997

Riza Yudha Patria, Thesis "Kebijakan Penerapan Hukum Pertanahan Nasional dan Pengaruhnya Terhadap Eksistensi hak Ulayat Di Kabupaten Lampung Barat Provinsi Lampung, 2002.

Salim, Hukum Kontrak, Teori dan Teknis Penyusunan Kontrak, Sinar Grafika, Jakarta, 2006.

Satrio, J. Cessie, Hukum Perikatan. Perikatan Yang Lahir dari Perjanjian, Buku Kedua, Penerbit: Citra Aditya Bakti, Bandung,1995.

Soedarto, Hukum dan Hukum Pidana, Alumni, Bandung, 1977

Soerjono Soekanto, Pengantar Penelitian Hukum, Cetakan ketiga, Penerbit Universitas Indonesia, Jakarta, Indonesia, 1986.

Soerjono Soekanto dan Sri Mamudji, Penelitian Hukum Normatif, cetakan kelima, Raja Grafindo Perkasa, Jakarta, 2001.

Subekti, Aneka Perjanjian, PT Citra Aditya Bakti, Bandung, 1989 , Hukum Perjanjian, PT Intermasa, Jakarta, 1984

Aneka Perjanjian, PT Citra Aditya Bakti, Bandung, 1989

-, Kumpulan Karangan Hukum Perikatan Arbitrase dan pengadilan, (Bandung, Penerbit : Alumni, 1980).

, Pokok-Pokok Hukum Perdata, PT Intermasa, Jakarta, 1992.

Soedarto, Hukum dan Hukum Pidana, Alumni, Bandung, 1977.

Sudikno Mertokusumo, Penemuan Hukum Sebuah Pengantar, cetakan pertama, liberty, Yogyakarta, 2000.

Suyud Margono, "Alternatif Dispute Resolution dan Arbitrase," Cet XI; Bogor: Galia Indonesia, 1993 Takdir Rahmadi , Mediasi, Penyelesaian Penyelesaian Sengketa melalui Pendekatan Mufakat, Rajawali Pers, 2010

, Mekanisme alternatif Penyelesaian Sengketa Dalam Konteks Masyarakat Indonesia Masa Kini, makalah disajikan dalam Seminar Sehari Alternatif Penyelesaian Sengketa Dalam Kasus-Kasus Tanah, Perburuhan dan Lingkungan, Diselenggarakan Oleh Studi dan Advokasi Masyarakat bekerjasama dengan Dewan Pimpinan Pusat IKADIN, di Jakarta, 11 Agustus 1994

Tresna R, Komentar HIR, Pradnya Paramita , Jakarta :, 1975, hal. 130

Ziwar Effendi , Hukum Adat Ambon Lease, Pradnya Paramita, Jakarta, 1987. 